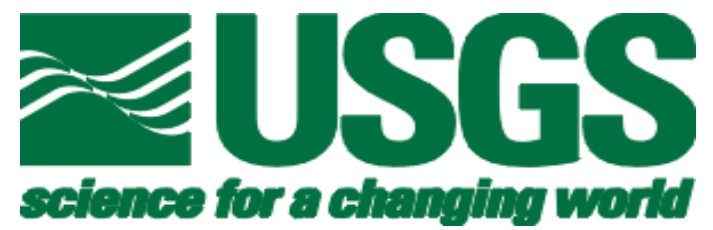

\title{
Measurements of Slope Current and Environmental Geochemistry near the Western Boundary of the Gulf of the Farallones National Marine Sanctuary
}

Marlene A. Noble, Jingping Xu, Jon Kolak, Anne L. Gartner, and Kurt Rosenberger

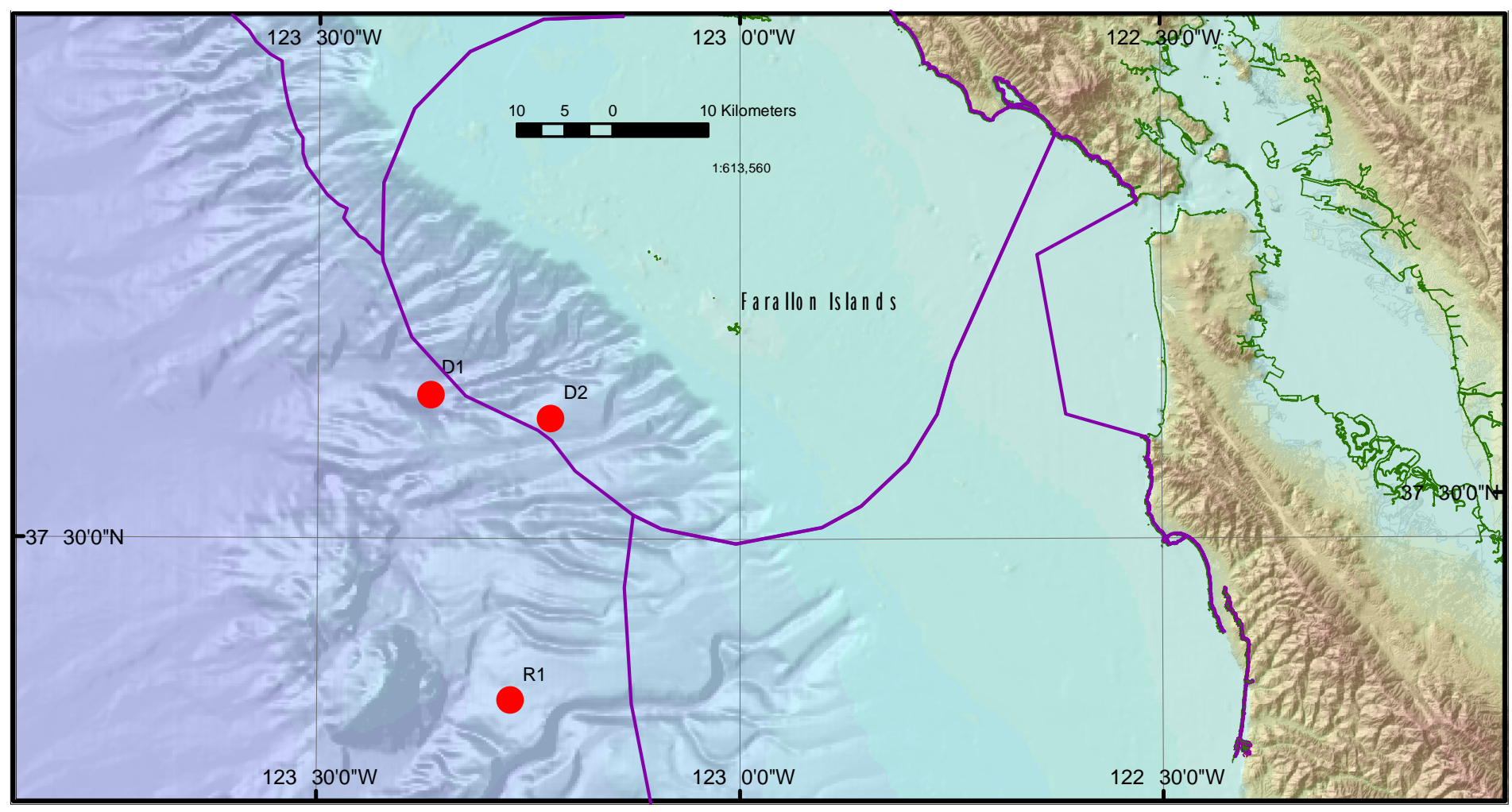

Open-File Report 2006-1288

Department of the Interior U.S. Geological Survey 


\section{U.S. Department of the Interior \\ Dirk Kempthorne, Secretary}

U.S. Geological Survey
Mark D. Myers, Director

U.S. Geological Survey, Menlo Park, California 2007

Open-File Report 2006-1288

\section{Measurements of Slope Current and EnvironmentalG eochemistry near the Western Boundary of the Gulf of the Farallones National Marine Sanctuary}

Marlene A. Noble ${ }^{1}$, Jingping $\mathrm{Xu}^{2}$, Jon Kolak ${ }^{3}$, Anne L. Gartner ${ }^{1}$, and Kurt J. Rosenberger $^{1}$

${ }^{1}$ U.S. Geological Survey, Menlo Park, Calif.

${ }^{2}$ U.S. Geological Survey, Santa Cruz, Calif.

${ }^{3}$ U.S. Geological Survey, Reston, Virg.

For product and ordering information:

World Wide Web: http://www.usgs.gov/pubprod

Telephone: 1-888-ASK-USGS

For more information on the USGS - the Federal source for science about the Earth,

its natural and living resources, natural hazards, and the environment:

World Wide Web: http://www.usgs.gov

Telephone: 1-888-ASK-USGS

Any use of trade, product, or firm names is for descriptive purposes only and does not imply endorsement by the U.S. Government.

Although this report is in the public domain, permission must be secured from the individual copyright owners to reproduce any copyrighted material contained within this report. 


\section{TABLE OF CONTENTS}

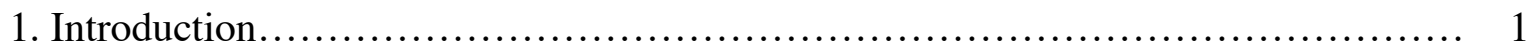

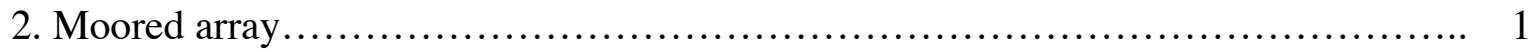

2.1 Mooring configuration............................................... 1

2.2 Sediment collection................................................ 8

2.3 Mussel collection and preservation ................................. 8

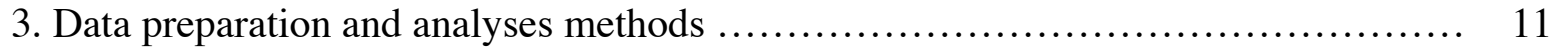

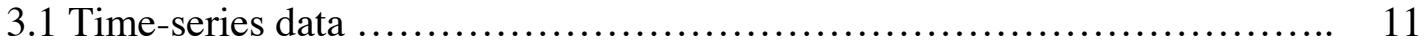

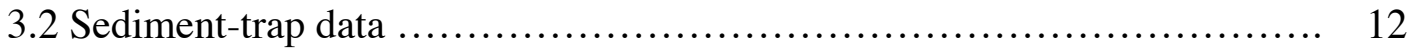

3.2.1 Grain-size analysis ..................................... 12

3.2.2 Organic/inorganic carbon analysis ........................... 13

3.2.3 Bulk percentage of organic matter analysis ..................... 13

3.3 Mussel tissue preparation ......................................... 13

3.4 Trace-metal analysis............................................ 14

3.4.1 Sediments.................................................. 14

3.4.2 Mussel tissue............................................. 14

3.5 Polynuclear Aromatic Hydrocarbons (PAH) analysis .................... 16

3.5.1 PAH extraction and analysis--mussel tissue ...................... 16

3.6 Quality Assurance/Quality Control (QA/QC) ....................... 17

4. Discussion.............................................................. 17

4.1 Spatial and temporal patterns seen in the current field over the slope........ 17

4.1.1 Mean current field................................................ 17

4.1.2 Subtidal current field............................................ 17

4.1.3 Tidal current field....................................... 27

4.2 Resuspension potential for sediments deposited on the slope.............. 32

4.3 Geological characteristics of material collected by the sediment traps ....... 36

4.4 Transport of suspended material by currents in this region of the slope..... 36

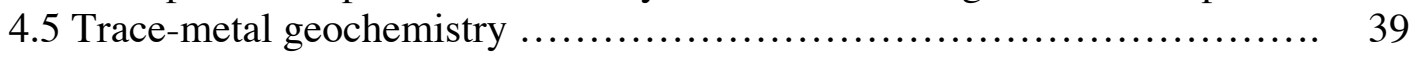

4.5.1 Trace-metal geochemistry-sediments.......................... 39

4.5.2 Trace-metal geochemistry-mussels........................... 41

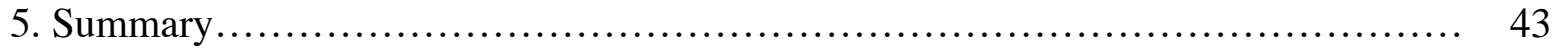

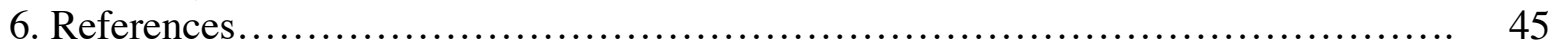

Appendix A. Hour-averaged currents

Appendix B. Hour-averaged low-pass-filtered currents

Appendix C. Subtidal current vectors

Appendix D. Variance-conserving plots

Appendix E. Temperature, salinity and transmission plots

Appendix F. Characteristics of tidal currents

Appendix G. Geochemistry of sediment-trap material and mussel tissue

Appendix H. Farallon Islands sediment-trap samples-Quality Assurance/Quality Control (QA/QC) Report 
This page intentionally left blank 


\section{INTRODUCTION}

For nearly a decade, dredged material from San Francisco Bay has been deposited at the U.S. Environmental Protection Agency (EPA) Region IX designated disposal site on the continental slope west of the Farallon Islands. Over the past several years, annual disposal volumes have ranged from $136,170 \mathrm{~m}^{3}$ (61 barge loads) to 2,407,600 $\mathrm{m}^{3}$ (1,173 barge loads) (Ota, personal communication, 2000). The EPA has conducted extensive studies to evaluate the fate and effects of the disposed material (Abdelrhman, 1992; Tetra-Tech, 1992; SAIC, 1992). The EPA has also maintained a long-term monitoring program to collect hydrodynamic, sedimentary, chemical, and biological data that are used to determine whether the dredged material adversely affects the ecology of adjacent water bodies and whether it moves from the disposal site, especially into the Gulf of the Farallones National Marine Sanctuary. As part of this monitoring program, the U.S. Geological Survey (USGS) Coastal and Marine Geology Program (CMGP) deployed arrays of instruments on three moorings near the EPA disposal site from November 1997 to November 1998. This report describes the results and findings of this field monitoring experiment.

\section{MOORED ARRAY}

\subsection{Mooring configuration}

In November 1997, three subsurface moorings were deployed on the continental slope (Moorings D1, D2, and R1) west of the Farallon Islands (Figure 1). The moored array was designed to monitor current velocity, water temperature, and several other physical properties of the water column for an entire year. The three mooring locations were selected to 1) monitor water-column properties and the amount of suspended material found near the disposal site (Mooring D1); 2) monitor these same processes at Mooring D2 in order to evaluate whether dredged material was transported into the Gulf of the Farallones National Marine Sanctuary, whose western boundary lies between Mooring D1 and D2; and 3) provide base values of measured parameters from reference site R1. All moorings were recovered in November 1998.

Instruments on the three moorings were similarly configured (Table 1; Figures 2a, b, c). Mooring D1 was deployed in 2404 m depth of water, just outside of the western boundary of the Gulf of the Farallones National Marine Sanctuary and about $10 \mathrm{~km}$ east of the EPA-designated disposal site. This mooring was deployed in the axis of a submarine canyon; the deep-water disposal site is located in the canyon fan. Mooring D1 had an an upward-looking ADCP at about $54 \mathrm{~m}$ below water surface, a SEACAT that measures the temperature and conductivity of the water at $55 \mathrm{~m}$, and 6 Aanderaa current meters at 179, 354, 754, 1254, 1954, and $2354 \mathrm{~m}$ (Table 1). In addition, Mooring D1 had three sediment traps at 174, 349, and $2394 \mathrm{~m}$, a bottom package comprised of current, temperature, conductivity, transmission sensors, and the sediment trap mentioned above that monitored oceanic processes at $10 \mathrm{~m}$ above bottom (mab) (2394 $\mathrm{m}$ ). Two mussel cages on this mooring monitored chemicals at 104 and $154 \mathrm{~m}$ below the surface. The lowest current meter on Mooring D1 was well below the rim of the canyon and the next lowest was near the canyon rim. Mooring D2 was deployed in $1190 \mathrm{~m}$ depth of water, about $15 \mathrm{~km}$ east of Mooring D1, and inside the sanctuary. It had essentially the same type of equipment as Mooring D1, except that the ADCP was replaced with a vector-averaging current meter (VACM) 


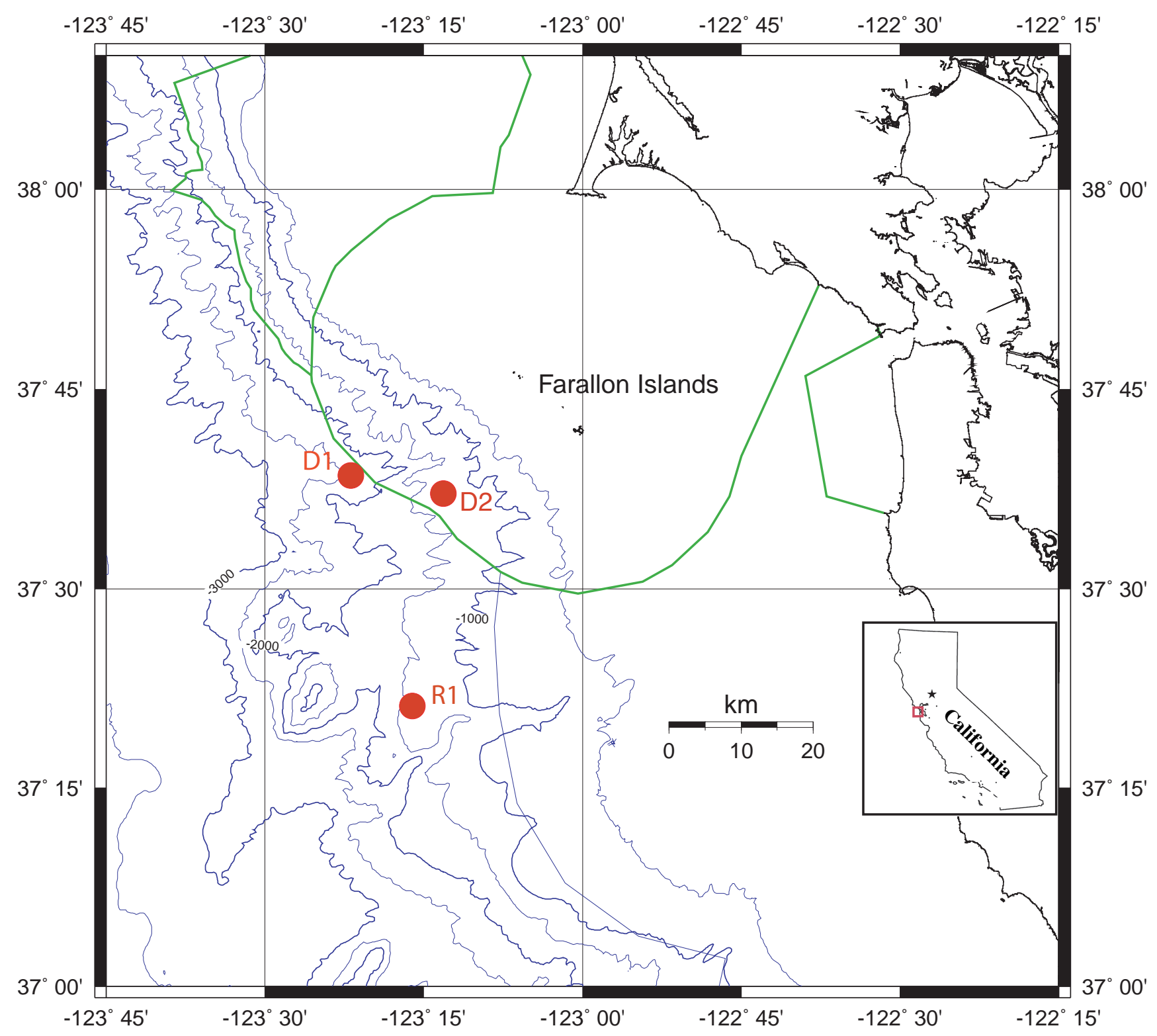

Figure 1. Locations of the three moorings. Borders in green indicate boundaries of Gulf of the Farallones National Marine Sanctuary. 
Table 1. Data availability for Moorings D1, D2, and R1. For the ADCPs at Moorings D1 and R1, the bins were $4 \mathrm{~m}$ and $2 \mathrm{~m}$ thick, respectively. The depth of the middle of the lowest bin for Mooring D1 was $46 \mathrm{~m}$; the highest valid bin was $6 \mathrm{~m}$. The depth of the middle of the lowest bin for Mooring R1 was 82; the highest valid bin was $6 \mathrm{~m}$. The bottom package on the moorings is a VACM-TCT, which measures current, temperature, conductivity, and water clarity, and contains a sediment trap. Salinity at the various sites is calculated using measured temperature and conductivity records.

\begin{tabular}{|c|c|c|c|c|c|c|c|}
\hline $\begin{array}{c}\text { Mooring } \\
\text { ID }\end{array}$ & $\begin{array}{c}\text { Water } \\
\text { Depth } \\
\text { (m) }\end{array}$ & $\begin{array}{c}\text { Latitude } \\
\text { Longitude }\end{array}$ & $\begin{array}{c}\text { Instrument } \\
\text { Type }\end{array}$ & Frequency & $\begin{array}{c}\text { Actual } \\
\text { Instrument } \\
\text { Depth } \\
\text { (m) }\end{array}$ & $\begin{array}{l}\text { Variables } \\
\text { Measured }\end{array}$ & $\begin{array}{c}\text { Raw } \\
\text { Electronic } \\
\text { File } \\
\text { Name } \\
\end{array}$ \\
\hline \multirow[t]{13}{*}{ 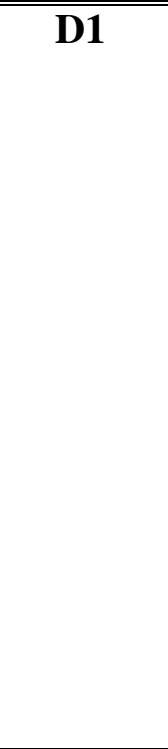 } & \multirow[t]{13}{*}{2404} & \multirow{13}{*}{$\begin{array}{l}37^{\circ} 38.6 \mathrm{~N}, \\
123^{\circ} 21.9 \mathrm{~W}\end{array}$} & ADCP & $30 \mathrm{~min}$ & 54 & VWv & EPAD1adcp \\
\hline & & & Seacat & $15 \mathrm{~min}$ & 55 & TCS Sig & $5102 \mathrm{sc}-\mathrm{a}$ \\
\hline & & & Mussel cages & & 104 & Cages & No File \\
\hline & & & Mussel cages & & 154 & Cages & No File \\
\hline & & & Sediment trap & & 174 & SedTrap & No Fiile \\
\hline & & & Aanderaa cm & $20 \mathrm{~min}$ & 179 & TPV & $5103-a$ \\
\hline & & & Sediment trap & & 349 & SedTrap & No File \\
\hline & & & Aanderaa cm & $20 \mathrm{~min}$ & 354 & TPV & 5104-a \\
\hline & & & Aanderaa $\mathrm{cm}$ & $60 \mathrm{~min}$ & 754 & TPV & $5105-a$ \\
\hline & & & Aanderaa $\mathrm{cm}$ & $60 \mathrm{~min}$ & 1254 & TPV & 5106-a \\
\hline & & & Aanderaa cm & $60 \mathrm{~min}$ & 1954 & TV & $5107-a$ \\
\hline & & & Aanderaa $\mathrm{cm}$ & $60 \mathrm{~min}$ & 2354 & TV & 5108-a \\
\hline & & & Bottom package & $15 \mathrm{~min}$ & $\begin{array}{l}2394 \\
2394 \\
2394 \\
\end{array}$ & $\begin{array}{l}\text { TV } \\
\text { TatTr } \\
\text { CS } \\
\end{array}$ & $\begin{array}{l}5109-\mathrm{a} \\
5109 \text { att-a } \\
5109 \mathrm{cs}-\mathrm{a} \\
\end{array}$ \\
\hline \multirow[t]{9}{*}{$\overline{\mathrm{D} 2}$} & \multirow[t]{9}{*}{1190} & \multirow[t]{9}{*}{$\begin{array}{l}37^{\circ} 37.2 \mathrm{~N}, \\
123^{\circ} 13.2 \mathrm{~W}\end{array}$} & VACM-TCT & $15 \mathrm{~min}$ & $\begin{array}{l}90 \\
90 \\
\end{array}$ & $\begin{array}{l}\text { TV } \\
\text { CS } \\
\end{array}$ & $\begin{array}{l}5111-\mathrm{a} \\
5111-\mathrm{cs} \\
\end{array}$ \\
\hline & & & Mussel cages & & 140 & Cages & No File \\
\hline & & & Sediment trap & & 210 & SedTrap & No File \\
\hline & & & Aanderaa cm & $20 \mathrm{~min}$ & 215 & TPV & $5112-\mathrm{a}$ \\
\hline & & & Sediment trap & & 385 & SedTrap & No File \\
\hline & & & Aanderaa cm & $20 \mathrm{~min}$ & 390 & TPV & 5113-a \\
\hline & & & Aanderaa $\mathrm{cm}$ & $60 \mathrm{~min}$ & 790 & TPV & 5114-a \\
\hline & & & Aanderaa cm & $60 \mathrm{~min}$ & 1140 & TPV & $5115-a$ \\
\hline & & & Bottom package & $15 \mathrm{~min}$ & $\begin{array}{l}1180 \\
1180 \\
1180\end{array}$ & $\begin{array}{l}\text { TV } \\
\text { TatTr } \\
\text { CS }\end{array}$ & $\begin{array}{l}5116-\mathrm{a} \\
5116 \mathrm{att}-\mathrm{a} \\
5116 \mathrm{cs}-\mathrm{a}\end{array}$ \\
\hline
\end{tabular}


Table 1, cont.

\begin{tabular}{|c|c|c|c|c|c|c|c|}
\hline $\begin{array}{l}\text { Mooring } \\
\text { ID }\end{array}$ & $\begin{array}{c}\text { Water } \\
\text { Depth } \\
\text { (m) }\end{array}$ & $\begin{array}{c}\text { Latitude } \\
\text { Longitude }\end{array}$ & $\begin{array}{c}\text { Instrument } \\
\text { Type }\end{array}$ & Frequency & $\begin{array}{c}\text { Actual } \\
\text { Instrument } \\
\text { Depth } \\
\text { (m) }\end{array}$ & $\begin{array}{l}\text { Variables } \\
\text { Measured }\end{array}$ & $\begin{array}{c}\text { Raw } \\
\text { Electronic } \\
\text { File } \\
\text { Name }\end{array}$ \\
\hline \multirow[t]{11}{*}{ R1 } & \multirow[t]{11}{*}{1387} & \multirow{11}{*}{$\begin{array}{l}37^{\circ} 21.2 \mathrm{~N}, \\
123^{\circ} 16.1 \mathrm{~W}\end{array}$} & ADCP & $60 \mathrm{~min}$ & 87 & TV SeaLev & $5121 \mathrm{wh} 2 \mathrm{~T}$ \\
\hline & & & Seacat & $15 \mathrm{~min}$ & 88 & TCS SigT & $5122 \mathrm{sc}-\mathrm{a}$ \\
\hline & & & Mussel cages & & 137 & Cages & No File \\
\hline & & & Mussel cages & & 187 & Cages & No File \\
\hline & & & Sediment trap & & 207 & SedTrap & No File \\
\hline & & & Aanderaa cm & $20 \mathrm{~min}$ & 212 & TPV & $5123-\mathrm{a}$ \\
\hline & & & Sediment trap & & 382 & SedTrap & No File \\
\hline & & & Aanderaa cm & $60 \mathrm{~min}$ & 387 & TPV & $5124-q$ \\
\hline & & & Aanderaa cm & $60 \mathrm{~min}$ & 787 & TPV & $5125-\mathrm{a}$ \\
\hline & & & Aanderaa cm & $60 \mathrm{~min}$ & 1337 & TPV & 5126-a \\
\hline & & & Bottom package & $15 \min$ & $\begin{array}{l}1377 \\
1377 \\
1377\end{array}$ & $\begin{array}{l}\text { TV } \\
\text { TatTr } \\
\text { CS }\end{array}$ & $\begin{array}{l}5127-\mathrm{a} \\
5127 \text { att-a } \\
5127 \mathrm{cs}-\mathrm{a}\end{array}$ \\
\hline
\end{tabular}

$\mathrm{V}=$ horizontal velocity

$\mathrm{W}=$ vertical velocity

$\mathrm{T}=$ temperature

$\mathrm{C}=$ conductivity

$\mathrm{S}=$ salinity

Sig= density

$\mathrm{P}=$ pressure

$\mathrm{TR}=\mathrm{t}$ ransmission

at $=$ attenuation 


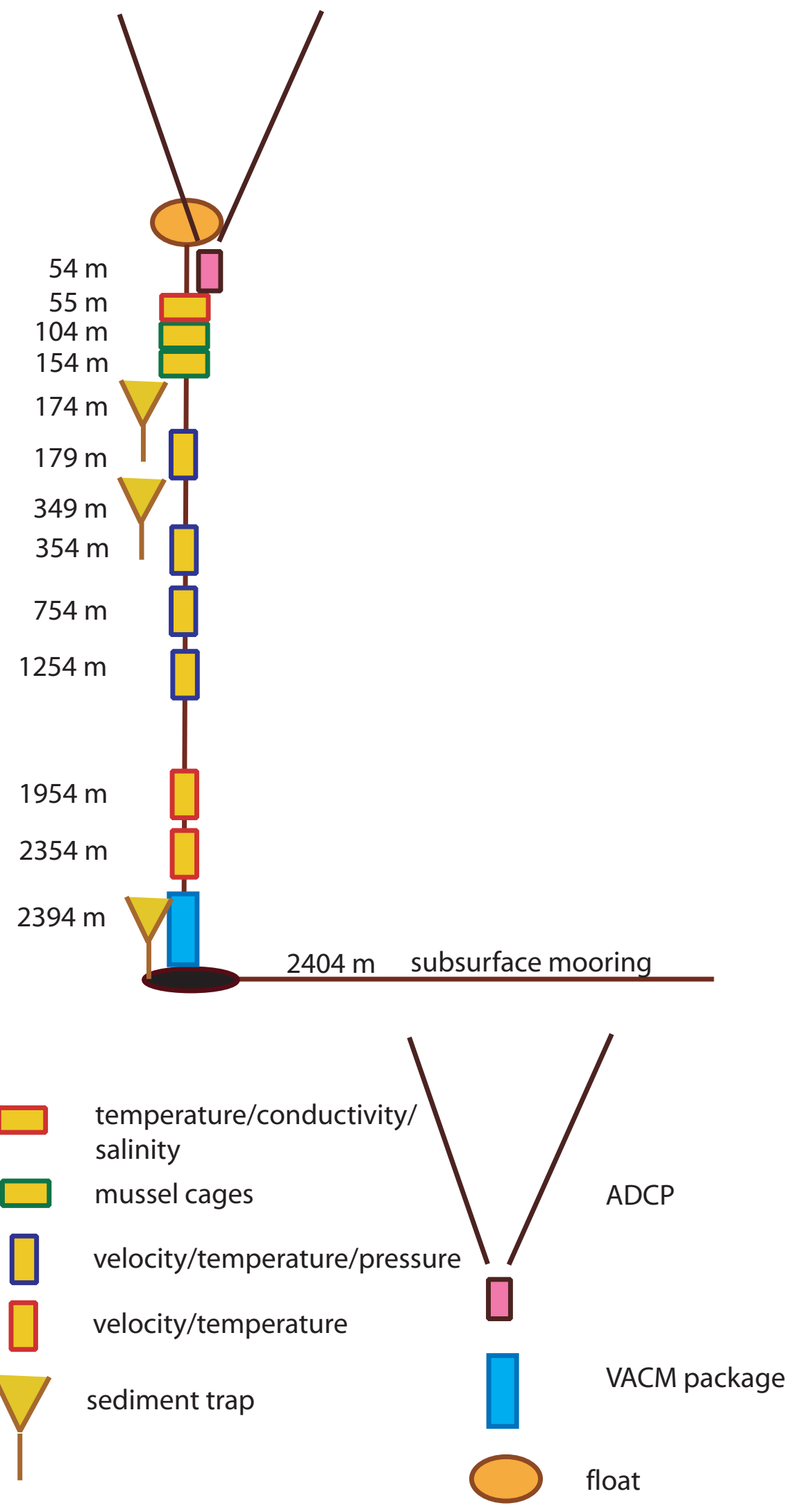

Figure 2a. Schematic diagram of subsurface mooring at Mooring D1. 

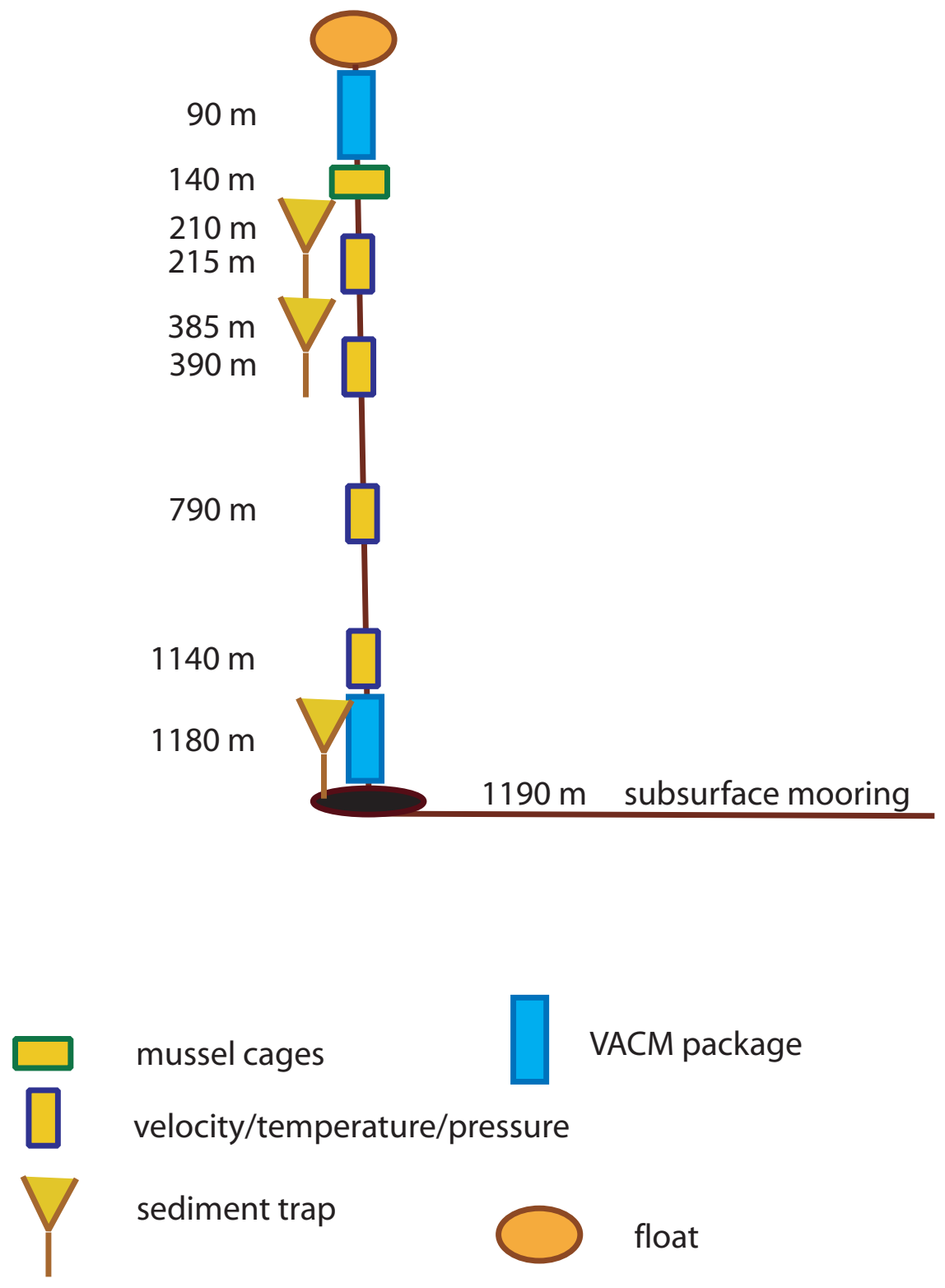

Figure 2b. Schematic diagram of subsurface mooring at Mooring D2. 

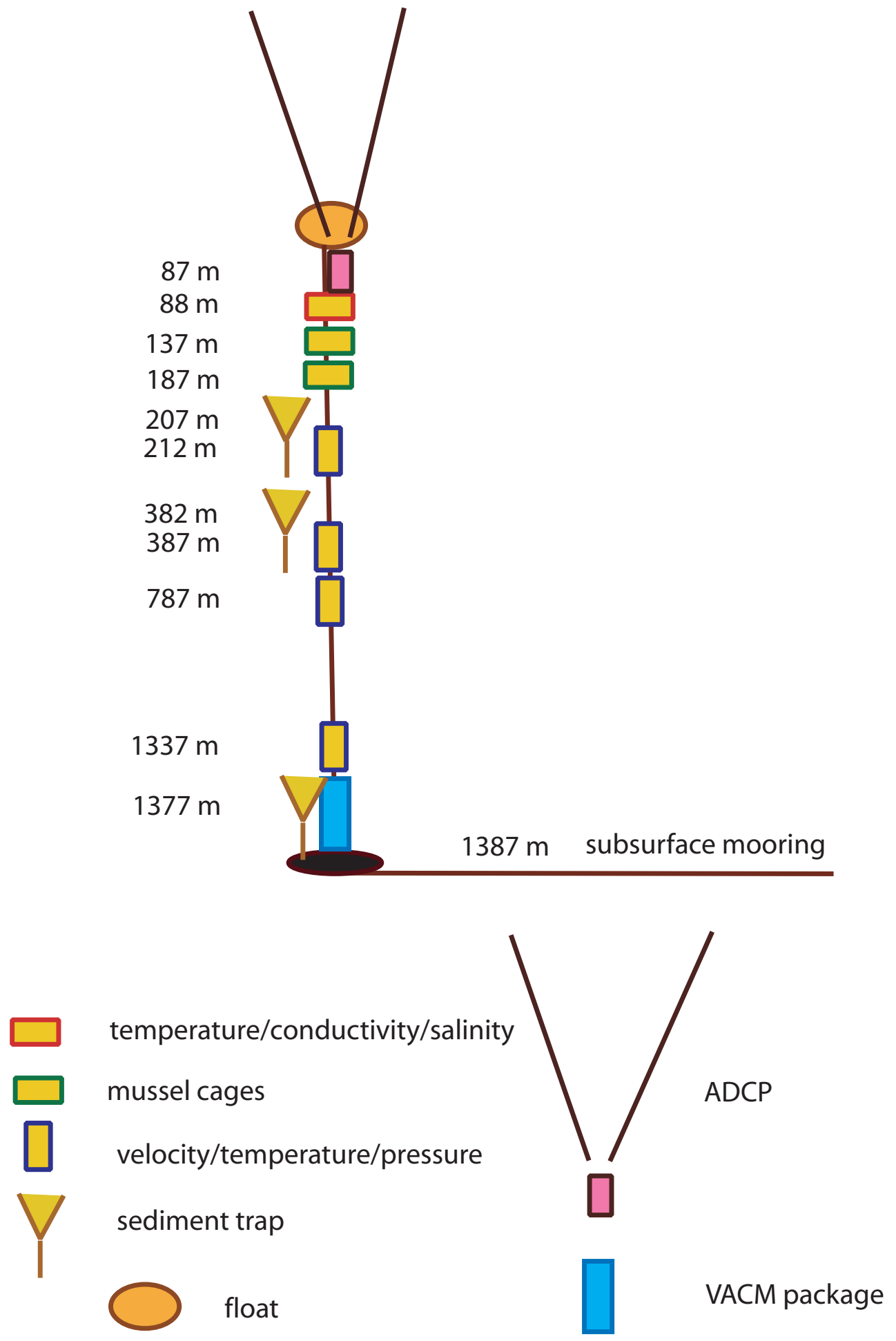

Figure 2c. Schematic diagram of subsurface mooring at Mooring R1. 
that measured current, temperature, and conductivity at $90 \mathrm{~m}$ below the surface. Because the mooring was shorter, there were only four Aanderaa current meters between the surface and the bottom package at 10 mab and only one mussel cage. The reference mooring, R1, was deployed in $1387 \mathrm{~m}$ depth of water. It was located about $30 \mathrm{~km}$ south of Mooring D1 at a site previously occupied by a larger EPA-supported array deployed in 1991 (named Site D in the previous array). Data from this mooring is presumably unaffected by activities at the disposal site. Mooring R1 carried the same instruments as Mooring D1, except that the upward-looking ADCP was located $87 \mathrm{~m}$ below the surface. Table 1 lists the sampling frequencies of all time-series data.

\subsection{Sediment collection}

The sediment traps on the moorings had a 50-cm-diameter, 100-cm-long baffled collecting funnel attached to a collection tube $70 \mathrm{~cm}$ long and $5 \mathrm{~cm}$ in diameter. The traps collected sediment continuously, and a device inside the traps dispensed a small amount of white Teflon ${ }^{\circledR}$ beads at 21-day intervals to provide "time marks." Another dispenser released poison (sodium azide) to the collection tube to minimize organic growth during the deployment.

Seven of the nine sediment traps deployed on the three moorings were successfully recovered (Figure 3a). Four of these seven sediment traps provided enough material to be analyzed. The traps that collected the most material were on Mooring D1, the site nearest the disposal site (Figure 3b). The volume of the collected material in three traps (mid-depth (385 m) on Mooring D2 and both the recovered traps on Mooring R1) was negligible. The material collected in the bottom traps on Moorings D2 and R1 were lost during recovery when they became entangled and inverted.

\subsection{Mussel collection and preservation}

The mussels (Mytilus californianus) attached to the moorings were collected from Bodega Head. Mussels from this locale are routinely analyzed for background contaminants and are standardly used to monitor chemicals or pollutants in the environment (see http://www.swrcb.ca.gov). The mussels were pried off rocks with dive knives. Collected mussels were carried out in cleaned nylon daypacks. About 50 mussels, 55 to $65 \mathrm{~mm}$ in length, were then placed in individual polypropylene mesh bags in preparation for deployment on the moorings. The mussels in the mesh bags $(76 \mathrm{~mm} \times 13 \mathrm{~mm})$ were subdivided into three groups of approximately equal size and sectioned with cable ties. Each bag represents a trace metal (TM) or organic (SO) sample. The bags were stored cold for no more than 48 hours before they were deployed with the moorings. The sample bags were attached with cable ties to the mooring line about 100 and $150 \mathrm{~m}$ below the water surface (Table 1). Upon retrieval at the moorings, the mussels designated for TM were placed into labeled polyethylene bags (4-mm thickness). All SO mussels were transferred from the moorings into cleaned aluminum-foil bags. Both sets of samples were stored in non-metallic ice chests and frozen using dry ice or regular ice. At the lab, samples were preserved in a cold room (at or below $20^{\circ} \mathrm{C}$ ) until analyzed. 


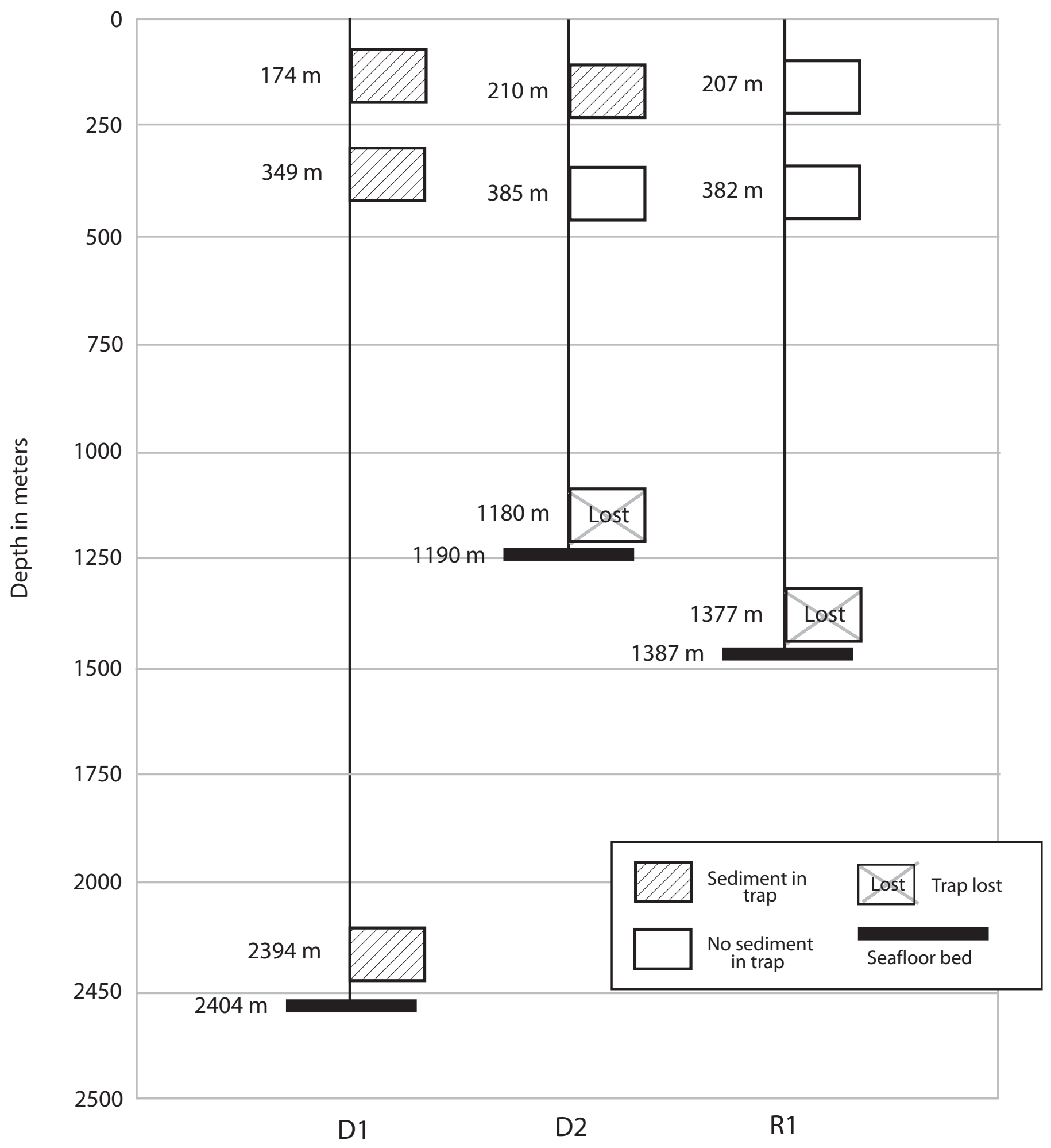

Figure 3a. Depths and recovery rates of sediment traps from each mooring. 


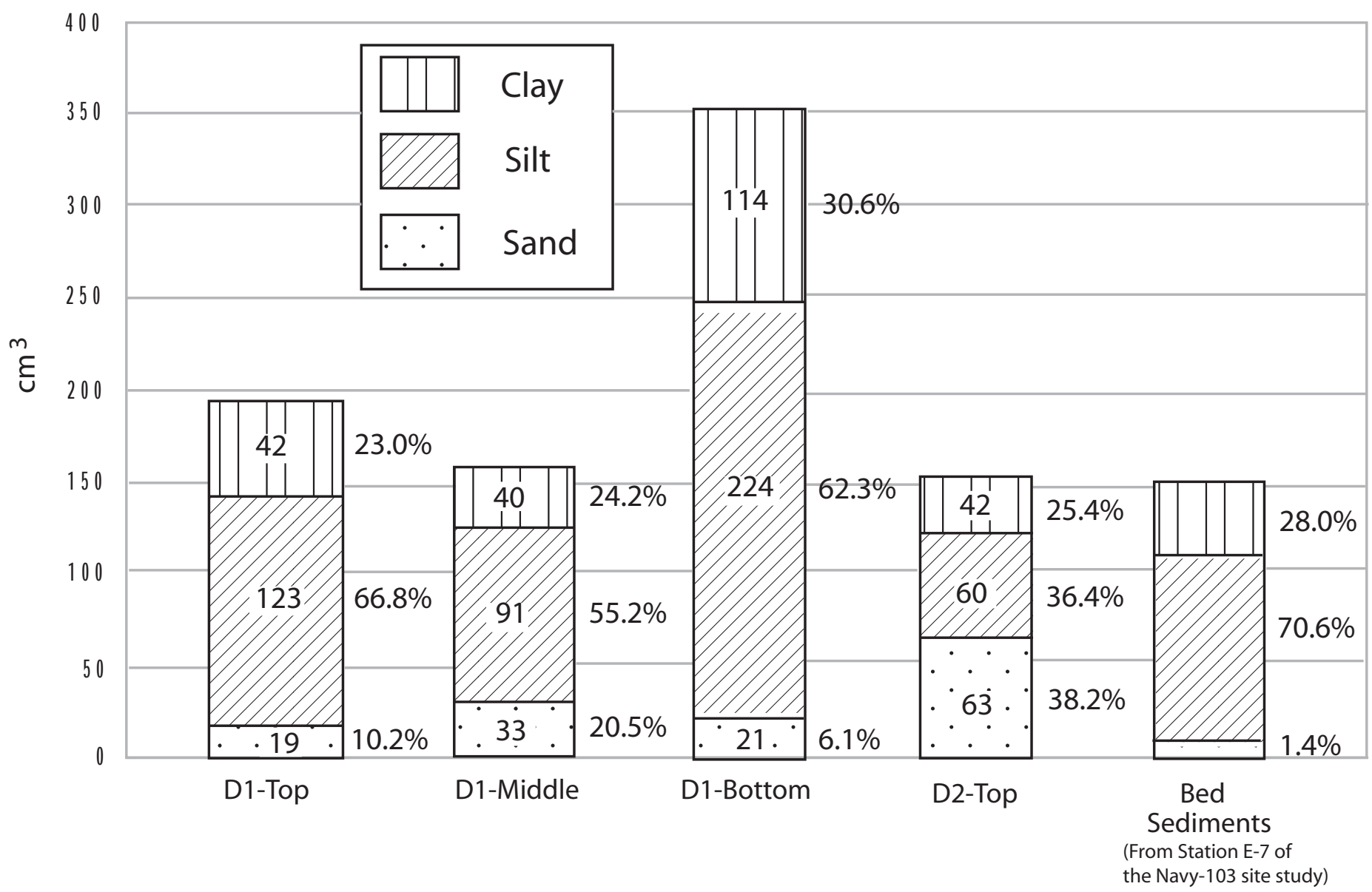

Figure 3b. Volumes of sediment collected in four sediment traps. The numbers in the stacked columns are the volumes (in $\mathrm{cm}^{3}$ ) of three size classes: clay, silt, and sand. The percentages of each size class are also shown. 


\section{DATA PREPARATION AND ANALYSES METHODS}

\subsection{Time-series data}

The time-series data from individual instruments were downloaded, transcribed into scientific units, and then passed through several quality-control steps. The data were checked for errors caused by instrument failures. Obvious spikes and gaps were removed from the data. Greenwich mean time (GMT) is the common timebase for all data records.

There were short temporal gaps in many of the data records. Gaps of less than 30 minutes were linearly interpolated. Gaps of a few hours to a few days were spectrally filled using a Joseph Scheme that uses the frequency properties of the data adjacent to the gap to generate the interpolated data (Anderson, 1974). Longer gaps were not filled.

The very-near surface current data measured by the ADCPs were removed from the current-meter files due to obvious measurement errors. Hence, the shallowest currents measured at Moorings D1 and R1 were 3.3 and $3.9 \mathrm{~m}$ below the surface, respectively.

The basic current records with sampling frequencies of less than an hour were averaged into hourly records to create a common sampling frequency for the entire data set. These records were used for the basic statistics reported here and for the tidal analyses. These records were also low-pass filtered (filter PL33) (Limeburner, 1985); hence the tides were removed from the current records. These low-pass filtered records will be called subtidal records in this report.

The subtidal currents were rotated into a coordinate system that is aligned with, or perpendicular to, the slope isobaths or canyon axis. For most sites, the positive along-slope direction is $320^{\circ}$, toward the northwest, and the positive cross-slope direction is $50^{\circ}$, toward the coast. For the lowest two current meters at Mooring D1, which are near or below the canyon rim, currents were also rotated parallel to the canyon axis; the positive along-canyon direction is $100^{\circ}$ (up-canyon), and the positive cross-canyon direction is $190^{\circ}$.

Several statistical quantities are discussed in this report; i.e., the mean, and the standard deviation of various measured quantities. The error bars around the mean values indicate the stability of that mean value. In order for a mean current direction to be reliable, the mean values must be greater than the error bar. Otherwise, the mean directions are not significantly different from zero.

The formula for the error bar around the mean is

$$
\frac{\sigma t_{n ; \alpha / 2}}{\sqrt{n+1}}
$$

where $\sigma$ is the standard deviation of the subtidal data, $(n+1)$ is the degrees of freedom in that data, and $t$ is the student $t$ statistic at the 100(1- $\alpha)$ percent confidence limit. The degrees of freedom is the record length divided by the auto-correlation scale of the subtidal data set.

The tidal analysis is the result of performing a least-squares fit of the observed data records to amplitudes and phases of specific tidal frequencies that are derived from the motions of the sun and moon. The methods are given in Godin (1972), and the implementation uses the programs written by Foreman $(1977 ; 1978)$. The major constituents of interest are grouped into two frequency bands; the semidiurnal $\left(\mathrm{M}_{2}, \mathrm{~S}_{2}\right)$ and diurnal $\left(\mathrm{K}_{1}, \mathrm{O}_{1}\right)$. Tidal-current amplitudes were computed for all currents in the array, including currents measured at each bin of the two ADCPs. Because Mooring D2 had only a single current record near the surface, tidal current 
amplitude from the lowest bin of each ADCP are used to compare amplitudes among the three mooring sites.

Instruments on the moorings also measured the temperature and conductivity of seawater (Appendix E). Temperature was measured in degrees Centigrade. Both the temperature and conductivity were used to calculate the salinity of seawater. Using standard oceanographic formula (UNESCO, 1991), salinity is reported in practical salinity units.

The hour-averaged transmissometer measurements (transmission) were converted to beam attenuation using the formula

$$
\mathrm{c}=-\left(\ln \left[\mathrm{T}_{\mathrm{r}} / \mathrm{T}_{0}\right]\right) / \mathrm{L}
$$

where $T_{r}$ is measured transmission in voltage, $T_{0}$ is transmission voltage through clear water, $L$ is the path length of the transmissometer $\left(0.25 \mathrm{~m}\right.$ in this case), and $\mathrm{c}$ is attenuation in $\mathrm{m}^{-1}$.

\section{2 $\underline{\text { Sediment-trap data }}$}

Sediments were successfully recovered from four of the sediment traps: Mooring D1 top, middle, and bottom, and Mooring D2, top. Insufficient amounts of sediment had accumulated in the Mooring D2 middle trap and the top two traps on Mooring R1 to facilitate analyses.

Following retrieval, the texture, stratigraphy, and color of the accumulated sediments were visually described and recorded. The sediments in the bottom trap on Mooring D1 were slightly packed. Sediments accumulated in the other three traps were fluffy with high water content. The total volume of sediment collected in each trap (Figure 3b) was measured. Cumulative and timeinterval sediment accumulation volumes were calculated based on the uniform sediment-trap tube diameter of five $\mathrm{cm}$.

After the standing water was removed from the sediment-trap tubes, the sediment was mechanically extruded from the tubes. Subsamples of extruded sediment were transferred to precleaned glass jars with acid-washed Teflon ${ }^{\circledR}$ spatulas and then frozen. The stratigraphy was well preserved (i.e., discrete bands of Teflon $\AA$ beads were present) in the sediment column that had accumulated within the Mooring D1 bottom trap. As a result, multiple samples (D1B-1, D1B-2, and D1B-3) were collected from this trap.

Sediment samples were later thawed and aliquots removed for bulk organic matter, grain size, total organic carbon (TOC) and trace-metal analyses. These thawed aliquots were wetsieved through acid-washed, nylon mesh $(63-\mu \mathrm{m}$ diameter) with distilled, deionized water (DDW) in order to remove the Teflon ${ }^{\circledR}$ beads. Aliquots of sieved sediment were removed for bulk organic matter and grain-size analyses. The remaining sieved material was dried in a forced-air convection oven at $40^{\circ} \mathrm{C}$ until the sample mass stabilized (generally 24 hours). These dried sediment samples were homogenized using a ceramic mortar and pestle, and then stored in acid-washed polypropylene bottles for trace metal extraction and organic carbon analysis.

\subsubsection{Grain-size analysis}

Grain sizes were analyzed in a Coulter LS particle-size analyzer whose range was set to 0.4-1000 $\mu \mathrm{m}$ (from fine clay to very coarse sand). Commonly used protocols for organic-matter oxidization and salt removal were followed in sample preparation. At least three replicates from 
each sample were analyzed. The averages from these replicates were then regrouped into sand, silt, and clay-size classes.

\subsubsection{Organic/inorganic carbon analysis}

Total carbon (TC) and total inorganic carbon (TIC) were determined by coulometric titration on a CM $5012 \mathrm{CO}_{2}$ Coulometer (UIC Coulometrics, Inc., Joliet, IL), coupled to an acidification module and furnace apparatus. TC and TIC analyses were conducted separately on sediment samples. TC content was measured by combusting a sample $(\sim 20 \mathrm{mg})$ in a furnace preheated to $1000^{\circ} \mathrm{C}$ until no more $\mathrm{CO}_{2}$ was evolved ( five minutes). TIC content was measured by a heated perchloric acid digestion until no more $\mathrm{CO}_{2}$ was evolved ( $\sim$ five minutes). TOC content in sediments was determined by calculating the difference between these two quantities.

\subsubsection{Bulk percentage of organic matter analysis}

To determine the amount of organic matter in each sample, wet samples were first dried in an oven at $55^{\circ} \mathrm{C}$ for two days to remove moisture. The weighed dry samples were then baked in a furnace of $500^{\circ} \mathrm{C}$ for two hours to burn all organic contents in the samples. The organic percentage was then calculated from the difference in weight between the pre- and post-baked samples.

\subsection{Mussel tissue preparation}

All laboratory processing (dissecting, homogenizing, and digesting/extracting) was carried out under "clean room" conditions (criteria enumerated in Flegal (1982) are recommended), with a positive-pressure, filtered air supply, non-contaminating laboratory surfaces, and a supply of de-ionized and Type II water (MilliQ). In the laboratory, 45 mussels were dissected per sample and split into 3 groups of 15 mussels each. The three groups created $\mathrm{A}, \mathrm{B}$, and $\mathrm{C}$ replicates. If there were fewer than 45 mussels in the sample, the mussels were divided into 3 equal groups. The total number of mussels in each jar was noted. The adductor muscles were severed with a scalpel and the mussel pried open with the plastic end of the scalpel. The gonads were then removed. The gonads from the first 15 mussels were placed in a tared container and weighed. These and all subsequent gonads were then thrown away. The byssal threads were removed. The remainder of the soft part was removed from the shell and placed in a pre-weighed, acid-cleaned, polypropylene $125-\mathrm{mL}$ jar.

For trace-metal analysis of the tissue, the samples were homogenized in $125-\mathrm{mL}$ polyethylene jars, using a Brinkmann Polytron (model PT10-35) equipped with a titanium generator (model PTA 20). For organic analysis of the tissue, the samples were homogenized in the 500-mL glass jars into which they were dissected. As with the metals homogenization, the Brinkmann Polytron was used. In both instances, the tissue was homogenized to a paste-like consistency; no chunks of clearly defined tissue were left in the homogenate. Following homogenization, both TM and SO samples were refrozen at $-20^{\circ} \mathrm{C}$ until digested/extracted. 


\subsection{Trace-metal analysis}

\subsubsection{Sediments}

Sediment samples were digested and analyzed for trace-metal content at the ICP-HEXMS Laboratory at Michigan State University (East Lansing, MI). Sediment digestions were conducted using a modified version of EPA Method 3051, "Microwave-Assisted Acid Digestion of Sediments, Sludges, Soils, and Oils," Approximately $0.500 \mathrm{~g}$ of dried, homogenized sediment was weighed into a fluorocarbon digestion vessel, to which $10 \mathrm{~mL}$ of concentrated $(15 \mathrm{M})$ trace metal-free nitric acid was added. One method blank was processed with each suite of digestion vessels to monitor for contamination. All vessels were placed in a CEM MDS 81d microwave unit (CEM Corporation; Matthews, NC) and heated for 15 minutes. Vessels were not opened until internal vessel pressure had dropped to ambient levels. Pre- and post-digestion vessel weights were measured (to $0.001 \mathrm{~g}$ ) to monitor for sample loss.

Once cooled, the vessels were opened and the digestate was diluted with $20 \mathrm{~mL}$ of distilled, de-ionized water. Digestates were then homogenized, filtered through acid-rinsed polycarbonate filters $(0.4 \mu \mathrm{m}$ pore diameter), and stored in acid-washed polypropylene bottles at $4^{\circ} \mathrm{C}$ until analysis. Digestate samples were analyzed for a suite of 21 trace metals using a modified version of EPA Method 6020, "Inductively Coupled Plasma-Mass Spectrometry." Iron and aluminum concentrations in the digestates were measured using flame atomic absorption. All sample analyses were completed within 30 days of the digestion.

\subsubsection{Mussel tissue}

An acid-pressure digestion in a closed Teflon ${ }^{\circledR}$ vessel was used for the determination of the following elements in the mussel tissue: aluminum (Al); antimony (Sb); arsenic (As); barium (Ba); cadmium $(\mathrm{Cd})$; chromium $(\mathrm{Cr})$; copper $(\mathrm{Cu})$; iron $(\mathrm{Fe})$; lead $(\mathrm{Pb})$; manganese $(\mathrm{Mn})$; mercury (Hg); nickel (Ni); selenium (Se); silver (Ag); strontium (SR); tin (Sn); vanadium (V); and zinc (Zn). Digestates were analyzed by Inductive Coupling Plasma Mass Spectrophotometer (ICP-MS), Flow Injection Mercury System (FIMS), Low-Level Mercury Detection System (LLMDS), flame (FAAS) and graphite furnace (GFAAS) atomic absorption spectrophotometry. Detection limits for these quantities are listed in Table 3.

The tissue samples were prepared for analysis by digesting with concentrated 4:1 nitric:perchloric acid in a Teflon ${ }^{\circledR}$ vessel. Tissue samples were first heated on hot plates for five hours. Then, vessel caps were tightened and the vessels heated in a vented oven at $130^{\circ} \mathrm{C}$ for four hours. The liquid digestate was poured into pre-weighed polyethylene bottles, then diluted with Type II water (MilliQ) to a final volume of $20.0 \mathrm{~mL}$.

Pre-cleaned plastic knives were used to aliquot $3 \pm 0.10 \mathrm{~g}$ of homogenized tissue or 0.50 $\pm 0.02 \mathrm{~g}$ of an appropriate standard reference material (SRM) into pre-weighed Teflon ${ }^{\circledR}$ vessels. The Teflon ${ }^{\circledR}$ vessel was re-weighed, and the total weight of both vessel and sample was recorded. Each sample was also aliquoted to a drying dish for moisture determination. Its initial weight was recorded, then $3 \pm 0.10 \mathrm{~g}$ of tissue were aliquoted into it. The wet weight was recorded. All of the drying dishes were placed on oven racks, then dried for 48 hours in a VWR oven at $72^{\circ} \mathrm{C}$. The final dry weights were recorded. Three $\mathrm{mL}$ of $4: 1 \mathrm{HNO}_{3}: \mathrm{HClO}_{4}$ was added to each vessel, and the caps were hand-tightened. Spiked samples got the following: 
Spike 1: $\quad 100 \mu \mathrm{L} 100 \%$ spike solution $100 \mu \mathrm{L} 1000 \mathrm{ppm}$ Fe standard solution $100 \mu \mathrm{L} 1000 \mathrm{ppm} \mathrm{Zn}$ standard solution

Spike 2: $\quad 100 \mu \mathrm{L} 10 \%$ spike solution

$100 \mu \mathrm{L} 2 \mathrm{ppm} \mathrm{Hg}$ standard solution

The vessels were placed on a warm $\left(75^{\circ} \mathrm{C}\right)$ hotplate under the hood for five hours to let the nitric fumes vent in the hood prior to placement in the oven. Because hotplates often do not heat evenly, the Teflon ${ }^{\circledR}$ vessels were rotated around the hotplate every half-hour, and removed from the hotplate. The caps were tightened with a CEM Capping Station, then placed in the oven for four hours at $130^{\circ} \mathrm{C}$. The oven was turned off, the vessels allowed to cool, and then uncapped under the hood with the capping station. Each vessel was allowed to fume, then approximately $15 \mathrm{~mL}$ of MilliQ was added. The vessels were capped hand-tight, then lightly shaken to mix in the water. The solution was then transferred to the corresponding pre-weighed $30-\mathrm{mL}$ polyethylene sample bottle. The final solution was brought up to a total final weight of $20 \mathrm{~g}$ with MilliQ. Tissue and sediment digestates are analyzed by ICP-MS for Ag, Al, As, Cd, Cr, Cu, Mn, $\mathrm{Ni}, \mathrm{Pb}, \mathrm{Se}$, and $\mathrm{Zn}$.

Table 2. Detection limits for determination of elements in mussel tissue (concentrations in $\mathrm{mg} / \mathrm{g}$ dry weight).

\begin{tabular}{||c|c||}
\hline Element & Tissue (3-g sample weight) \\
\hline \hline Aluminum & 1.0 \\
Antimony & 0.10 \\
Arsenic & 0.25 \\
Cadmium & 0.01 \\
Chromium & 0.10 \\
Copper & 0.10 \\
Iron & 0.10 \\
Lead & 0.10 \\
Manganese & 0.050 \\
Mercury & 0.030 \\
Nickel & 0.10 \\
Selenium & 0.010 \\
Silver & 0.010 \\
Tin & 0.020 \\
Zinc & 0.050 \\
TBT & 0.020 \\
\hline
\end{tabular}


3.5 Polynuclear Aromatic Hydrocarbons (PAH) analysis

\subsubsection{PAH extraction and analysis--mussel tissue}

The U.S. Fish and Wildlife Service uses these methods to determine synthetic organics and PAH in tissue samples. These procedures are applicable when low part-per-billion analyses are required to monitor differences between burdens in organisms from relatively uncontaminated reference areas and contaminated areas. In addition, the procedures are applicable when low detection limits are required for the estimation of potential health effects of bioaccumulated substances.

A 50-g (mussel-tissue homogenate) sample was extracted with acetonitrile in an all-glass Waring blender with stainless steel blades. The homogenized sample was filtered and extracted with petroleum ether. An aliquot of the petroleum ether extract was eluted through a Florisil column. The Florisil columns were eluted with petroleum ether (Fraction 1), 6\% ethyl ether (Fraction 2), 15\% ethyl ether (Fraction 3), and 50\% ethyl ether (Fraction 4). The fractions were concentrated to an appropriate volume in Kuderna-Danish concentrators prior to analysis by gas chromatography. A mixture of synthetic organic standards was eluted through the Florisil column to determine the recovery and separation characteristics of the column. The distribution of synthetic organic compounds in the three fractions is listed in Appendix G; Table G-1.

A Hewlett-Packard 5890A gas chromatograph equipped with a flame ionization detector (FID) and a Finnigan Model ITD 800 ion trap detector (ITD) were used for the identification and quantitation of PAH. A single 30-m DB-5 fused silica capillary column (J \& W), 0.25-mm ID, and 25- $\mu \mathrm{m}$ film thickness were connected to an on-column injector. A Hewlett-Packard 7673A automatic sampler was used for sample introduction. The injector temperature was $285^{\circ} \mathrm{C}$. The column-oven initial temperature was $50^{\circ} \mathrm{C}$ and was held for one minute. The oven was programmed to $190^{\circ} \mathrm{C}$ at a rate of of $25^{\circ} \mathrm{C} / \mathrm{min}$, then to $210^{\circ} \mathrm{C}$ at a rate of $3^{\circ} \mathrm{C} / \mathrm{min}$, and finally to $285^{\circ} \mathrm{C}$ at a rate of $30^{\circ} \mathrm{C} / \mathrm{min}$, and held for 15 minutes. The transfer line to the ITD was set at $285^{\circ} \mathrm{C}$. Samples for PAH analysis were scanned by multiple ion detection (MID) using the following masses:
(1) 101 to 101
(8) 191 to 192
(2) 115 to 129
(9) 202 to 203
(3) 138 to 138
(10) 226 to 229
(4) 141 to 142
(11) 235 to 235
(5) 151 to 156
(12) 252 to 253
(6) 165 to 170
(13) 276 to 279
(7) 176 to 179

Mussel tissues were homogenized and sent out for analysis (Nimbus Labs). Tissues were extracted according to typical methods using dichloromethane (DCM). The extract was subjected to a Florisil cleanup prior to analysis via gas chromatography/mass spectrometry (GC/MS). All individual PAH concentrations measured in mussel-tissue samples are below reporting limits (Appendix G; Table G-3). 


\subsection{Quality Assurance/Quality Control (QA/QC)}

Only those metals that passed quality assurance/quality control (QA/QC) guidelines are considered in subsequent discussions. The QA/QC guidelines are summarized briefly here. The QA/QC guidelines were established prior to analysis to monitor for both precision and accuracy of laboratory and analytical procedures. Guidelines for this study were taken from previously established protocols (Kolak and others, 1998). Certified standard reference materials (SRMs) were obtained from the National Institute for Standards and Technology (NIST) to monitor accuracy during the trace-metal extraction and analysis of sediments. An aliquot of SRM 2704 (Buffalo River Sediment) was digested in the same manner as the sediment samples. Aliquots of SRM 1643d (Trace Metals in Natural Water) were analyzed immediately prior to and following sample analysis to check the accuracy of the ICP-MS calibration. Analyses were considered to fail if measured concentrations were not within $20 \%$ of certified values. Metals for which analyses successfully met all QA/QC criteria include the following: $\mathrm{As}, \mathrm{Cd}, \mathrm{Co}, \mathrm{Mn}, \mathrm{Pb}$, and $\mathrm{Zn}$. Several elements were analyzed that do not have certified values listed for one or both of the SRMs used in this study. These elements ( $\mathrm{Ba}, \mathrm{Cr}, \mathrm{Hg}, \mathrm{Sr}$, and $\mathrm{V}$ ) passed all other aspects of QA/QC protocols, but are considered semi-quantitative due to this lack of verification. More detailed information of QA/QC guidelines and results are given in Appendix $\mathrm{H}$.

\section{DISCUSSION}

4.1 Spatial and temporal patterns seen in the current field over the slope

\subsubsection{Mean current field}

The mean currents over this region of the slope off the Farallon Islands tended to flow toward the northwest, approximately parallel to the isobaths (Table 3). However, the mean flows were not strong at most measurement sites. Over most of the water column, their amplitudes were only large enough to have a stable direction in the fluctuating current environment over the slope in water depths above $200 \mathrm{~m}$ at Moorings D2 and R1 and above $400 \mathrm{~m}$ at Mooring D1. Even in these relatively shallow water depths, the mean speeds were only $2-8 \mathrm{~cm} / \mathrm{s}$. The mean currents near the bed, which could carry suspended material from the deep-water disposal site, flowed down-canyon toward the disposal site at the measurement site nearest the disposal site, Mooring D1. At the two other sites, Moorings D2 and R1, currents flowed along the slope and offshore, away from the Gulf of the Farallones National Marine Sanctuary. Again, mean nearbed current amplitudes were not large; speeds were less than $4 \mathrm{~cm} / \mathrm{s}$.

\subsubsection{Subtidal current field}

The magnitudes of the subtidal current fluctuations, which are fluctuations with periods longer than 33 hours, were strongest in the upper portion of the water column (Table 4). The amplitudes of the subtidal current fluctuations were generally larger than the amplitudes of the mean flow, and they dominated the current field at sites within $1000 \mathrm{~m}$ of the sea surface. Hence, although the mean flows tended to flow toward the northwest, at any particular time, the subtidal portion of the current field could cause flow to be toward the southeast for substantial periods of 
Table 3. Basic statistics for the hour-averaged current records. All units are in $\mathrm{cm} / \mathrm{s}$. For along- and cross-slope currents in water depths shallower than $1300 \mathrm{~m}$ there are 24 and 80 degrees of freedom, respectively. For depths below $1300 \mathrm{~m}$ and for Mooring D2 at $1800 \mathrm{~m}$, there are 80 and 100 degrees of freedom, respectively. The mean error bars are at 95 percent confidence level. Current speeds in water depths shallower than $50 \mathrm{~m}$ at Moorings D1 and R1 are similar to that reported here. Mean currents that have a stable direction, e.g., those that are larger than their error bars, are in bold type. The standard deviation is the average magnitude of current factors at each site, divided by the square root of 2 .

\begin{tabular}{|c|c|c|c|c|c|c|c|c|c|}
\hline \multirow[b]{2}{*}{ D1 } & \multicolumn{3}{|c|}{ Along-slope } & \multicolumn{3}{|c|}{ Cross-slope } & & \multirow{2}{*}{$\begin{array}{c}\begin{array}{c}\text { Direction } \\
(\text { deg. } N)\end{array} \\
\end{array}$} & \multirow{2}{*}{$\begin{array}{c}\text { Maximum } \\
\text { Speed } \\
\end{array}$} \\
\hline & & $\mathrm{AN}$ & STDV & $\mathrm{ME}$ & $\mathrm{AN}$ & STDV & Speed & & \\
\hline $50 \mathrm{~m}$ & 4.9 & \pm 6.0 & 16.9 & 0.6 & \pm 2.2 & 13.0 & 5.0 & 328 & 71.9 \\
\hline $179 \mathrm{~m}$ & 5.5 & \pm 3.4 & 9.7 & 0.4 & \pm 1.2 & 6.4 & 5.3 & 324 & 43.6 \\
\hline $354 \mathrm{~m}$ & 2.9 & \pm 2.8 & 7.8 & 0.4 & \pm 0.5 & 3.8 & 2.9 & 328 & 32.0 \\
\hline $754 \mathrm{~m}$ & 0.0 & \pm 2.3 & 6.8 & 0.6 & \pm 0.4 & 3.1 & 0.6 & 57 & 32.9 \\
\hline $1254 \mathrm{~m}$ & -0.4 & \pm 2.2 & 6.3 & 0.1 & \pm 0.5 & 3.0 & 0.5 & 134 & 28.2 \\
\hline $1954 \mathrm{~m}$ & 0.2 & \pm 0.2 & 3.4 & 0.1 & \pm 0.2 & 2.9 & 0.2 & 356 & 15.7 \\
\hline$* 2354 \mathrm{~m}$ & 0.0 & \pm 0.3 & 4.8 & 0.1 & \pm 0.2 & 2.6 & 0.1 & 346 & 21.4 \\
\hline $\begin{array}{c}* 2394 \mathrm{~m} \\
\text { D2 }\end{array}$ & -0.9 & \pm 0.2 & 6.7 & -0.4 & \pm 0.2 & 3.8 & 1.0 & 305 & 23.9 \\
\hline $90 \mathrm{~m}$ & 7.6 & \pm 5.6 & 15.4 & 1.4 & \pm 1.4 & 9.4 & 7.6 & 330 & 76.4 \\
\hline $215 \mathrm{~m}$ & 6.1 & \pm 3.8 & 10.4 & 1.0 & \pm 0.8 & 5.8 & 6.2 & 329 & 55.9 \\
\hline $390 \mathrm{~m}$ & 1.8 & \pm 3.3 & 9.1 & 0.9 & \pm 0.6 & 4.7 & 2.0 & 345 & 41.0 \\
\hline $790 \mathrm{~m}$ & -0.7 & \pm 2.3 & 7.2 & 0.7 & \pm 0.6 & 4.0 & 1.0 & 94 & 33.5 \\
\hline $1140 \mathrm{~m}$ & 1.3 & \pm 1.6 & 6.3 & 0.2 & \pm 0.4 & 5.6 & 1.4 & 328 & 26.1 \\
\hline $\begin{array}{c}1180 \mathrm{~m} \\
\mathbf{R} 1\end{array}$ & 3.3 & \pm 0.8 & 6.8 & -1.9 & \pm 0.3 & 6.9 & 3.8 & 290 & 30.2 \\
\hline $81 \mathrm{~m}$ & 4.2 & \pm 3.6 & 12.4 & 1.6 & \pm 1.9 & 11.0 & 4.5 & 341 & 55.0 \\
\hline $212 \mathrm{~m}$ & 3.5 & \pm 2.9 & 9.6 & 2.3 & \pm 1.1 & 7.0 & 4.2 & 353 & 36.9 \\
\hline $387 \mathrm{~m}$ & 1.5 & \pm 1.8 & 6.7 & 2.7 & \pm 0.6 & 3.5 & 3.1 & 21 & 31.6 \\
\hline 787 m & 0.2 & \pm 2.6 & 9.3 & -0.6 & \pm 1.0 & 4.3 & 0.6 & 267 & 31.9 \\
\hline $1337 \mathrm{~m}$ & -3.2 & \pm 0.9 & 6.2 & -2.2 & \pm 0.6 & 5.5 & 3.9 & 175 & 23.8 \\
\hline $1377 \mathrm{~m}$ & 1.7 & \pm 0.6 & 7.2 & -0.4 & \pm 0.4 & 5.8 & 1.7 & 306 & 33.8 \\
\hline
\end{tabular}

* Currents are rotated to along- and cross-canyon. 
Table 4. Current variance in the basically sampled current record and the fraction of that variance accounted for by subtidal current fluctuations. Units for variance are $\mathrm{cm} / \mathrm{s}$ squared. The average magnitude of the subtidal fluctuations at each site is the square root of (twice the variance).

\begin{tabular}{|c|c|c|c|c|c|c|}
\hline \multirow[b]{2}{*}{ D1 } & \multicolumn{3}{|c|}{ Along-slope } & \multicolumn{3}{|c|}{ Cross-slope } \\
\hline & \begin{tabular}{|l} 
Variance of \\
basic sample \\
record
\end{tabular} & \begin{tabular}{|c|} 
Variance \\
of subtidal \\
record
\end{tabular} & $\%$ & $\begin{array}{l}\text { Variance of } \\
\text { basic sample } \\
\text { record }\end{array}$ & $\begin{array}{c}\text { Variance } \\
\text { of subtidal } \\
\text { record }\end{array}$ & $\%$ \\
\hline $50 \mathrm{~m}$ & 281.7 & 211.6 & 75 & $\begin{array}{l}169.6 \\
\end{array}$ & $\begin{array}{l}97.0 \\
\end{array}$ & 57 \\
\hline $179 \mathrm{~m}$ & 92.3 & 67.9 & 74 & 40.7 & 27.3 & 67 \\
\hline $354 \mathrm{~m}$ & 61.6 & 46.5 & 76 & 15.1 & 5.8 & 38 \\
\hline $754 \mathrm{~m}$ & 45.8 & 32.3 & 71 & 9.4 & 3.5 & 37 \\
\hline $1254 \mathrm{~m}$ & 39.6 & 29.5 & 75 & 8.8 & 4.7 & 53 \\
\hline $1954 \mathrm{~m}$ & 11.4 & 1.2 & 11 & 8.5 & 1.0 & 12 \\
\hline$* 2354 \mathrm{~m}$ & 23.0 & 1.4 & 6 & 6.7 & 1.2 & 17 \\
\hline $\begin{array}{c}* 2394 \mathrm{~m} \\
\text { D2 }\end{array}$ & 46.9 & 1.3 & 3 & 15.2 & 0.9 & 6 \\
\hline $90 \mathrm{~m}$ & 239.8 & 181.5 & 76 & 91.0 & 40.0 & 44 \\
\hline $215 \mathrm{~m}$ & 109.6 & 86.0 & 79 & 34.7 & 13.6 & 39 \\
\hline $390 \mathrm{~m}$ & 83.9 & 65.7 & 78 & 22.9 & 7.5 & 33 \\
\hline $790 \mathrm{~m}$ & 51.3 & 30.5 & 59 & 16.4 & 6.6 & 40 \\
\hline $1140 \mathrm{~m}$ & 39.1 & 14.8 & 38 & 31.6 & 2.7 & 8 \\
\hline $\begin{array}{c}1180 \mathrm{~m} \\
\mathbf{R} 1\end{array}$ & 47.8 & 12.0 & 25 & 49.8 & 1.9 & 4 \\
\hline $81 \mathrm{~m}$ & 156.3 & 87.1 & 56 & 124.6 & 78.4 & 63 \\
\hline $212 \mathrm{~m}$ & 93.1 & 50.6 & 54 & 50.5 & 26.4 & 52 \\
\hline $387 \mathrm{~m}$ & 42.4 & 22.0 & 52 & 14.9 & 6.2 & 41 \\
\hline $787 \mathrm{~m}$ & 67.0 & 40.1 & 60 & 36.1 & 49.9 & 55 \\
\hline $1337 \mathrm{~m}$ & 34.7 & 16.1 & 46 & 34.2 & 9.2 & 27 \\
\hline $1377 \mathrm{~m}$ & 50.2 & 6.8 & 14 & 35.2 & 5.0 & 14 \\
\hline
\end{tabular}

*: Currents are rotated to along- and cross-canyon. 
time (Appendix C). The proportion of the along-isobath current flow controlled by the subtidal currents tended to drop at measurement sites near the bed (Table 4). In particular, it dropped dramatically to below $10 \%$ of the total variance in the current field at sites on Mooring D1 that lay within the submarine canyon. This is because, as discussed below, the tidal currents dominated flow within this canyon. The subtidal cross-slope current fluctuations were strongest within $100 \mathrm{~m}$ of the water surface, but were generally weaker than the along-slope fluctuations (Table 4).

The energetic subtidal current fluctuations in the shallower portions of the water column tended to be highly correlated in the vertical dimension. That is, they tended to flow in the same direction, and when they reversed directions, it was at the same time. The high resolution nearsurface current fields measured by the ADCPs at Moorings D1 and R1 indicates fluctuations in the subtidal current field were fairly uniform in water depths above 50 to $100 \mathrm{~m}$.

When currents at the several measurement sites are highly correlated within a region, Empirical Orthogonal Functions (EOF) (Joreskog and others, 1976) are a convenient way to represent the dominant spatial and temporal structures in that current field. The first mode of an EOF represents the most energetic spatial pattern associated with the correlated portion of a fluctuating current field. It models both the variation of current amplitudes with location and the common temporal pattern in that set of currents. The second mode represents the next most energetic correlated structure in that current field that is independent of the pattern in the first mode. If there is more than one mode that contains a significant portion of the variance in the measured set of currents, then those several modes usually represent the different independent current patterns that exist in the region.

A modal analysis shows that over $85 \%$ of the energy in both the subtidal along- and cross-slope currents moved in a uniform manner within this near-surface portion of the water column at Moorings D1 and R1 (Tables 5a,b,c,d). The average amplitudes of the correlated along-slope fluctuations were $15-20 \mathrm{~cm} / \mathrm{s}$, much larger than the mean current amplitudes, and amplitudes were approximately uniform with depth. The second mode in the subtidal along-slope near-surface current field suggests that there was a slight tendency for the lower layers to flow in a direction opposite to the surface layer, but the strength of this flow pattern was quite small, almost insignificant compared to the much larger, uniform flow pattern with depth. Average near-surface cross-slope current fluctuations were only slightly weaker than along-slope, with amplitudes of 13-16 cm/s. These subtidal and mean flow patterns suggest that material suspended in the very-near-surface layers would tend to move along the slope toward the northwest, but would be dispersed in both the along- and cross-slope direction as they did so.

The strong, correlated fluctuations seen in the near-surface subtidal along-slope currents represent flow patterns that reach much deeper into the water column. They accounted for $65 \%$ of total current variance at Mooring D1, though their amplitudes were only significant in water depths shallower than $1200 \mathrm{~m}$ (Table 6a). They also accounted for the dominant portion of the subtidal flow field in water depths more than 50 mab at Moorings D2 and R1 (Tables 7a, 8a). The strongest currents in this flow pattern are seen at the surface; amplitudes weaken progressively deeper in the water column. Correlated fluctuations in the subtidal cross-slope current field were confined to much shallower depths; cross-slope surface current fluctuations weakened rapidly with depth and were not correlated with currents below $400 \mathrm{~m}$ (Tables 6b, 7b, $8 b)$. 
Table 5a. Along-slope modes for the near-surface subtidal flow at Mooring D1. Sites where currents are not part of the mode are labeled by a dash.

\begin{tabular}{|c|c|c|c|c|}
\hline \multicolumn{5}{|c|}{$\begin{array}{l}\text { Mode } 1 \text { ( } 85 \% \text { variance) } \\
\text { Mode } 2(14 \% \text { variance })\end{array}$} \\
\hline Depth & $\begin{array}{c}\text { Mode } 1 \\
\text { amplitudes }\end{array}$ & $\begin{array}{r}\text { Mode } 1 \% \\
\text { variances } \\
\end{array}$ & $\begin{array}{c}\text { Mode } 2 \\
\text { amplitudes }\end{array}$ & $\begin{array}{r}\text { Mode } 2 \% \\
\text { variances } \\
\end{array}$ \\
\hline 6 & 31.1 & 59 & -25.8 & 41 \\
\hline 10 & 21.6 & 96 & - & - \\
\hline 14 & 20.7 & 95 & - & - \\
\hline 18 & 20.9 & 94 & - & - \\
\hline 22 & 20.7 & 94 & - & - \\
\hline 26 & 20.5 & 94 & 4.9 & 5 \\
\hline 30 & 20.3 & 94 & 4.9 & 6 \\
\hline 34 & 20.0 & 94 & 4.9 & 6 \\
\hline 38 & 20.0 & 93 & 4.9 & 6 \\
\hline 42 & 19.7 & 92 & 4.9 & 6 \\
\hline 46 & 19.8 & 92 & 4.9 & 6 \\
\hline
\end{tabular}

Table 5b. Cross-slope modes for the near-surface subtidal flow at Mooring D1. Sites where currents are not part of the mode are labeled by a dash.

\begin{tabular}{|}
\hline $\begin{array}{c}\text { Mode 1 (86\% variance) } \\
\text { Mode 2 (11\% variance) }\end{array}$ \\
\hline Depth & $\begin{array}{c}\text { Mode 1 } \\
\text { amplitudes }\end{array}$ & $\begin{array}{c}\text { Mode 1 \% } \\
\text { variances }\end{array}$ & $\begin{array}{c}\text { Mode 2 } \\
\text { amplitudes }\end{array}$ & $\begin{array}{c}\text { Mode 2 \% } \\
\text { variances }\end{array}$ \\
\hline \hline 6 & 23.1 & 69 & -15.0 & 29 \\
\hline 10 & 17.8 & 93 & - & - \\
\hline 14 & 17.0 & 93 & - & - \\
\hline 18 & 16.4 & 94 & - & - \\
\hline 22 & 15.7 & 94 & - & 7 \\
\hline 26 & 15.0 & 94 & - & 9 \\
\hline 30 & 14.3 & 92 & 3.9 & 10 \\
\hline 34 & 13.6 & 88 & 4.3 & 10 \\
\hline 38 & 13.1 & 85 & 4.6 & 9 \\
\hline 42 & 12.7 & 83 & 4.4 & 4.2 & - \\
\hline 46 & 12.8 & 84 & & \\
\hline
\end{tabular}


Table 5c. Along-slope modes for the near-surface subtidal flow at Mooring R1. The data from the two bins nearest the surface exhibited some measurement errors, and was not used in analysis of data for report. Sites where currents are not part of the mode are labeled by a dash.

\begin{tabular}{|c|c|c|c|c|}
\hline \multicolumn{5}{|c|}{$\begin{array}{l}\text { Mode } 1 \text { (93\% variance) } \\
\text { Mode } 2 \text { (4\% variance) }\end{array}$} \\
\hline Depth (m) & $\begin{array}{c}\text { Mode } 1 \\
\text { amplitudes }\end{array}$ & $\begin{array}{l}\text { Mode } 1 \% \\
\text { variances }\end{array}$ & $\begin{array}{c}\text { Mode } 2 \\
\text { amplitudes }\end{array}$ & $\begin{array}{r}\text { Mode } 2 \% \\
\text { variances }\end{array}$ \\
\hline 6 & $\begin{array}{l}11.7 \\
\end{array}$ & 54 & 4.7 & 9 \\
\hline 8 & 14.7 & 84 & 5.2 & 11 \\
\hline 10 & 14.9 & 88 & 4.9 & 9 \\
\hline 12 & 15.1 & 89 & 4.7 & 9 \\
\hline 14 & 15.1 & 91 & 4.4 & 8 \\
\hline 16 & 15.2 & 92 & 4.1 & 7 \\
\hline 18 & 15.3 & 93 & - & - \\
\hline 20 & 15.4 & 94 & - & - \\
\hline 22 & 15.4 & 95 & - & - \\
\hline 24 & 15.3 & 96 & - & - \\
\hline 26 & 15.2 & 96 & - & - \\
\hline 28 & 15.1 & 97 & - & - \\
\hline 30 & 14.9 & 97 & - & - \\
\hline 32 & 14.8 & 97 & - & - \\
\hline 34 & 14.7 & 97 & - & - \\
\hline 36 & 14.7 & 98 & - & - \\
\hline 38 & 14.7 & 98 & - & - \\
\hline 40 & 14.6 & 98 & - & - \\
\hline 42 & 14.5 & 98 & - & - \\
\hline 44 & 14.5 & 98 & - & - \\
\hline 46 & 14.4 & 98 & - & - \\
\hline 48 & 14.3 & 97 & - & - \\
\hline 50 & 14.2 & 97 & - & - \\
\hline 52 & 14.1 & 97 & - & - \\
\hline 54 & 14.0 & 97 & - & - \\
\hline 56 & 14.0 & 96 & - & - \\
\hline 58 & 13.9 & 96 & - & - \\
\hline 60 & 13.8 & 95 & - & - \\
\hline 62 & 13.8 & 95 & - & - \\
\hline 64 & 13.6 & 94 & - & - \\
\hline 66 & 13.5 & 93 & -3.2 & 5 \\
\hline 68 & 13.3 & 93 & -3.4 & 6 \\
\hline 70 & 13.1 & 92 & -3.5 & 7 \\
\hline 72 & 12.9 & 91 & -3.5 & 7 \\
\hline 74 & 12.7 & 90 & -3.6 & 7 \\
\hline 76 & 12.5 & 90 & -3.6 & 7 \\
\hline 78 & 12.3 & 89 & -3.6 & 8 \\
\hline 80 & 12.1 & 89 & -3.6 & 8 \\
\hline 82 & 11.8 & 88 & -3.5 & 8 \\
\hline
\end{tabular}


Table 5d. Cross-slope modes for the near-surface subtidal flow at Mooring R1. The data from the two bins nearest the surface exhibited some measurement errors, and was not used in analysis of data for report. Sites where currents are not part of the mode are labeled by a dash.

\begin{tabular}{|c|c|c|c|c|}
\hline \multicolumn{5}{|c|}{$\begin{array}{l}\text { Mode } 1 \text { ( } 89 \% \text { variance) } \\
\text { Mode } 2 \text { ( } 7 \% \text { variance) }\end{array}$} \\
\hline Depth (m) & $\begin{array}{c}\text { Mode } 1 \\
\text { amplitudes }\end{array}$ & $\begin{array}{c}\text { Mode } 1 \% \\
\text { variances }\end{array}$ & $\begin{array}{c}\text { Mode } 2 \\
\text { amplitudes }\end{array}$ & $\begin{array}{r}\text { Mode } 2 \% \\
\text { variances } \\
\end{array}$ \\
\hline 6 & 13.2 & 59 & -8.1 & 22 \\
\hline 8 & 15.6 & 80 & -6.7 & 15 \\
\hline 10 & 15.6 & 84 & -6.2 & 13 \\
\hline 12 & 15.5 & 86 & -5.8 & 12 \\
\hline 14 & 15.3 & 87 & -5.5 & 11 \\
\hline 16 & 15.2 & 88 & -5.2 & 10 \\
\hline 18 & 15.0 & 89 & -4.8 & 9 \\
\hline 20 & 14.8 & 90 & -4.3 & 8 \\
\hline 22 & 14.5 & 92 & -3.7 & 6 \\
\hline 24 & 14.3 & 93 & -3.0 & 4 \\
\hline 26 & 14.0 & 94 & -2.3 & 3 \\
\hline 28 & 13.9 & 94 & - & - \\
\hline 30 & 13.7 & 95 & - & - \\
\hline 32 & 13.6 & 95 & - & - \\
\hline 34 & 13.5 & 95 & - & - \\
\hline 36 & 13.4 & 95 & - & - \\
\hline 38 & 13.4 & 95 & - & - \\
\hline 40 & 13.3 & 95 & - & - \\
\hline 42 & 13.3 & 95 & - & - \\
\hline 44 & 13.2 & 95 & - & - \\
\hline 46 & 13.1 & 85 & - & - \\
\hline 48 & 13.0 & 94 & - & - \\
\hline 50 & 12.9 & 94 & - & - \\
\hline 52 & 12.8 & 93 & - & - \\
\hline 54 & 12.7 & 94 & - & - \\
\hline 56 & 12.5 & 93 & 3.1 & 6 \\
\hline 58 & 12.4 & 92 & 3.3 & 7 \\
\hline 60 & 12.3 & 91 & 3.5 & 7 \\
\hline 62 & 12.2 & 90 & 3.6 & 8 \\
\hline 64 & 12.1 & 90 & 3.7 & 8 \\
\hline 66 & 12.1 & 89 & 3.8 & 9 \\
\hline 68 & 12.0 & 89 & 3.9 & 9 \\
\hline 70 & 11.9 & 88 & 3.9 & 9 \\
\hline 72 & 11.8 & 87 & 3.9 & 10 \\
\hline 74 & 11.8 & 86 & 4.0 & 10 \\
\hline 76 & 11.6 & 86 & 4.0 & 10 \\
\hline 78 & 11.4 & 85 & 4.0 & 10. \\
\hline 80 & 11.1 & 84 & 3.9 & 10 \\
\hline 82 & 10.8 & 82 & 3.9 & 11 \\
\hline
\end{tabular}


Table 6a. Along-slope modes for subtidal flow at all depth levels at Mooring D1. Current at $54 \mathrm{~m}$ is the depth average flow from the ADCP. Sites where currents are not part of the mode are labeled by a dash.

\begin{tabular}{|}
\hline $\begin{array}{l}\text { Mode 1 (65\% variance) } \\
\text { Mode 2 (27\% variance) }\end{array}$ \\
\hline $\begin{array}{c}\text { Depth (m) } \\
\text { Mode 1 } \\
\text { amplitudes }\end{array}$ & $\begin{array}{c}\text { Mode 1 \% } \\
\text { variances }\end{array}$ & $\begin{array}{c}\text { Mode 2 } \\
\text { amplitudes }\end{array}$ & $\begin{array}{c}\text { Mode 2 \% } \\
\text { variances }\end{array}$ \\
\hline \hline 26 & 19.9 & 90 & -6.5 & 10 \\
\hline 179 & 9.0 & 59 & 6.0 & 27 \\
\hline 354 & 5.6 & 34 & 7.4 & 59 \\
\hline 754 & 3.0 & 14 & 6.7 & 69 \\
\hline 1254 & 2.2 & 8 & 6.2 & 64 \\
\hline 1954 & - & - & - & - \\
\hline 2354 & - & - & - & - \\
\hline 2394 & - & - & - & - \\
\hline
\end{tabular}

Modes created using only the bottom three instruments at Mooring D1. Bottom two instruments were rotated into canyon coordinates, and top instrument was rotated into alongslope coordinates. Sites where currents are not part of the mode are labeled by a dash.

\begin{tabular}{|c|c|c|c|c|}
\hline \multicolumn{5}{|c|}{$\begin{array}{l}\text { Mode } 1 \text { (52\% variance) } \\
\text { Mode } 2 \text { (31\% variance) }\end{array}$} \\
\hline Depth (m) & $\begin{array}{c}\text { Mode } 1 \\
\text { amplitudes }\end{array}$ & $\begin{array}{r}\text { Mode } 1 \% \\
\text { variances }\end{array}$ & $\begin{array}{c}\text { Mode } 2 \\
\text { amplitudes }\end{array}$ & $\begin{array}{r}\text { Mode } 2 \% \\
\text { variances }\end{array}$ \\
\hline 1954 & 0.4 & 7 & 1.5 & 93 \\
\hline 2354 & 1.4 & 77 & - & - \\
\hline 2394 & 1.3 & 68 & - & - \\
\hline
\end{tabular}

Table 6b. Cross-slope modes for subtidal flow at all depth levels at Mooring D1. Bottom two instruments were rotated into canyon coordinates. Sites where currents are not part of the mode are labeled by a dash.

\begin{tabular}{|c|c|c|c|c|}
\hline \multicolumn{5}{|c|}{$\begin{array}{l}\text { Mode } 1 \text { (77\% variance) } \\
\text { Mode } 2(15 \% \text { variance) }\end{array}$} \\
\hline Depth (m) & $\begin{array}{c}\text { Mode } 1 \\
\text { amplitudes } \\
\end{array}$ & $\begin{array}{r}\text { Mode } 1 \% \\
\text { variances } \\
\end{array}$ & $\begin{array}{c}\text { Mode } 2 \\
\text { amplitudes } \\
\end{array}$ & $\begin{array}{r}\text { Mode } 2 \% \\
\text { variances } \\
\end{array}$ \\
\hline 26 & 13.9 & 98 & - & - \\
\hline 179 & 4.4 & 36 & 5.7 & 62 \\
\hline 354 & 2.1 & 31 & 2.4 & 42 \\
\hline 754 & - & - & - & - \\
\hline 1254 & - & - & - & - \\
\hline 1954 & - & - & - & - \\
\hline 2354 & - & - & - & - \\
\hline 2394 & - & - & - & - \\
\hline
\end{tabular}


Table 7a. Along-slope modes for subtidal flow at all depth levels at Mooring D2. Sites where currents are not part of the mode are labeled by a dash.

\begin{tabular}{|c|c|c|c|c|}
\hline \multicolumn{5}{|c|}{$\begin{array}{l}\text { Mode } 1 \text { (67\% variance) } \\
\text { Mode } 2(22 \% \text { variance })\end{array}$} \\
\hline Depth (m) & $\begin{array}{c}\text { Mode } 1 \\
\text { amplitudes } \\
\end{array}$ & $\begin{array}{r}\text { Mode } 1 \% \\
\text { variances } \\
\end{array}$ & $\begin{array}{c}\text { Mode } 2 \\
\text { amplitudes }\end{array}$ & $\begin{array}{r}\text { Mode } 2 \% \\
\text { variances } \\
\end{array}$ \\
\hline 90 & 17.9 & 84 & -7.9 & 16 \\
\hline 215 & 12.0 & 80 & - & - \\
\hline 390 & 8.1 & 51 & 7.5 & 44 \\
\hline 790 & 3.5 & 21 & 5.4 & 49 \\
\hline 1140 & - & - & - & - \\
\hline 1180 & - & - & - & - \\
\hline
\end{tabular}

Table 7b. Cross-slope modes for subtidal flow at all depth levels at Mooring D2. Sites where currents are not part of the mode are labeled by a dash.

\begin{tabular}{|c|c|c|c|c|}
\hline \multicolumn{5}{|c|}{$\begin{array}{l}\text { Mode } 1 \text { ( } 71 \% \text { variance }) \\
\text { Mode } 2(12 \% \text { variance })\end{array}$} \\
\hline Depth (m) & $\begin{array}{c}\text { Mode } 1 \\
\text { amplitudes }\end{array}$ & $\begin{array}{l}\text { Mode } 1 \% \\
\text { variances }\end{array}$ & $\begin{array}{c}\text { Mode } 2 \\
\text { amplitudes }\end{array}$ & $\begin{array}{l}\text { Mode } 2 \% \\
\text { variances }\end{array}$ \\
\hline 90 & 9.0 & 97 & - & - \\
\hline 215 & 4.3 & 70 & 1.9 & 14 \\
\hline 390 & 1.7 & 20 & 2.8 & 56 \\
\hline 790 & - & - & 1.6 & 20 \\
\hline 1140 & - & - & - & - \\
\hline 1180 & - & - & - & - \\
\hline
\end{tabular}


Table 8a. Along-slope modes for subtidal flow at all depth levels at Mooring R1. Sites where currents are not significantly in the mode are labeled by a dash.

\begin{tabular}{|c|c|c|c|c|}
\hline \multicolumn{5}{|c|}{$\begin{array}{l}\text { Mode } 1 \text { (68\% variance) } \\
\text { Mode } 2(25 \% \text { variance })\end{array}$} \\
\hline Depth (m) & $\begin{array}{c}\text { Mode } 1 \\
\text { amplitudes } \\
\end{array}$ & $\begin{array}{r}\text { Mode } 1 \% \\
\text { variances } \\
\end{array}$ & $\begin{array}{c}\text { Mode } 2 \\
\text { amplitudes } \\
\end{array}$ & $\begin{array}{r}\text { Mode } 2 \% \\
\text { variances } \\
\end{array}$ \\
\hline 40 & 11.1 & 78.1 & -5.6 & 20.1 \\
\hline 212 & 9.5 & 92.1 & 0.2 & 0.1 \\
\hline 387 & 5.3 & 64.6 & 3.1 & 22.3 \\
\hline 787 & 5.6 & 35.3 & 7.4 & 61.5 \\
\hline 1377 & - & - & 1.9 & 26.7 \\
\hline
\end{tabular}

Table 8b. Cross-slope modes for subtidal flow at all depth levels at Mooring R1. Sites where currents are not significantly in the mode are labeled by a dash.

\begin{tabular}{|c|c|c|c|c|}
\hline \multicolumn{5}{|c|}{$\begin{array}{l}\text { Mode } 1 \text { ( } 68 \% \text { variance }) \\
\text { Mode } 2 \text { (25\% variance) }\end{array}$} \\
\hline Depth (m) & $\begin{array}{c}\text { Mode } 1 \\
\text { amplitudes }\end{array}$ & $\begin{array}{r}\text { Mode } 1 \% \\
\text { variances }\end{array}$ & $\begin{array}{c}\text { Mode } 2 \\
\text { amplitudes }\end{array}$ & $\begin{array}{r}\text { Mode } 2 \% \\
\text { variances }\end{array}$ \\
\hline 40 & 14.1 & 98.4 & - & - \\
\hline 212 & 5.8 & 71.2 & - & - \\
\hline 387 & 1.8 & 32.4 & 1.7 & 30.6 \\
\hline 787 & - & - & 4.2 & 75.6 \\
\hline 1377 & - & - & 0.9 & 12.4 \\
\hline
\end{tabular}


Fluctuations in the subtidal along-slope current field were not only correlated with depth at each site, but were correlated over the entire study area. In the surface layers, over $75 \%$ of the subtidal along-slope current fluctuations flowed in the same direction (Table 9a). Near-surface subtidal along-slope current amplitudes were $11-20 \mathrm{~cm} / \mathrm{s}$, much stronger than the mean flow. Within the water column the along-slope subtidal currents were also correlated over the entire slope. Over $50 \%$ of the variability in this flow field in depths more than $50 \mathrm{~m}$ above the bed and above $1200 \mathrm{~m}$ moved in the same direction across the slope (Table 10a).

The second mode for the subtidal along-slope flow field suggests that, although flows in the surface layer reached deep into the water column, they did not totally dominate these deeper flows. About 20-60\% of the along-slope current fluctuation at depths below $300 \mathrm{~m}$, but above 800-1200 m, flowed in the opposite direction to the surface flows (Table 10a). At these lower depths, the amplitude of the currents in mode 2 was nearly equal to or perhaps stronger than the currents in mode 1.

Near the sea floor, fluctuations in the subtidal current fields were independent of each other and of the overlying flow fields (Tables 6a, 7a, 8a). The subtidal currents flowing along the submarine canyon just onshore of the disposal site at Mooring D1 were similar to each other, but were not related to fluctuation in the current field just above the canyon. The subtidal alongslope flows within $50 \mathrm{~m}$ of the bed at Moorings D2 and R1 were also independent of the overlying current field and each other.

Correlated fluctuations in the subtidal cross-slope flow field over the entire slope are strongly surface-intensified (Table 9b), similar to the patterns seen in the along-slope flow field. However, the spatial structures in the subtidal cross-slope flow field tend to be much smaller than those found in the along-slope flow. In the surface flow field, most of the cross-slope variability is unique to a measurement site. At depths below $100 \mathrm{~m}$, correlated cross-slope current fluctuations are weak, with speeds less than $4 \mathrm{~cm} / \mathrm{s}$ (Table 10b). Across the region, around $50 \%$ of the cross-slope fluctuations are correlated among the three measurement sites; however, most of that variance is found at Mooring D1 (Table 10b). Only 24-34\% of the crossslope variability at the other two sites is related to flow at Mooring D1. It is interesting to note that the dominant pattern for cross-slope flow in the second mode is for cross-slope flow above $800 \mathrm{~m}$ at Mooring D1 to oppose the cross-slope flow at Mooring D2.

\subsubsection{Tidal current field}

Tidal currents tended to be the dominant constituents of the cross-slope flow field in water depths below $200 \mathrm{~m}$ (Table 4). They also tended to be the dominant along-slope current component in water depths below $1200 \mathrm{~m}$. Hence, they were the dominant current component at sites near the bed and within the submarine canyon near the disposal site.

Except at sites very near the sea surface, where diurnal winds amplified the fluctuations in the diurnal $\mathrm{K}_{1}$ tidal band, the semidiurnal $\mathrm{M}_{2}$ tidal currents were the largest tidal constituent (Table 11; Appendix B). The amplitude of $\mathrm{M}_{2}$ tidal currents generally lay between 3 and $7 \mathrm{~cm} / \mathrm{s}$. Semidiurnal current fluctuations were oriented slightly more along than across the slope isobaths in the main portion of the water column. At Mooring D1, the amplitude of both tidal constituents increased slightly, and the orientation of the flow field changed to along-canyon once the measurement sites were below the canyon rim (Table 11), as one might expect for flow fields in 
Table 9a. Surface along-slope modes for subtidal flow at Moorings D1, D2, and R1. Sites where currents are not part of the mode are labeled by a dash.

\begin{tabular}{|c|c|c|c|c|}
\hline \multicolumn{5}{|c|}{$\begin{array}{l}\text { Mode } 1 \text { (76\% variance) } \\
\text { Mode } 2(14 \% \text { variance })\end{array}$} \\
\hline Mooring & $\begin{array}{c}\text { Mode } 1 \\
\text { amplitudes }\end{array}$ & $\begin{array}{c}\text { Mode } 1 \% \\
\text { variances } \\
\end{array}$ & $\begin{array}{c}\text { Mode } 2 \\
\text { amplitudes } \\
\end{array}$ & $\begin{array}{r}\text { Mode } 2 \% \\
\text { variances } \\
\end{array}$ \\
\hline D1-26 & 19.6 & 86.0 & - & - \\
\hline D2-90 & 15.7 & 73.7 & 9.1 & 24.8 \\
\hline $\mathrm{R} 1-40$ & 10.7 & 56.6 & - & - \\
\hline
\end{tabular}

Table 9b. Surface cross-slope modes for subtidal flow at Moorings D1, D2, and R1. Sites where currents are not part of the mode are labeled by a dash.

\begin{tabular}{|c|c|c|c|c||}
\hline \multicolumn{4}{|l||}{$\begin{array}{l}\text { Mode 1 (51\% variance) } \\
\text { Mode 2 (34\% variance) }\end{array}$} & $\begin{array}{c}\text { Mode 2 \% } \\
\text { variances }\end{array}$ \\
\hline Mooring & $\begin{array}{c}\text { Mode 1 } \\
\text { amplitudes }\end{array}$ & $\begin{array}{c}\text { Mode 1 \% } \\
\text { variances }\end{array}$ & $\begin{array}{c}\text { Mode 2 } \\
\text { amplitudes }\end{array}$ & 19.1 \\
\hline \hline D1-26 & 13.4 & 78.0 & 6.6 & - \\
\hline D2-90 & 4.7 & 23.9 & - & 66.1 \\
\hline R1-40 & 8.3 & 33.8 & -11.6 & \\
\hline
\end{tabular}


Table 10a. The joint along-slope modes for subtidal flow at all sites at Moorings D1, D2, and R1. Sites where currents are not part of the mode are labeled by a dash.

\begin{tabular}{|c|c|c|c|c|}
\hline \multicolumn{5}{|c|}{$\begin{array}{l}\text { Mode } 1(51 \% \text { variance }) \\
\text { Mode } 2(22 \% \text { variance })\end{array}$} \\
\hline Mooring & $\begin{array}{c}\text { Mode } 1 \\
\text { amplitudes }\end{array}$ & $\begin{array}{r}\text { Mode } 1 \% \\
\text { variances }\end{array}$ & $\begin{array}{c}\text { Mode } 2 \\
\text { amplitudes }\end{array}$ & $\begin{array}{r}\text { Mode } 2 \% \\
\text { variances } \\
\end{array}$ \\
\hline D1-26 & 16.8 & 63.6 & -10.1 & 22.8 \\
\hline D1-179 & 9.5 & 65.0 & 3.4 & 8.2 \\
\hline D1-354 & 6.6 & 48.9 & 5.8 & 38.2 \\
\hline D1-754 & 3.8 & 22.4 & 6.1 & 57.2 \\
\hline D1-1254 & 3.0 & 13.9 & 5.9 & 52.9 \\
\hline D1-1954 & - & - & - & - \\
\hline D1-2354 & - & - & - & - \\
\hline D1-2394 & - & - & - & - \\
\hline D2-90 & 15.0 & 66.8 & -5.0 & 7.5 \\
\hline D2-215 & 8.5 & 56.8 & 5.0 & 19.9 \\
\hline D2-390 & 6.1 & 35.4 & 7.4 & 51.3 \\
\hline D2-790 & 2.4 & 11.2 & 4.8 & 43.6 \\
\hline D2-1140 & - & - & - & - \\
\hline D2-1190 & - & - & - & - \\
\hline $\mathrm{R} 1-40$ & 10.5 & 54.2 & -3.0 & 4.4 \\
\hline R1-212 & 7.2 & 53.8 & 2.4 & 5.8 \\
\hline R1-387 & 4.3 & 41.8 & 3.6 & 29.0 \\
\hline $\mathrm{R} 1-787$ & 4.2 & 19.6 & 7.5 & 61.3 \\
\hline R1-1377 & - & - & 2.0 & 29.8 \\
\hline
\end{tabular}


Table 10b. The joint cross-slope modes for subtidal flow at all sites at Moorings D1, D2, and R1. Sites where currents are not part of the mode are labeled by a dash.

\begin{tabular}{|c|c|c|c|c|}
\hline \multicolumn{5}{|c|}{$\begin{array}{l}\text { Mode } 1 \text { (39\% variance) } \\
\text { Mode } 2 \text { (28\% variance) }\end{array}$} \\
\hline Mooring & $\begin{array}{c}\text { Mode } 1 \\
\text { amplitudes }\end{array}$ & $\begin{array}{c}\text { Mode } 1 \% \\
\text { variances }\end{array}$ & $\begin{array}{c}\text { Mode } 2 \\
\text { amplitudes }\end{array}$ & $\begin{array}{r}\text { Mode } 2 \% \\
\text { variances } \\
\end{array}$ \\
\hline D1-26 & 12.9 & 72.1 & -6.8 & 19.9 \\
\hline D1-179 & 3.5 & 20.0 & -3.8 & 23.3 \\
\hline D1-354 & 1.7 & 20.4 & -1.5 & 15.9 \\
\hline D1-754 & - & - & -0.7 & 7.0 \\
\hline D1-1254 & - & - & - & - \\
\hline D1-1954 & - & - & - & - \\
\hline D1-2354 & - & - & - & - \\
\hline D1-2394 & - & - & - & - \\
\hline D2-90 & 5.1 & 28.2 & - & - \\
\hline D2-215 & 2.5 & 21.4 & - & - \\
\hline D2-390 & 1.0 & 8.3 & - & - \\
\hline D2-790 & 1.0 & 7.1 & - & - \\
\hline D2-1140 & - & - & - & - \\
\hline D2-1190 & - & - & - & - \\
\hline $\mathrm{R} 1-40$ & 8.6 & 36.4 & 11.1 & 61.3 \\
\hline R1-212 & 3.3 & 22.8 & 4.8 & 49.5 \\
\hline R1-387 & 1.1 & 13.4 & 1.4 & 20.2 \\
\hline R1-787 & - & - & - & - \\
\hline R1-1377 & - & - & - & - \\
\hline
\end{tabular}


Table 11. Tidal current constituents analyzed from mooring measurements. A negative minor axis indicates a clockwise rotation. The inclination angle is counterclockwise from East.

\begin{tabular}{|c|c|c|c|c|c|c|c|c|c|c|c|c|}
\hline \multirow[t]{2}{*}{$\begin{array}{l}\text { Mooring and } \\
\text { depth (m) }\end{array}$} & \multicolumn{3}{|c|}{$\mathrm{O} 1$} & \multicolumn{3}{|c|}{$\mathrm{K} 1$} & \multicolumn{3}{|c|}{ M2 } & \multicolumn{3}{|c|}{$\mathrm{S} 2$} \\
\hline & $\begin{array}{c}\text { Major } \\
\mathrm{cm} / \mathrm{s}\end{array}$ & $\begin{array}{l}\text { Minor } \\
\mathrm{cm} / \mathrm{s}\end{array}$ & $\begin{array}{l}\text { Inclin. } \\
\text { degree }\end{array}$ & $\begin{array}{l}\text { Major } \\
\mathrm{cm} / \mathrm{s}\end{array}$ & $\begin{array}{l}\text { Minor } \\
\mathrm{cm} / \mathrm{s}\end{array}$ & $\begin{array}{l}\text { Inclin. } \\
\text { degree }\end{array}$ & $\begin{array}{l}\text { Major } \\
\mathrm{cm} / \mathrm{s}\end{array}$ & $\begin{array}{c}\text { Minor } \\
\mathrm{cm} / \mathrm{s}\end{array}$ & $\begin{array}{l}\text { Inclin. } \\
\text { degree }\end{array}$ & $\begin{array}{l}\text { Major } \\
\mathrm{cm} / \mathrm{s}\end{array}$ & $\begin{array}{c}\text { Minor } \\
\mathrm{cm} / \mathrm{s}\end{array}$ & $\begin{array}{l}\text { Inclin. } \\
\text { degree }\end{array}$ \\
\hline 50 & 1.6 & -0.3 & 81 & 3.0 & $\begin{array}{l}-1.0 \\
\end{array}$ & 97 & 4.2 & -1.5 & 114 & 2.1 & $2-0.4$ & 66 \\
\hline 179 & 1.0 & 0.2 & 114 & 1.4 & 0.4 & 117 & 3.1 & -0.1 & 100 & 1.3 & -0.1 & 95 \\
\hline 354 & 0.8 & 0.2 & 118 & 1.3 & 0.3 & 119 & 2.1 & 0.8 & 107 & 1.0 & 0.2 & 113 \\
\hline 754 & 0.6 & 0.0 & 112 & 1.0 & -0.0 & 115 & 3.3 & -0.7 & 124 & 1.3 & -0.4 & 147 \\
\hline 1254 & 0.7 & -0.2 & 130 & 1.0 & -0.3 & 130 & 2.8 & -0.1 & 140 & 1.2 & -0.1 & 145 \\
\hline 1954 & 1.3 & -0.3 & 155 & 1.9 & -0.4 & 155 & 1.8 & 1.1 & 26 & 0.7 & 0.5 & 114 \\
\hline 2354 & 1.1 & 0.1 & 173 & 1.1 & -0.0 & 170 & 3.5 & 0.1 & 5 & 1.8 & -0.1 & 2 \\
\hline 2394 & 1.5 & 0.2 & 174 & 1.4 & 0.3 & 169 & 4.7 & 0.4 & 169 & 2.6 & -0.4 & 176 \\
\hline \multicolumn{13}{|l|}{ D2 } \\
\hline 90 & 1.6 & 0.2 & 89 & 2.8 & -0.7 & 101 & 3.5 & 1.2 & 134 & 1.8 & 0.3 & 72 \\
\hline 215 & 1.5 & 0.3 & 114 & 2.3 & 0.3 & 120 & 2.2 & 1.2 & 66 & 1.0 & 0.4 & 95 \\
\hline 390 & 1.3 & 0.2 & 114 & 2.0 & 0.2 & 119 & 2.4 & 0.7 & 103 & 1.1 & -0.1 & 141 \\
\hline 790 & 1.9 & 0.3 & 111 & 1.0 & -0.4 & 119 & 4.6 & -1.1 & 140 & 1.6 & -0.4 & 144 \\
\hline 1140 & 1.3 & 0.1 & 133 & 2.3 & 0.1 & 132 & 4.7 & 0.7 & 66 & 2.1 & -0.2 & 98 \\
\hline 1180 & 1.8 & -0.1 & 123 & 3.4 & 0.0 & 133 & 5.6 & 1.7 & 61 & 2.4 & 0.4 & 96 \\
\hline \multicolumn{13}{|l|}{ R1 } \\
\hline 81 & 1.1 & 0.2 & 106 & 1.8 & 0.0 & 110 & 6.6 & -2.7 & 128 & 2.0 & -0.1 & 127 \\
\hline 212 & 0.9 & 0.3 & 102 & 1.6 & 0.3 & 93 & 5.9 & -2.3 & 127 & 1.1 & 0.4 & 103 \\
\hline 387 & 0.8 & 0.1 & 94 & 1.3 & 0.2 & 96 & 3.1 & -0.5 & 122 & 1.2 & -0.1 & 93 \\
\hline 787 & 1.3 & -0.1 & 79 & 2.0 & -0.1 & 81 & 5.1 & -1.2 & 102 & 2.0 & -0.5 & 113 \\
\hline 1337 & 1.0 & -0.1 & 67 & 1.7 & -0.4 & 57 & 4.2 & 0.7 & 24 & 2.2 & -0.3 & 155 \\
\hline 13 & 1.3 & -0.5 & 34 & 1.8 & -0.9 & 42 & 3.4 & 1.1 & 104 & 2.0 & -0.3 & 115 \\
\hline
\end{tabular}


a topographically constricted setting. There is a suggestion that the semidiurnal tidal currents increased slightly within the canyon at Mooring D1 and near the bed at Mooring D2.

The diurnal tidal currents, $\mathrm{O}_{1}$ and $\mathrm{K}_{1}$, were weaker than the semidiurnal constituents. Their amplitudes tended to be less than $3 \mathrm{~cm} / \mathrm{s}$. Over most of the water column, diurnal current fluctuations were oriented along the slope, similar to the orientation of the semidiurnal tidal currents. The diurnal tidal currents did not show any particular tendency to increase at sites near the bed.

\subsection{Resuspension potential for sediments deposited on the slope}

Even though, over the 12-month observation, the highest current speeds were found at the shallowest depths (Table 3), higher current speeds were also found in the bottom boundary layer that lies within $50 \mathrm{~m}$ of the seabed. At Mooring D1, the intensification of the currents near the bed was probably due to the presence of a small submarine canyon. However, given that the near-bed intensification was found at all measurement sites, this intensification of bottom currents may be a general feature over this region of the continental slope.

The bed-shear stress, $\tau$, which is used to predict sediment resuspension as a function of grain size, can be estimated using the observed current measured near the sea floor and the "law of the wall", providing one assumes that the logarithmic layer extends at least up to 10 mab:

$$
\begin{array}{r}
\tau=\rho u_{*}^{2} \\
\frac{u}{u_{*}}=\frac{1}{\kappa} \ln \left(\frac{z}{z_{0}}\right)
\end{array}
$$

where $u_{*}$ is the shear velocity, $\rho$ is water density, $u$ is the measured velocity at 10 mab, $\kappa=0.4$ is the von Karman constant, $\mathrm{z}=10 \mathrm{~m}, \mathrm{z}_{0}=\mathrm{k}_{\mathrm{b}} / 30$ is bed roughness length. $\mathrm{k}_{\mathrm{b}}$ in the last equation is known as roughness. In the above equations $\mathrm{z}_{0}$ is the only unknown. If the seabed were flat, $\mathrm{k}_{\mathrm{b}}$ could have been estimated by an empirical formula that relates bed roughness to sediment grain size. However, bottom photos (SAIC, 1991) show that the seabed at the dumpsite and vicinity area is not flat. Although it is impossible to make accurate calculations of the roughness from just a few photos, we nevertheless can use them to estimate the maximum and minimum roughness amplitude. Four values of roughness within this range are used to estimate the bedshear stress at Mooring D1 (Figure 4).

Fine sand, which requires a bed-shear stress of $1.02 \mathrm{dyne} / \mathrm{cm}^{2}$ to be resuspended from the sea floor (Gardner, 1989), was never resuspended at Mooring D1, even when we use the highest possible roughness amplitude $\left(\mathrm{k}_{\mathrm{b}}=1 \mathrm{~cm}\right)$. Resuspension of deep-sea mud depends on various factors, such as erodability and the pressure of aggregates; thus the critical shear stress widely varies (0.2-1.5 dyne/ $\mathrm{cm}^{2}$ ) (Thomsen and Gust, 2000). Without the knowledge of the texture of the deep-sea floor at the site, we chose to use $0.4 \mathrm{dyne} / \mathrm{cm}^{2}$ (Gardner, 1989) as a representation of the critical shear stress for mud (silt and clay). At Mooring D1 resuspension of mud was rare, but certainly possible, even under moderate bed-roughness conditions. Concentration profiles calculated using a simplified formula (Dyer and Soulsby, 1988) show that $60-80 \%$ of fine silts, once resuspended, reached 10 mab (Figure 5). Similar estimation for Moorings D2 and R1, assuming the same type of bed-roughness values, shows that bottom resuspension events at the 

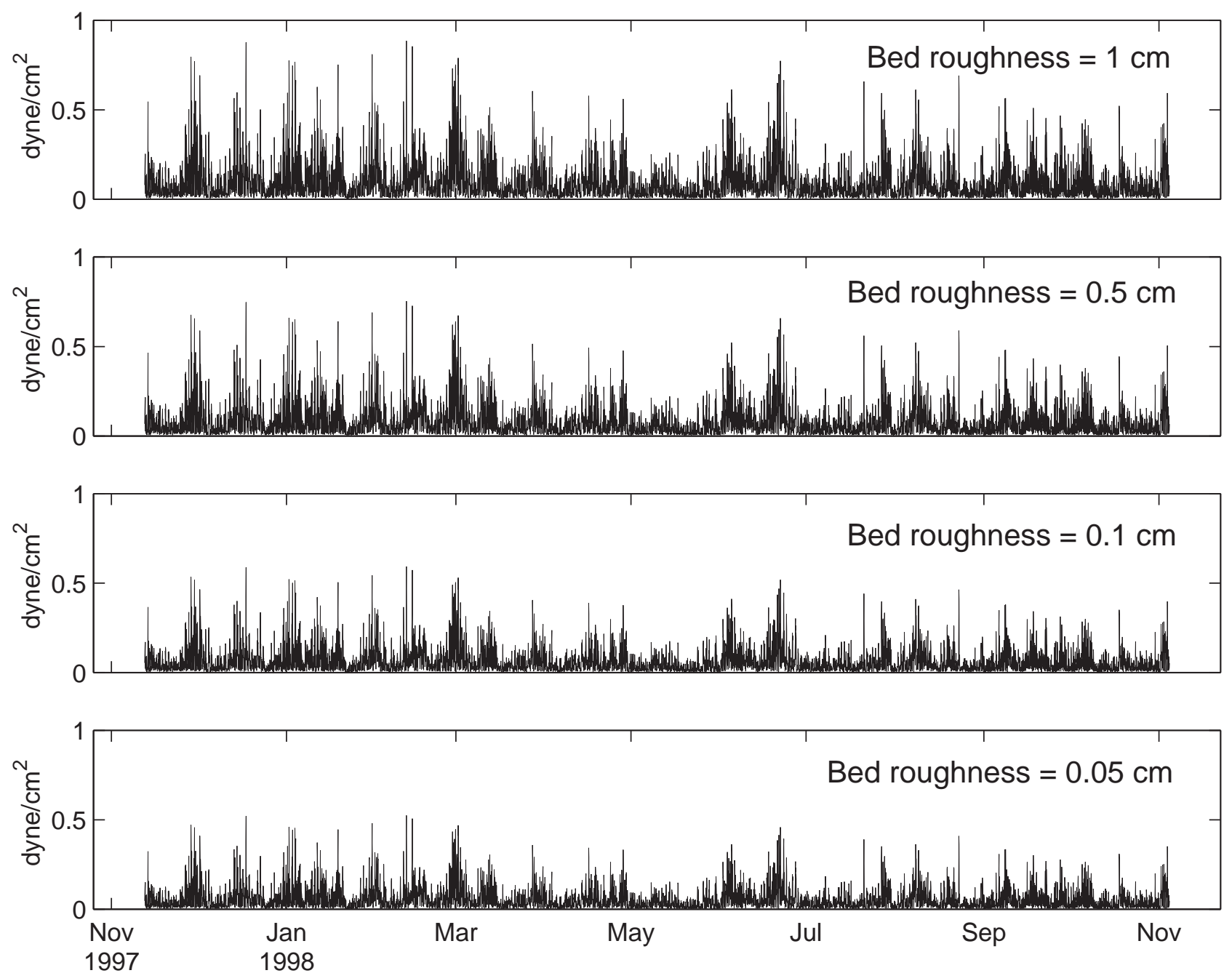

Figure 4. Modeled bed-shear stress at Mooring D1 with four different bed-roughness values. Resuspension of sand, requiring shear stress of 1.02 dyne $/ \mathrm{cm}^{2}$, never occurred during the deployment. Resuspension of mud, requiring shear stress of $0.4 \mathrm{dyne} / \mathrm{cm}^{2}$, was certainly possible. 


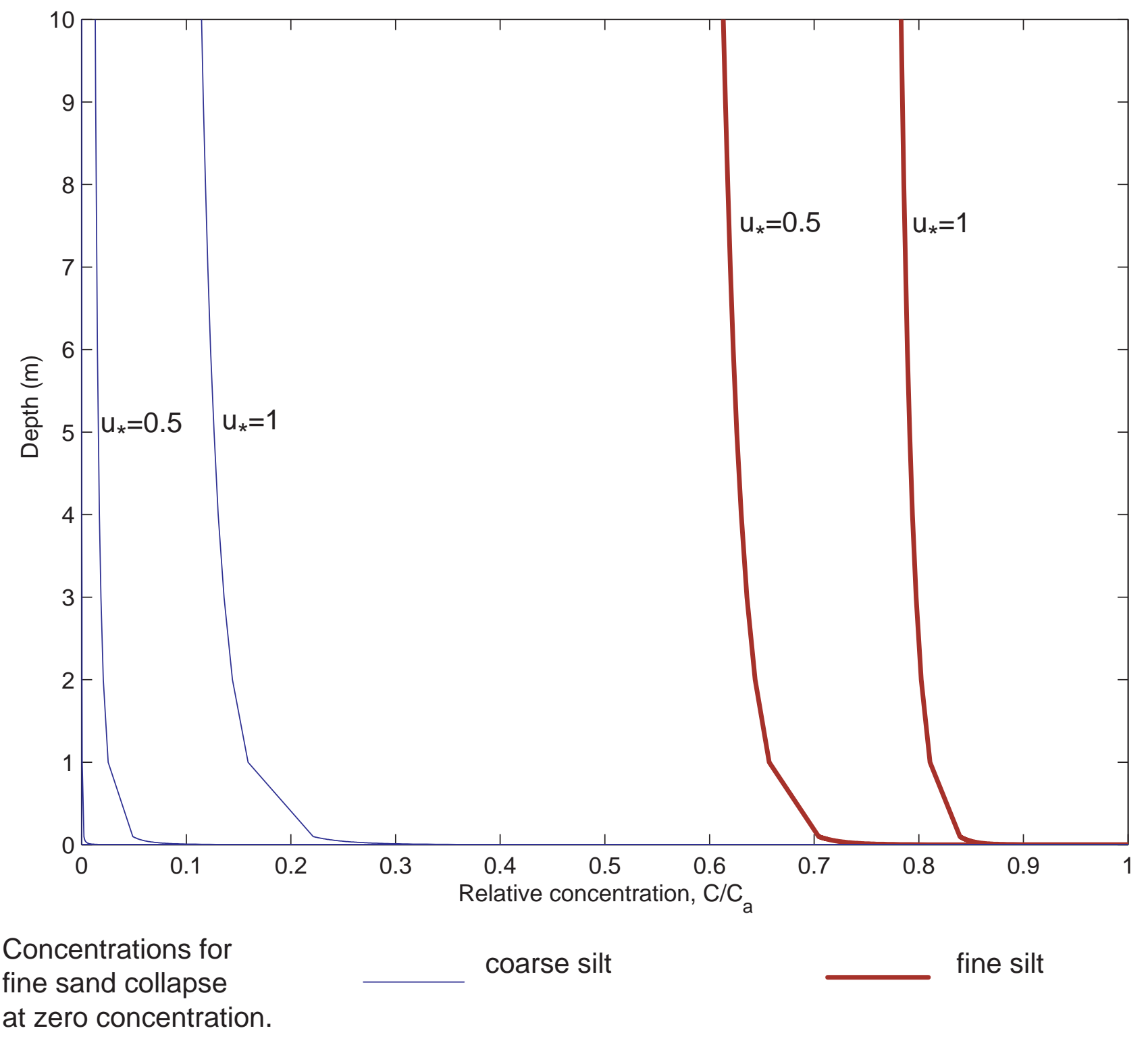

Figure 5. Modeled suspended sediment concentration profiles. Significant amount of fine silts, once resuspended from the bottom, may reach $10 \mathrm{mab}$, where the lowest instrument package was located. 


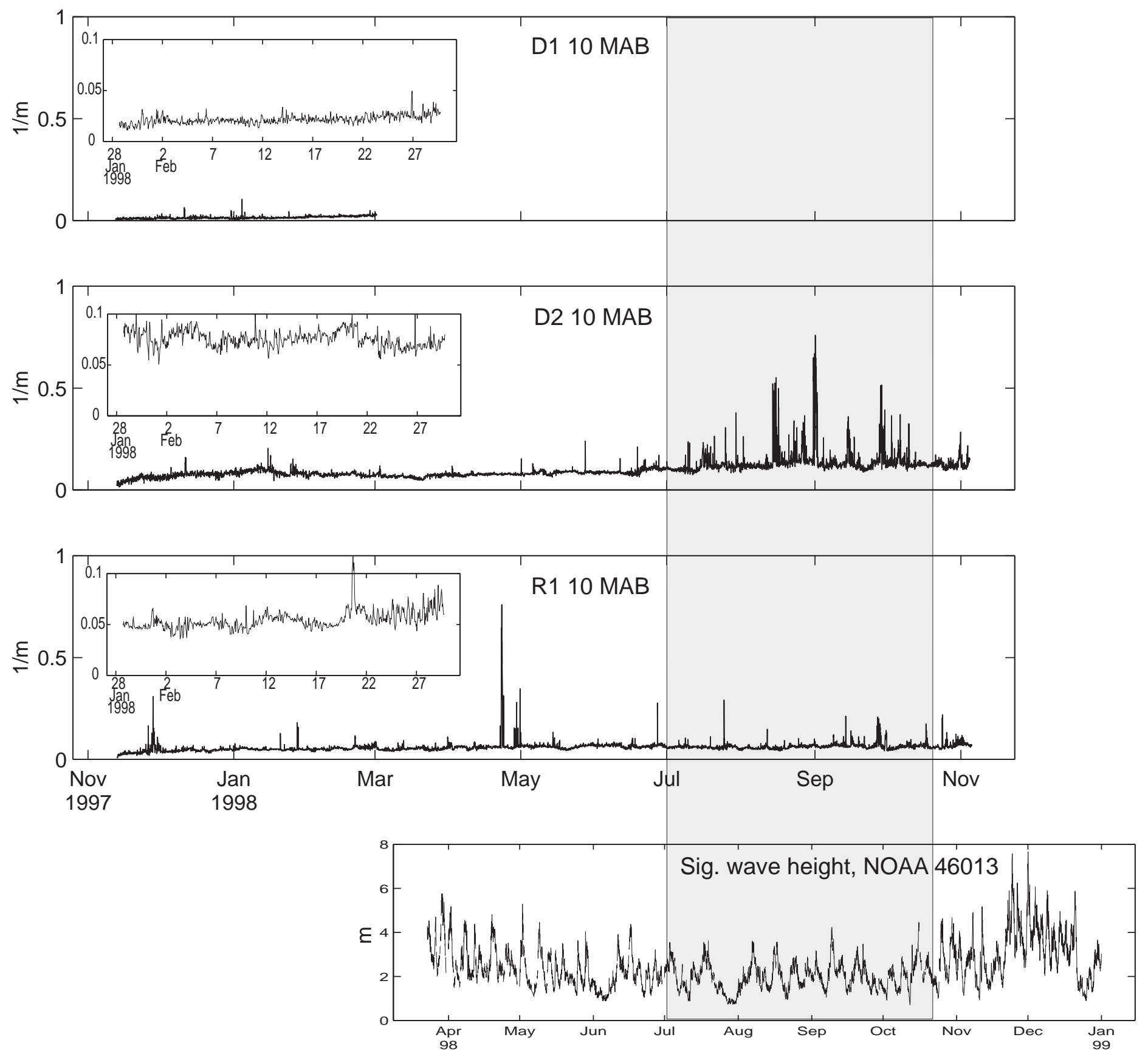

Figure 6. Hour-averaged light attenuation measured at $10 \mathrm{mab}$ at the three moorings. The shaded area shows the time period when high light attenuations correlated with dumping traffic that occurred in low-wave conditions in the summer months. 
two shallower sites occurred more frequently due to their larger magnitudes of tidal current measured near the bed.

The hour-averaged transmissometer data are plotted in Figure 6. The transmissometer on Mooring D1 failed after March 1998 due to severe corrosion, but transmissometers on Moorings D2 and R1 successfully recorded data during the full deployment. There is very little correlation between current speed (or bed-shear stress) and light attenuation measured at $10 \mathrm{mab}$ at any of the three sites, implying that the light-attenuation signals were not caused by resuspension even if bed resuspension occurred. However, there seems to be an inverse correlation between the light attenuation at Mooring D2 and the wave height measured at NDBC 46031 (Figure 6). Note that the high values of attenuation were not found at Mooring R1.

\subsection{Geological characteristics of material captured by the sediment traps}

The grain-size distributions of the trap samples and a sea-floor sample taken from the vicinity of Mooring D1 (Navy-103 site) (SAIC, 1991) are plotted in Figure 3b and listed in Table 12. The sand percentages in trap samples many hundreds of meters above the sea floor at Moorings D1 and D2 were unusually high and orders of magnitude greater than that of the seafloor sediment. The sand percentage at the Mooring D2 top trap was more than 38\%, highest among the four traps, and even higher than the percentages of silt or clay in the trap. The sand percentages in the other 3 traps ranged from $6 \%$ to $21 \%$. In comparison, the percentage of sand in the sea-floor material was between $0.8 \%$ to $1.4 \%$ (SAIC, 1991).

The bottom trap on Mooring D1 collected twice as much sediment as either the top or the middle trap on the same mooring. The sediment texture in the Mooring D1 bottom trap also appeared different from that in the top and middle traps. The sediment composition was finer and much more similar to that of bottom sediments in the region (Figure 3b). Given that the bottomstress calculations show that fine materials can be resuspended at least to 10 mab at this site, it is likely a fair portion of material in this near-bottom trap was resuspended from the sea bed. Bottom-stress estimates also suggest that bottom resuspension events at Moorings D2 and R1 occurred more frequently than at Mooring D1, due to their larger magnitudes of tidal current measured near the bed. Hence, we expect that the sediment volumes in the near-bed traps at Moorings D2 and R1 would have been larger than the volume found in the trap at Mooring D1.

\subsection{Transport of suspended material by currents in this region of the slope}

The observed subtidal and mean flow patterns suggest that material suspended in the very-near-surface layers would tend to move along the slope toward the northwest, but would be dispersed in both the along- and cross-slope direction as it moved along the slope. As the suspended material fell further from the surface layers, the fluctuations in the along-slope flow would move the suspended material back and forth parallel to the isobaths, but if this material remained suspended over the year, there would be little net movement in the center of mass of the suspended material because the mean currents are insignificant at these depths. In addition, once the suspended material fell below 300-400 m, the cross-slope movement of the suspended material would be fairly weak and random with location as the subtidal cross-slope flow patterns are uncorrelated at these depths. At these lower depths, the cross-slope component of the tidal field would tend to move suspended material back and forth across the isobaths, causing a small 
Table 12. Grain size and TOC distributions in sediment-trap material. There was not enough material in the top trap on Mooring D1 to allow an analysis for percentage of organic matter. The middle trap on Mooring D2 was recovered, but probably lost its contents on recovery.

\begin{tabular}{||l|l|c|c|c|c|c|c||}
\hline \multicolumn{2}{|c|}{} & $\begin{array}{c}\text { Volume } \\
\left(\mathbf{c m}^{\mathbf{3}}\right)\end{array}$ & $\begin{array}{c}\text { \% of } \\
\text { sands }\end{array}$ & $\begin{array}{c}\text { \% of } \\
\text { silts }\end{array}$ & $\begin{array}{c}\text { \% of } \\
\text { clay }\end{array}$ & $\begin{array}{c}\text { \% } \\
\text { organic }\end{array}$ & $\begin{array}{c}\text { \% } \\
\text { TOC }\end{array}$ \\
\hline \hline \multirow{3}{*}{ D1 } & Top & 184 & 10.2 & 66.8 & 23.0 & - & 2.4 \\
\cline { 2 - 8 } & Middle & 164 & 20.5 & 55.2 & 24.2 & 7.9 & 2.3 \\
\cline { 2 - 8 } & Bottom & 359 & 6.1 & 62.3 & 31.6 & 7.6 & 2.5 \\
\hline \multirow{3}{*}{ D2 } & Top & 164 & 38.2 & 36.4 & 25.4 & 16.8 & 4.8 \\
\cline { 2 - 9 } & Middle & - & - & - & - & - & - \\
\cline { 2 - 9 } & Bottom & - & - & - & - & - & - \\
\hline \multirow{3}{*}{ R1 } & Top & - & - & - & - & - & - \\
\cline { 2 - 9 } & Middle & - & - & - & - & - & - \\
\cline { 2 - 9 } & Bottom & - & - & - & - & - & - \\
\hline Navy-103* & & - & 1.4 & 70.6 & 28.0 & - & 2.8 \\
\hline \hline
\end{tabular}

* Listed values are from station E-7 of the Navy-103 site study. See SAIC (1991) for more details. 
cross-slope diffusion of the suspended material, but resulting in no net cross-slope movement. Once suspended material at sites east of the disposal site reached depths within $50 \mathrm{~m}$ of the sea floor, at sites near Mooring D1, it would tend to move down the canyon toward the disposal site. Hence, the fine fraction of the dredged material released from the barges at the disposal site that tends to settle slowly would be deposited in an ellipse elongated in the along-slope direction with the center of mass at or just to the northwest of the disposal site. Once the material settled on the sea floor, most of it would remain there. Even if it were occasionally resuspended, as is suggested above, it would remain in a bottom boundary layer and be dispersed along the sea floor. It could not be resuspended high enough to reach the depth of the continental shelf. The only material carried by currents that could enter the Gulf of the Farallones National Marine Sanctuary would be the fine fraction in the near-surface layers that tends either not to settle, or to settle very slowly, in the water column. Again, since the mean cross-slope flows are weak and have no stable direction, the percentage of suspended material that could be carried into the sanctuary, which is about $10 \mathrm{~km}$ from the disposal site, should be small.

However, this does not mean that dredged material does not enter the sanctuary. The top and middle traps on Moorings D1 and D2 did contain a fair percentage of sand. Even fine sand, which requires a bed-shear stress of $1.02 \mathrm{dyne} / \mathrm{cm}^{2}$ to be resuspended from the sea floor (Gardner, 1989), did not appear to be resuspended even $10 \mathrm{~m}$ above the sea floor at Mooring D1, even if one used the highest possible roughness $\left(\mathrm{k}_{\mathrm{b}}=1 \mathrm{~cm}\right)$ for the region. Hence, fine sand could not be resuspended 1000-2000 $\mathrm{m}$ above the sea floor and be captured by the near-surface traps on Moorings D1 and D2.

However, these traps did contain fine sand. Traps on both Moorings D1 and D2 were located under the standard paths where barges carry dredged sediments to the disposal site. It is interesting that the surface and middle traps on the reference mooring (R1) collected no significant material. Mooring R1 was out of the region barges transit. The high sand content in the traps on Moorings D1 and D2, especially in the near-surface traps, suggest that dredged material is spilling from the barges as they transit to the disposal site. The material in the upper traps at D1 and D2 had slightly different percentages of sand, silt, and clay. This is probably because material is dredged from numerous locations in San Francisco Bay (SAIC, 1991) and because barges take different routes to the dumpsite (Ota, personal communication, 2000). Hence, the material in different traps may have come from barges that contained material from a variety of locations.

The inverse correlation between the transmissometer data at Mooring D2 and offshore wave height support our inference that sand-sized sediment in the surface traps originated from leaky barges. Barge traffic occurs most often in the calm summer months, when waves are lower. During stormy winter months, when barge traffic is light or absent, there were relatively few high values for the attenuation coefficient.

There appears to be one contradiction to the above explanation of the inverse correlation between the transmission signal and surface wave amplitudes: the collecting tube in the middle trap on Mooring D2 was found empty (only with clear water) at recovery. If the material leaked from the barges could reach the transmissometer at $1180 \mathrm{~m}$, some of this fall-out material should have been collected in the middle trap located at $385 \mathrm{~m}$. There are at least three possible scenarios: 1) The interpretation of the inverse correlation is incorrect; 2) the opening of the middle sediment trap was blocked over the whole deployment so no sediment could enter the trap; or 3) while still in the water, the sediment trap was accidentally reversed and therefore the collected material in the trap was lost at recovery. After careful examination of the tube, it 
appears scenario 3 is the most likely explanation based on circumstantial evidence. There is a Teflon ${ }^{\circledR}$ dispenser inside the middle trap on Mooring D2 that dumps Teflon ${ }^{\circledR}$ beads into the trap every 21 days. Because the chance of both the trap-opening blockage and a Teflon ${ }^{\circledR}$ dispenser malfunction is minimal, there should have been Teflon ${ }^{\circledR}$ beads at the bottom of the tube, even if no sediment particles actually entered the trap. At recovery, nothing but clear water was found in the collecting tube of the middle trap on Mooring D2. We therefore assume that all material collected in the Mooring D2 mid-depth trap was lost at recovery.

\subsection{Trace-metal geochemistry}

\subsubsection{Trace-metal geochemistry-sediments}

Compared with sediment collected from Mooring D2 (top trap), sediments collected from traps on Mooring D1 typically had higher concentrations of trace metals (Table 13). In particular, concentrations of $\mathrm{Co}, \mathrm{Cr}, \mathrm{Mn}, \mathrm{Pb}$, and $\mathrm{V}$ were as much as 2-4 times greater in sediment from Mooring D1 than in sediment from Mooring D2. Concentrations of As, $\mathrm{Hg}$, and Zn did not exhibit such disparity between the two sites. In contrast, the highest $\mathrm{Sr}$ concentration was measured in sediment from the Mooring D2 top trap. This sample also had the highest TIC content (Table F-1), which may account for the abundance of Sr. The TOC content measured in the Mooring D2-top sediment sample (4.83 wt.\%) is also greater than any TOC concentration measured in sediments collected from the Mooring D1 traps, where TOC contents ranged from 2.34-2.53 wt.\%.

In addition to the horizontal gradients in sediment composition between the two mooring sites, there were also vertical gradients in sediment composition for several trace metals. For example, Cd concentrations in sediment from Mooring D1 (top) and Mooring D2 (top) traps measured 1.9 and $1.8 \mu \mathrm{g} / \mathrm{g}$ dry wt. sediment, respectively. The Cd concentration in sediment from the Mooring D1 middle trap measured $1.2 \mu \mathrm{g} / \mathrm{g}$ dry wt. sediment, and the bottom-most trap from this mooring collected sediment with significantly lower levels of Cd (0.4-0.7 $\mu \mathrm{g} / \mathrm{g}$ dry wt. sediment). The highest concentrations for $\mathrm{Co}, \mathrm{Hg}$, and $\mathrm{Pb}$ were also found in sediments from the top trap from Mooring D1. In contrast, the highest Ba concentrations, (08-386 $\mu \mathrm{g} / \mathrm{g}$ dry wt. sediment) were measured in sediments collected from the deepest trap Mooring D1 (bottom). Barium concentrations were roughly 2-3 times lower in sediments collected from traps positioned higher up in the water column. There was no vertical gradient in TOC content present among the sediments collected from Mooring D1.

The trace-metal concentrations measured in the sediment samples recovered from Moorings D1 and D2 compare favorably with sediment geochemistry reported in other studies of the area (Table 13). In particular, concentrations of $\mathrm{As}, \mathrm{Cd}, \mathrm{Co}, \mathrm{Mn}, \mathrm{Mo}, \mathrm{Pb}$, and $\mathrm{Zn}$ in sediments from these moorings are similar to mean concentrations calculated for data reported by Jones and others (2001). In their study, Jones and others (2001) collected surficial grab samples of benthic sediments taken from several sites near Mooring D2 location. Jones and others (2001) also reported significantly greater concentrations of $\mathrm{Ba}, \mathrm{Cr}, \mathrm{Sr}$, and $\mathrm{V}$, which are known lithophilic elements, than those measured in this study. However, the Jones and others (2001) study utilized a $\mathrm{HNO}_{3}-\mathrm{HClO}_{4}-\mathrm{HF}$ digestion technique (as described in Briggs and Meier, 1999), which is more effective at liberating metals associated with silicate lattices than the $\mathrm{HNO}_{3}$ 
Table 13. Comparison of trace-metal concentrations in sediment samples collected from mooring sediment traps (this study) with data from previously published studies. Trace-metal concentrations are expressed in terms of $\mu \mathrm{g} / \mathrm{g}$ dry wt. sediment. Total organic carbon (TOC) concentrations are given in wt. \% dry sediment. Other data from: [A] SAIC (1991) average metal concentrations in sediment near Farallon Islands (proposed Navy 103 site); [B] Meador and others (1998) concentrations in Farallon Islands sediment that are considered above baseline; [C] Jones and others (2001) average values for grab samples of benthic sediment collected near Mooring D2; [D] average values calculated for the surficial sediment $(0-1 \mathrm{~cm})$ samples from Bothner and others (1998) collected from the EPA reference site off the Farallon Islands; [D] values from Bothner and others (1998) normalized to respective silt+clay contents; [E] mean concentrations averaged from cores CB90-9, CB90-12, and RB92-3 - for San Francisco Bay (SFB) sediment from Hornberger and others (1999).

\begin{tabular}{|c|c|c|c|c|c|c|c|c|c|c|c|c|c|}
\hline \multirow[t]{2}{*}{ Source } & \multicolumn{7}{|c|}{ This Study } & {$[\mathrm{A}]$} & {$[\mathrm{B}]$} & {$[\mathrm{C}]$} & [D] & [D]-norm & {$[\mathrm{E}]$} \\
\hline & \multicolumn{7}{|c|}{$\begin{array}{l}<63 \mathrm{~mm} \text { fraction } \\
\text { HNO3 digestion }\end{array}$} & & $\begin{array}{l}\text { Total sediment } \\
\text { HNO3-HCl-HF }\end{array}$ & $\begin{array}{c}\text { Not specified } \\
\text { HNO3-HClO4-HF }\end{array}$ & $\begin{array}{l}\text { Total } \\
\text { sediment }\end{array}$ & to $<63 \mathrm{~mm}$ & $\begin{array}{c}<64 \mathrm{~mm} \\
\text { HNO3-digestion }\end{array}$ \\
\hline \multirow[t]{2}{*}{$\mathrm{n}:$} & 1 & 1 & 1 & 1 & 1 & 1 & 6 & $\mathrm{x}$ & 1 & 25 & 7 & 7 & $\mathrm{X}$ \\
\hline & D1T-1 & D1M-1 & D1B-1 & D1B-2A & D1B-3 & D2T-1 & Mean & $\begin{array}{l}\text { Farallon } \\
\text { Islands }\end{array}$ & $\begin{array}{l}\text { Farallon } \\
\text { Islands }\end{array}$ & $\begin{array}{c}\text { Near Mooring } \\
\text { D2 }\end{array}$ & $\begin{array}{c}\text { EPA } \\
\text { reference } \\
\text { site }\end{array}$ & $\begin{array}{c}\text { EPA } \\
\text { reference } \\
\text { site }\end{array}$ & SFB \\
\hline $\begin{array}{l}\text { TOC } \\
\text { (wt.\%) }\end{array}$ & 2.36 & 2.34 & 2.53 & 2.38 & 2.5 & 4.83 & 2.82 & 3.49 & $\mathrm{X}$ & $\mathrm{x}$ & 1.59 & 2.19 & $\mathrm{x}$ \\
\hline As & 6.8 & 6.3 & 5.1 & 6.7 & 5.7 & 4.7 & 5.9 & 4.6 & $\mathrm{x}$ & 6.81 & 2.14 & 2.96 & $\mathrm{x}$ \\
\hline $\mathbf{B a}$ & 134 & 161 & 386 & 308 & 367 & 153 & 252 & $\mathrm{x}$ & $\mathrm{x}$ & 597 & $\mathrm{x}$ & $\mathrm{x}$ & $\mathrm{x}$ \\
\hline Cd & 1.9 & 1.2 & 0.5 & 0.7 & 0.4 & 1.8 & 1.1 & 0.31 & 3.3 & 1.33 & 0.46 & 0.63 & $\mathrm{x}$ \\
\hline Co & 12.7 & 9.5 & 6.6 & 10.0 & 8.9 & 3.2 & 8.5 & $\mathrm{x}$ & $\mathrm{x}$ & 9.39 & $\mathrm{X}$ & $\mathrm{x}$ & $\mathrm{X}$ \\
\hline $\mathrm{Cr}$ & 80.6 & 51.8 & 63.3 & 81.3 & 79.2 & 26.7 & 63.8 & 100 & $\mathrm{x}$ & 134 & 54.46 & 75.7 & 102 \\
\hline Hg & 0.4 & 0.3 & 0.3 & 0.3 & 0.3 & 0.2 & 0.3 & 0.16 & $\mathrm{x}$ & $\mathrm{x}$ & 0.11 & 0.16 & $\mathrm{X}$ \\
\hline Mn & 305 & 155 & 184 & 280 & 254 & 95 & 212 & 313 & $\mathrm{X}$ & 343 & $\mathrm{x}$ & $\mathrm{x}$ & 304 \\
\hline Mo & 2.1 & 1.3 & 0.7 & 0.5 & 0.5 & 0.8 & 1.0 & $\mathrm{X}$ & $\mathrm{x}$ & 1.22 & $\mathrm{x}$ & $\mathrm{x}$ & $\mathrm{X}$ \\
\hline $\mathbf{P b}$ & 23.8 & 13.3 & 8.7 & 13.9 & 11.6 & 6.7 & 13.0 & 10.4 & $\mathrm{X}$ & 11.23 & 4.36 & 6.13 & $\mathrm{X}$ \\
\hline $\mathbf{S r}$ & 119 & 175 & 154 & 110 & 103 & 268 & 155 & $\mathrm{X}$ & $\mathrm{X}$ & 348 & $\mathrm{X}$ & $\mathrm{X}$ & $\mathrm{X}$ \\
\hline $\mathbf{V}$ & 61.8 & 40.6 & 41.5 & 54.6 & 47.2 & 22.9 & 44.8 & $\mathrm{x}$ & $\mathrm{X}$ & 99 & $\mathrm{X}$ & $\mathrm{X}$ & 84.7 \\
\hline $\mathbf{Z n}$ & 136 & 77 & 416 & 104 & 109 & 63 & 151 & 98 & $\mathrm{X}$ & 73.7 & 54.43 & 76.11 & X \\
\hline
\end{tabular}


digestion used in this study. The QA/QC analyses conducted as part of this study showed that trace metal recoveries for Ba, Cr, Sr, and V (among others) from SRM 2704 (Buffalo River sediment) were significantly lower than the certified concentrations. Recoveries of these four elements from SRM 2704 ranged from 23 to $72 \%$ of certified values. This "silicate matrix effect" (sme) has been noted in previous sediment geochemistry studies.

The trace metal concentrations in sediments collected from the mooring sediment traps are generally greater than those measured in benthic sediments collected from the EPA reference site, Mooring R1 (Table 13) (Bothner and others, 1998). Bothner and others (1998) used a digestion method $\left(\mathrm{HNO}_{3}-\mathrm{HCl}\right)$ similar to the one used in this study, but conducted their digestions on whole sediment, not sieved sediment as in this study. However, even when their trace metal concentrations are normalized to the corresponding silt+clay contents, the concentrations of $\mathrm{As}, \mathrm{Hg}$, and $\mathrm{Pb}$ are still greater in the mooring sediment trap samples (this study) than in the normalized-samples from the EPA reference site. Concentrations of $\mathrm{Cd}$ in sediment samples from the uppermost mooring sediment traps are also greater than $\mathrm{Cd}$ concentrations in the silt+clay content-normalized sediments from Bothner and others (1998) study of the EPA reference site. A study of an offshore dumping site in the North Sea reported similar gradients for $\mathrm{Cd}$ and $\mathrm{Hg}$ concentrations in normalized sediments from the dump and reference areas (Stronkhorst and others, 2003).

The amount of trace metals measured in sediment does not necessarily reflect the risk to biota, as the amount of bioavailable metal in sediment can range from 0 to $100 \%$ of the corresponding concentration in sediment. Long and others (1995) attempted to correlate toxicity test results/organism survival rates with trace-metal content in sediments. This study produced two guidelines -based on sediment geochemistry- by which to evaluate potential sediment toxicity. The two guidelines are classified as Effects Range-Low (ERL) and Effects Range-Median (ERM), corresponding to the lower 10th percentile and 50th percentile of the measured distribution of effects documented in biota.

In the absence of direct toxicity tests or measurement of the biologically available portion of metals, the total metal content can provide a preliminary summary guideline by which to evaluate sediments for potential toxicity. Trace-metal concentrations measured in sediments collected from the mooring sediment traps are compared with the ERL and ERM guidelines in Table 14. The average of the samples from Mooring D1 $(n=5)$ is presented in this table. Data from the Mooring D2 sediment sample is listed separately, owing to the variation in trace-metal content between the two stations. At Mooring D2 (closest to shore), two metals exceeded ERL guidelines: $\mathrm{Cd}$ and $\mathrm{Hg}$. No metals exceed ERM guidelines at Mooring D2.

At Mooring D1, the mean $\mathrm{Hg}$ and Zn concentrations exceeded ERL guidelines. The concentration of $\mathrm{Cd}$ in individual sediment samples recovered from the upper two traps of Mooring D1 are greater than or equal to the ERL threshold.

\subsubsection{Trace-metal geochemistry-mussels}

Trace-metal concentrations in mussels generally were similar among Moorings D1, D2, and R1 (Table 15). Of the 13 metals analyzed, only Al, Mn, Se, and Sn appear to be present at higher concentrations in mussels deployed with Moorings D1 and D2 than in mussels deployed with Mooring R1. The disparity in Al concentrations may reflect increased uptake of fine particles; i.e., clay-size materials, by mussels at Moorings D1 and D2. Given the use of Sn as an 
Table 14. Comparison among trace-metal concentrations in sediments collected from mooring sediment traps and sediment-toxicity guideline values. All concentrations given in terms of $\mu \mathrm{g}$ metal/g dry wt. sediment. Effects Range-Low (ERL) and Effects Range-Median (ERM) values from Long and others (1995).

\begin{tabular}{|ccc|cc|}
\hline & & & \multicolumn{2}{c|}{ This Study } \\
& ERL & ERM & D1 (mean) & D2T \\
\hline As & 8.2 & 70 & 6.1 & 4.7 \\
Cd & 1.2 & 9.6 & 0.9 & 1.8 \\
Cr & 81 & 370 & 71.2 & 26.7 \\
Hg & 0.15 & 0.71 & 0.3 & 0.2 \\
Pb & 46.7 & 218 & 14.2 & 6.7 \\
Zn & 150 & 410 & 168.5 & 63.4 \\
\hline
\end{tabular}

Table 15. Trace-metal concentrations in mussel tissue from moored mussels. All concentrations given in terms of $\mu \mathrm{g}$ metal $/ \mathrm{g}$ dry wt. tissue.

\begin{tabular}{|r|rr|rr|rr|}
\hline Station & \multicolumn{2}{|c|}{ D1 } & \multicolumn{2}{|c|}{ D2 } & \multicolumn{2}{c|}{ R1 } \\
\hline Element & MEAN & STDV & MEAN & STDV & MEAN & STDV \\
\hline \hline $\mathbf{A g}$ & 0.130 & 0.014 & 0.126 & 0.014 & 0.142 & 0.038 \\
$\mathbf{A l}$ & 127 & 48 & 155 & 29 & 53 & 18 \\
$\mathbf{A s}$ & 12.3 & 0.4 & 11.8 & 0.9 & 11.6 & 0.8 \\
$\mathbf{C d}$ & 15.0 & 1.9 & 16.0 & 3.4 & 15.7 & 2.7 \\
$\mathbf{C r}$ & 2.92 & 0.29 & 2.82 & 0.09 & 2.67 & 0.27 \\
$\mathbf{C u}$ & 4.27 & 0.30 & 4.08 & 0.15 & 4.06 & 0.44 \\
$\mathbf{H g}$ & 0.273 & 0.022 & 0.261 & 0.048 & 0.309 & 0.043 \\
$\mathbf{M n}$ & 4.77 & 1.59 & 3.22 & 0.56 & 2.42 & 0.56 \\
$\mathbf{N i}$ & 3.12 & 0.40 & 3.30 & 0.40 & 2.61 & 0.35 \\
$\mathbf{P b}$ & 1.80 & 0.22 & 1.69 & 0.27 & 1.71 & 0.29 \\
$\mathbf{S e}$ & 3.57 & 0.28 & 3.17 & 0.13 & 2.81 & 0.43 \\
$\mathbf{S n}$ & 0.069 & 0.044 & 0.040 & 0.009 & 0.006 & 0.004 \\
$\mathbf{Z n}$ & 189 & 10 & 185 & 6 & 200 & 27 \\
\hline
\end{tabular}


antifouling agent on boats, the variation in Sn content may reflect differences between more heavily-trafficked areas (Moorings D1 and D2) and less-trafficked areas.

\section{SUMMARY}

The patterns in the first two modes for the along-slope flow field suggest that fluctuations in the subtidal currents are correlated across the region in water depths above $1200 \mathrm{~m}$. It is probable that these two modes jointly represent two different processes. The California undercurrent flows over the upper slope off the west coast of the United States. It has a net mean flow toward the northwest. Fluctuation in this flow field reaches well below $500 \mathrm{~m}$ of water depth. During part of the year, the undercurrent dominates the surface flows (Chelton, 1984; Ramp and others, 1997). During other times, it tends to sink lower in the water column, decoupling itself from the surface currents. Hence, the two along-slope modes reflect the spatial changes in this complex flow structure over time. In addition, winds drive the currents along the slope down to water depths of $400 \mathrm{~m}$ (Noble and Ramp, 2000). Both the undercurrent and winddriven flow act to enhance the regional coherence of the along-slope currents over the slope off the Farallon Islands.

The amplitude of the subtidal current fluctuations in water depths less than $100 \mathrm{~m}$ tends to be not only larger than the mean flow, but the amplitude of the along- and cross-slope flows are somewhat similar, even though the along-slope flows do dominate. Hence, as discussed above, although the transport of suspended material in the surface layers tends to be along-slope and toward the northwest, the potential for cross-slope dispersal of suspended material cannot be discounted. Fortunately, most of the dredged material disposed of in the region sinks rapidly out of the surface layers and is not dispersed widely over the region by this process. Only the very fine fraction of the dredged material that remains suspended in the surface waters for time periods of days to weeks has the potential to be transported toward the Gulf of the Farallones National Marine Sanctuary. Since the mean cross-slope flows near the surface in this region are weak and have no stable direction, the percentage of suspended material that could be carried into the sanctuary should be small.

The fluctuating amplitudes of along-slope currents in water depths less than $800 \mathrm{~m}$ also tends to be stronger than the mean flow. Although transport over the slope off shore of the Farallon Islands tends to be northwesterly, the direction of transport can be southeasterly for weeks at a time. Hence material suspended in the water column would be dispersed along the isobaths, but would not tend to preferentially move toward the sanctuary boundaries.

Subtidal currents near the bed or within the submarine canyon tend to be independent from the overlying flow field. This suggests that fluctuations in the near-bed current field have small spatial scales over the measurement region; measurements at one site cannot be used to predict near-bottom flow patterns at a nearby site. However, the energy in these near-bed currents tends to be too small to resuspend fine sand even $10 \mathrm{~m}$ above the bed. Finer material, silts and clays, can be resuspended higher, but if they are deposited in a disposal site deeper than $2000 \mathrm{~m}$, they will not be resuspended high enough to reach the sanctuary boundaries. It is more likely that they will move slowly along the isobaths toward the northwest. Fine material on the seabed in the small canyon east of the disposal site will move down-canyon, toward the disposal site. 
The relatively large percentage of sand-sized material found in the near-surface sediment traps at Moorings D1 and D2 suggests that dredged material is spilling from the barges as they transit to the deep-water disposal site. The inverse correlation between the transmission records at Mooring D2 and the wave climate suggests that material leaks from the large number of barges that pass the site during the relatively calm summer months. Both the observed variations in grain size and chemistry of the sediments caught by these surface traps supports this assumption. This is because the material transported by the barges and caught in the sediment traps is dredged from numerous locations with different sediment types within San Francisco Bay. Note that no material from the barges was captured in the sediment traps at the reference site R1, which lies outside of the barge traffic region.

Even though we had no direct measurements of bottom currents within the disposal site, it is probable that the potential for resuspension of sediments within the site will be even smaller than the resuspension potential measured at Mooring D1, within the submarine canyon. The current pattern in the region suggests that material deposited at the disposal site, if it is resuspended and transported at all, would be transported primarily along the slope toward the northwest.

There are slight elevations in a few of the trace-metal concentrations found in the sediment-trap material, such that these metals exceed the ERL, but not the ERM, guidelines. However, it is not known whether these metals are bioavailable, and hence harmful to the local biota. The slightly elevated trace-metal concentrations in the sediment-trap material compared to local bed sediments also support the assumption that the various sediments in the traps came from San Francisco Bay.

Also, the general similarity among trace-metal concentrations in mussel-tissue samples does not reflect the gradients observed in sediment geochemistry among Moorings D1 and D2 and previous studies of the reference site (Bothner and others, 1998). This possible disparity between sediment geochemistry and mussel-tissue geochemistry underscores the need for more comprehensive characterization of the bioavailable portion of the trace-metal burden associated with sediments and the processes affecting biologic uptake of trace metals within the study area.

\section{Acknowledgements}

The editors and authors thank Gary Ichikawa, of the California State Department of Fish and Game, for his work on the mussel data, as well as Marinna Martini, Jonathan Borden, Richard Rendigs, William Strahle, Joe Newell, and Bob Barton of the U.S. Geological Survey (USGS) Coastal and Marine Geology Team (CMGT), Woods Hole, MA; Marla Stone, Paul Jessen, and Ron Cowen of the Monterey Naval Postgraduate School (NPS), Monterey, CA; and the captain and crew of the R/V Pt. Sur for preparing, deploying, and recovering the many types of instruments used in this project. Curtis Collins, Tarry Rago, and Rob Bourke, NPS, collected CTD profiles during deployment and recovery operations from the Aanderaa current meters and one ADCP. All data from the moored instruments were initially processed by personnel at their respective institutions, under the supervision of Marla Stone and Curtis Collins, NPS, and Frances Lightsom and Marinna Martini of the USGS CMGT, Woods Hole, MA. Kevin Orzech and Juliet Kinney of the USGS CMGT, Menlo Park, CA, further processed the data and created tables and figures. 


\section{REFERENCES}

Abdelrhman, M.A., 1992, Modeling of dredged material disposal in deep ocean environments near San Francisco: model intercomparison and exploration of modeling issues: Prepared for U.S. Environmental Protection Agency, San Francisco, Draft Report, 63 p.

Anderson, N.O., 1974, On the calculation of filter coefficients for maximum entropy spectral analysis: Geophysics, v. 39, p. 69-72.

Bothner, M.H., Gill, P.W., Boothman, W.S., Taylor, B.B., and Karl, H.A., 1998, Chemical gradients in sediment from a U.S. Environmental Protection Agency Reference Site off the Farallon Islands-assessing chemical indicators of dredged material disposal in the deep sea: Marine Pollution Bulletin, v. 36(6), p. 443-457.

Briggs, P.H., and Meier, A.L., 1999, The determination of forty-two elements in geological materials by inductively coupled plasma-mass spectrometry: U.S. Geological Survey Open-File Report 99-166, 15 p.

Chelton, D.B., 1984, Seasonal variability of alongshore geostrophic velocity off central California: Journal of Geophysical Research, v. 89(C3), p. 3473-3486.

Dyer, K.R., and Soulsby, R.L., 1988, Sand transport on the continental shelf: Annual Review of Fluid Mechanics, v. 20, p. 295-324.

Flegal, R.A., 1982, Near shore waste disposal, in Wastes in the ocean, v. VI, B.H. Ketchum (ed.): New York, John Wiley and Sons, Inc.

Foreman, M.G.G., 1977, Manual for tidal heights analysis and prediction: Patricia Bay, Sydney, B.C., Institute of Ocean Sciences, Pacific Marine Science Report 77-10, 97 p.

—, 1978, Manual for tidal currents analysis and prediction: Patricia Bay, Sydney, B.C., Institute of Ocean Sciences, Pacific Marine Science Report 78-6, 70 p.

Gardner, W.D., 1989, Periodic resuspension in Baltimore Canyon by focusing of internal waves: Journal of Geophysical Research, v. 96, p. 5955-5974.

Godin, G., 1972, The analysis of tides: Toronto, University of Toronto Press, 264 p.

Hornberger, M.I., Luoma, S.N., van Geen, A., Fuller, C., and Anima, R., 1999, Historical trends of metals in the sediments of San Francisco Bay, California, in The impact of human activities on sediments of San Francisco Bay, California, A. van Geen and S. Luoma (eds.): Marine Chemistry, v. 64(1-2), p. 7-27.

Jones, D.G., Roberts, P.D., Limburg, J., Karl, H., Chin, J.L., Shanks, W.C., Hall, R., and Howard, D., 2001, Measurements of seafloor radioactivity at the Farallon Islands Radioactive Waste Dump Site, California: U.S. Geological Survey Open-File Report 01$62,40 \mathrm{p}$.

Joreskog, K.G., Klovan, J.E., and Reyment, R.A., 1976, Geological factor analysis: New York, Elsevier, $178 \mathrm{p}$.

Kolak, J.J., Long, D.T., Beals, T.M., Eisenreich, S.J., and Swackhamer, D.L., 1998, Anthropogenic inventories and historical and present accumulation rates of copper in Great Lakes sediments: Applied Geochemistry, v. 13, p. 59-75.

Limeburner, R., 1985, CODE-2, moored array and large-scale data report: Woods Hole Oceanographic Institute Technical Report, WHOI 85-35, 234 p.

Long, E.R., Macdonald, D.D., Smith, S.L., and Calder, F.D., 1995, Incidence of adverse biological effects within ranges of chemical concentrations in marine and estuarine sediments: Environmental Management, v. 19(1), p. 81-97. 
Meador, J.P., Robisch, P.A., Clark, R.C., and Ernest, D.W., 1998, Elements in fish and sediment from the Pacific Coast of the United States: Results from the National Benthic Surveillance Project: Marine Pollution Bulletin, v. 37(1-2), p. 56-66.

Noble, M.A., and Ramp, S.R., 2000, Subtidal currents over the central California slope: Evidence for offshore veering of the undercurrent and for direct, wind-driven slope currents: Deep Sea Research II, v. 47, p. 871-906.

Ramp. S.R., Rosenfeld, L.K., Tisch, T.D., and Hicks, M.R., 1997, Moored observations of the current and temperature structure over the continental slope off central California, 1: A basic description of the variability: Journal of Geophysical Research, v. 102, p. 2287722902.

SAIC, 1991, Biological and sedimentological investigations of the sea floor at the proposed U.S. NAVY 103 ocean disposal site: Prepared for PRC Environmental Management, Inc. Final Report, 96 p.

-, 1992, Modeling potential deposition and water column turbidity for proposed long-term disposal of dredged material at sites off San Francisco, California: Prepared for U.S. Environmental Protection Agency, San Francisco. Draft Final Report, 122 p.

Stronkhorst, J., Ariese, F., van Hattum, B., Postma, J.F., de Kluijver, M., Den Besten, P.J., Bergman, M.J.N., Daan, R., Murk, A.J., and Vethaak, A.D., 2003, Environmental impact and recovery at two dumping sites for dredged material in the North Sea: Environmental Pollution, v. 124, p. 17-31.

Tetra Tech, 1992, Preliminary modeling for the purpose of estimating dredged material accumulations at deep ocean disposal sites off the Farallon Island: Prepared for U.S. Environmental Protection Agency, San Francisco. Final Report, 53 p.

UNESCO, 1991, Processing of oceanographic station data: Paris, Imprimerie des Presses Universitaires de France, 138 p. 
Appendix A.

\section{Hour-averaged currents}



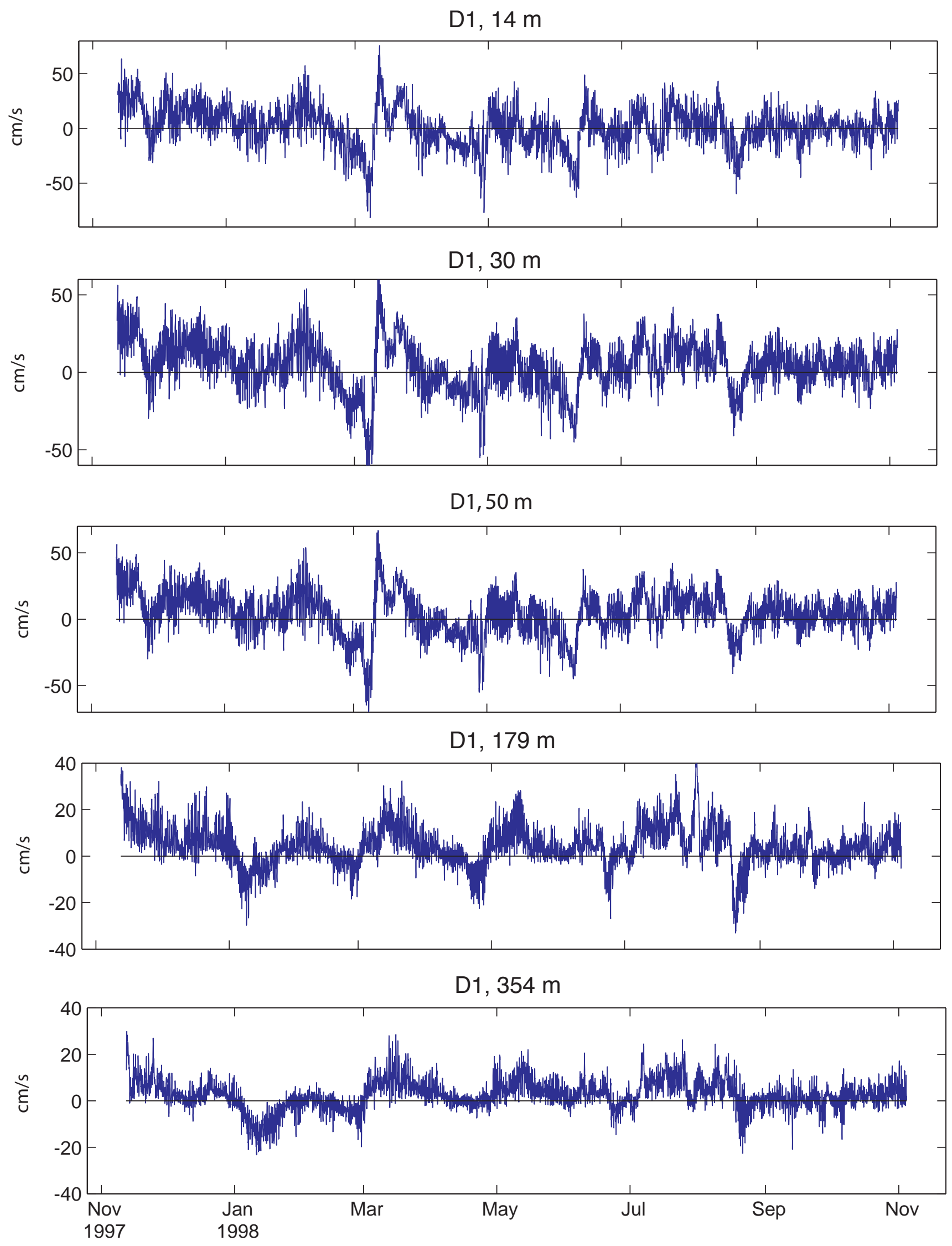

Figure A-1. Hour-averaged along-slope currents (cm/s) at Mooring D1. 
D1, $754 \mathrm{~m}$
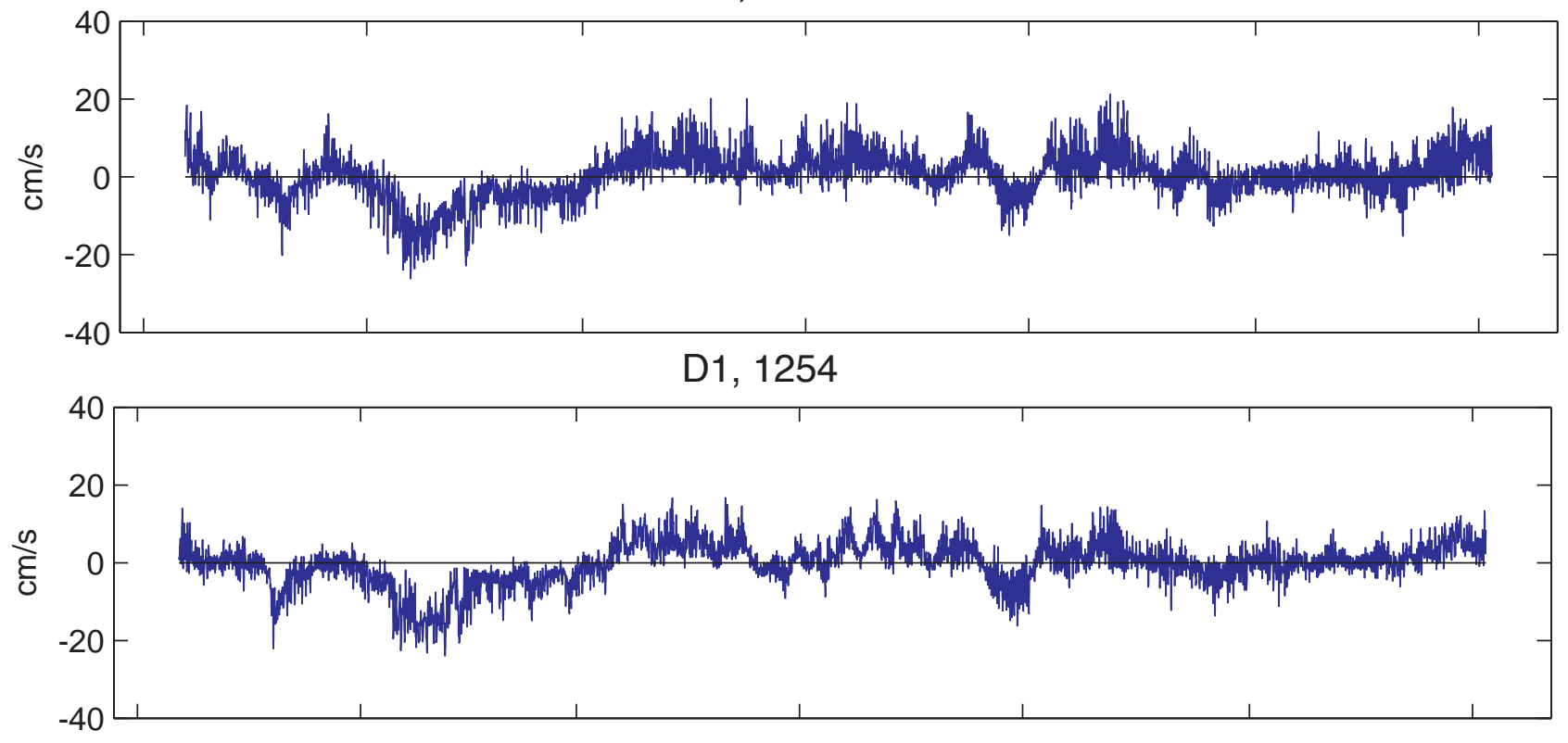

D1, $1954 \mathrm{~m}$

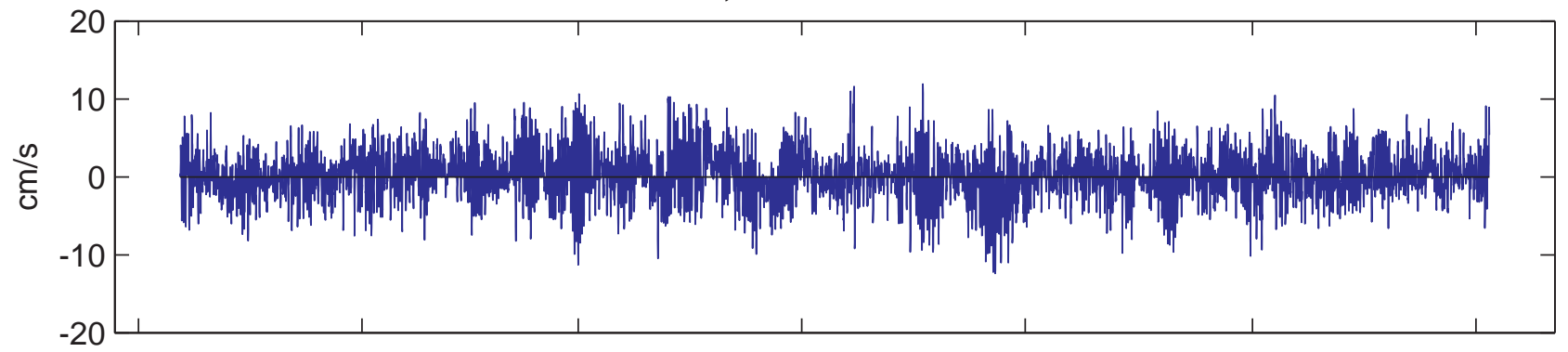

D1, $2354 \mathrm{~m}$

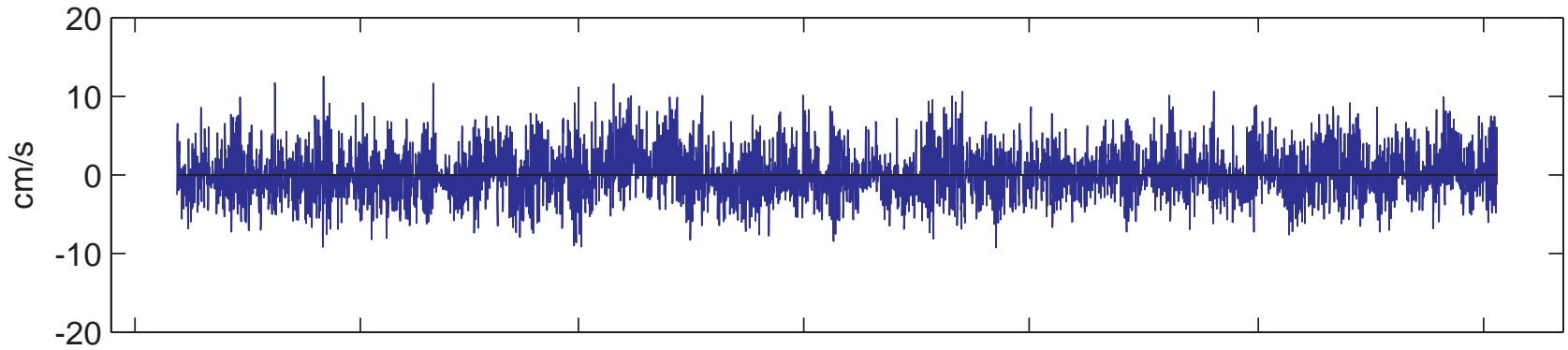

D1, 2394

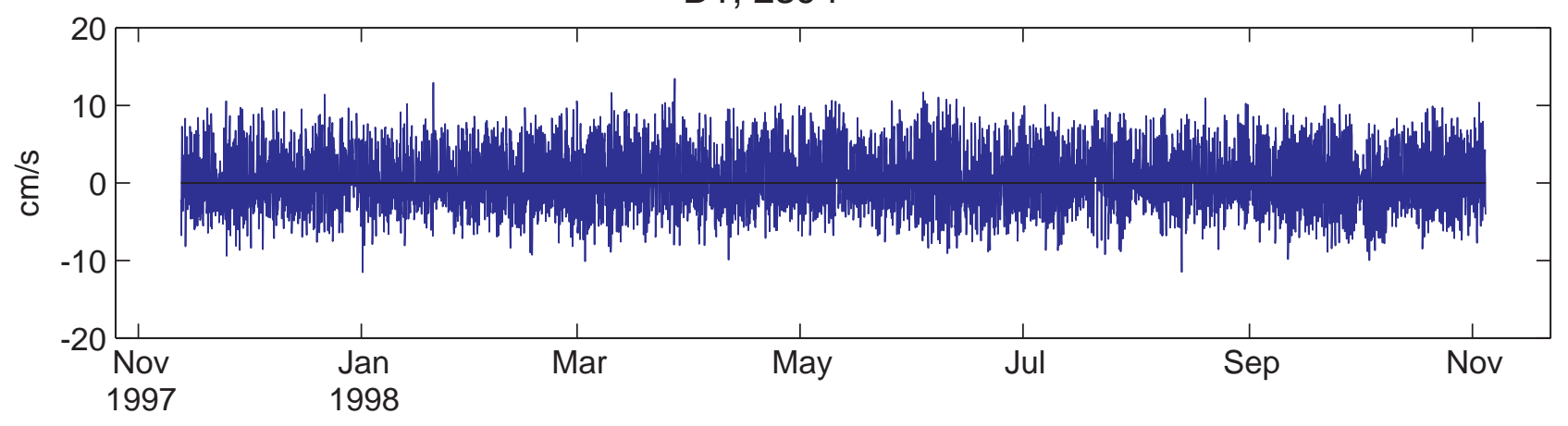

Figure A-1, cont. Hour-averaged along-slope currents $(\mathrm{cm} / \mathrm{s})$ at Mooring D1. 
$\mathrm{D} 2,90 \mathrm{~m}$

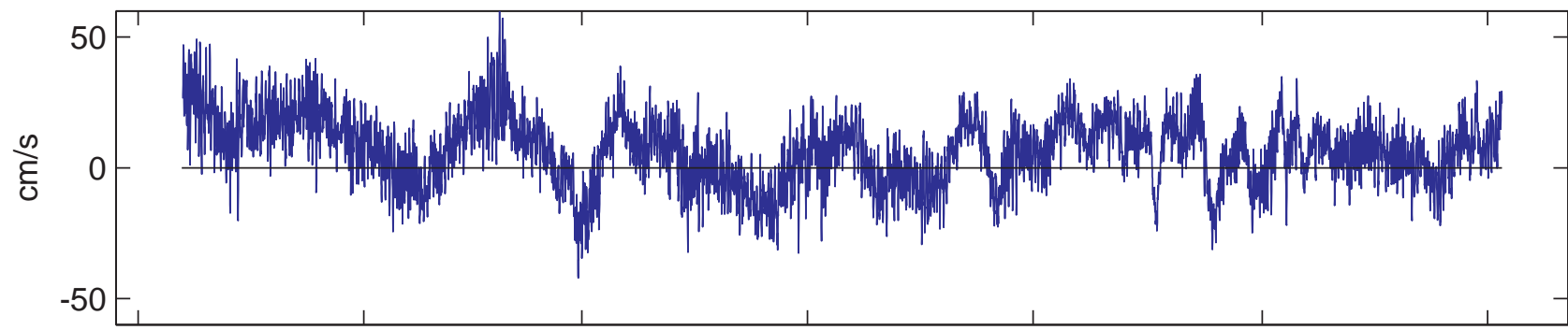

$\mathrm{D} 2,215 \mathrm{~m}$

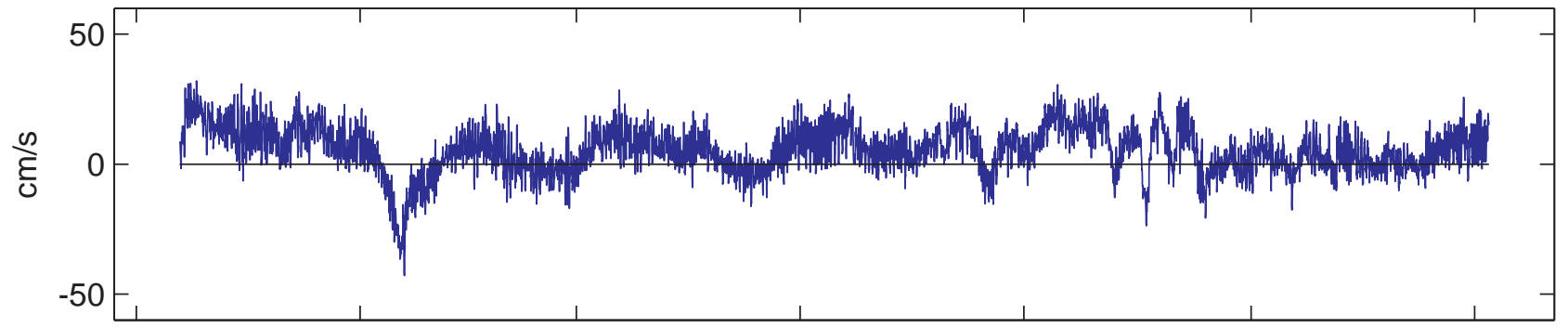

$\mathrm{D} 2,390 \mathrm{~m}$
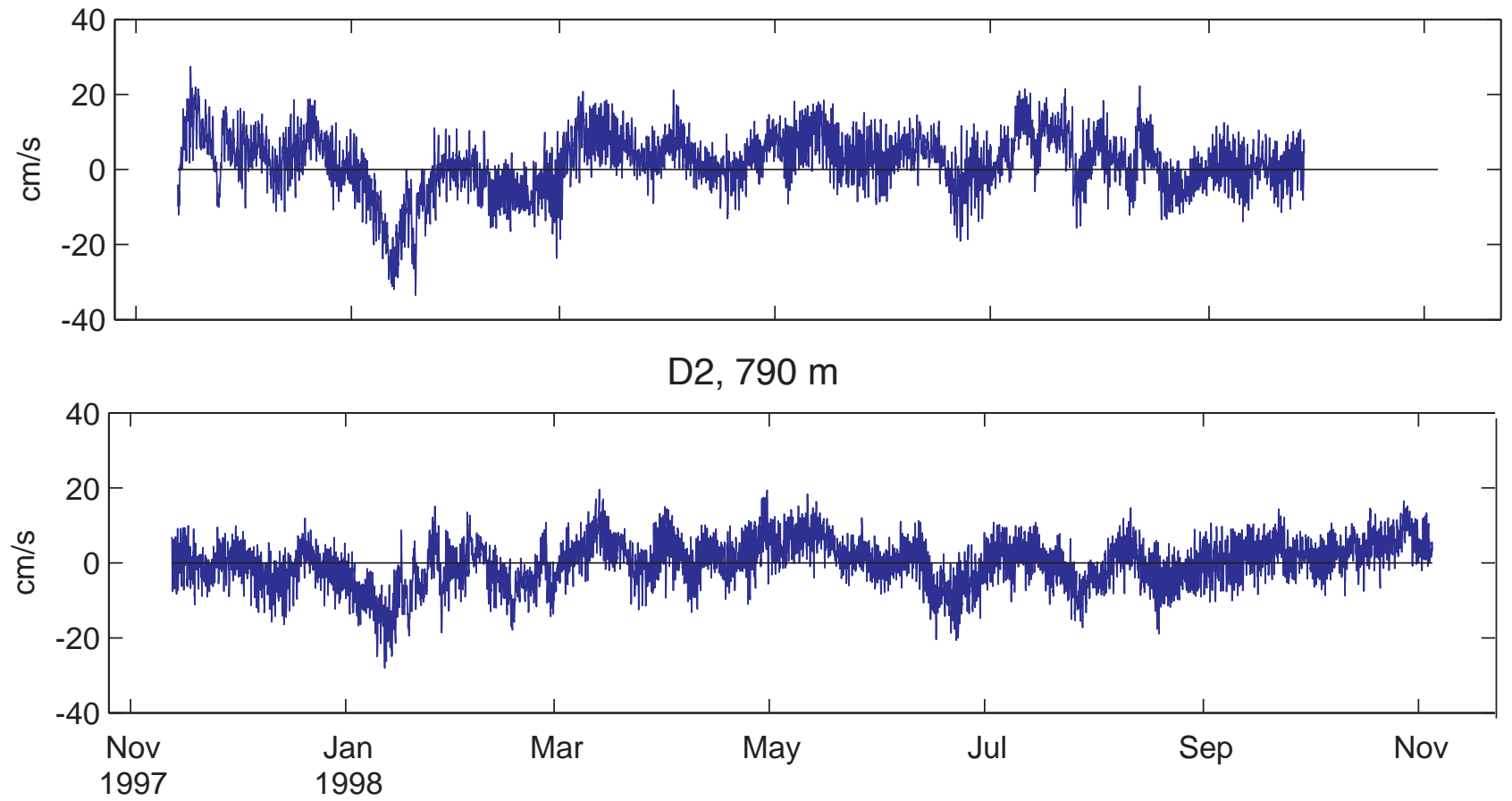

Figure A-2. Hour-averaged along-slope currents $(\mathrm{cm} / \mathrm{s})$ at Mooring D2. 
$\mathrm{D} 2,1140 \mathrm{~m}$
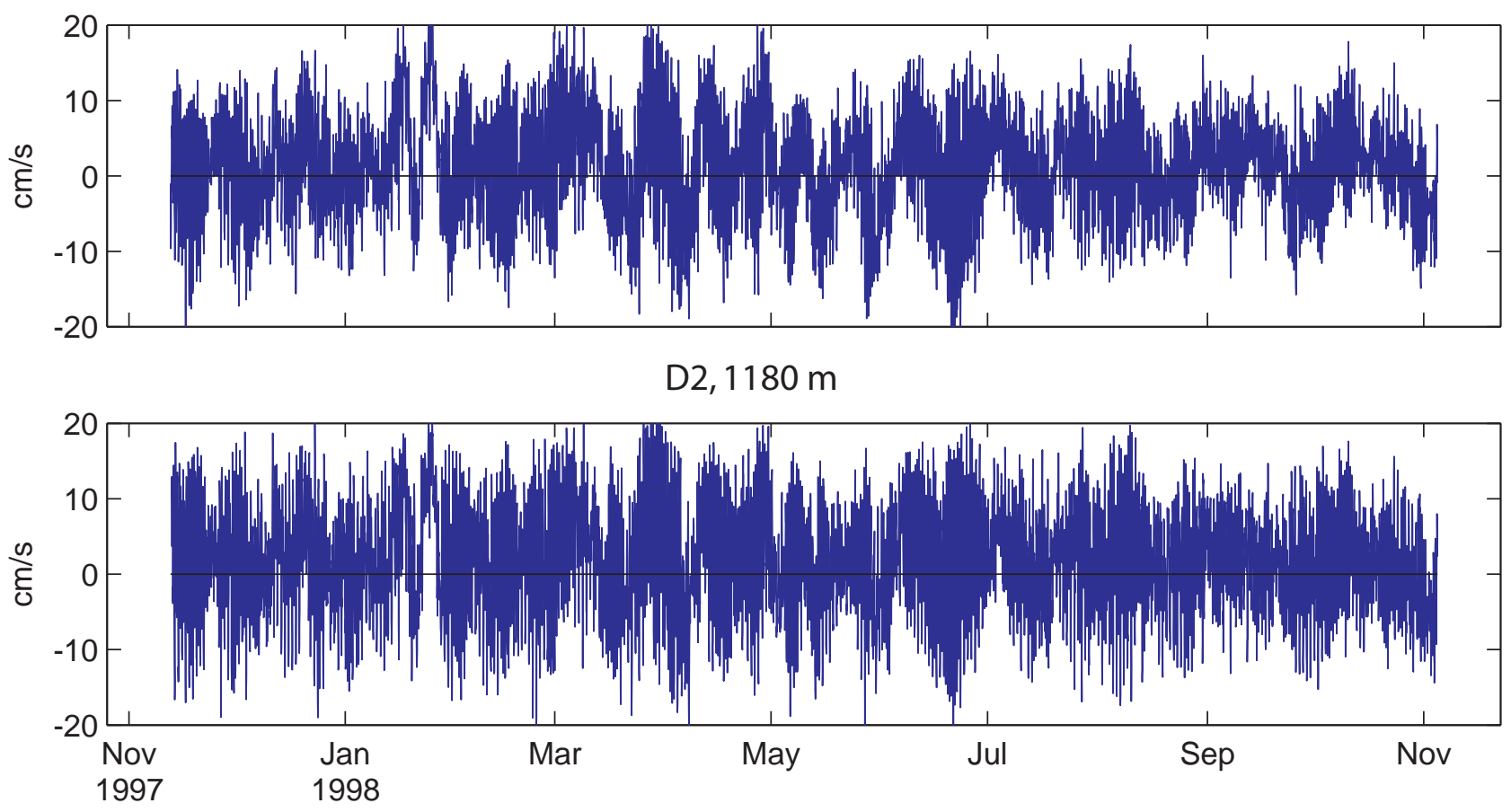

Figure A-2, cont. Hour-averaged along-slope currents $(\mathrm{cm} / \mathrm{s})$ at Mooring D2. 
$\mathrm{R} 1,81 \mathrm{~m}$
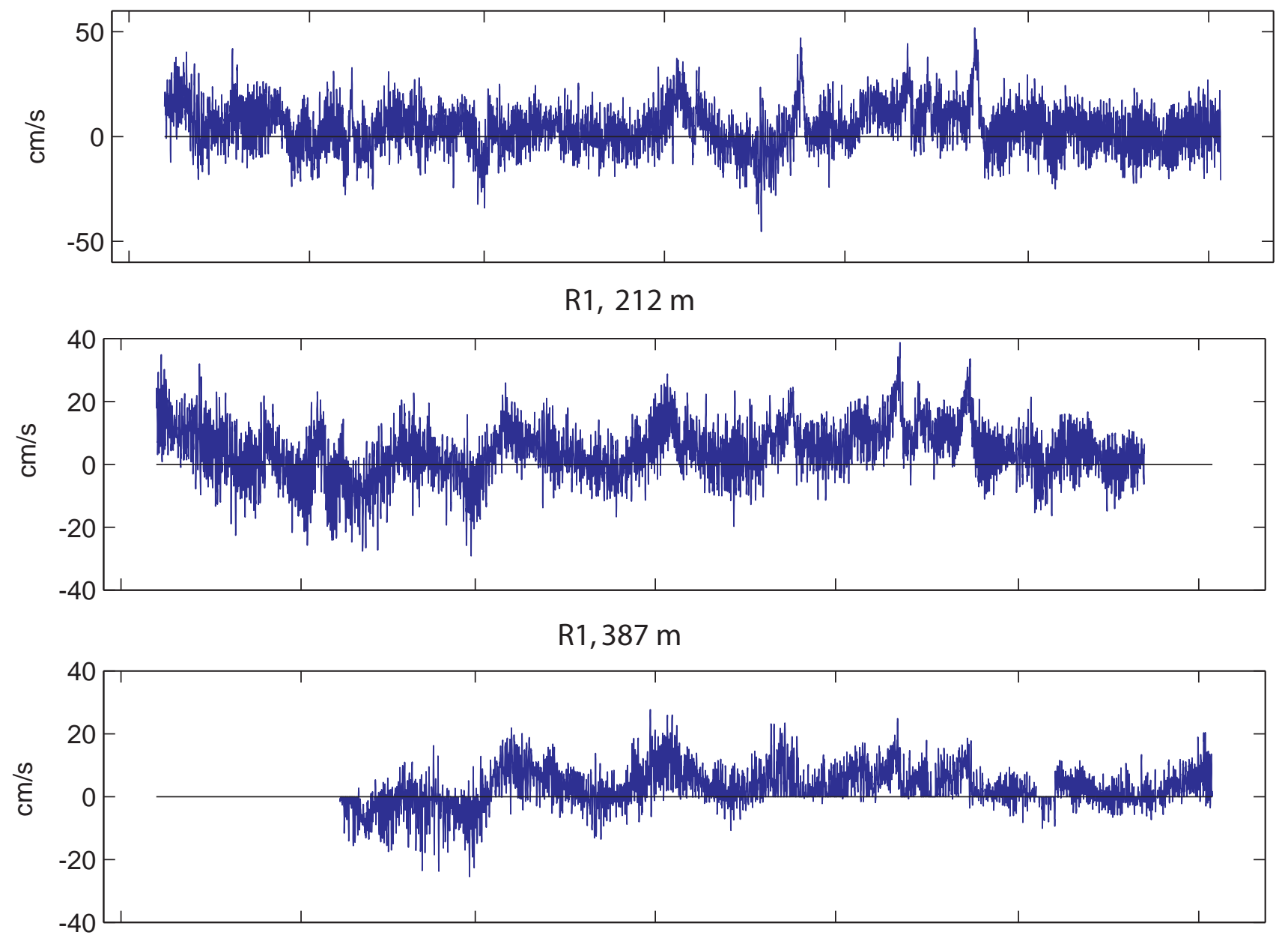

\section{$\mathrm{R} 1,787 \mathrm{~m}$}

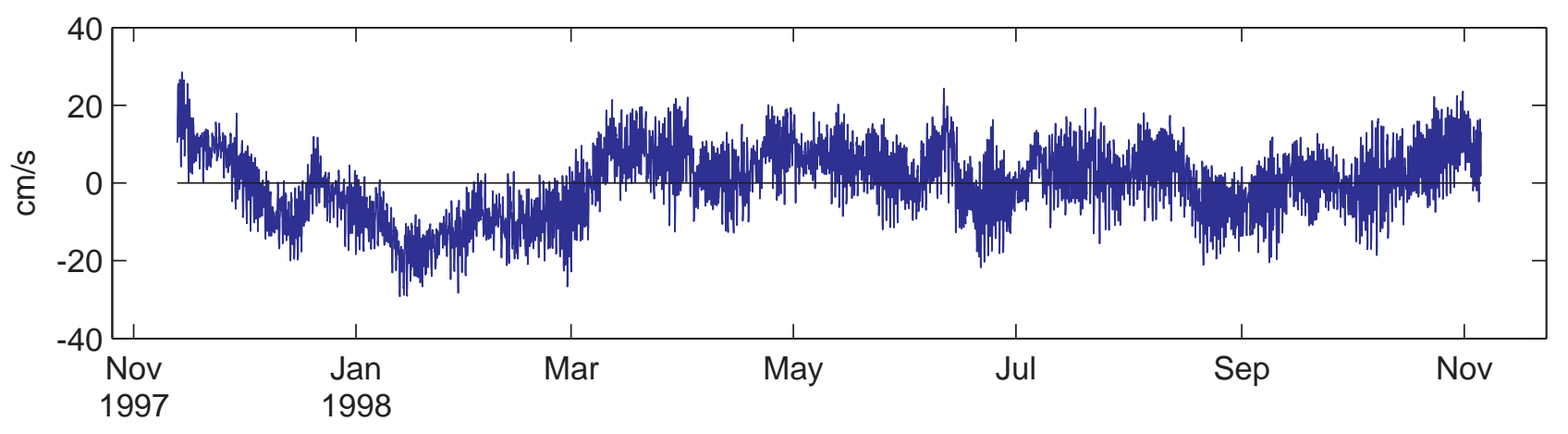

Figure A-3. Hour-averaged along-slope currents (cm/s) at Mooring R1. 
R1,1337 m
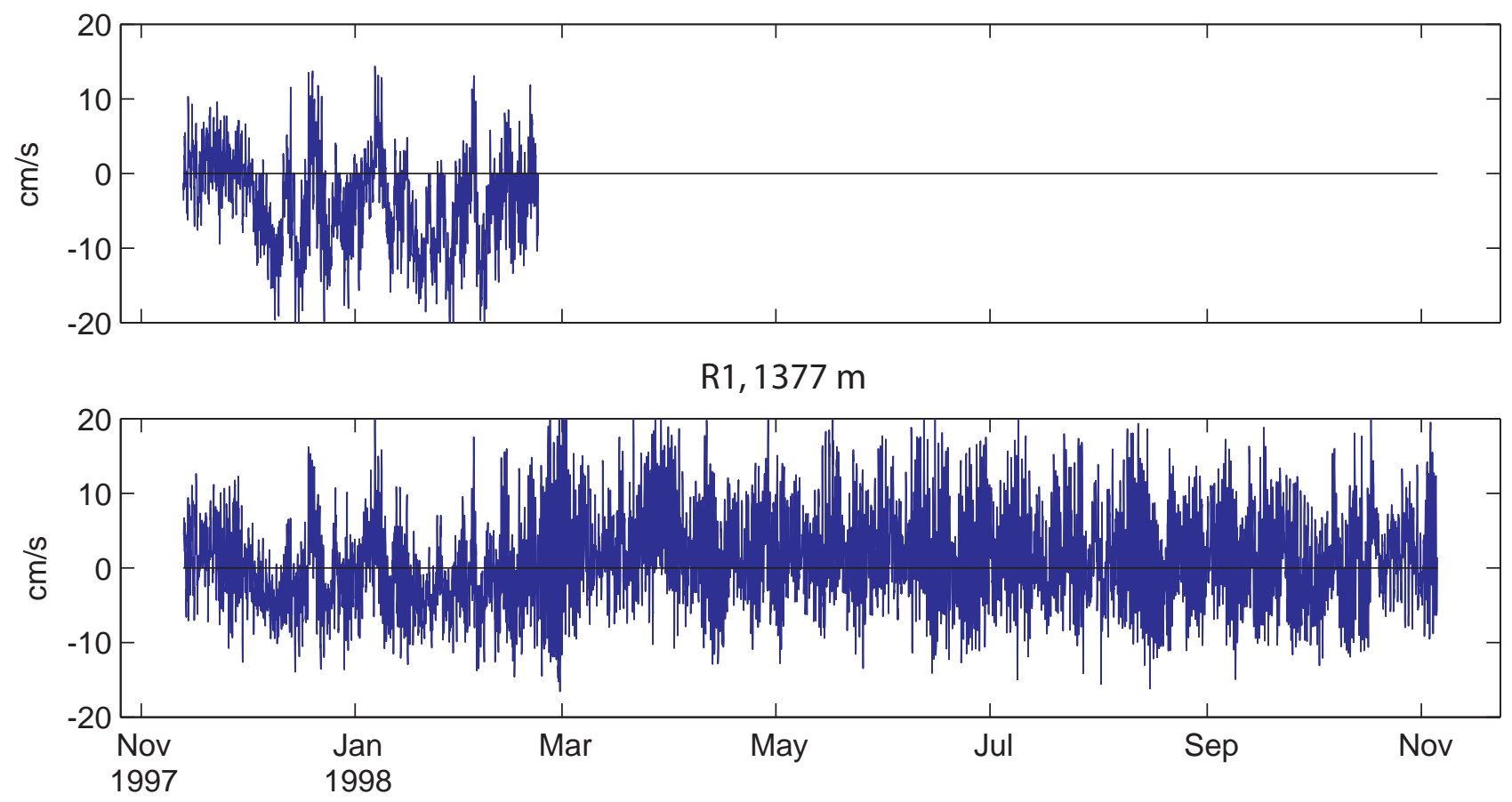

Figure A-3, cont. Hour-averaged along-slope currents (cm/s) at Mooring R1. 
D1, $14 \mathrm{~m}$

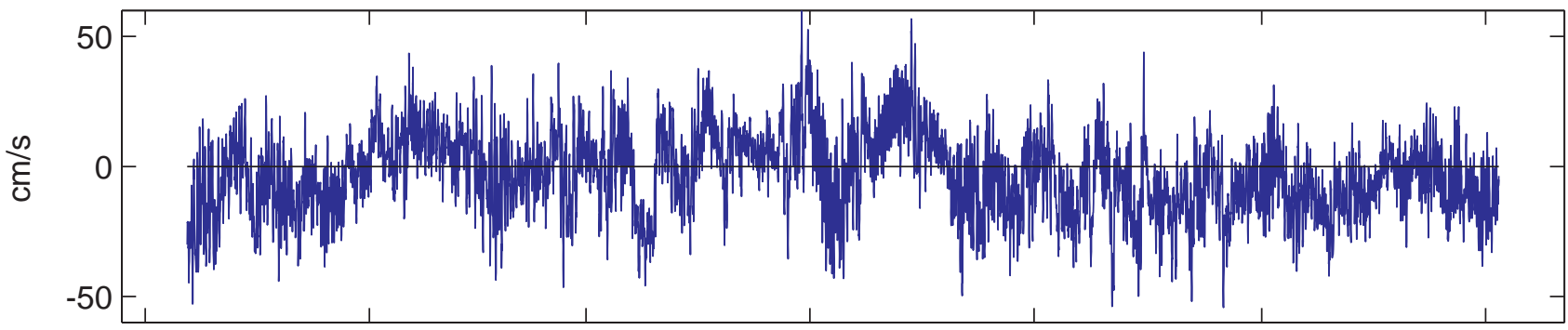

D1, $30 \mathrm{~m}$
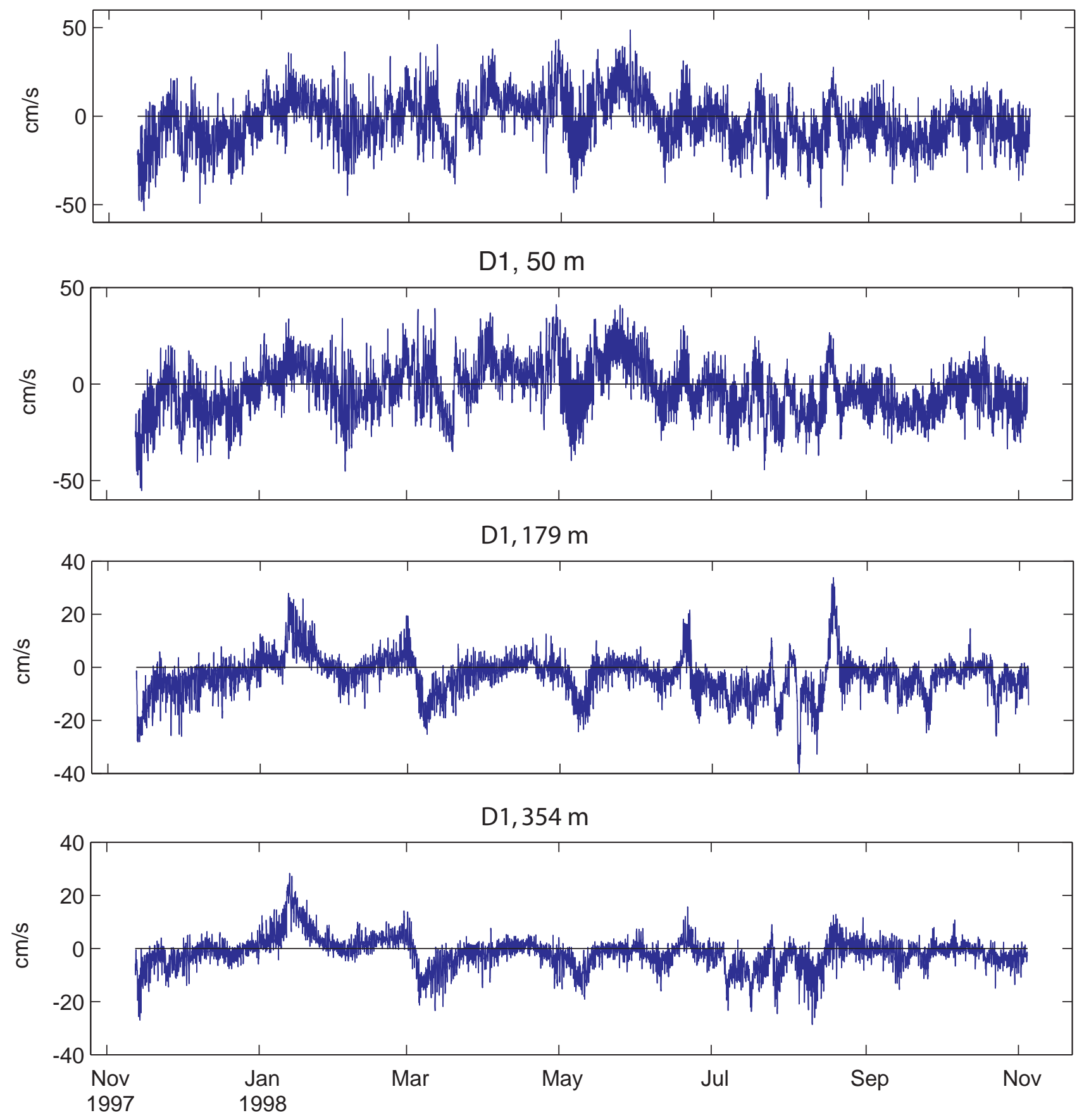

Figure A-4. Hour-averaged cross-slope currents (cm/s) at Mooring D1. 

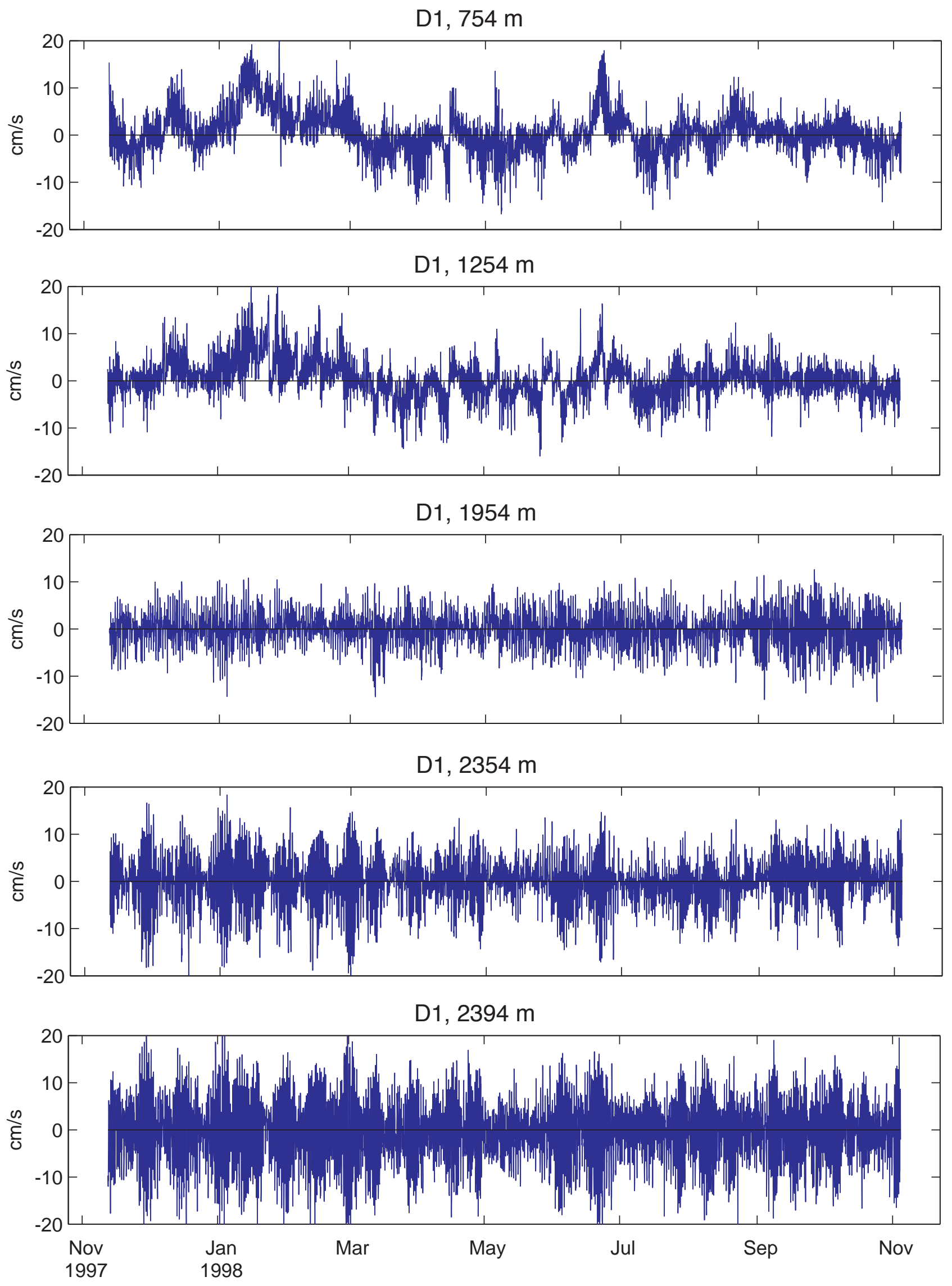

Figure A-4, cont. Hour-averaged cross-slope currents (cm/s) at Mooring D1. 
D2, $90 \mathrm{~m}$

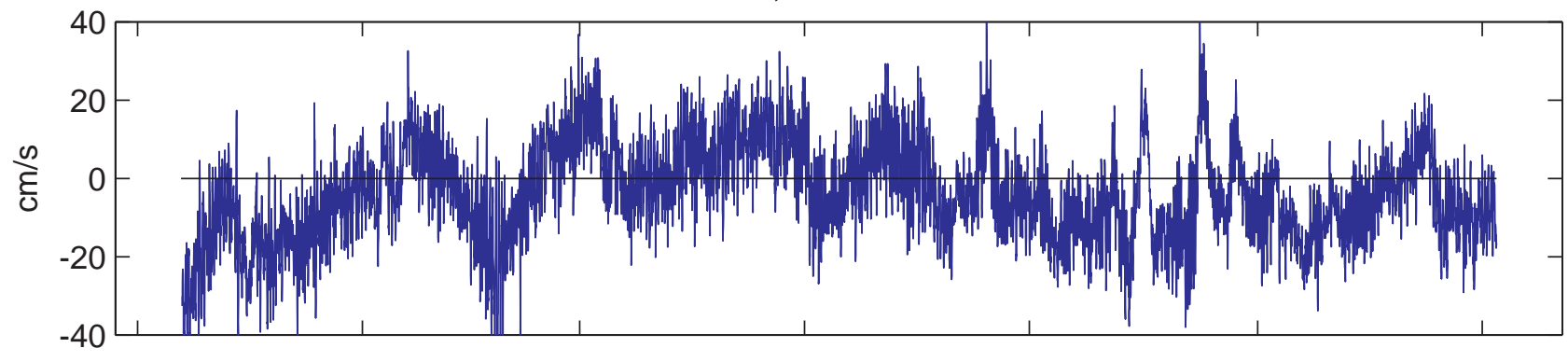

D2, $215 \mathrm{~m}$

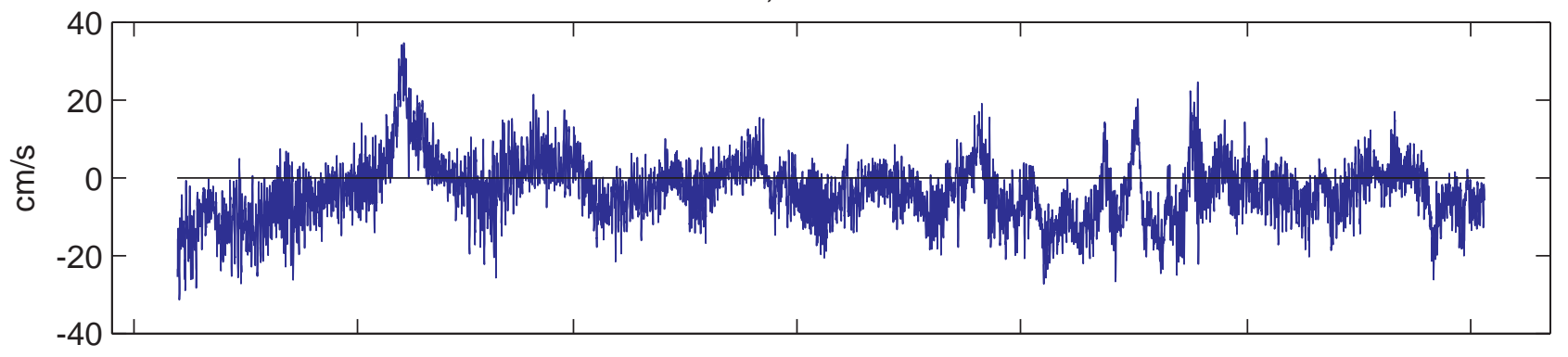

$\mathrm{D} 2,390 \mathrm{~m}$

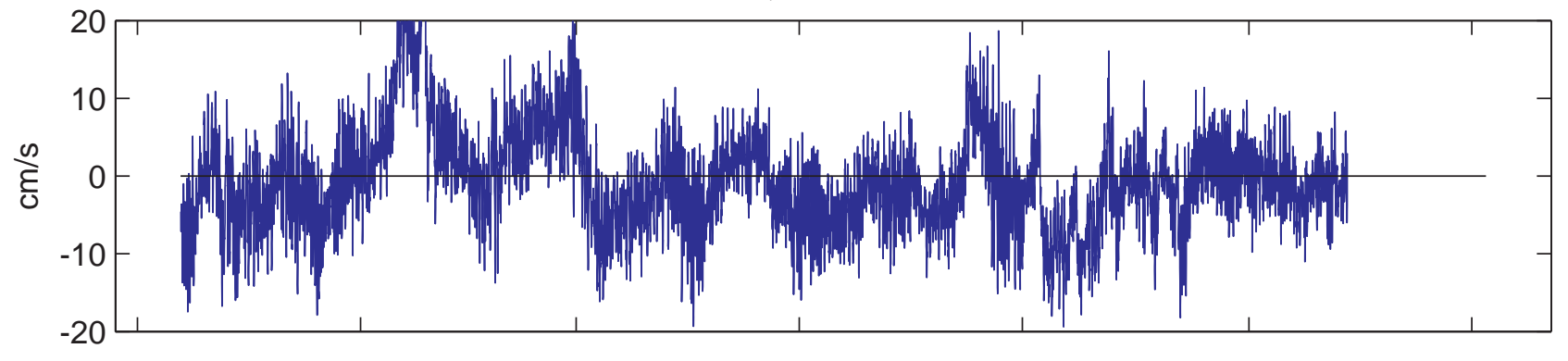

D2, $790 \mathrm{~m}$

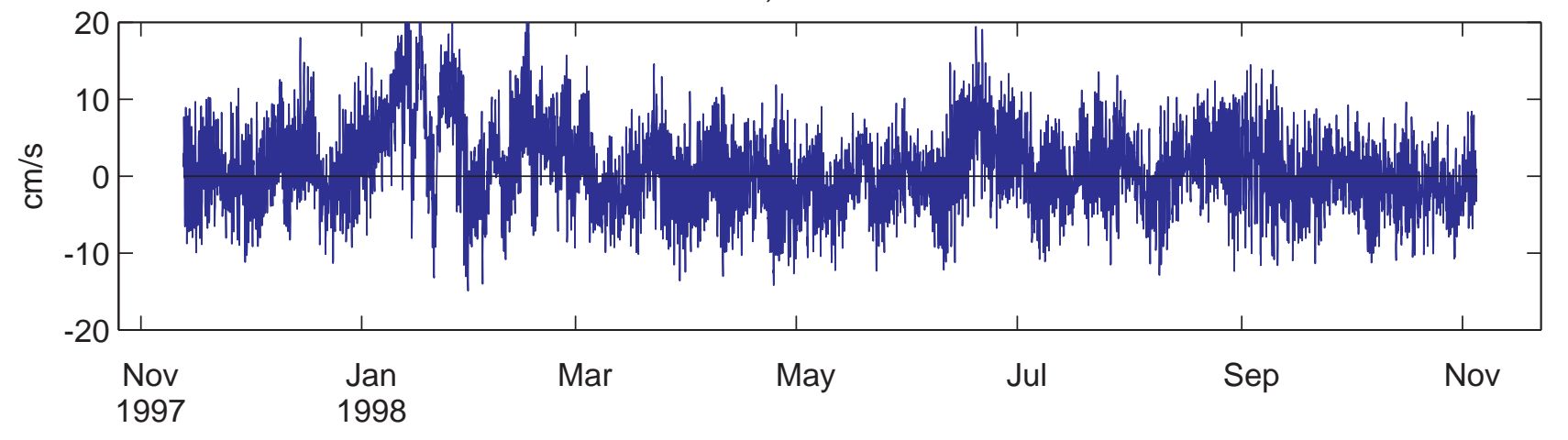

Figure A-5. Hour-averaged cross-slope currents (cm/s) at Mooring D2. 

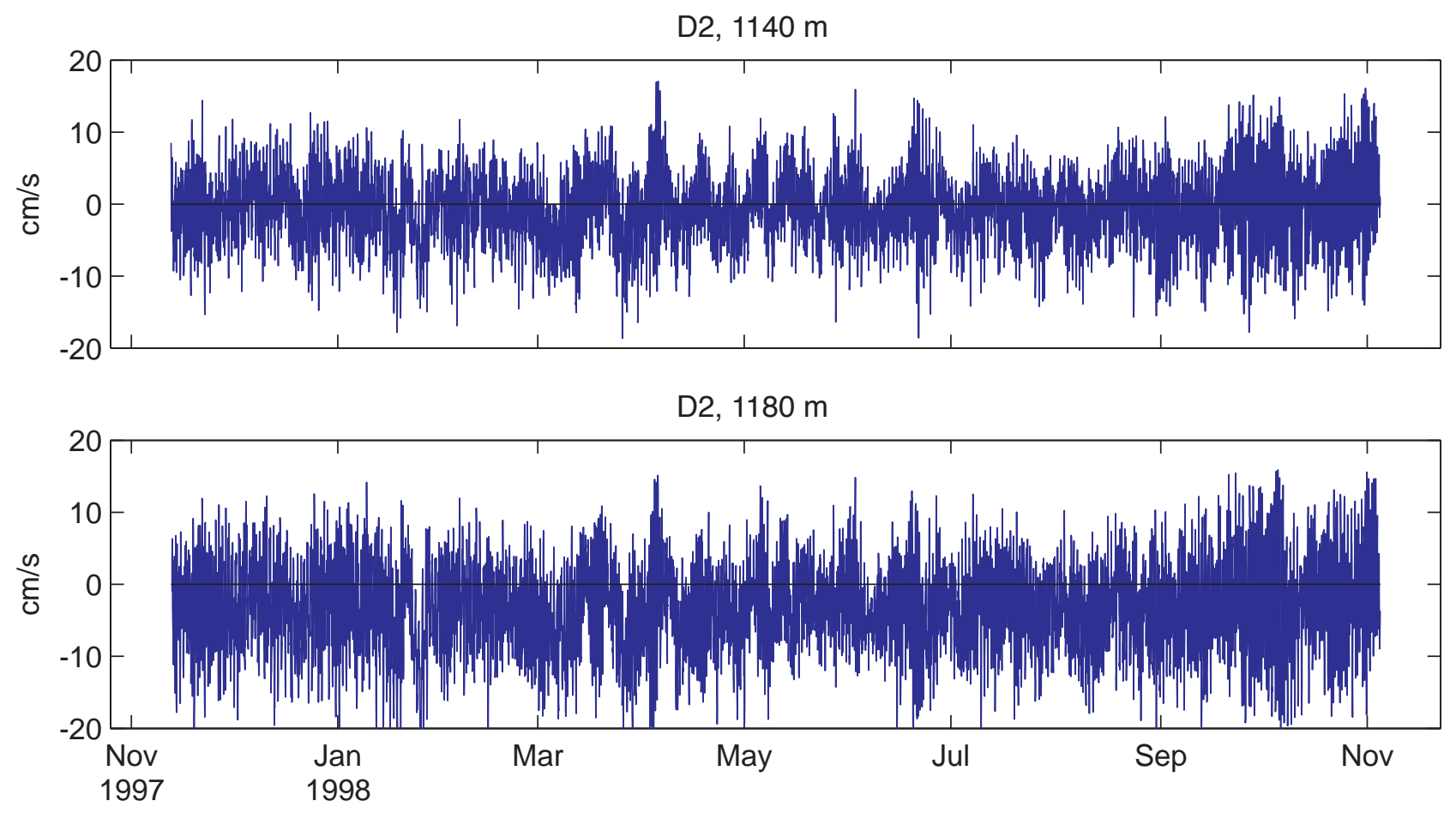

Figure A-5, cont. Hour-averaged cross-slope currents $(\mathrm{cm} / \mathrm{s})$ at Mooring D2. 
$\mathrm{R} 1,90 \mathrm{~m}$

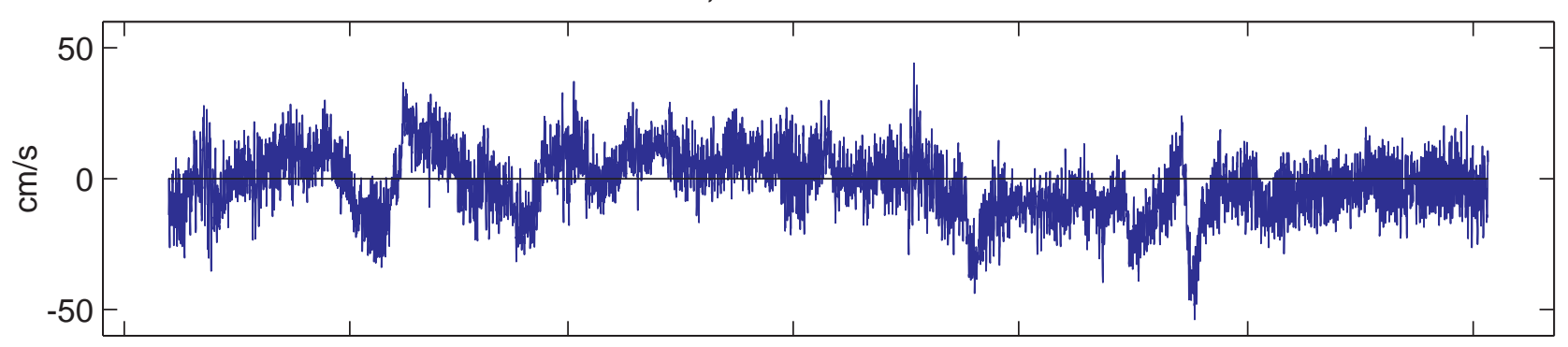

\section{$\mathrm{R} 1,212 \mathrm{~m}$}

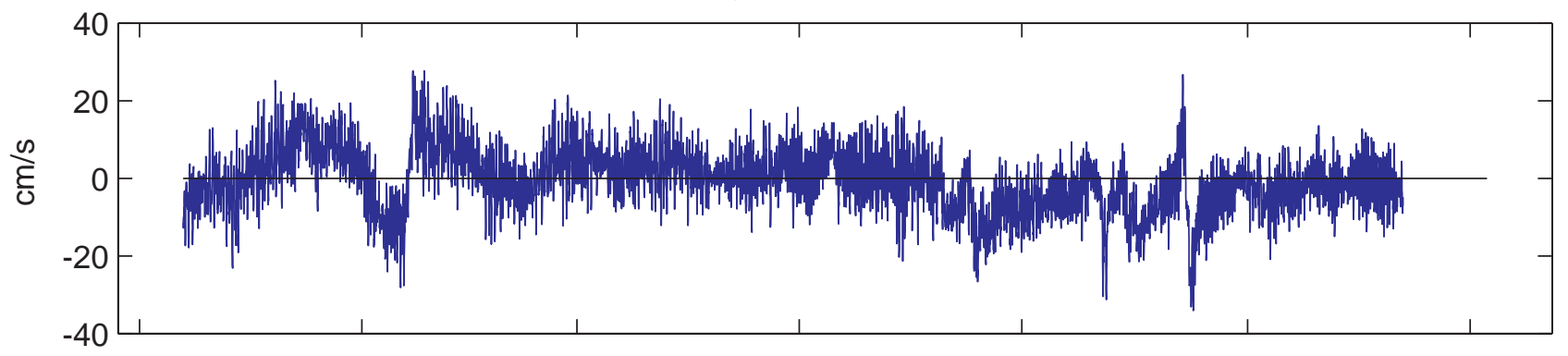

$\mathrm{R} 1,387 \mathrm{~m}$

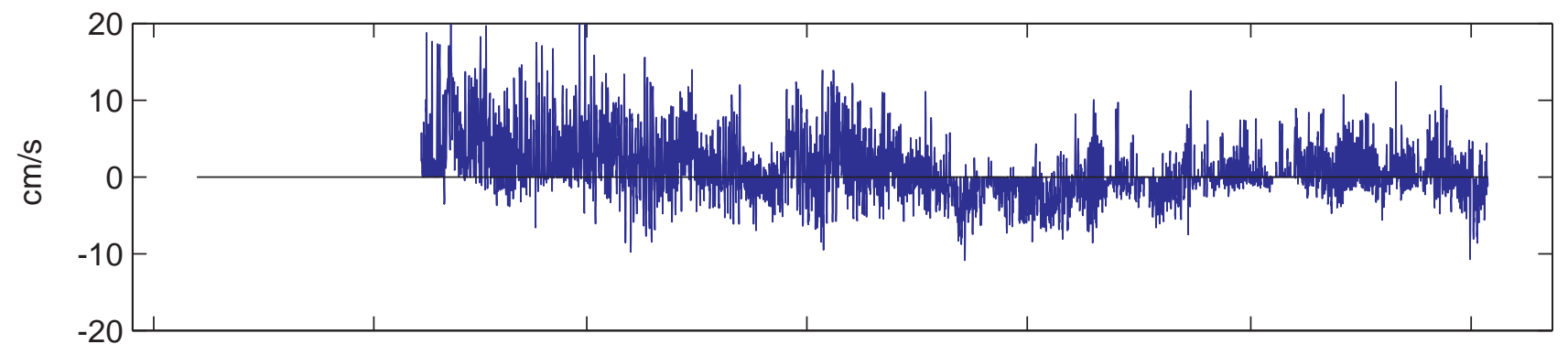

$\mathrm{R} 1,787 \mathrm{~m}$

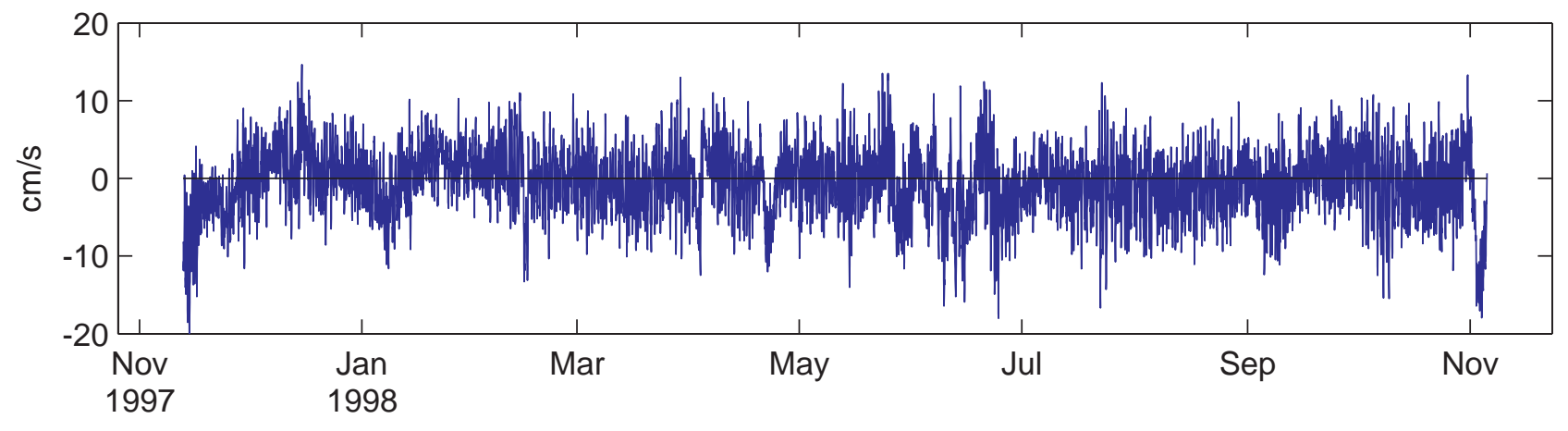

Figure A-6. Hour-averaged cross-slope currents $(\mathrm{cm} / \mathrm{s})$ at Mooring R1. 

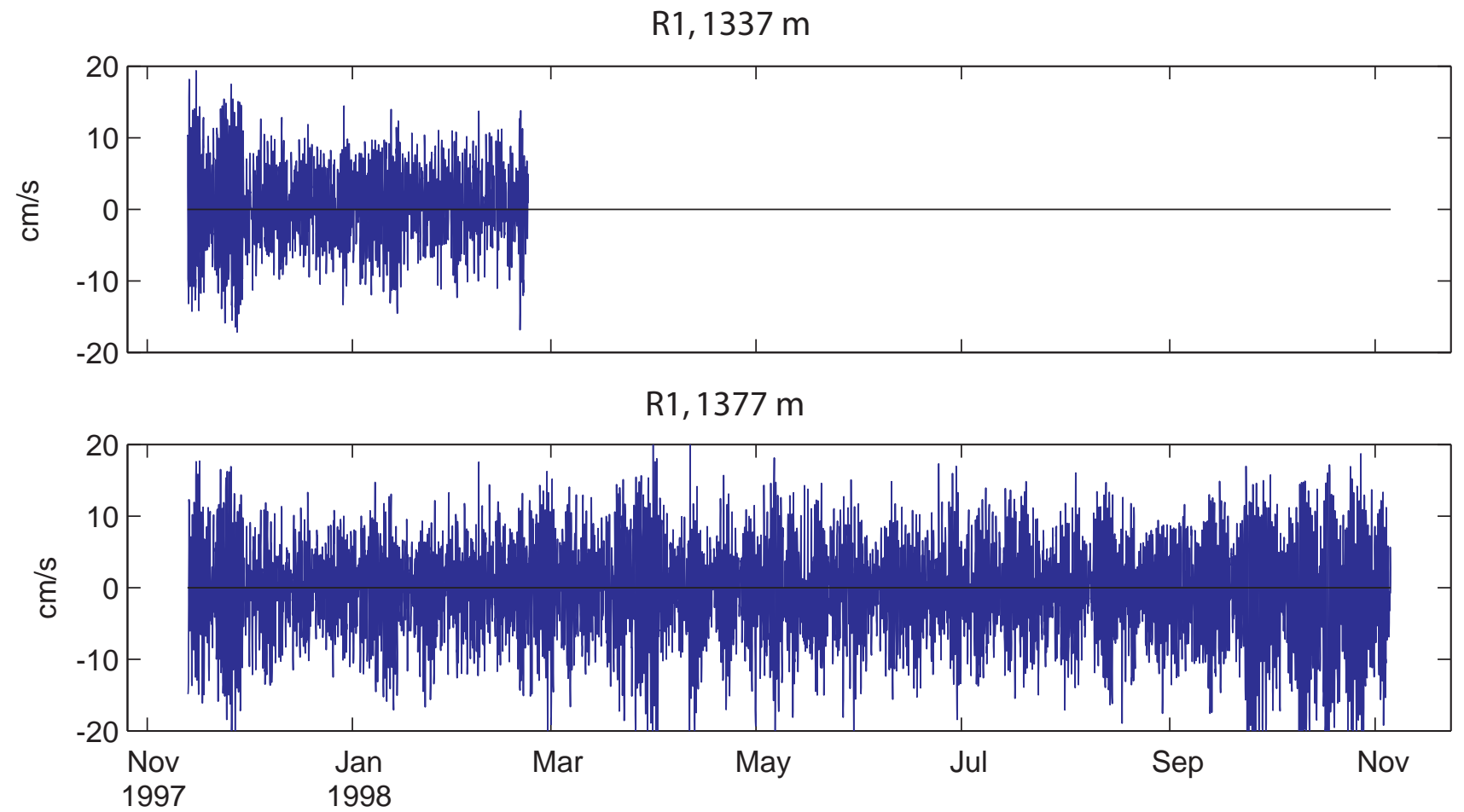

Figure A-6, cont. Hour-averaged cross-slope currents (cm/s) at Mooring R1. 
Appendix B.

Hour-averaged low-pass-filtered currents 


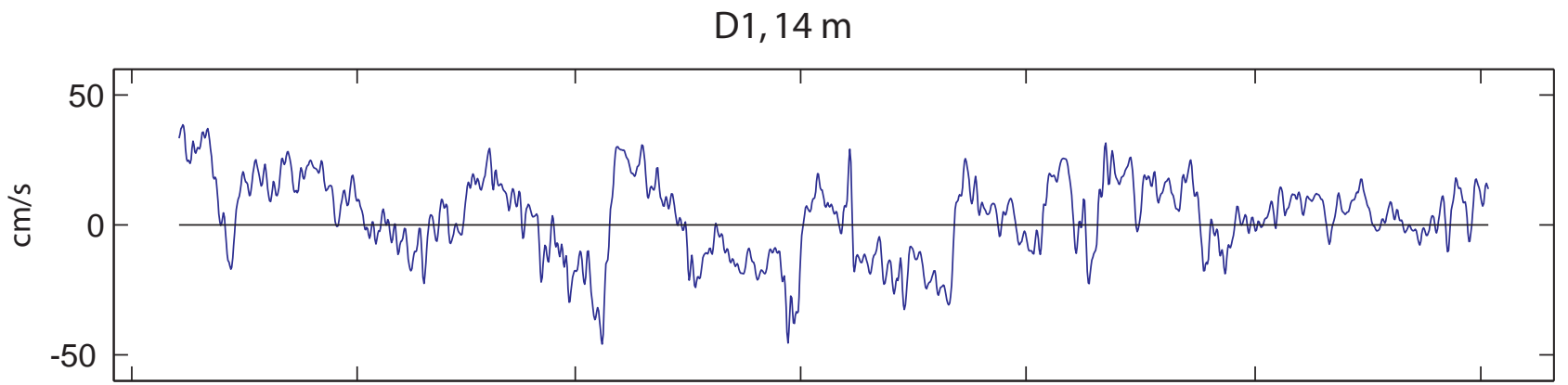

D1, $30 \mathrm{~m}$

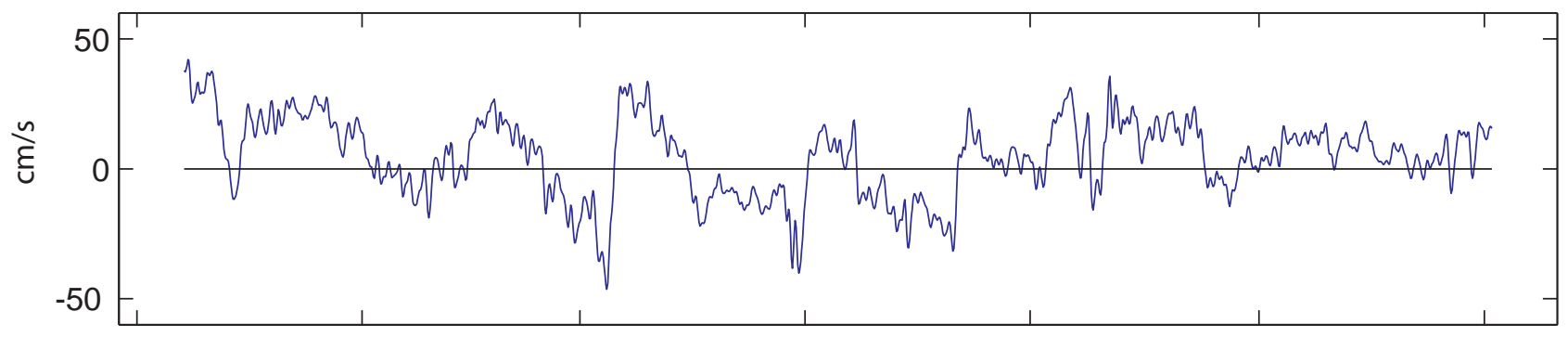

$\mathrm{D} 1,50 \mathrm{~m}$
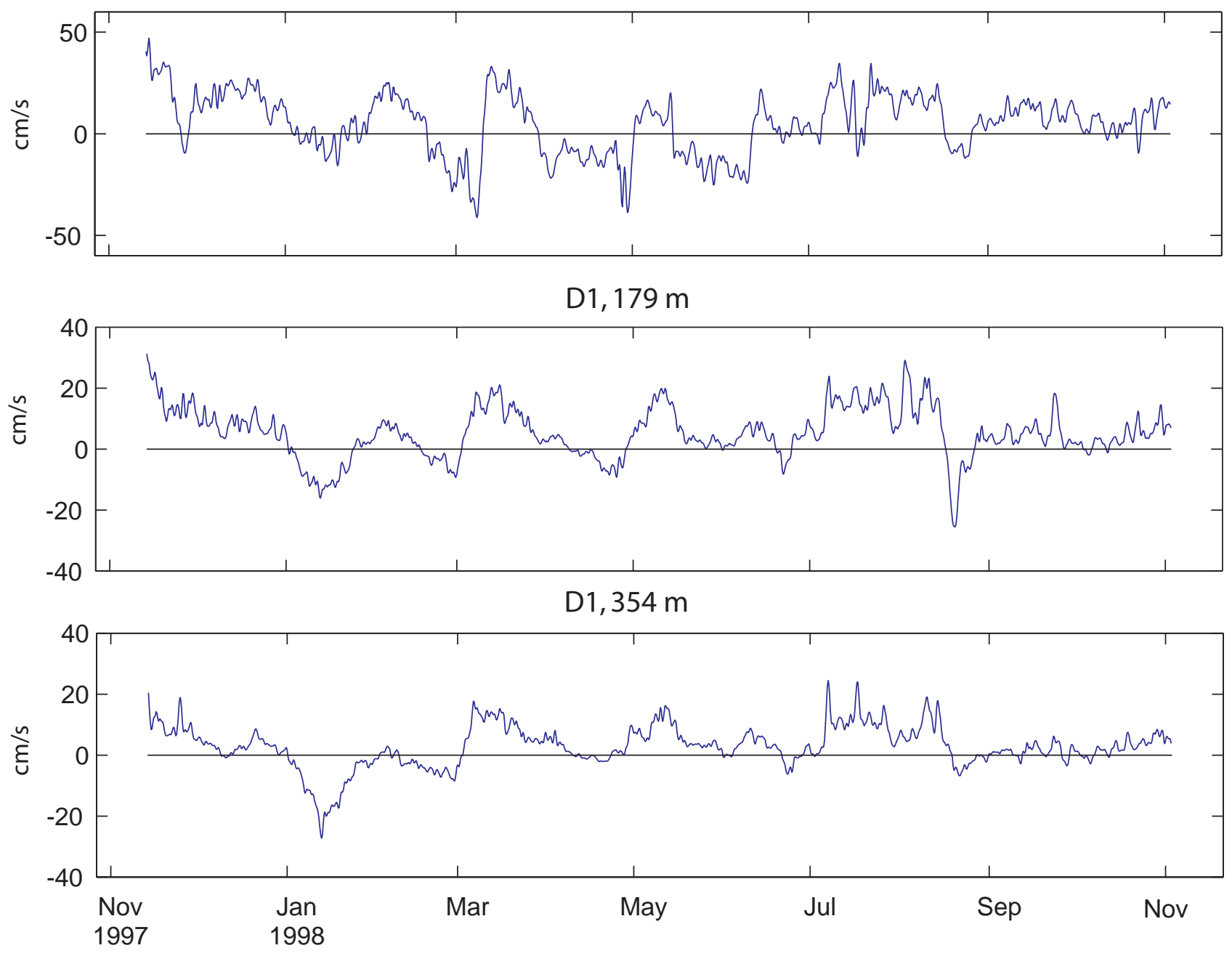

Figure B-1. Hour-averaged low-pass filtered along-slope currents (cm/s) at Mooring D1. 

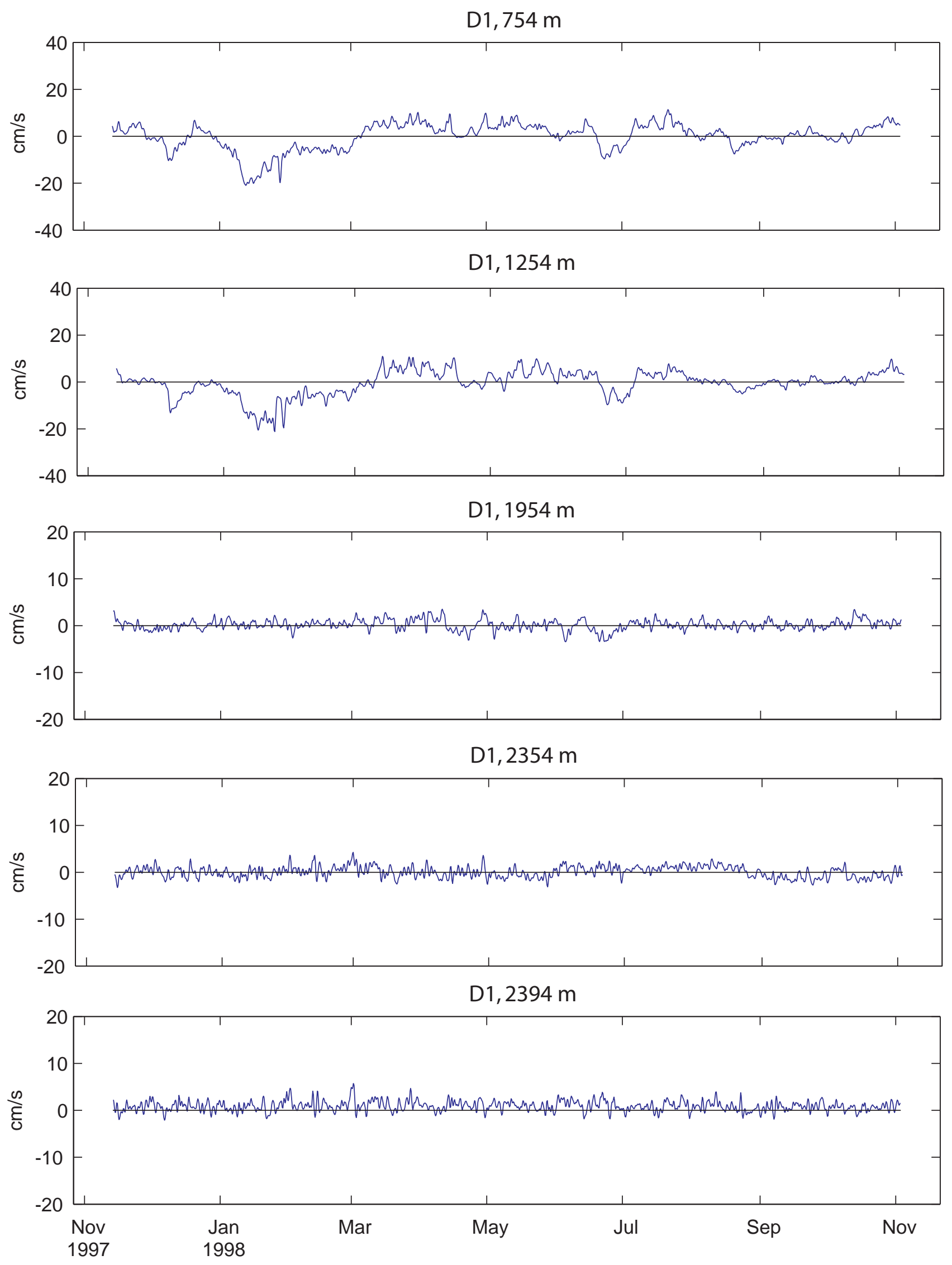

Figure B-1, cont. Hour-averaged low-pass filtered along-slope currents (cm/s) at Mooring D1. 


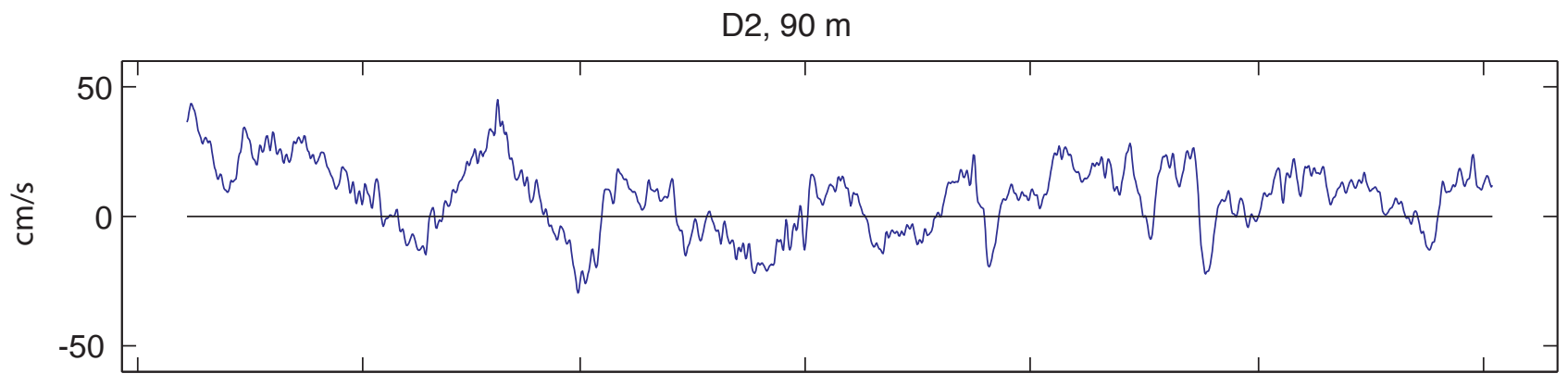

D2, $215 \mathrm{~m}$
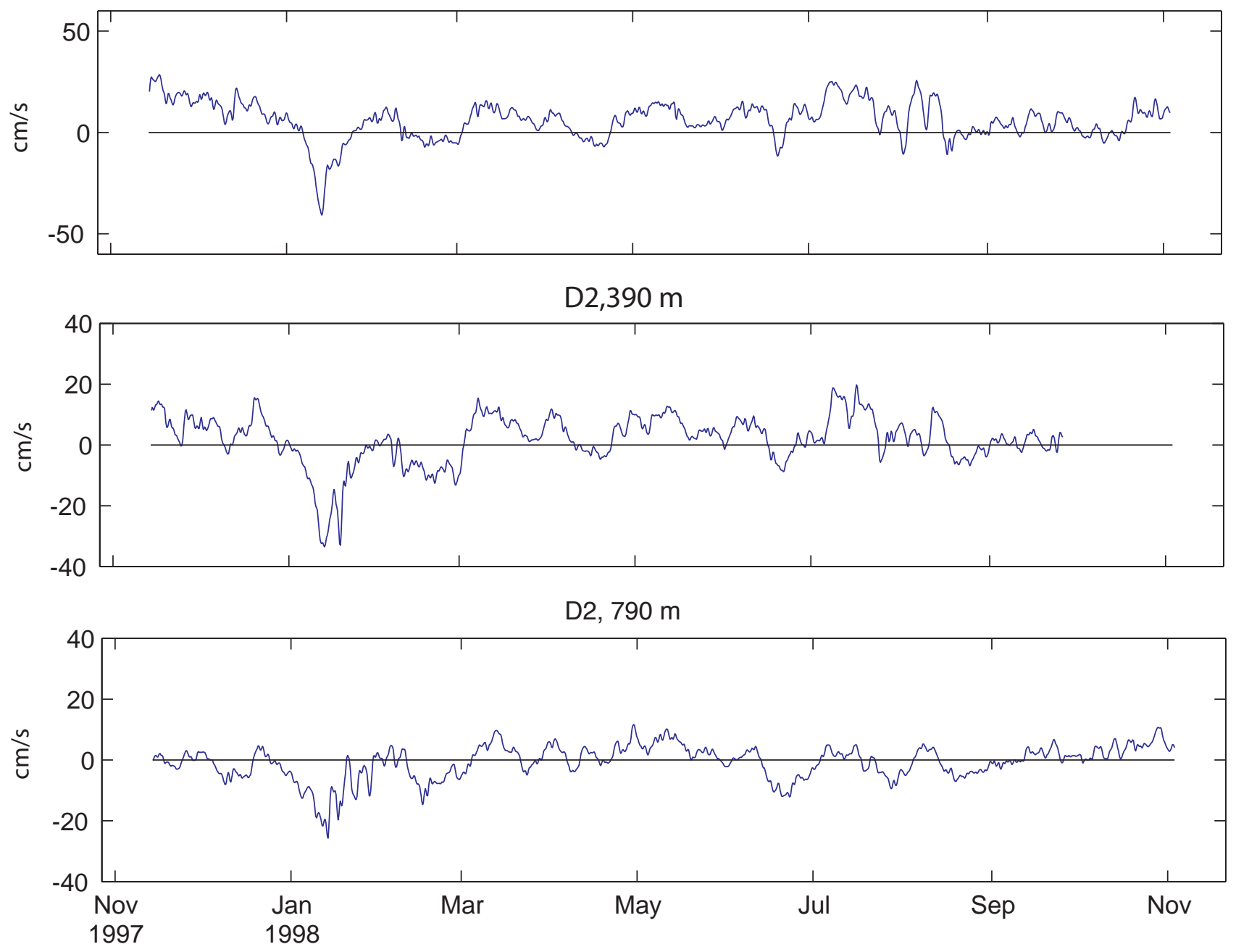

Figure B-2. Hour-averaged low-pass filtered along-slope currents (cm/s) at Mooring D2. 

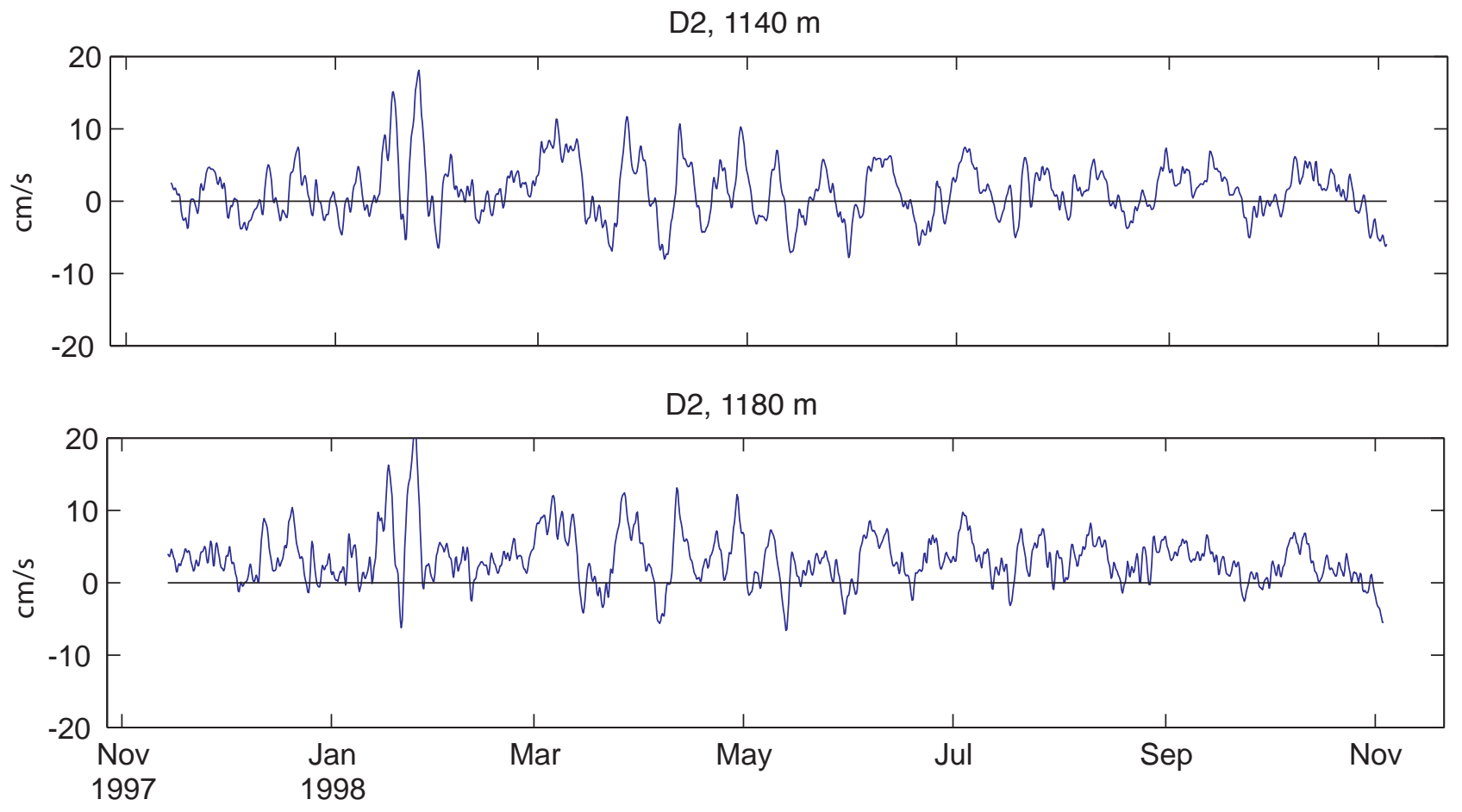

Figure B-2, cont. Hour-averaged low-pass filtered along-slope currents (cm/s) at Mooring D2. 
$\mathrm{R} 1,81 \mathrm{~m}$

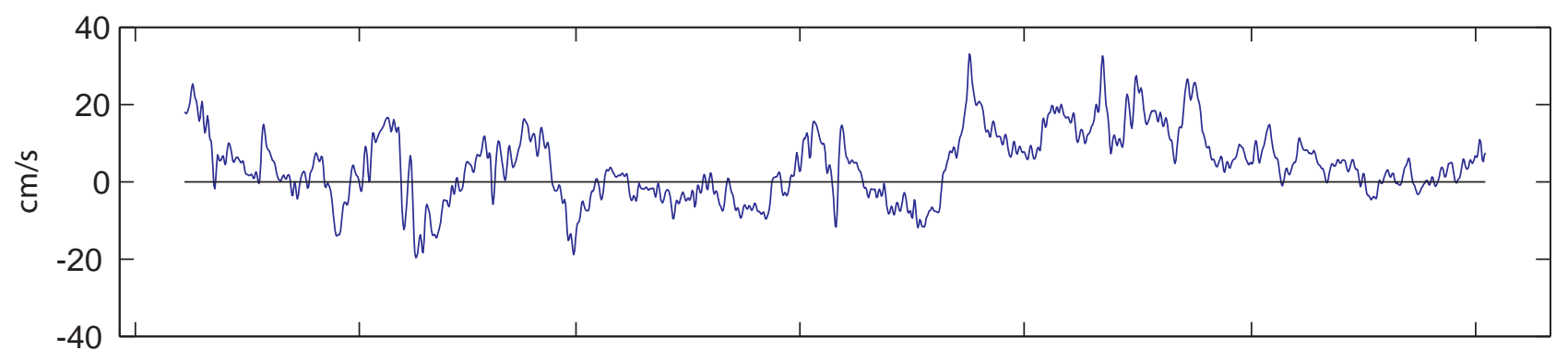

R1, 212

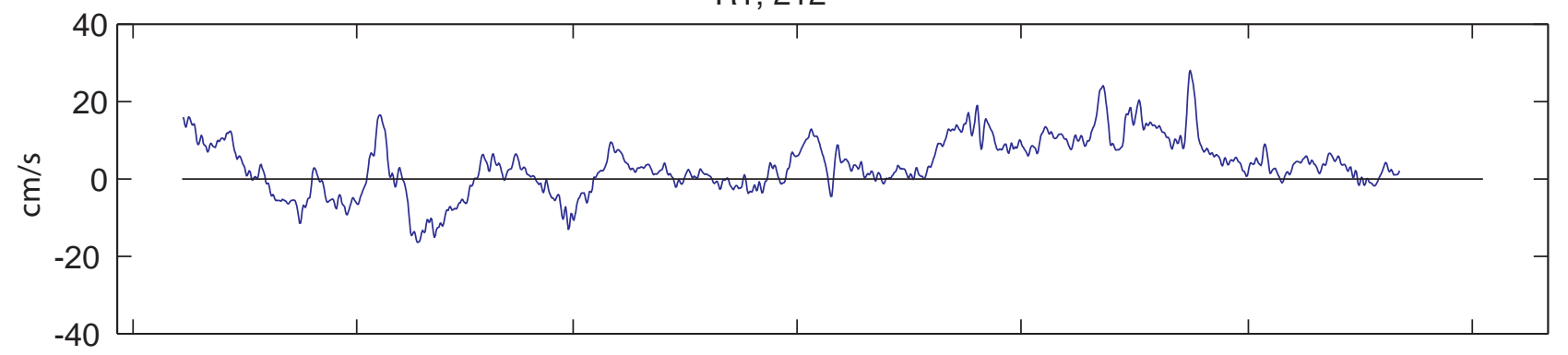

R1, $387 \mathrm{~m}$

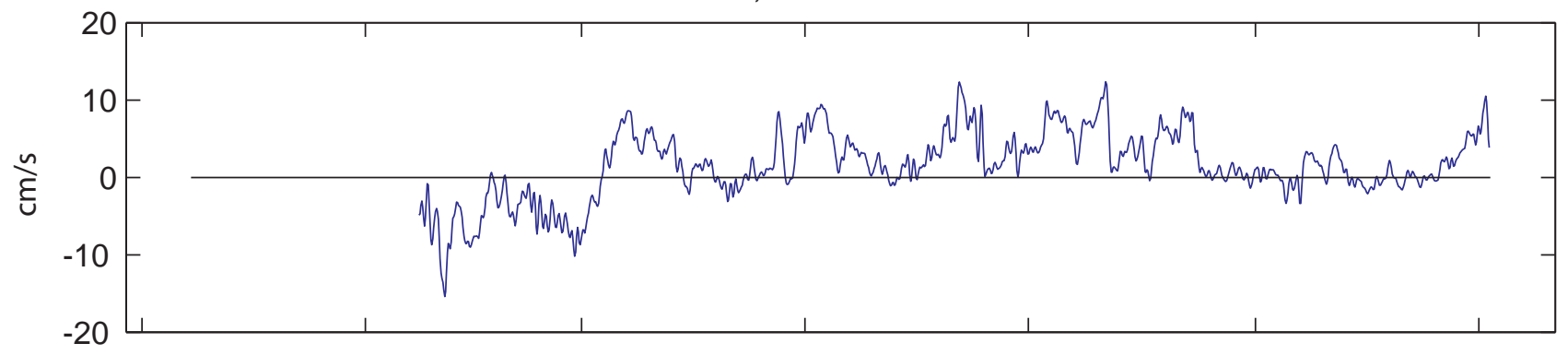

R1, 787 m

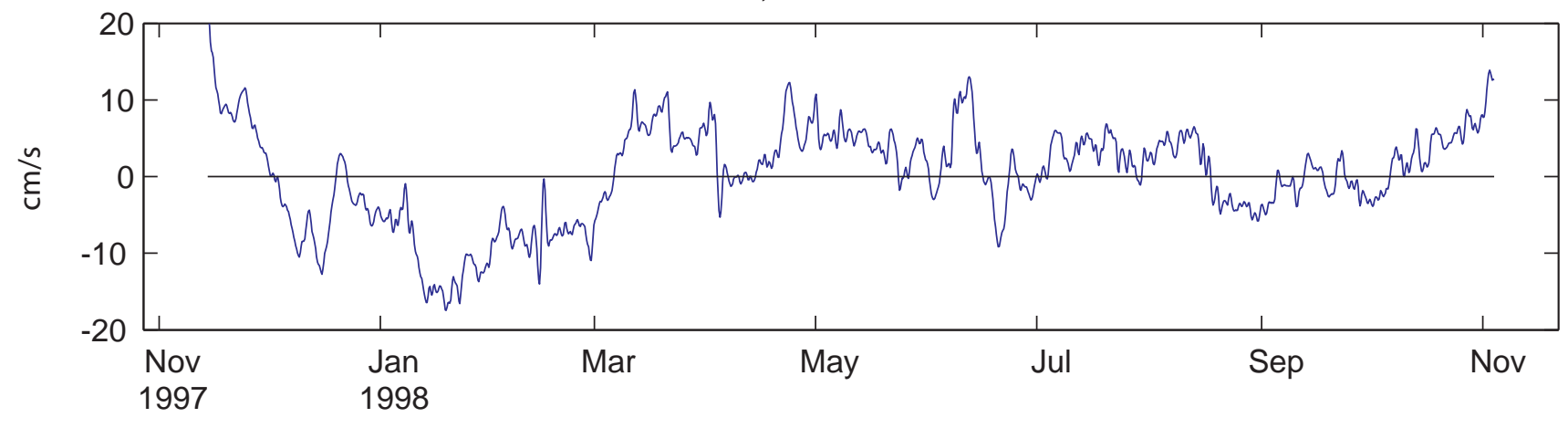

Figure B-3. Hour-averaged low-pass filtered along-slope currents (cm/s) at Mooring R1. 

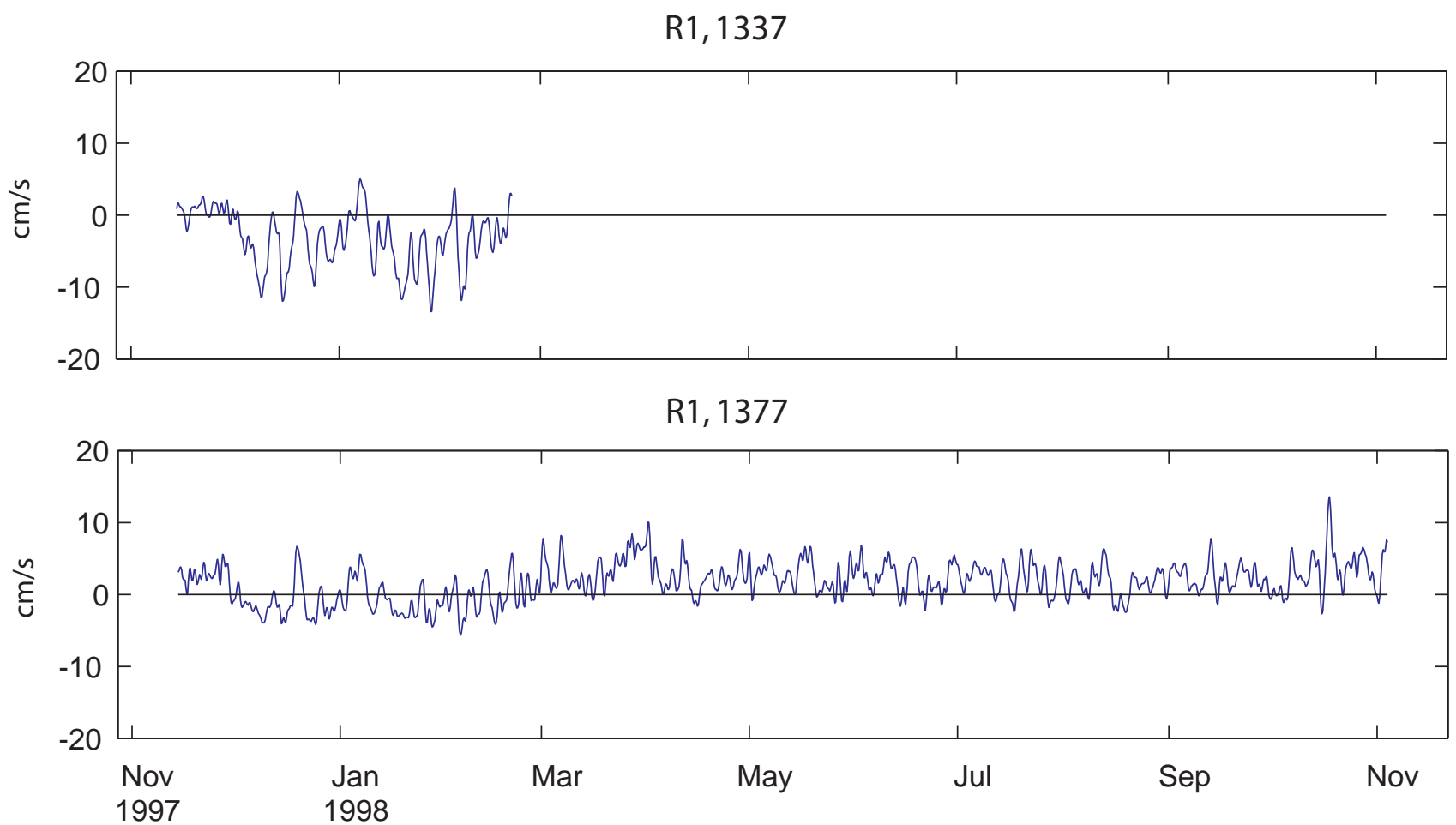

Figure B-3, cont. Hour-averaged low-pass filtered along-slope currents (cm/s) at Mooring R1. 

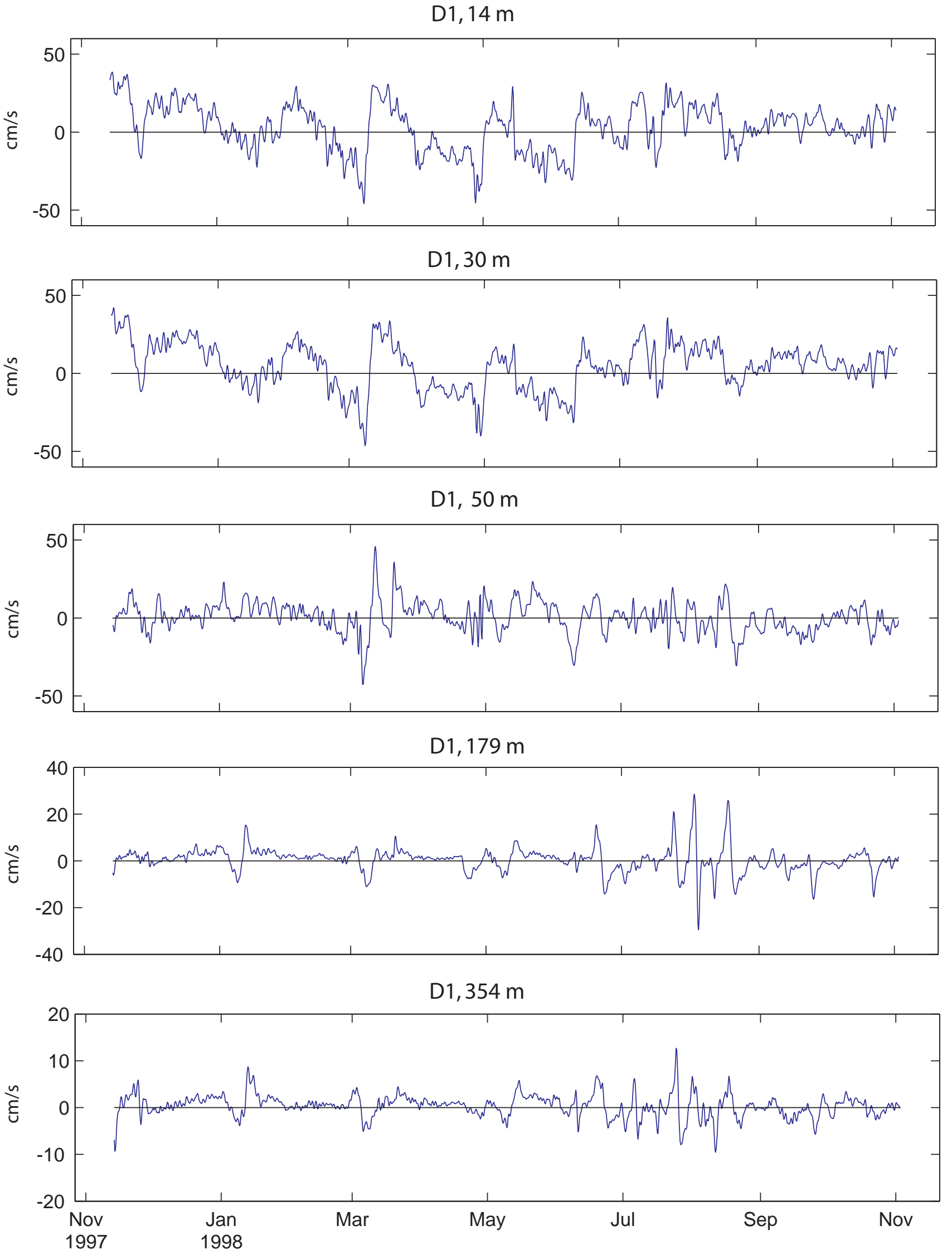

Figure B-4. Hour-averaged low-pass filtered cross-slope currents (cm/s) at Mooring D1. 

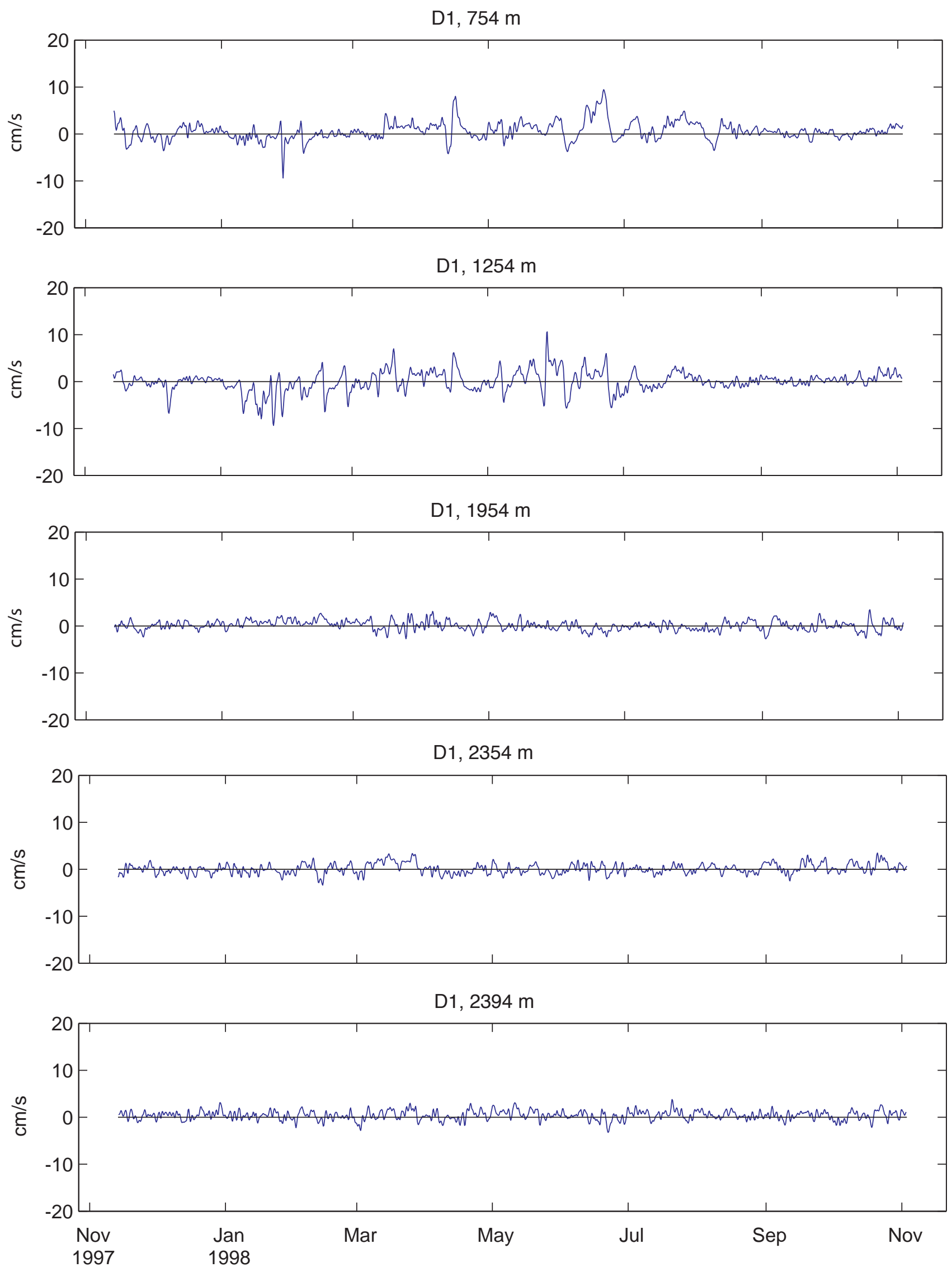

Figure B-4, cont. Hour-averaged low-pass filtered cross-slope currents $(\mathrm{cm} / \mathrm{s})$ at Mooring D1. 


\section{$\mathrm{D} 2,90 \mathrm{~m}$}

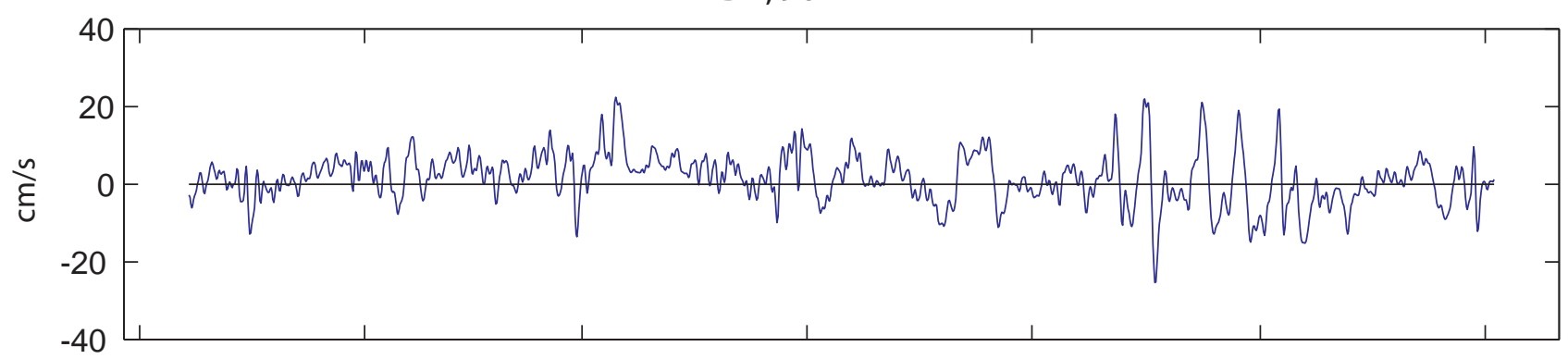

$\mathrm{D} 2,215 \mathrm{~m}$
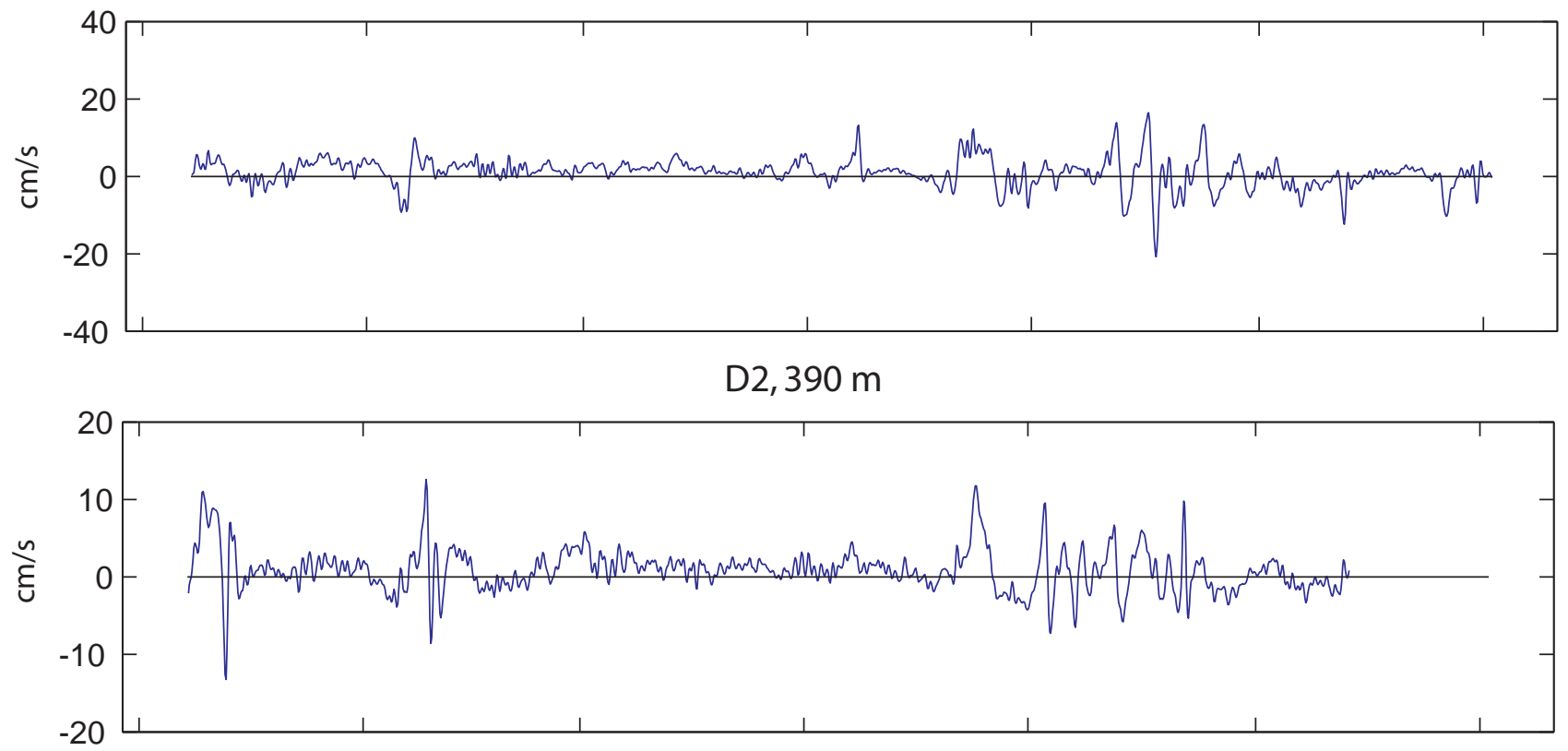

$\mathrm{D} 2,790 \mathrm{~m}$

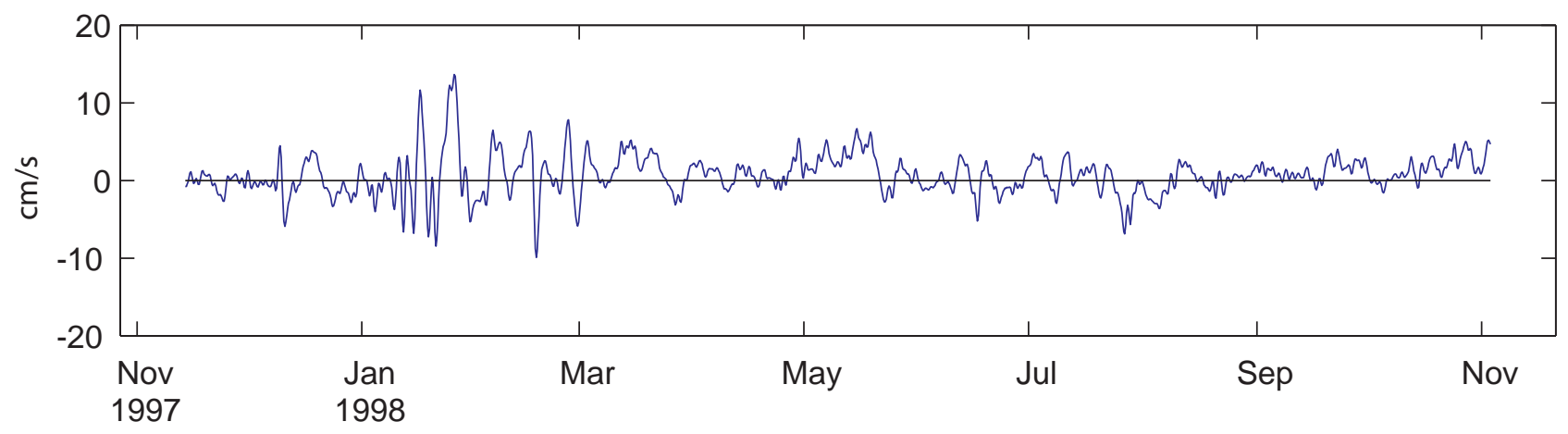

Figure B-5. Hour-averaged low-pass filtered cross-slope currents $(\mathrm{cm} / \mathrm{s})$ at Mooring D2. 
$\mathrm{D} 2,1140 \mathrm{~m}$
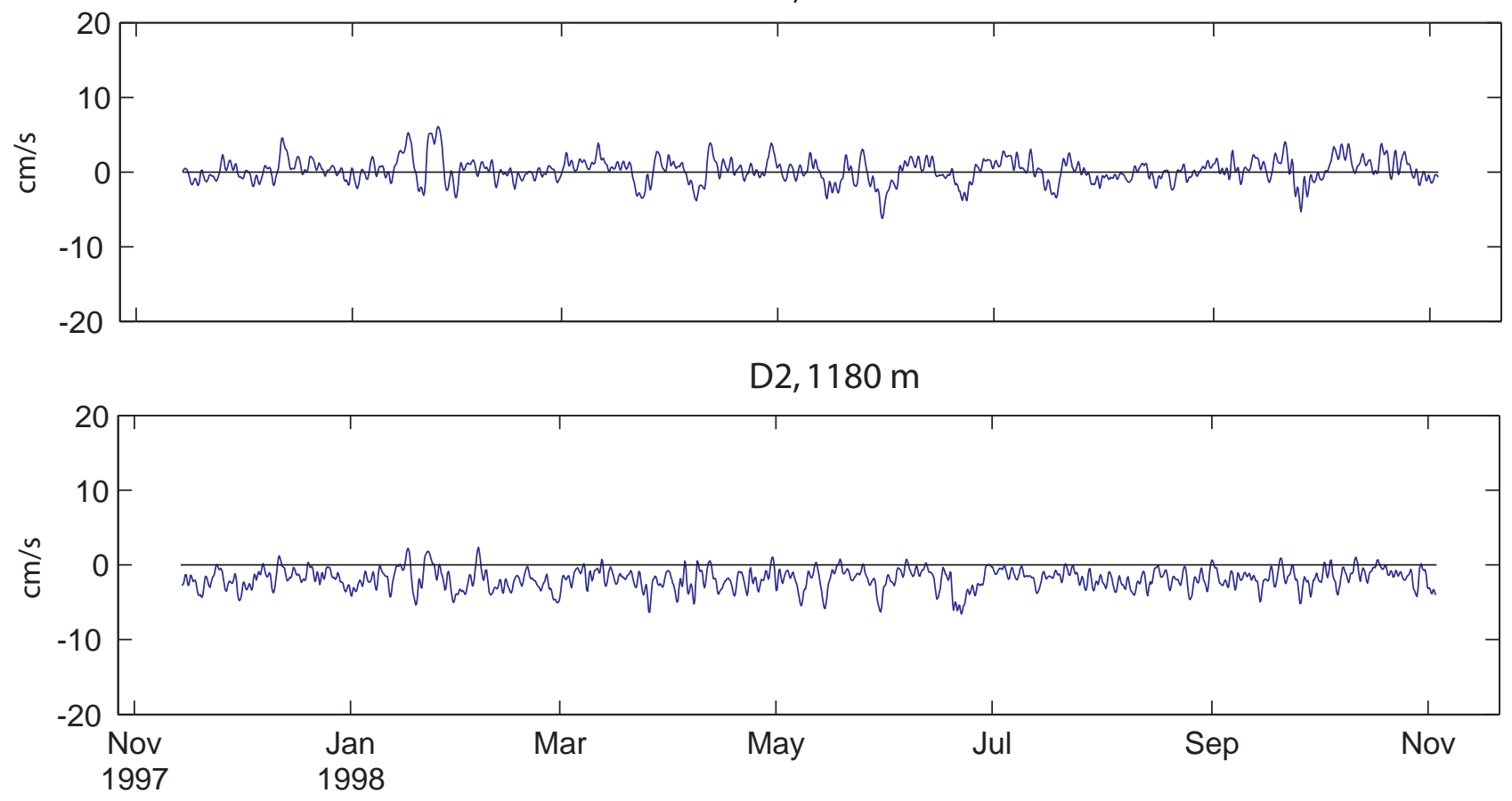

Figure B-5, cont. Hour-averaged low-pass filtered cross-slope currents(cm/s) at Mooring D2. 
$\mathrm{R} 1,81 \mathrm{~m}$

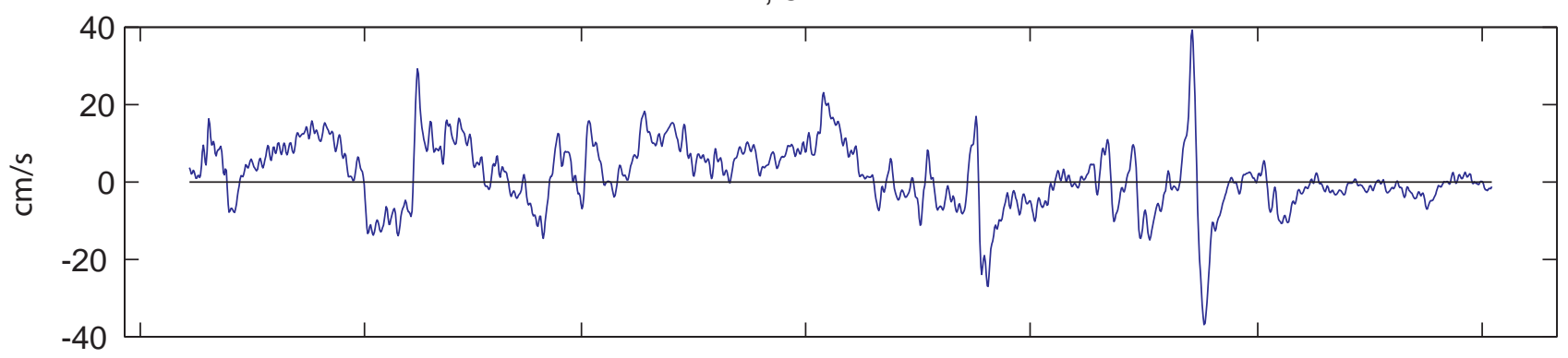

$\mathrm{R} 1,212 \mathrm{~m}$

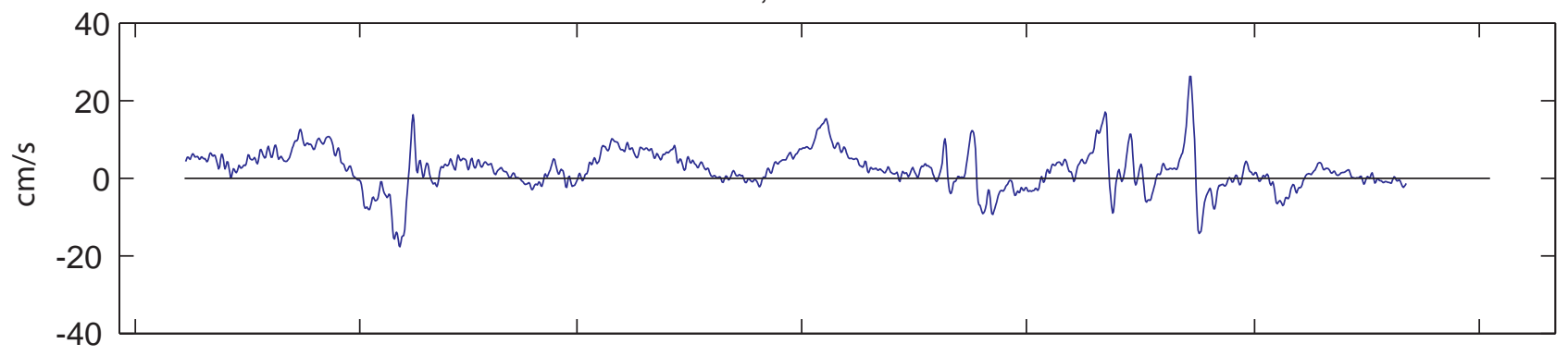

R1, 387 m

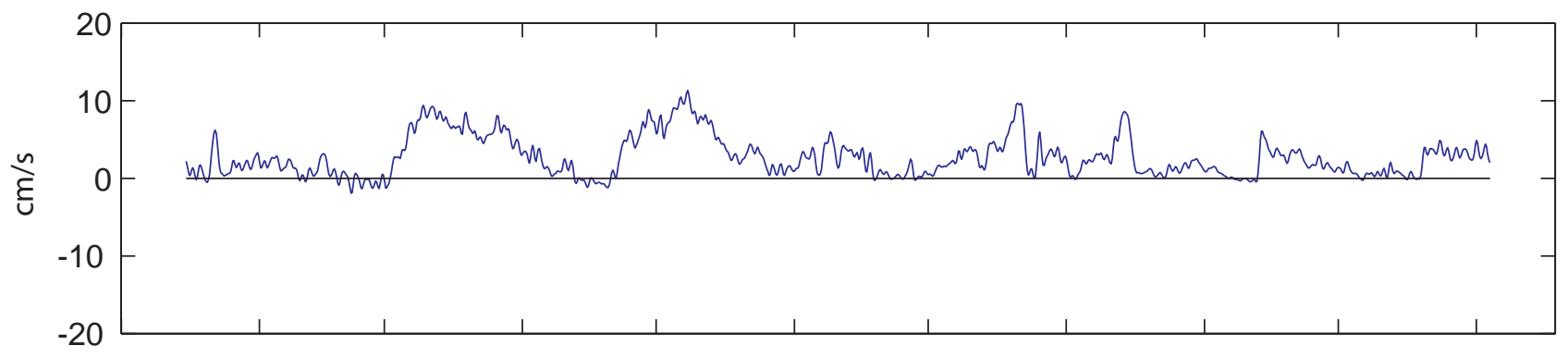

$\mathrm{R} 1,787 \mathrm{~m}$

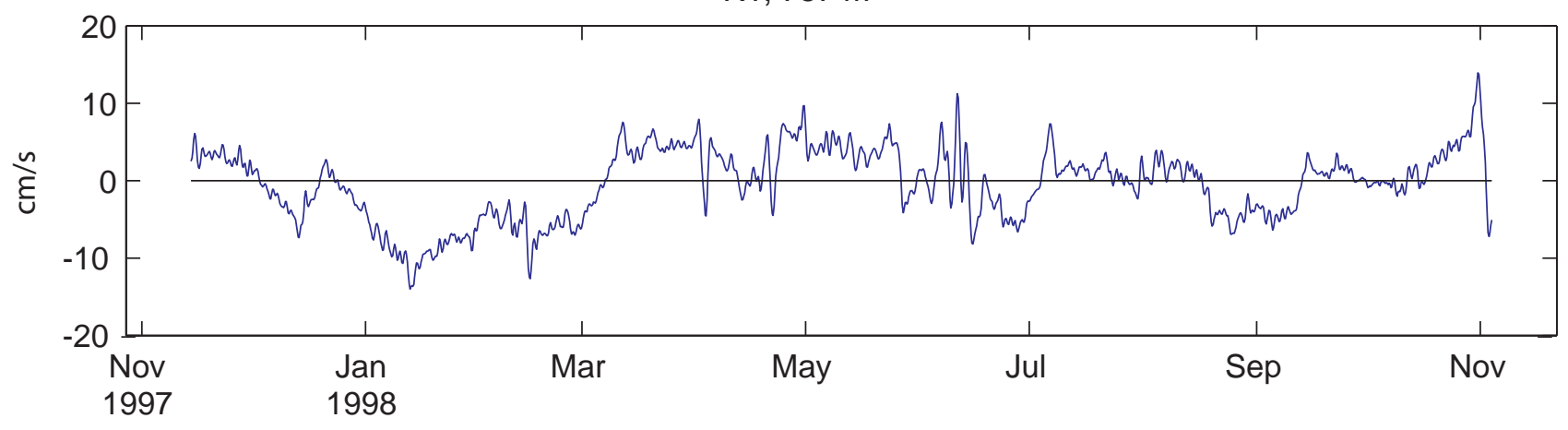

Figure B-6. Hour-averaged low-pass filtered cross-slope currents (cm/s) at Mooring R1. 
R1, 1337 m

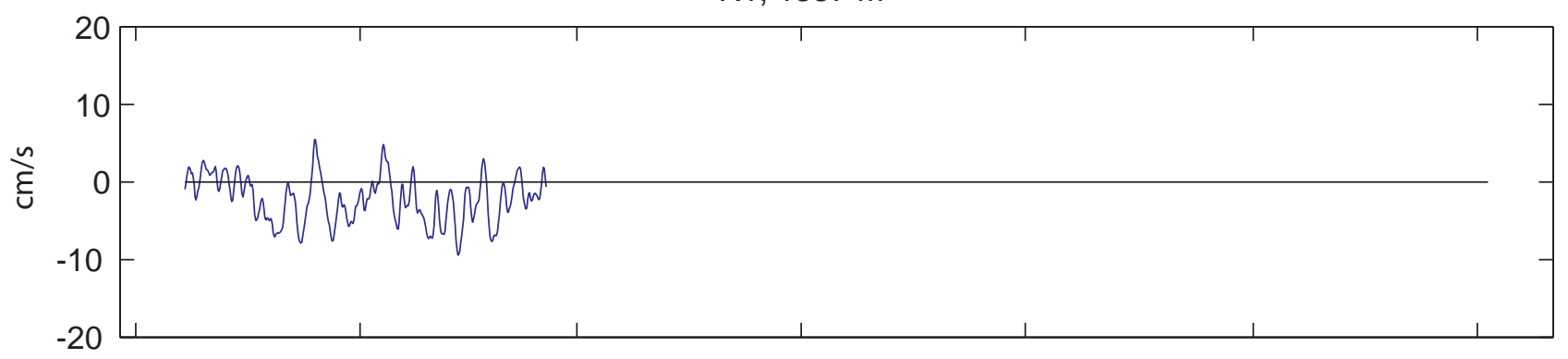

$\mathrm{R} 1,1377 \mathrm{~m}$

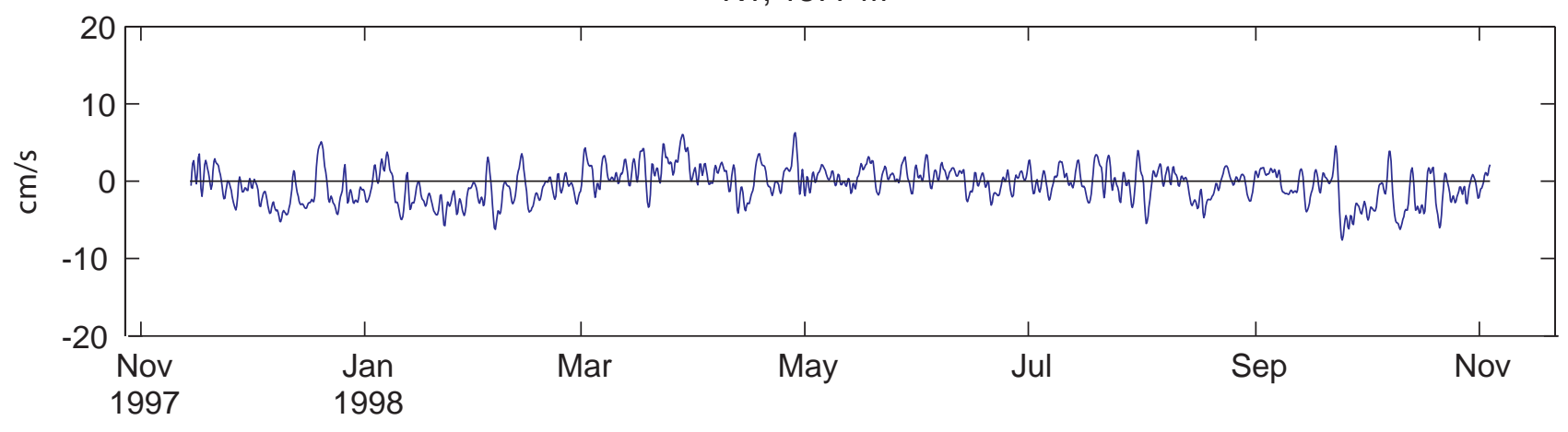

Figure B-6, cont. Hour-averaged low-pass filtered cross-slope currents(cm/s) at Mooring R1. 
Appendix C.

Subtidal current vectors 
D1, $14 \mathrm{~m}$

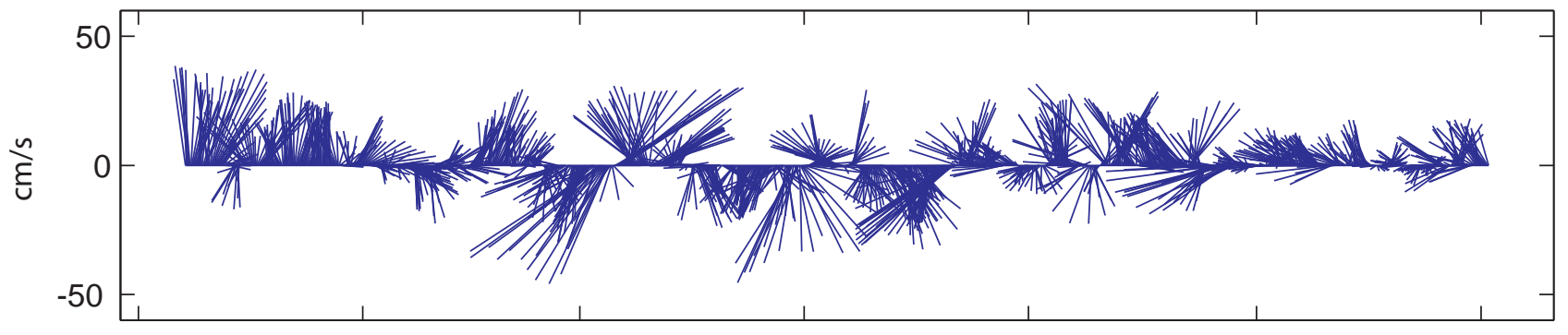

$\mathrm{D} 1,30 \mathrm{~m}$

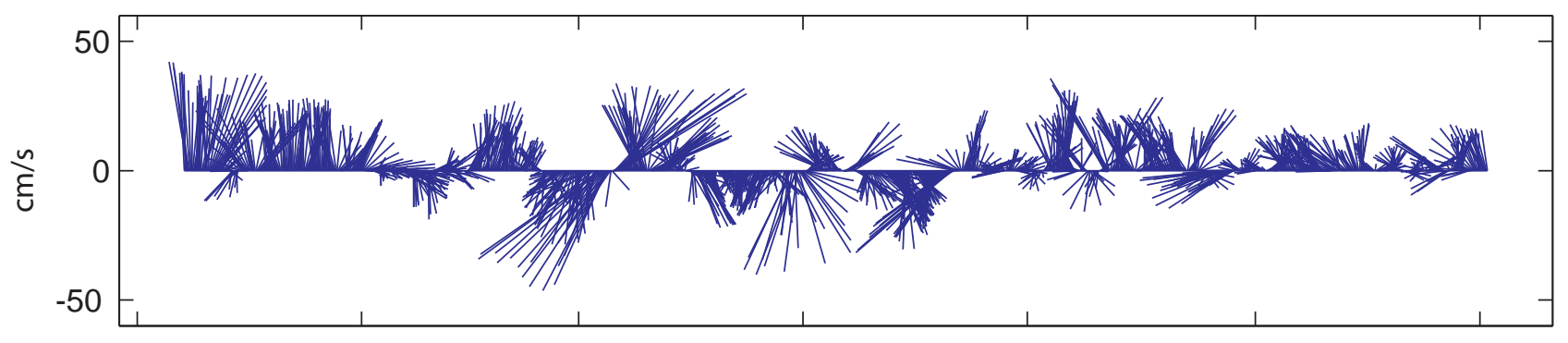

$\mathrm{D} 1,50 \mathrm{~m}$

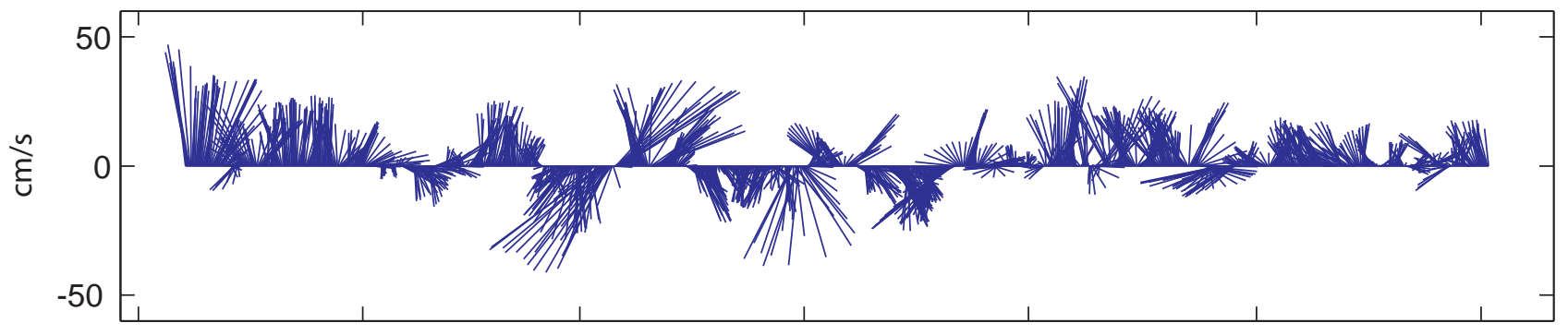

D1, $179 \mathrm{~m}$

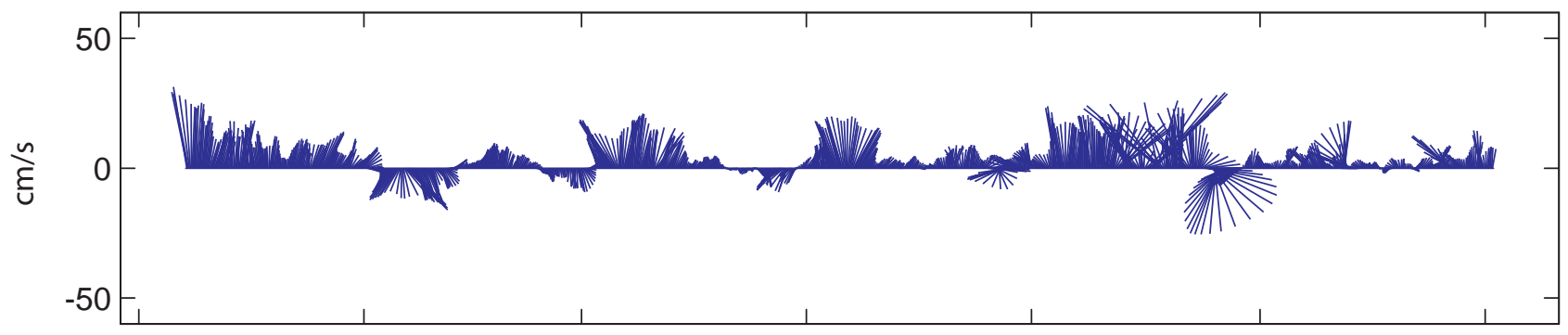

D1, $354 \mathrm{~m}$

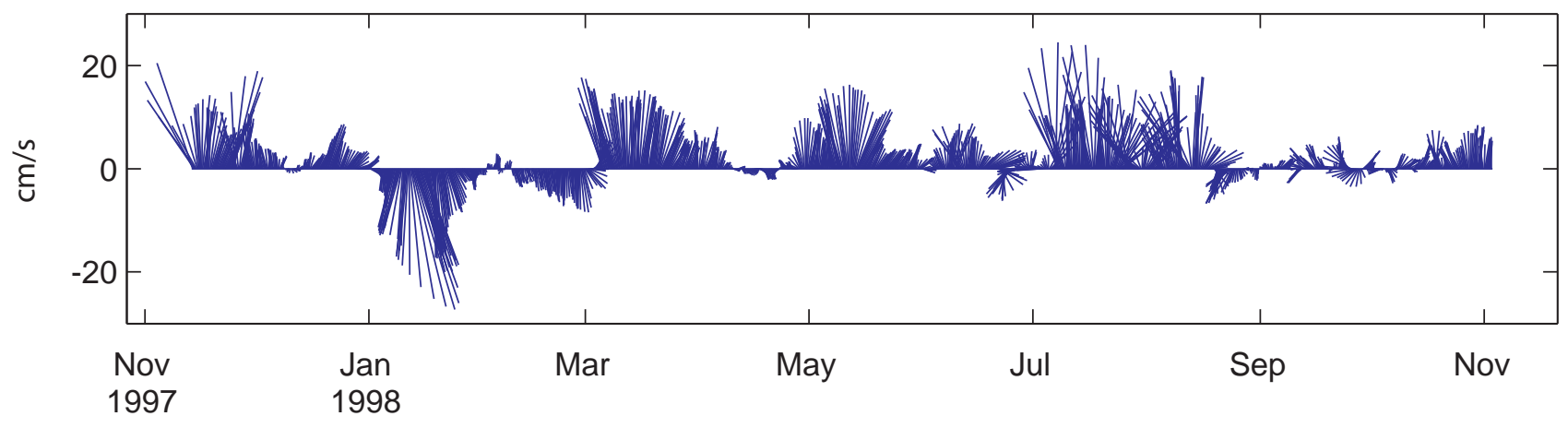

Figure C-1. Subtidal current vectors at Mooring D1. 

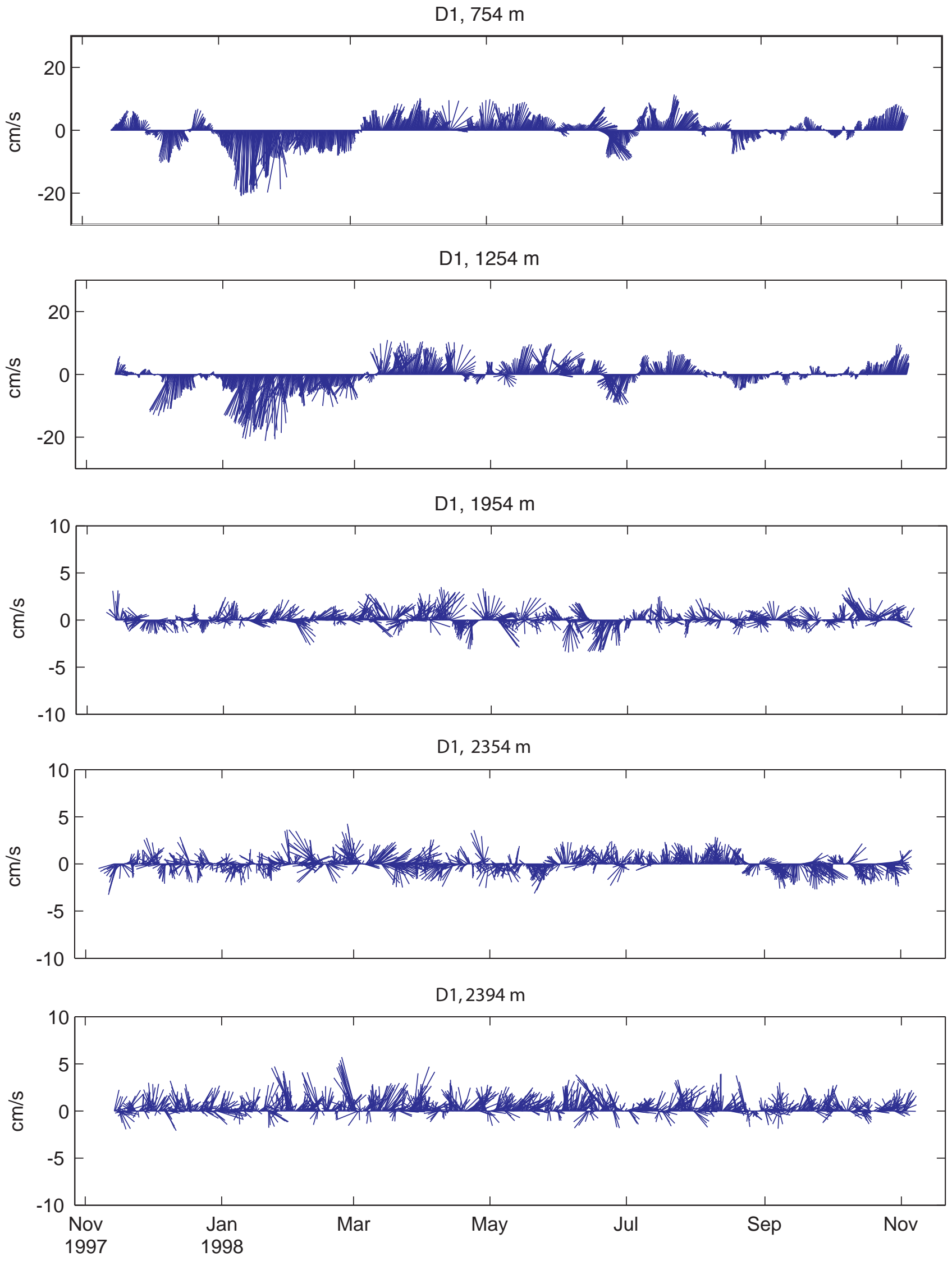

Figure C-1, cont. Subtidal current vectors at Mooring D1. 
$\mathrm{D} 2,90 \mathrm{~m}$

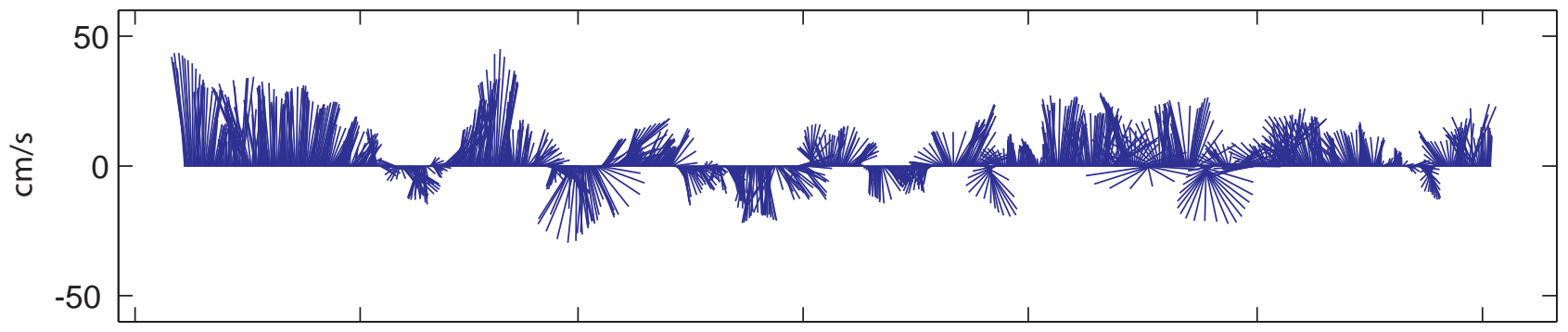

$\mathrm{D} 2,215 \mathrm{~m}$

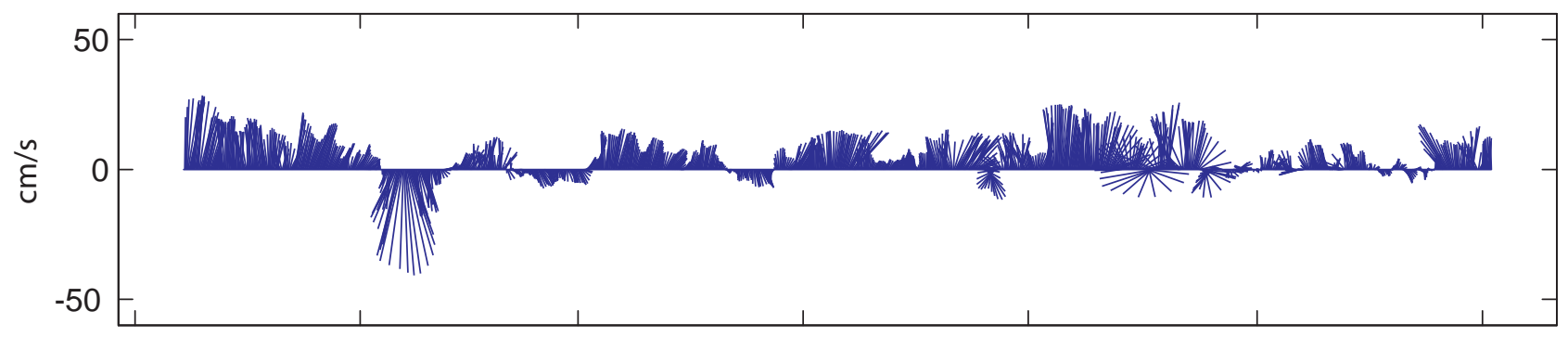

$\mathrm{D} 2,390 \mathrm{~m}$

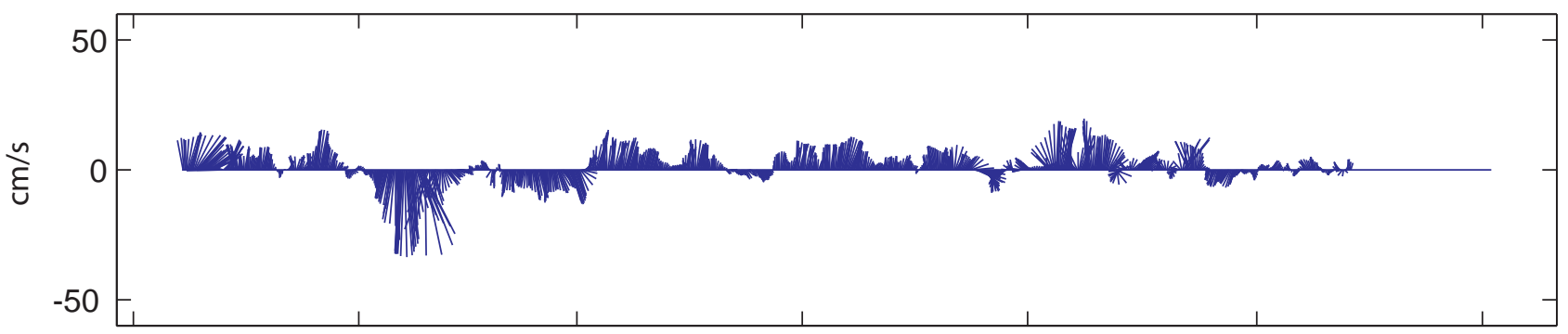

$\mathrm{D} 2,790 \mathrm{~m}$

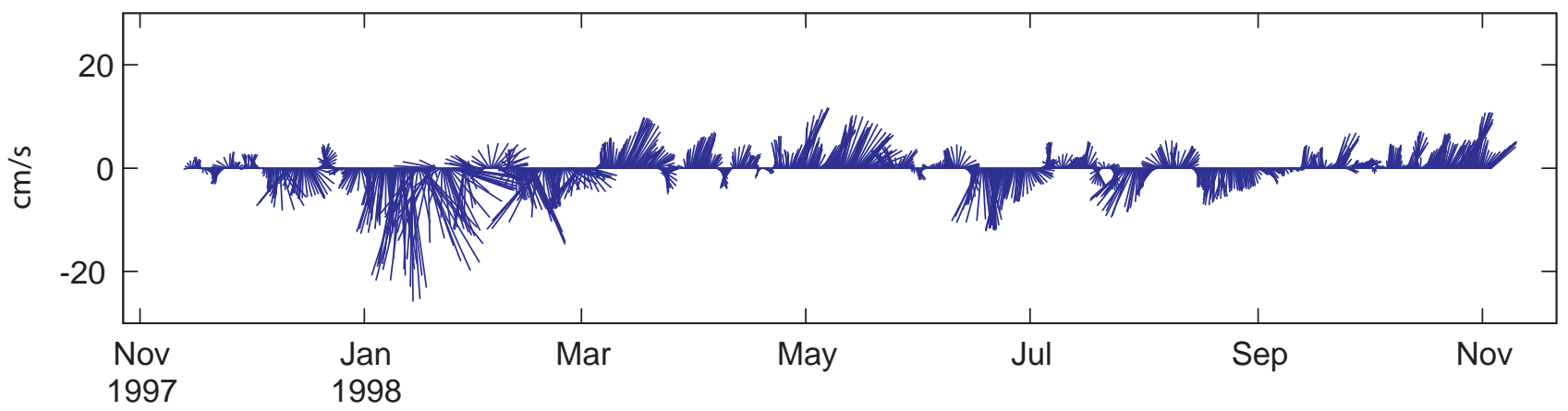

Figure C-2. Subtidal current vectors at Mooring D2. 
D2, $1140 \mathrm{~m}$

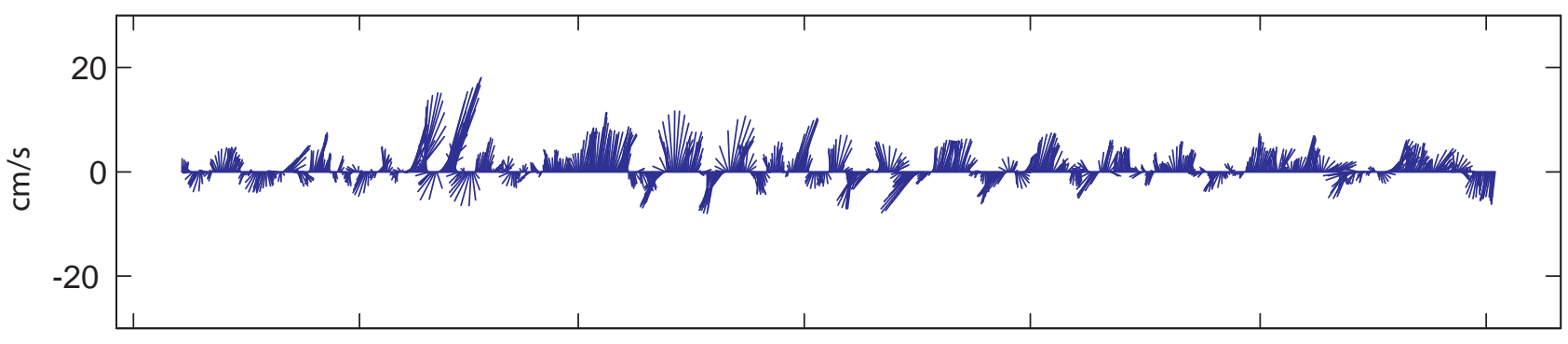

$\mathrm{D} 2,1180 \mathrm{~m}$

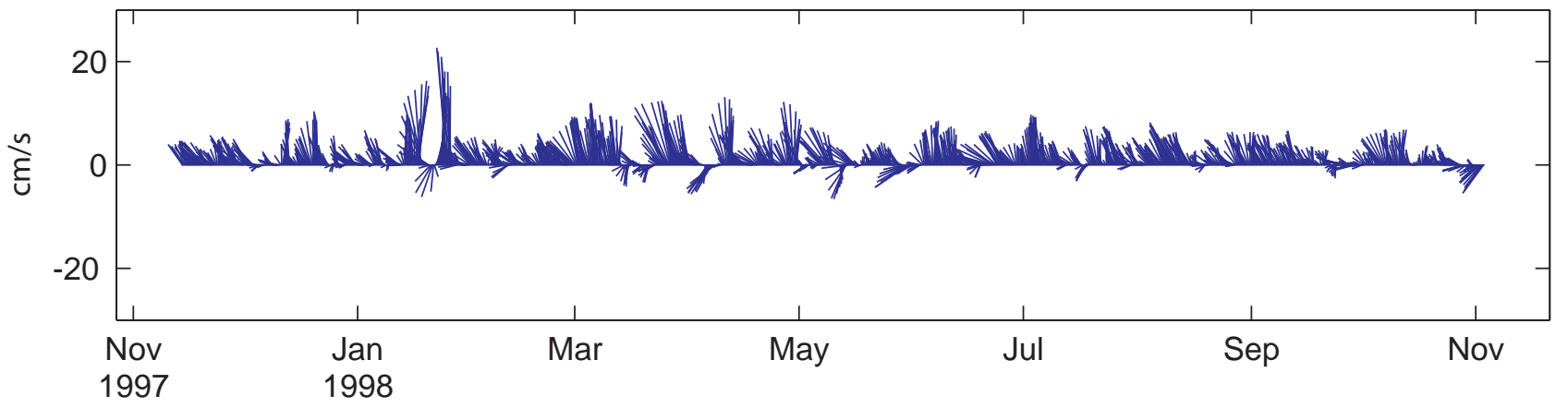

Figure C-2, cont. Subtidal current vectors at Mooring D2. 

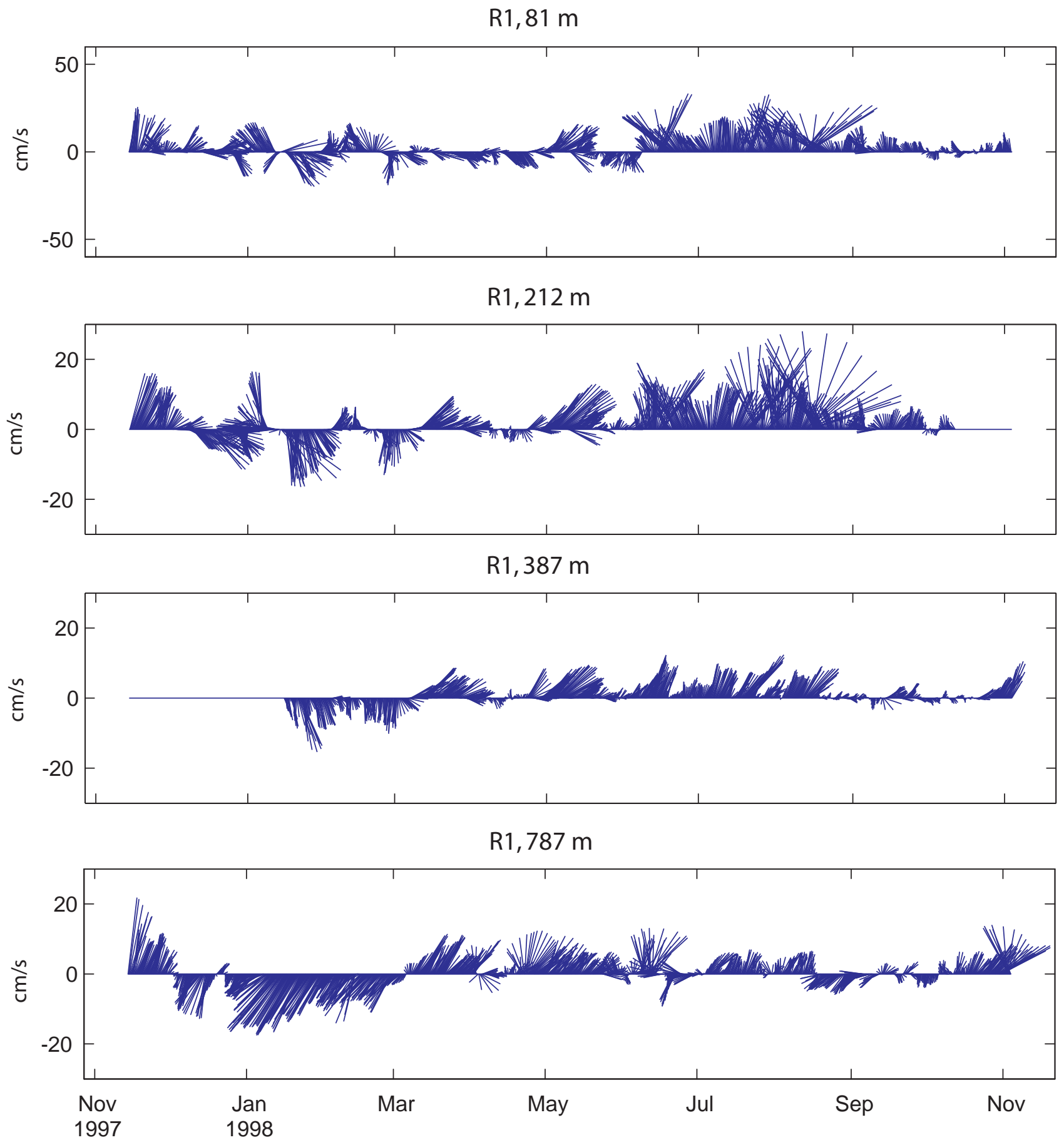

Figure C-3. Subtidal current vectors at Mooring R1. 

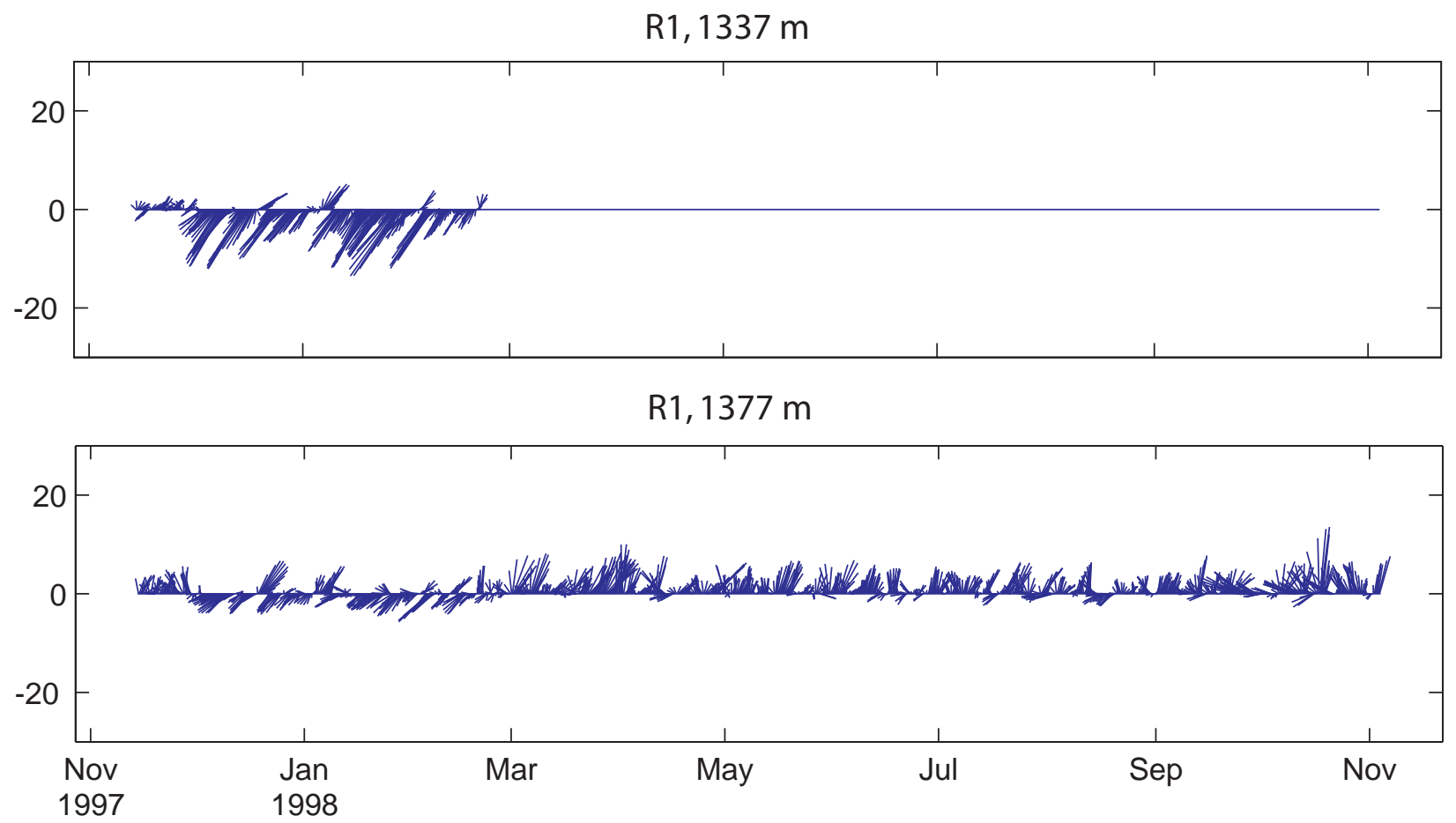

Figure C-3, cont. Subtidal current vectors at Mooring R1. 


\section{Appendix D.}

\section{Variance-conserving plots of spectra of}

along- and cross-slope currents 

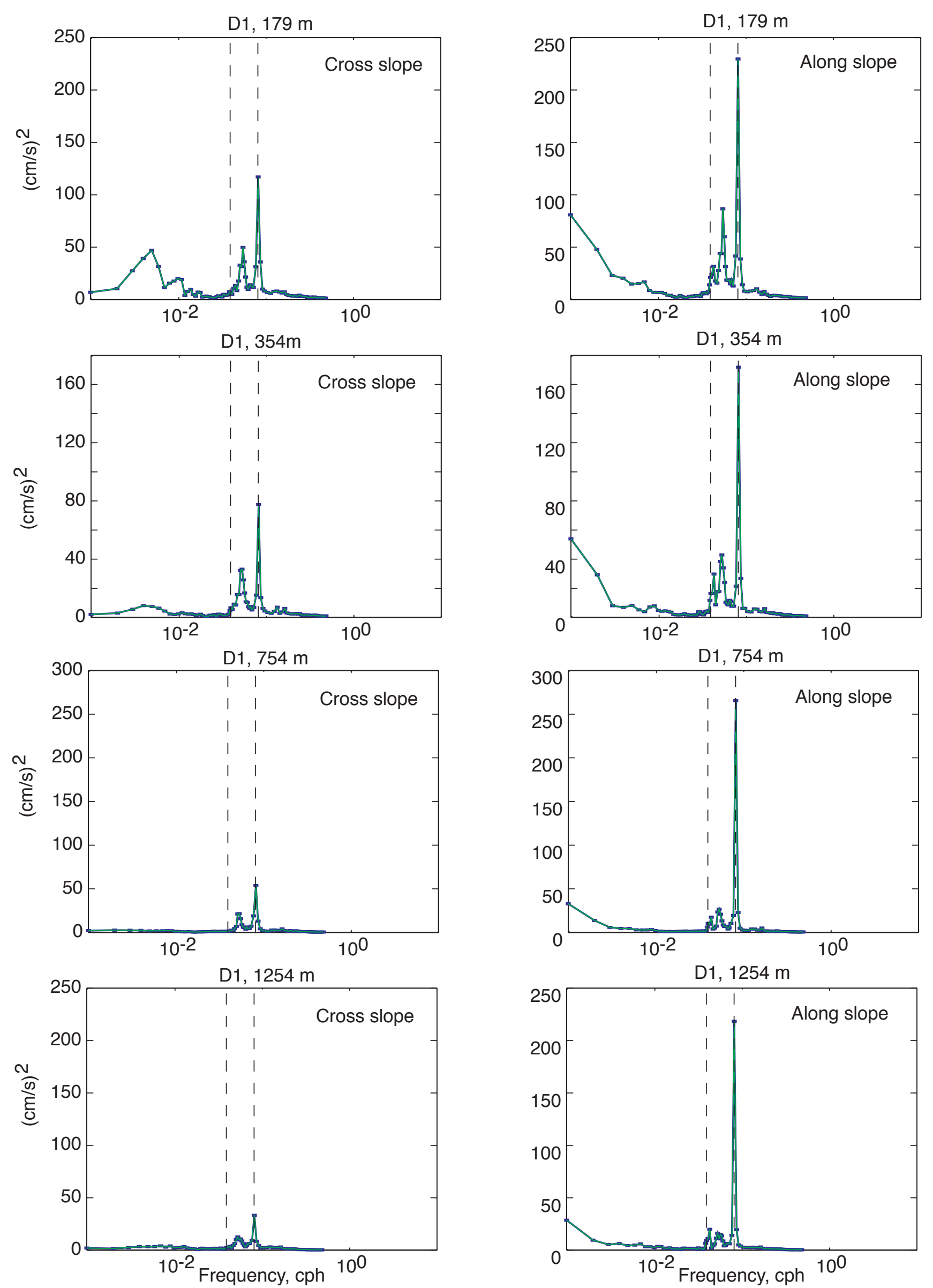

Figure D-1. Variance-conserving plots of spectra of along-and cross-slope currents at Mooring D1. The vertical dashed lines in the spectra denote the diurnal and semidiurnal tidal bands. 

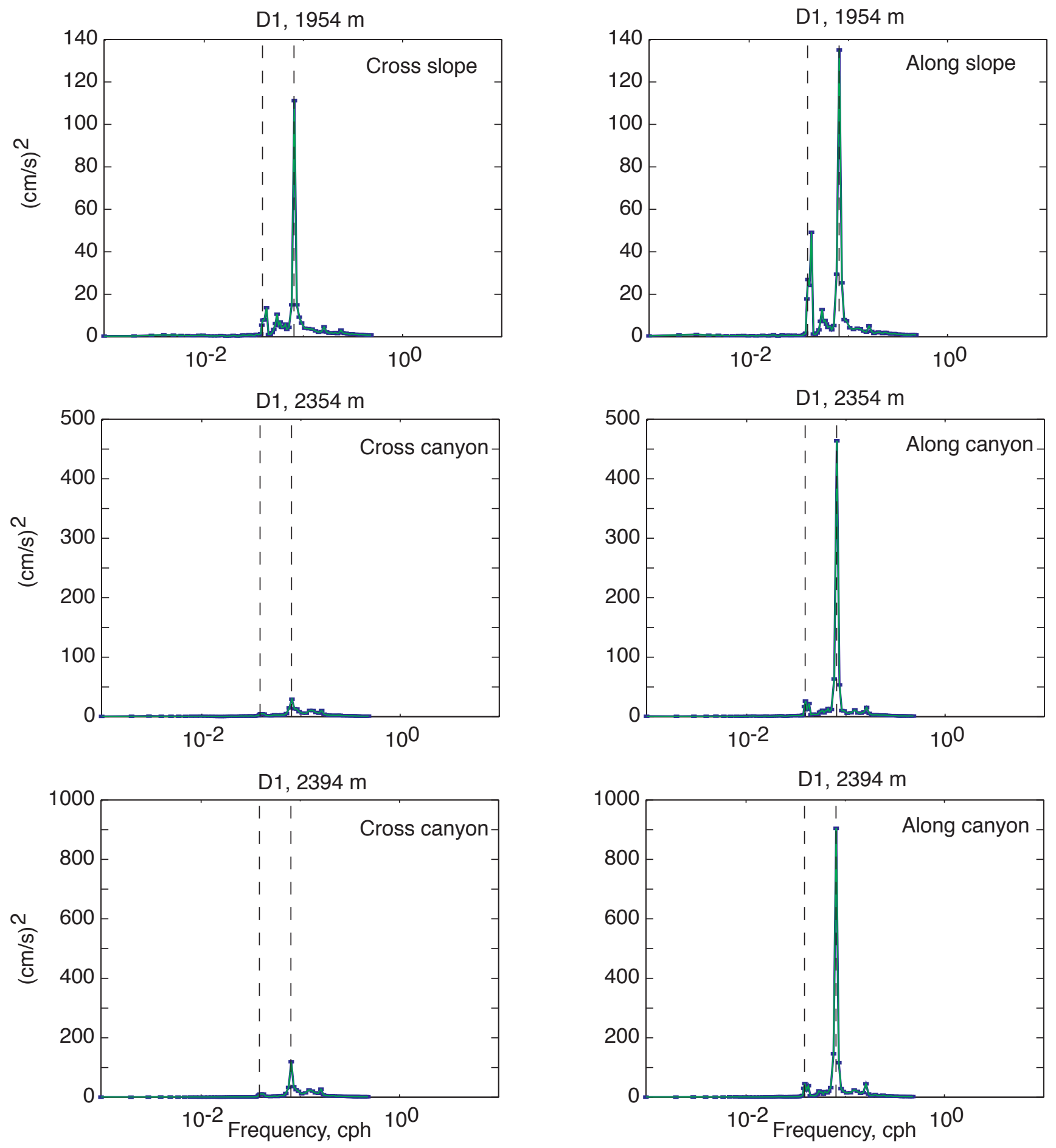

Figure D-1, cont. Variance-conserving plots of spectra of along-and cross-slope currents at Mooring D1. The vertical dashed lines in the spectra denote the diurnal and semidiurnal tidal bands. 

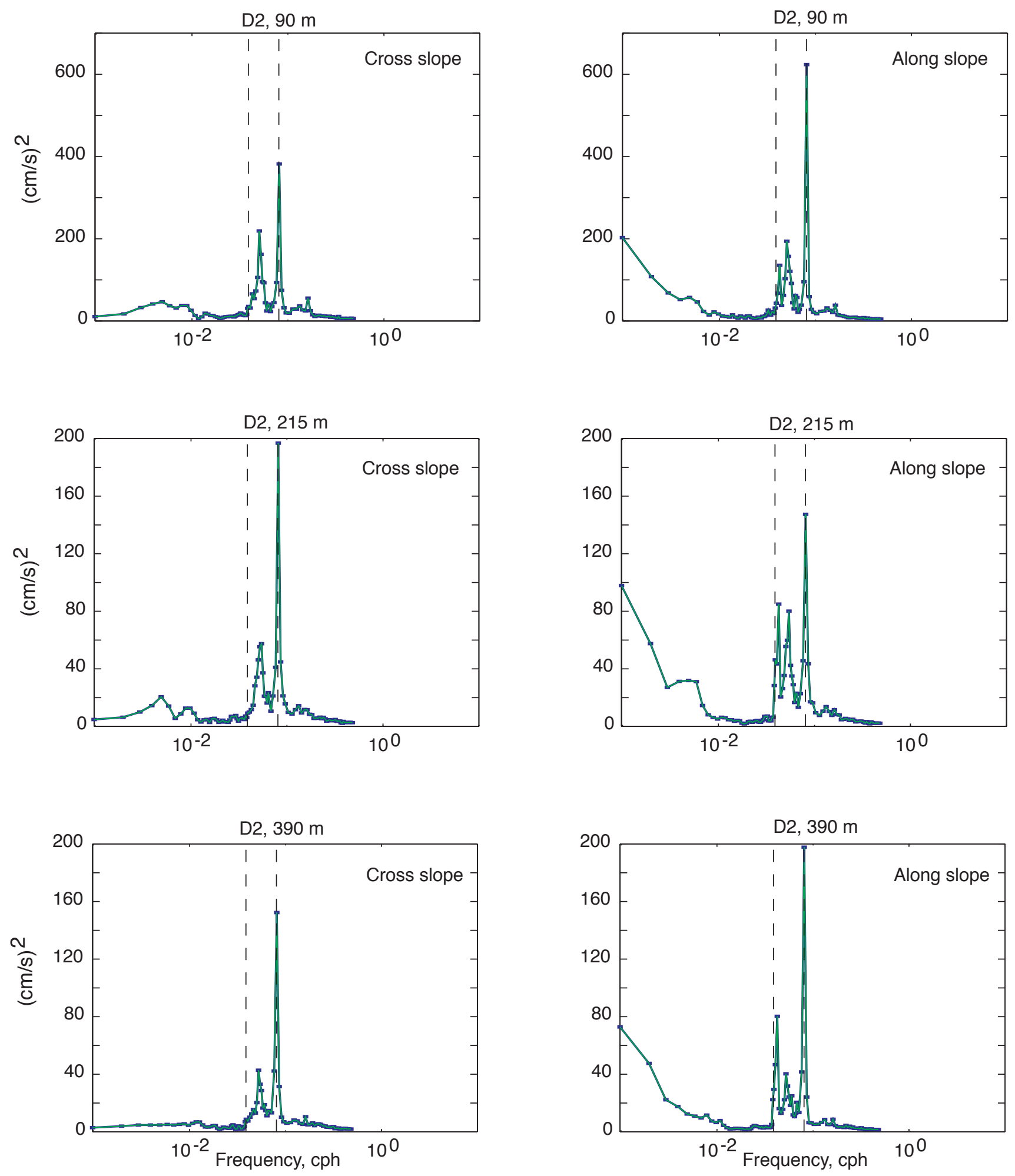

Figure D-2. Variance-conserving plots of spectra of along-and cross-slope currents at Mooring D2. The vertical dashed lines in the spectra denote the diurnal and semidiurnal tidal bands. 

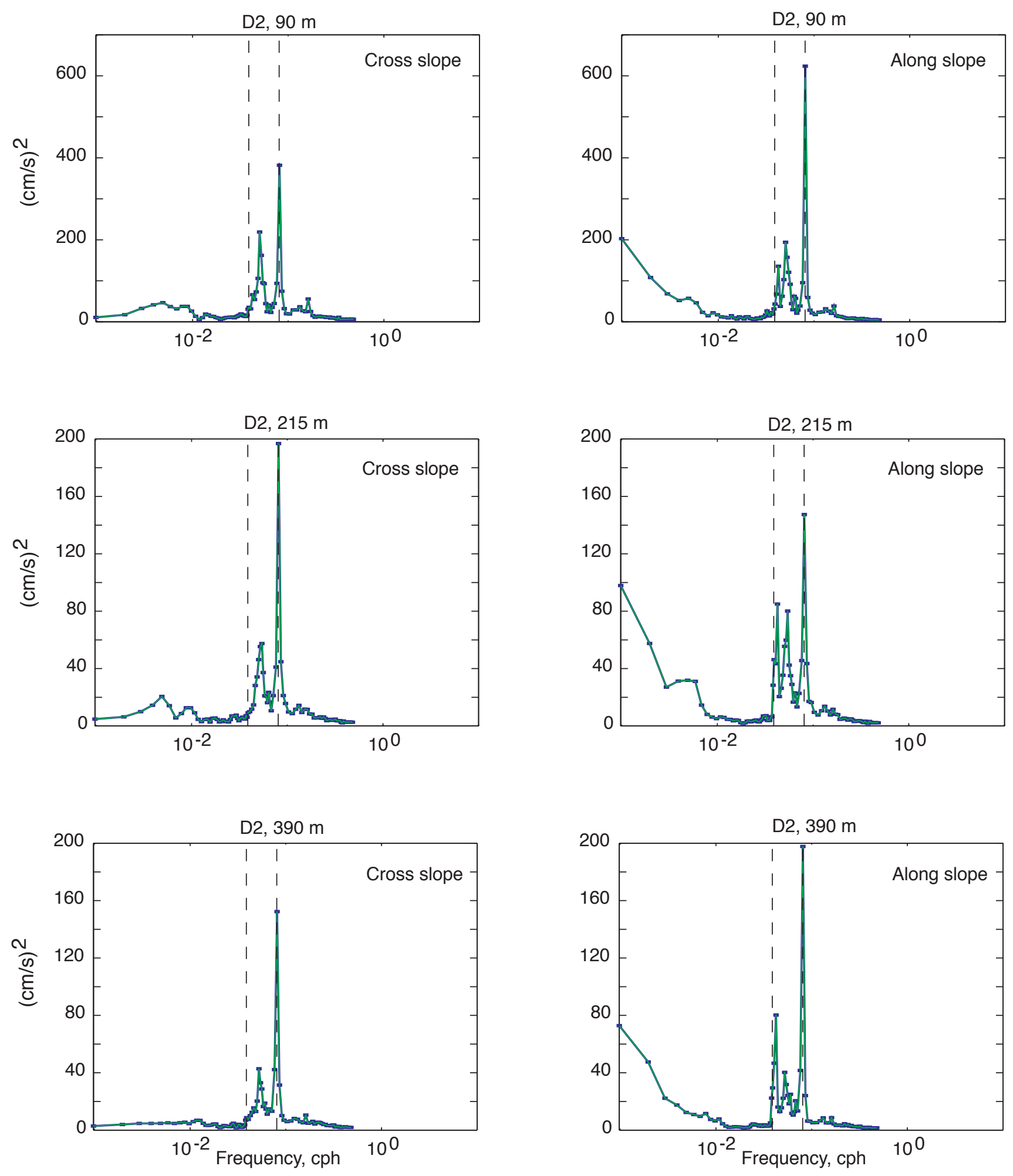

Figure D-2, cont. Variance-conserving plots of spectra of along-and cross-slope currents at Mooring D2. The vertical dashed lines in the spectra denote the diurnal and semidiurnal tidal bands. 

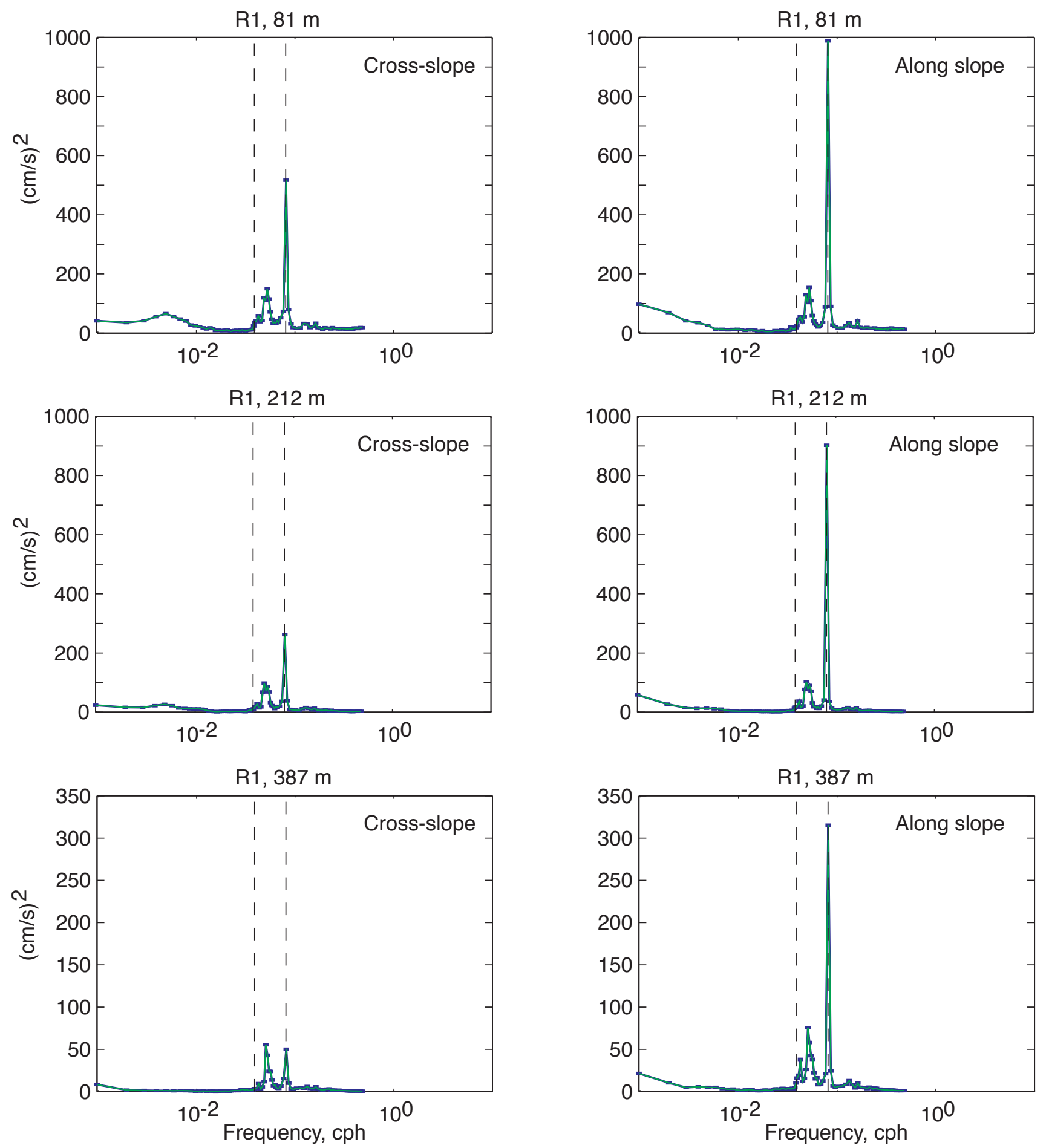

Figure D-3. Variance-conserving plots of spectra of along-and cross-slope currents at Mooring R1. The vertical dashed lines in the spectra denote the diurnal and semidiurnal tidal bands. 

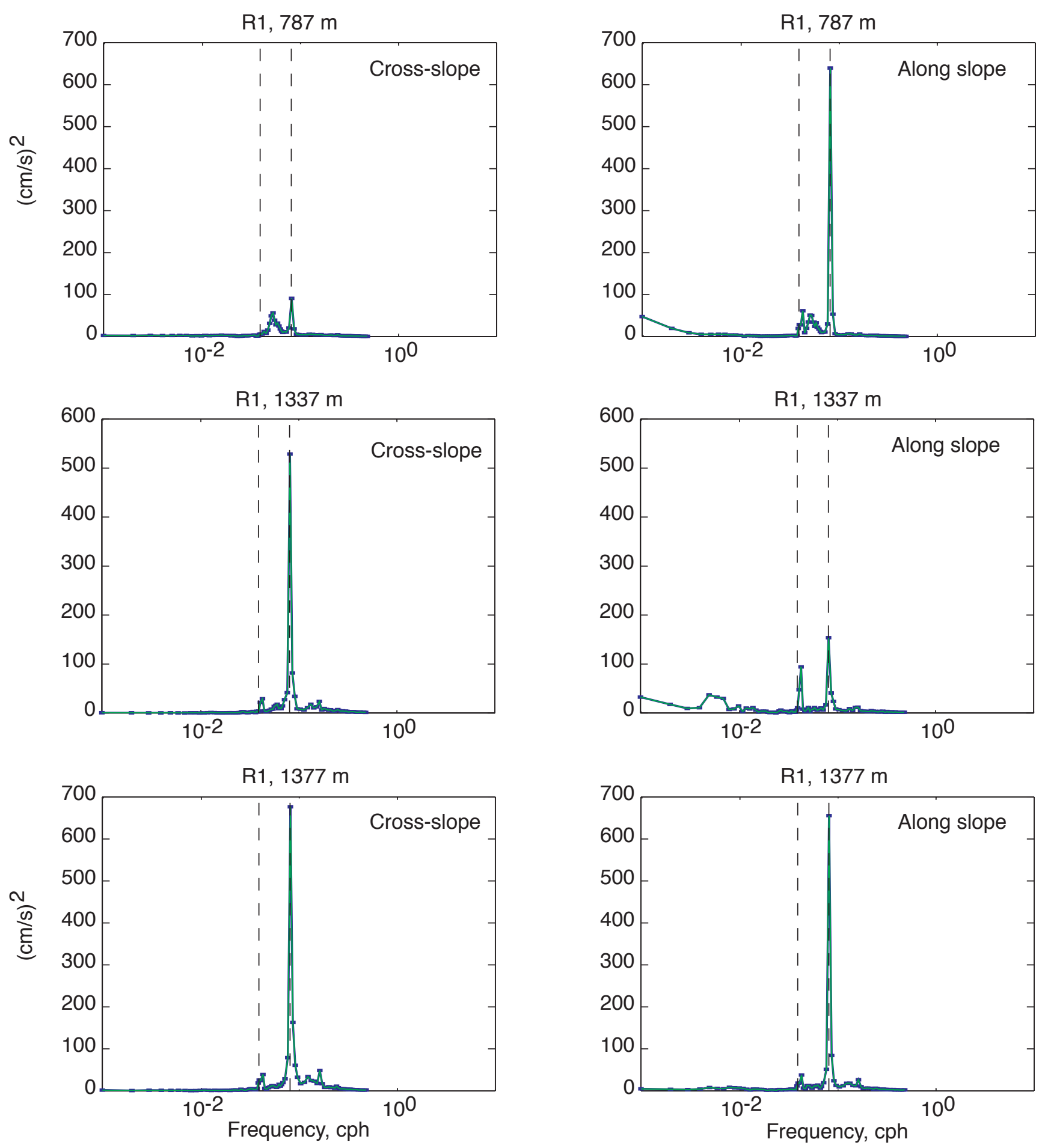

Figure D-3, cont. Variance-conserving plots of spectra of along-and cross-slope currents at Mooring R1. The vertical dashed lines in the spectra denote the diurnal and semidiurnal tidal bands. 
Appendix E.

Temperature, salinity, and transmission plots 
Table E-1. Basic statistics for the temperature and salinity records at all moorings. Depths where readings were not taken are labeled by a dash.

\begin{tabular}{|c|c|c|c|c|c|c|}
\hline \multirow{2}{*}{$\begin{array}{l}\text { Mooring } \\
\text { and depth } \\
\text { (m) }\end{array}$} & \multicolumn{3}{|c|}{ Temperature } & \multicolumn{3}{|c|}{ Salinity } \\
\hline & Mean & Error Bar & STDV & Mean & Error Bar & STDV \\
\hline \multicolumn{7}{|l|}{ D1 } \\
\hline $50 \mathrm{~m}$ & - & - & - & 32.8 & 0.34 & 0.4 \\
\hline $179 \mathrm{~m}$ & 8.8 & 0.5 & 0.6 & - & - & - \\
\hline $354 \mathrm{~m}$ & 6.7 & 0.4 & 0.5 & - & - & - \\
\hline $754 \mathrm{~m}$ & 4.5 & 0.1 & 0.2 & - & - & - \\
\hline $1254 \mathrm{~m}$ & 3.2 & 0.1 & 0.1 & - & - & - \\
\hline $1954 \mathrm{~m}$ & 2.1 & 0.1 & 0.1 & - & - & - \\
\hline $2354 \mathrm{~m}$ & 1.8 & 0.0 & 0.0 & - & - & - \\
\hline $2394 \mathrm{~m}$ & 1.8 & 0.0 & 0.0 & 34.7 & 0.0 & 0.0 \\
\hline \multicolumn{7}{|l|}{ D2 } \\
\hline $90 \mathrm{~m}$ & 11.2 & 1.8 & 1.4 & 33.5 & 0.2 & 0.2 \\
\hline $215 \mathrm{~m}$ & 8.4 & 0.6 & 0.7 & - & - & - \\
\hline $390 \mathrm{~m}$ & 6.5 & 0.4 & 0.5 & - & - & - \\
\hline $790 \mathrm{~m}$ & 4.4 & 0.1 & 0.2 & - & - & - \\
\hline $1140 \mathrm{~m}$ & 3.4 & 0.1 & 0.1 & - & - & - \\
\hline $1180 \mathrm{~m}$ & 3.3 & 0.1 & 0.1 & 34.3 & 0.1 & 0.2 \\
\hline \multicolumn{7}{|l|}{ R1 } \\
\hline $81 \mathrm{~m}$ & 11.2 & 2.2 & 1.4 & 33.4 & 0.3 & 0.2 \\
\hline $212 \mathrm{~m}$ & 8.3 & 0.6 & 0.6 & - & - & - \\
\hline $387 \mathrm{~m}$ & 6.3 & 0.3 & 0.4 & - & - & - \\
\hline $787 \mathrm{~m}$ & 4.4 & 0.1 & 0.3 & - & - & - \\
\hline $1337 \mathrm{~m}$ & 3.0 & 0.2 & 0.1 & - & - & - \\
\hline $1377 \mathrm{~m}$ & 2.9 & 0.1 & 0.1 & 34.6 & 0.0 & 0.0 \\
\hline
\end{tabular}



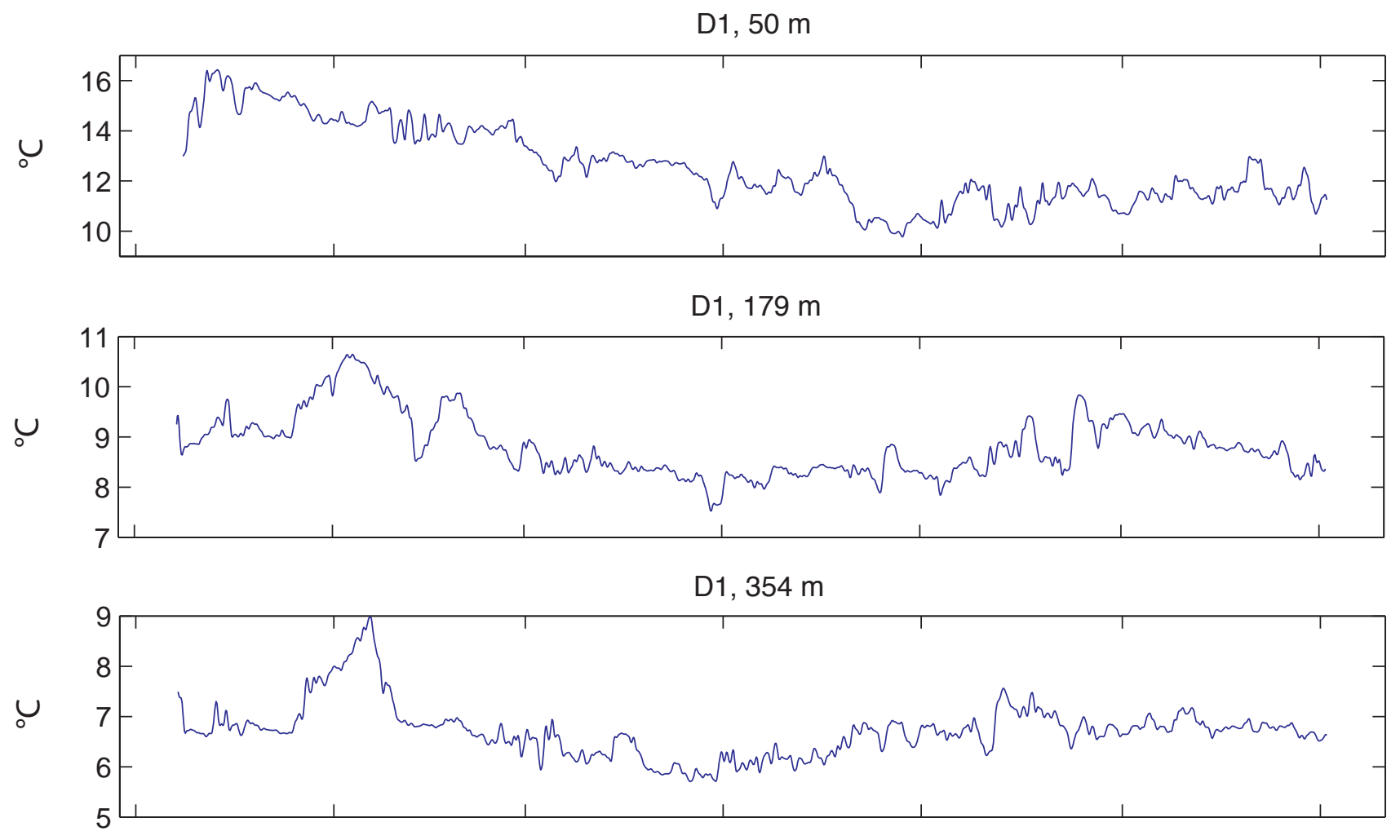

\section{D1, 754 m}

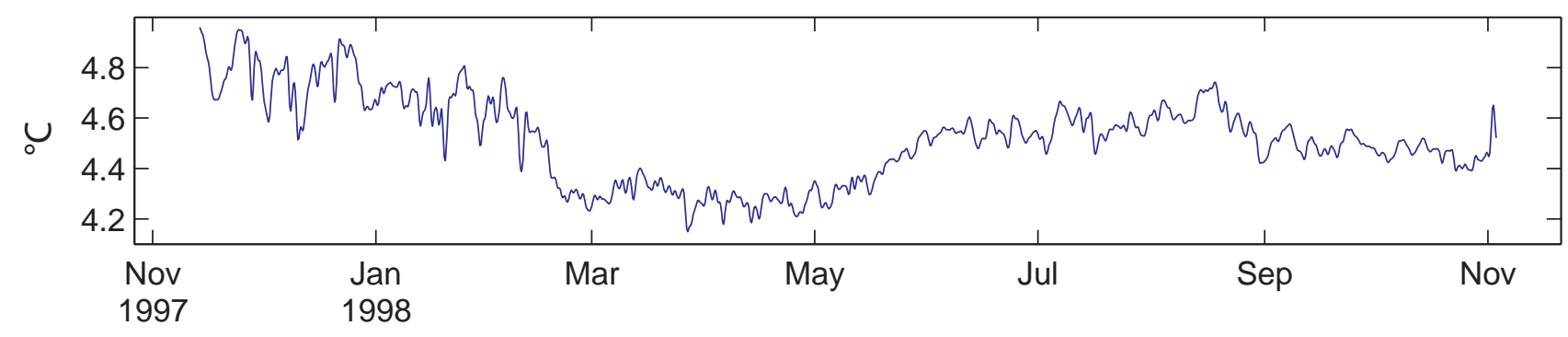

Figure E-1. Temperature plots at Moorings D1, D2, and R1. 
D1, 1254 m

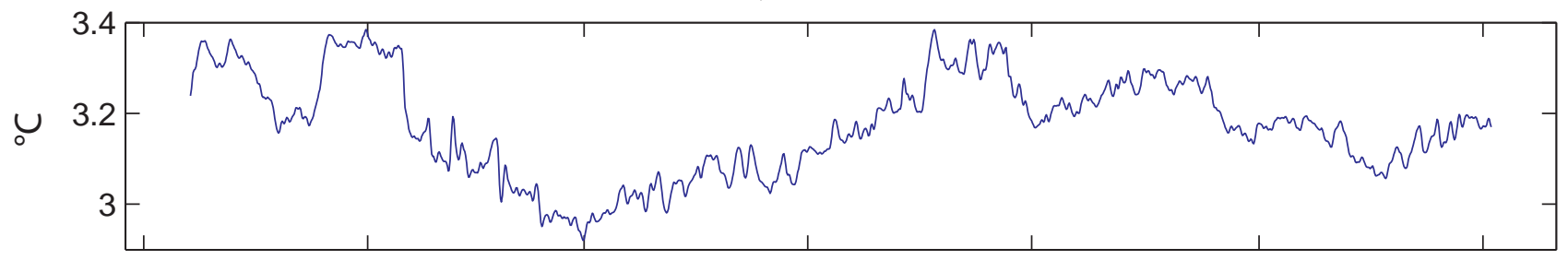

D1, 1954 m
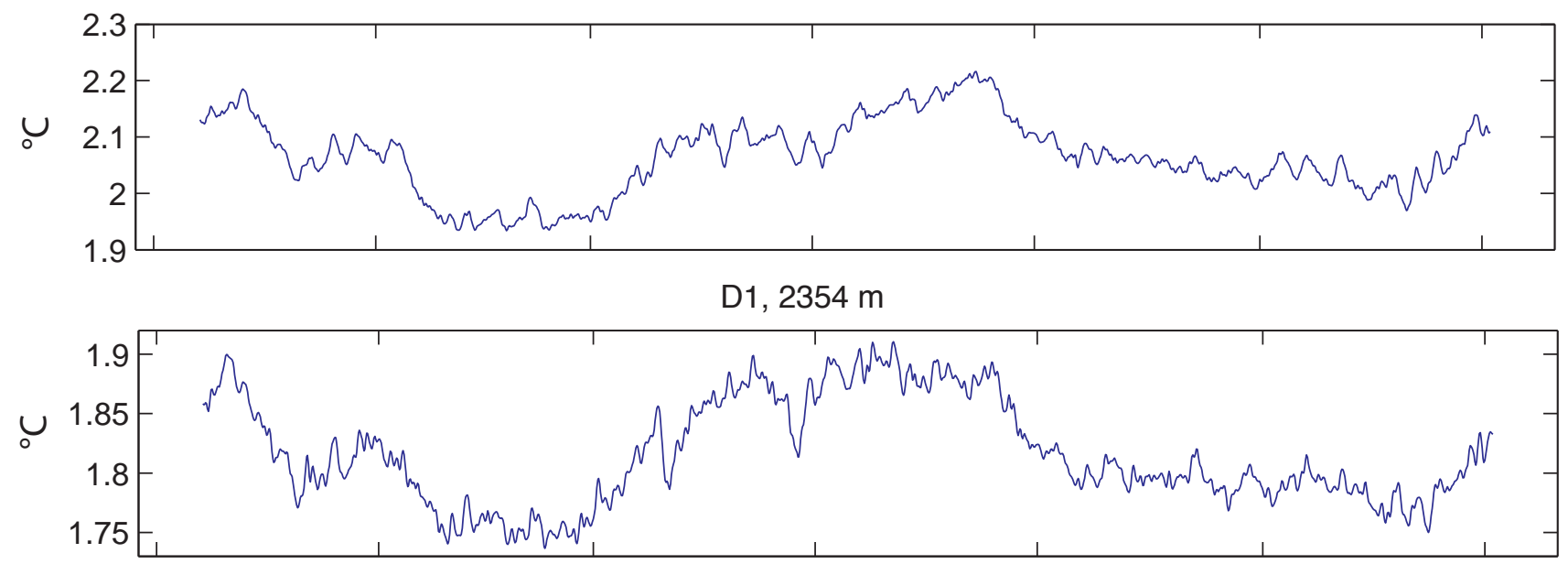

D1, 2394 m

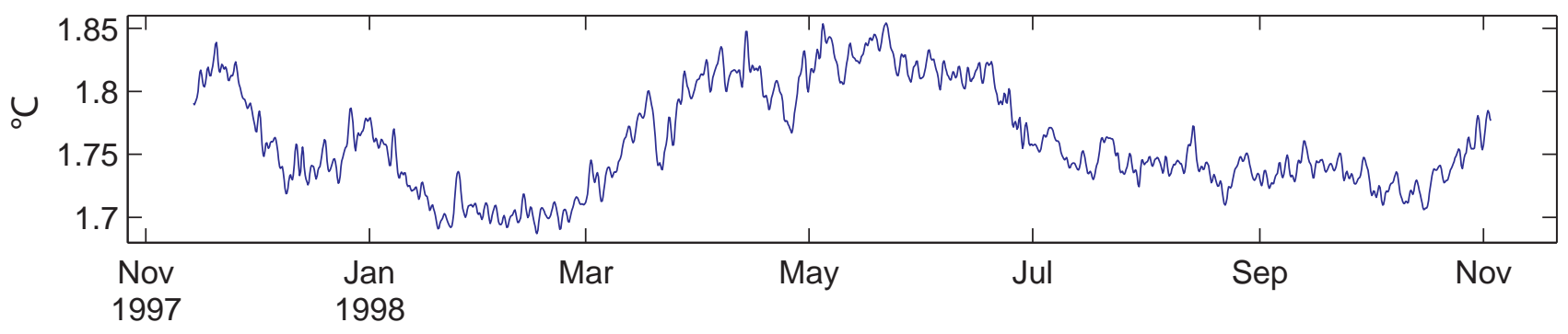

Figure E-1, cont. Temperature plots at Moorings D1, D2, and R1. 
D2, $90 \mathrm{~m}$

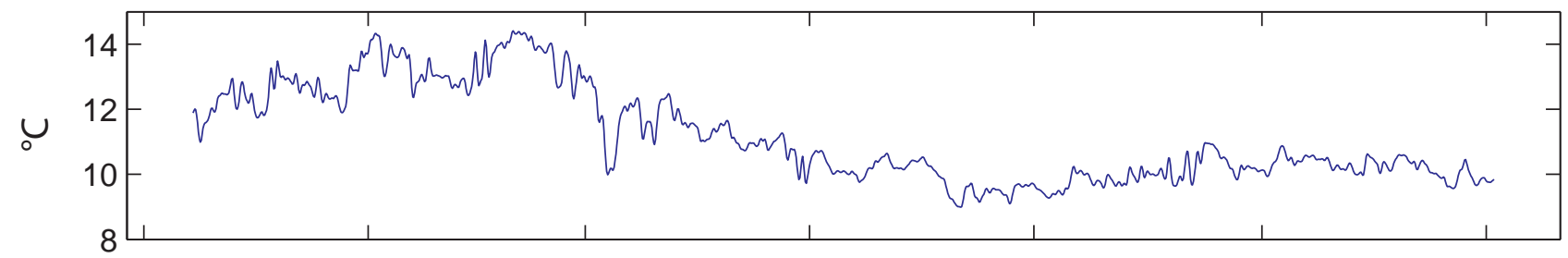

D2, $215 \mathrm{~m}$
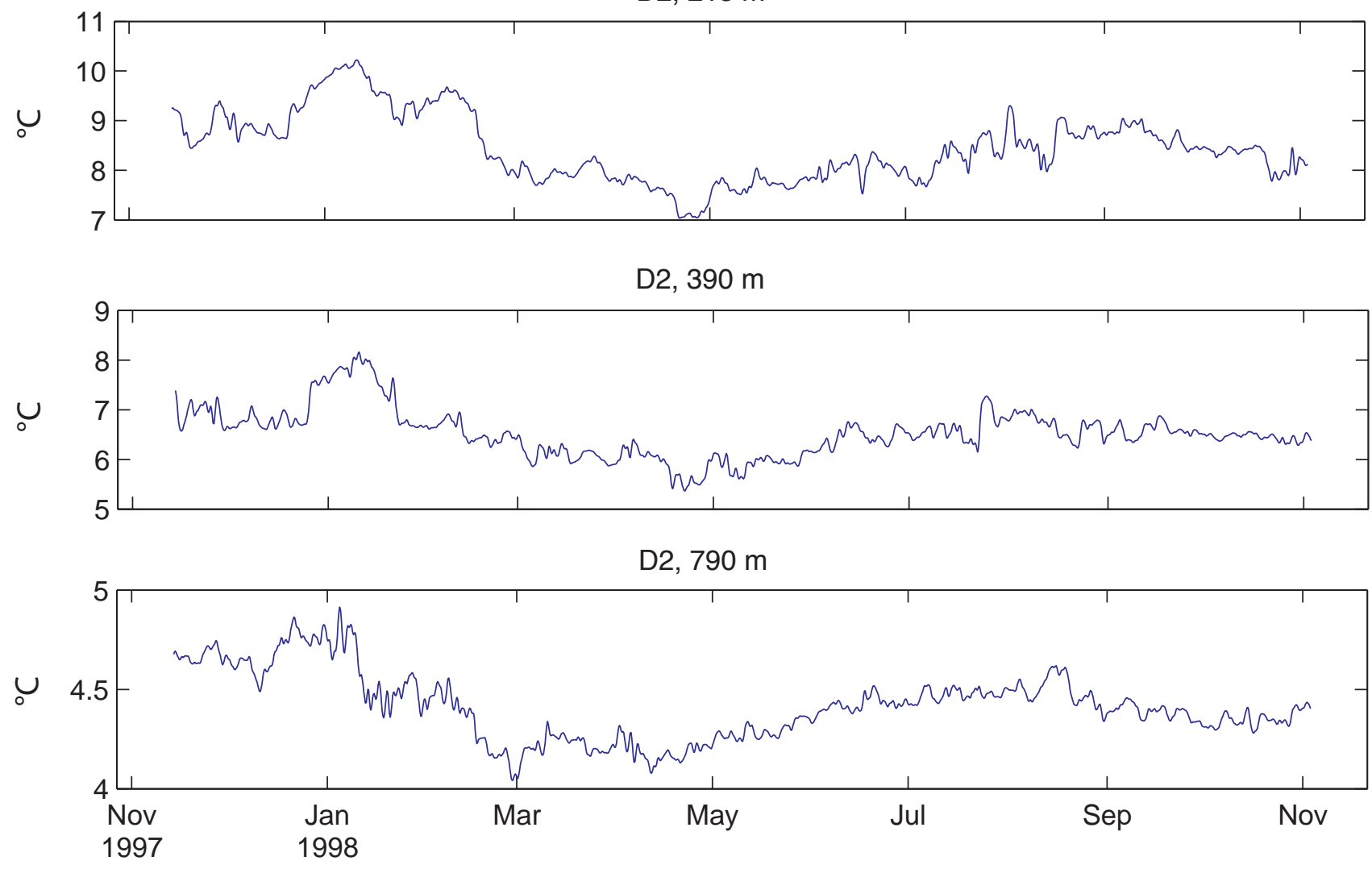

Figure E-1, cont. Temperature plots at Moorings D1, D2, and R1. 


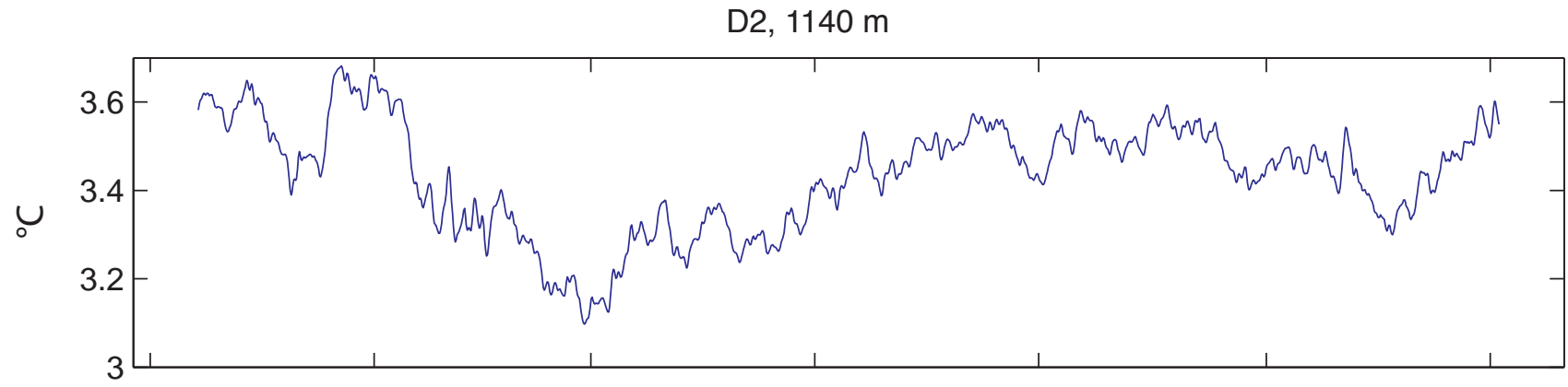

D2, $1180 \mathrm{~m}$

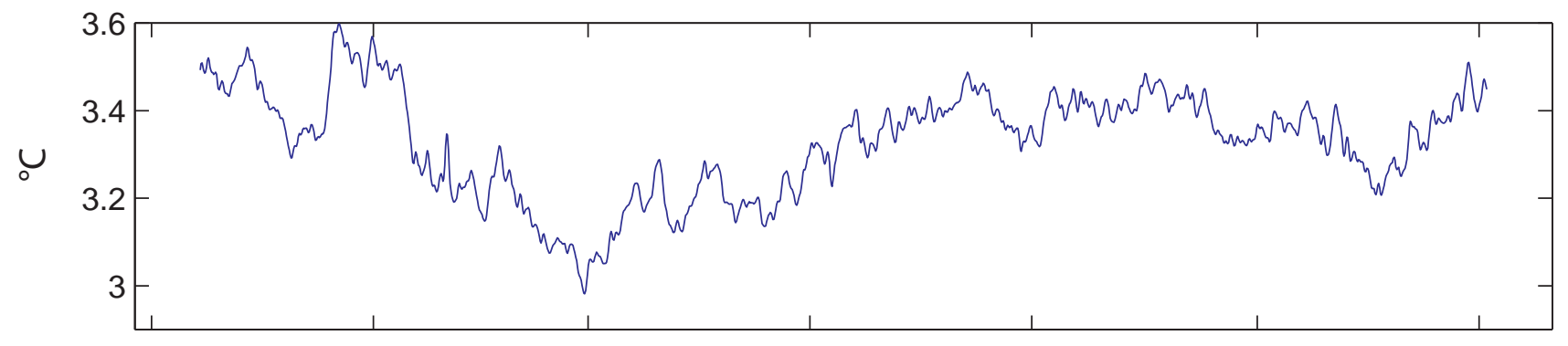

Figure E-1, cont. Temperature plots at Moorings D1, D2, and R1. 
$\mathrm{R} 1,81 \mathrm{~m}$

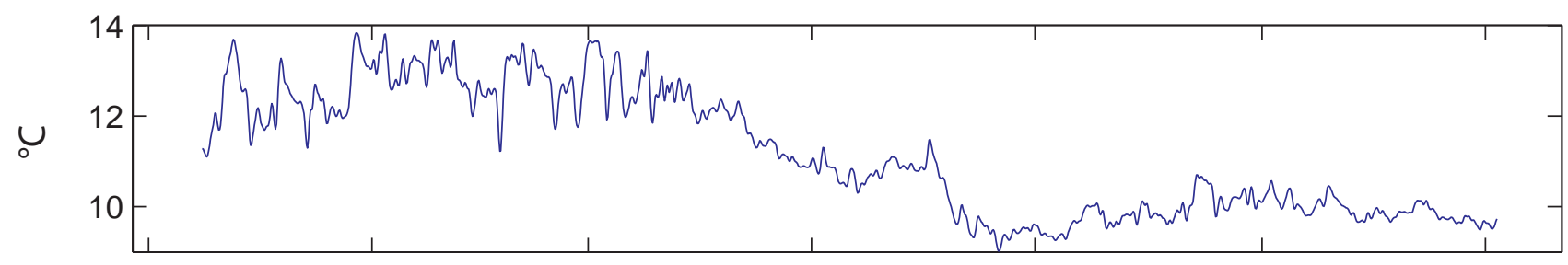

R1, 212 m

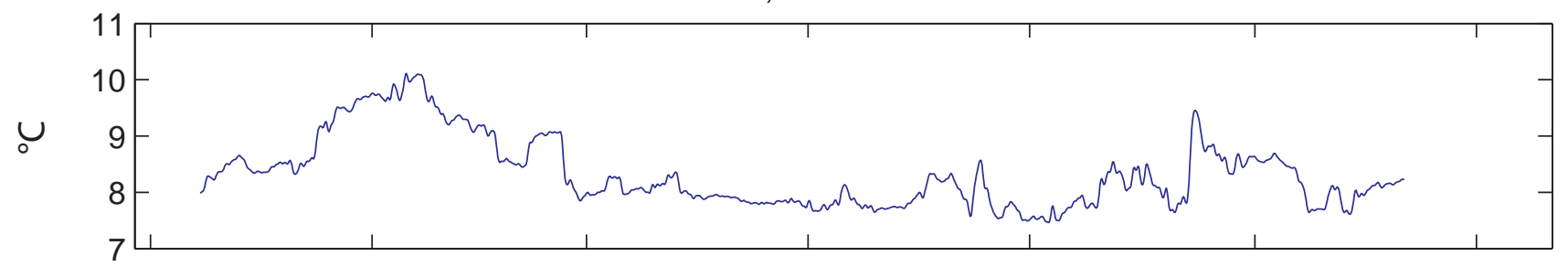

R1, 387 m

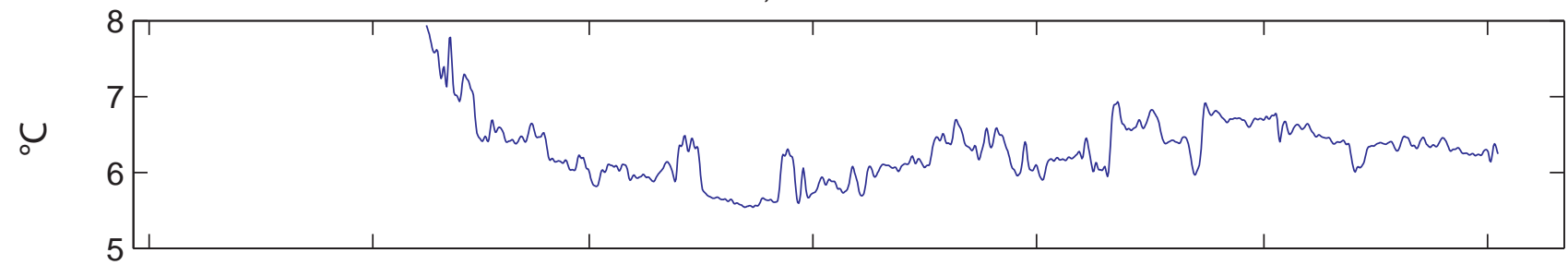

R1, 787 m

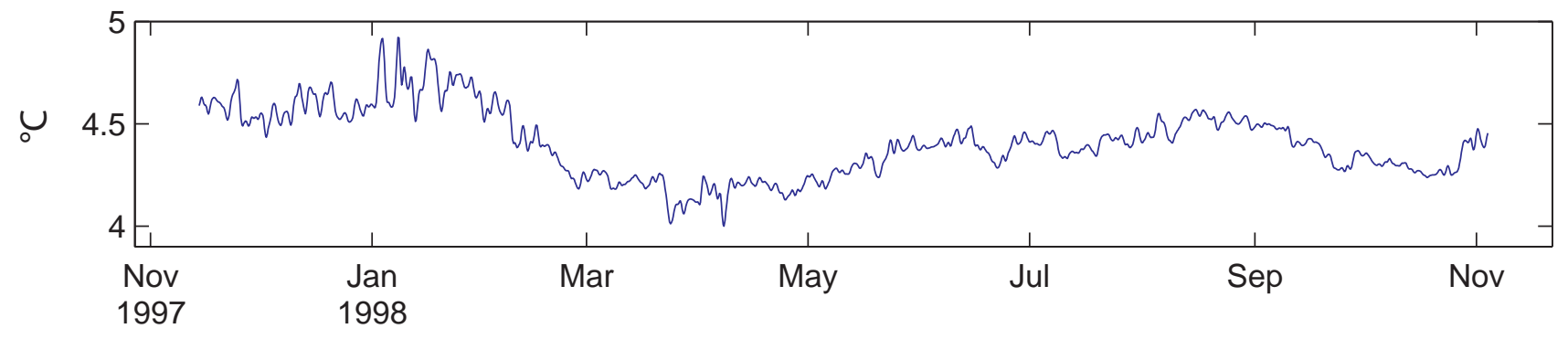

Figure E-1, cont. Temperature plots at Moorings D1, D2, and R1. 
R1, 1337 m

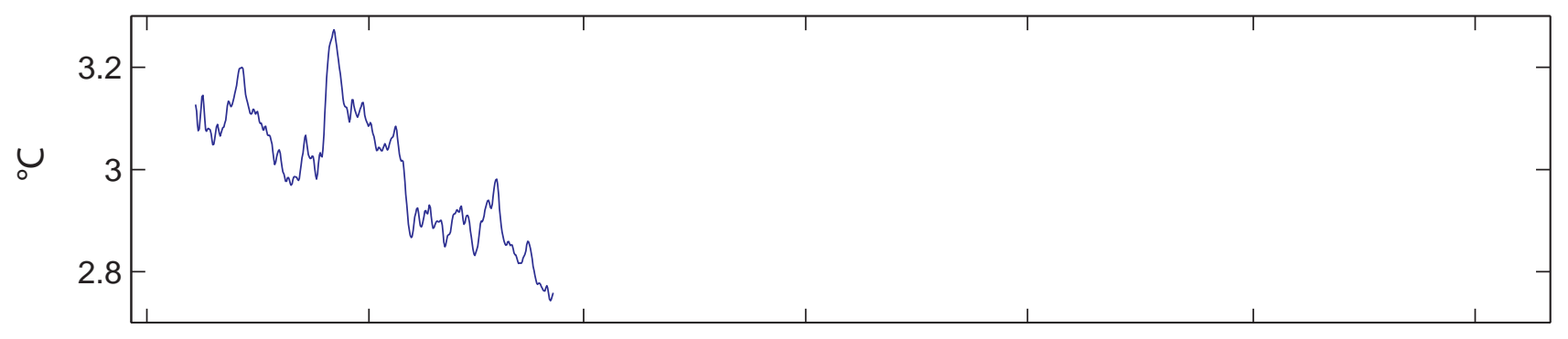

R1, 1377 m

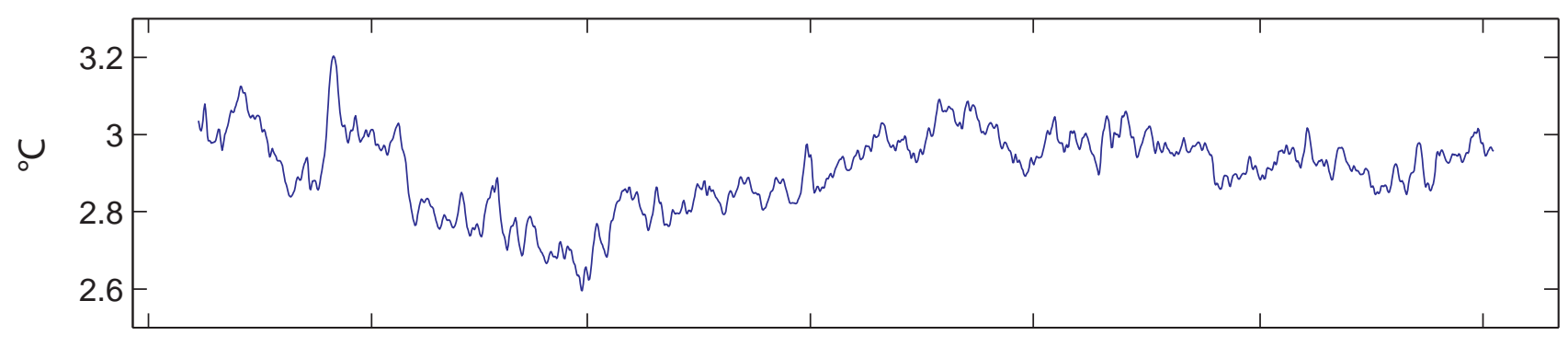

Figure E-1, cont. Temperature plots at Moorings D1, D2, and R1. 

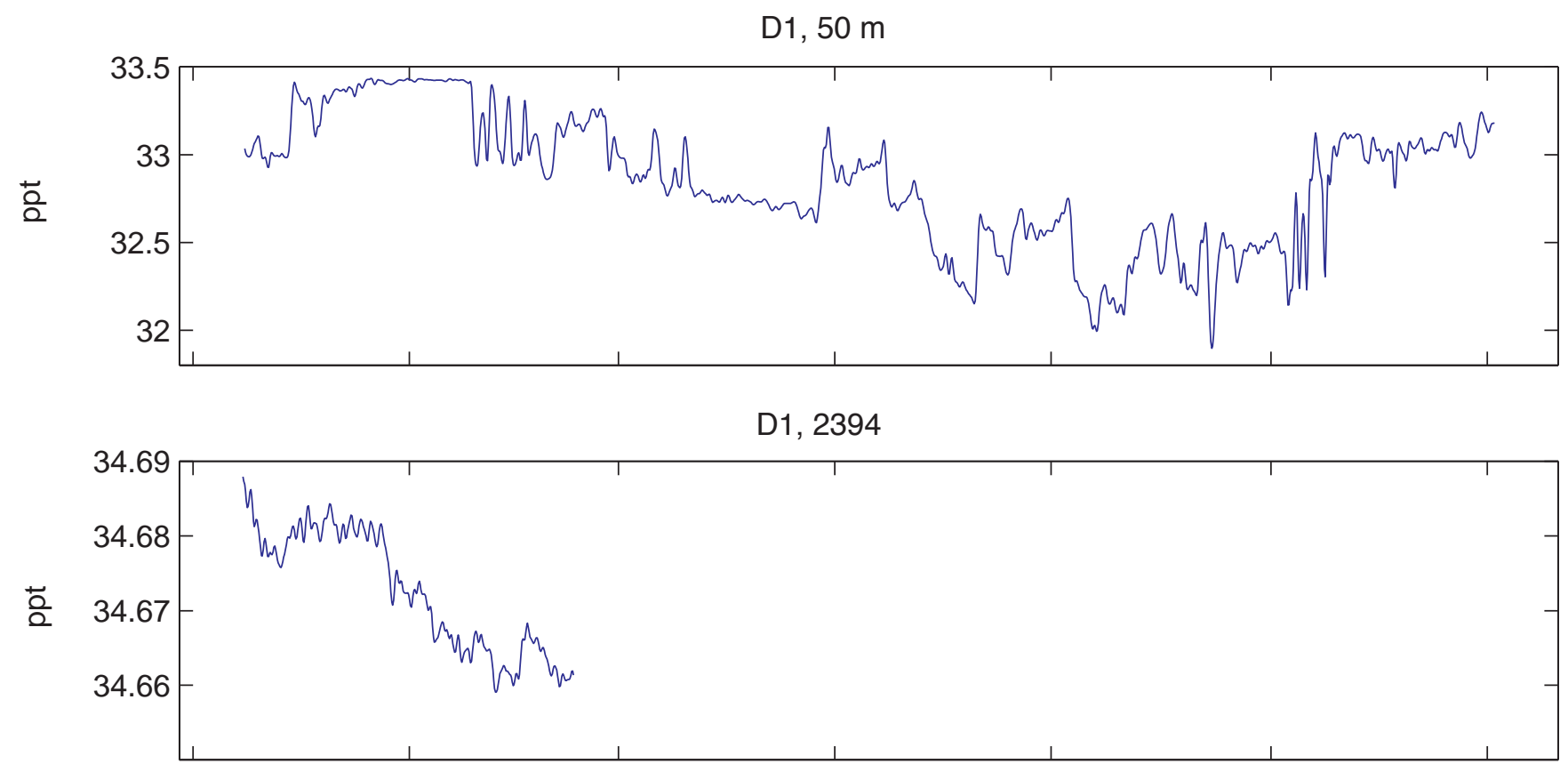

D2, $90 \mathrm{~m}$

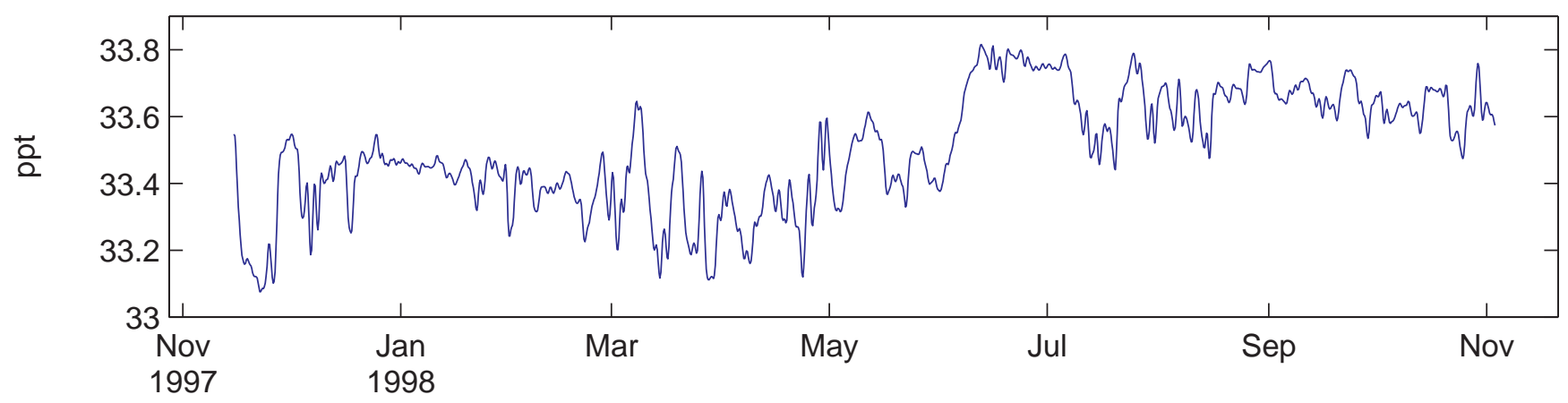

Figure E-2. Salinity plots at Moorings D1, D2, and R1. 
D2, $1180 \mathrm{~m}$
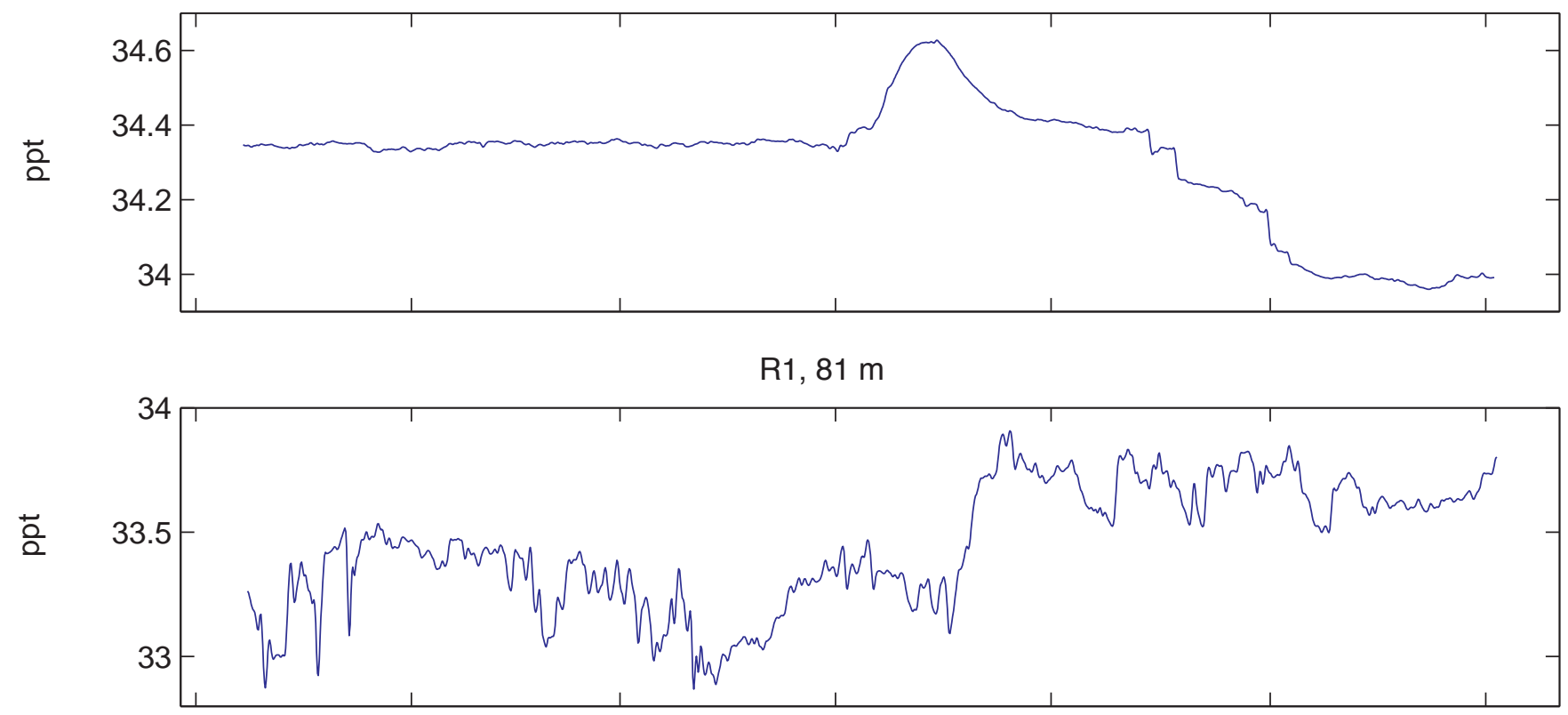

R1, 1377 m

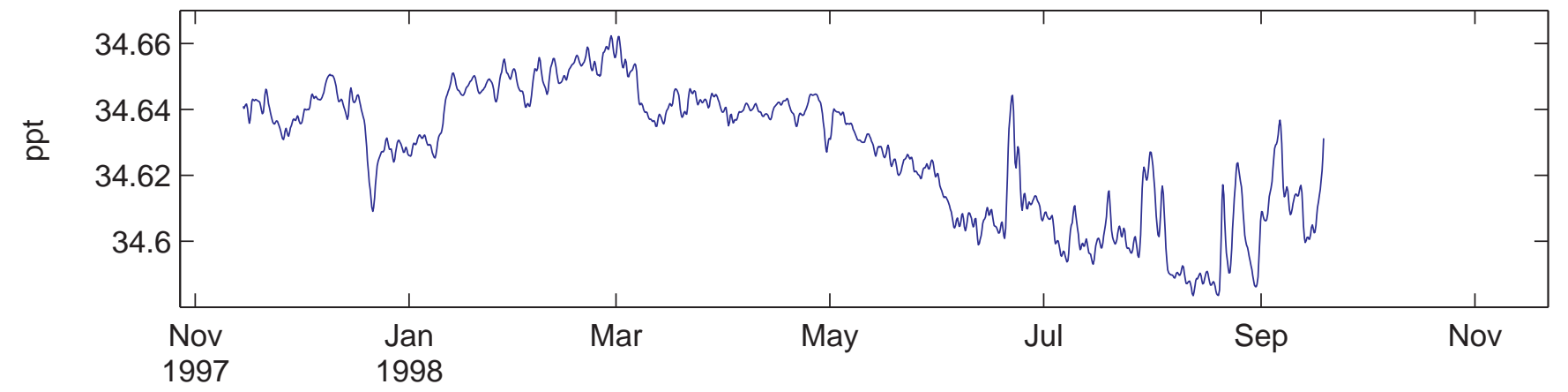

Figure E-2, cont. Salinity plots at Moorings D1, D2, and R1. 

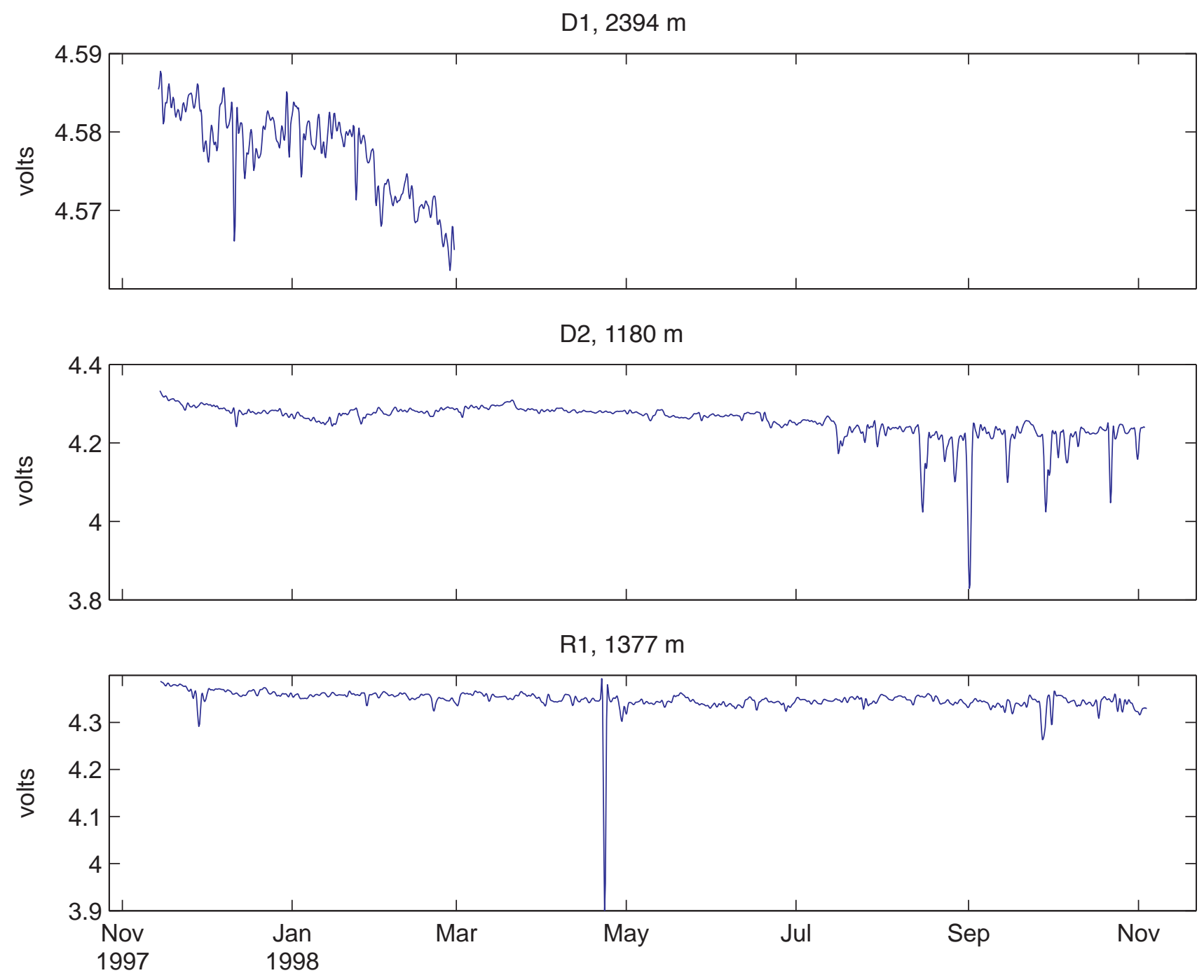

Figure E-3. Transmission plots at Moorings D1, D2, and R1. 
Appendix F.

Characteristics of tidal currents 
Table F-1. Characteristics of diurnal and semidiurnal tidal currents at Mooring D1.

\begin{tabular}{|c|c|c|c|c||}
\hline O1 & $\begin{array}{c}\text { Major } \\
\text { Amplitude } \\
(\mathbf{c m} / \mathbf{s})\end{array}$ & $\begin{array}{c}\text { Minor Amplitude } \\
(\mathbf{c m} / \mathbf{s})\end{array}$ & $\begin{array}{c}\text { Inclination } \\
\text { (degrees) }\end{array}$ & $\begin{array}{c}\text { Phase } \\
\text { (degrees) }\end{array}$ \\
\hline \hline 6 & 1.704 & 0.508 & 97.15 & 179.70 \\
\hline 10 & 1.704 & -0.313 & 92.25 & 163.31 \\
\hline 14 & 1.831 & -0.593 & 84.66 & 160.29 \\
\hline 18 & 1.767 & -0.614 & 80.32 & 162.10 \\
\hline 22 & 1.559 & -0.508 & 77.59 & 162.38 \\
\hline 26 & 1.393 & -0.412 & 78.01 & 155.98 \\
\hline 30 & 1.352 & -0.299 & 80.56 & 147.05 \\
\hline 34 & 1.347 & -0.204 & 83.90 & 142.97 \\
\hline 38 & 1.406 & -0.243 & 85.97 & 146.97 \\
\hline 42 & 1.535 & -0.314 & 85.13 & 150.28 \\
\hline 46 & 1.580 & -0.336 & 80.85 & 153.71 \\
\hline
\end{tabular}

\begin{tabular}{|c|c|c|c|c||}
\hline K1 & $\begin{array}{c}\text { Major } \\
\text { Amplitude } \\
\text { (cm/s) }\end{array}$ & $\begin{array}{c}\text { Minor Amplitude } \\
\text { (cm/s) }\end{array}$ & $\begin{array}{c}\text { Inclination } \\
\text { (degrees) }\end{array}$ & $\begin{array}{c}\text { Phase } \\
\text { (degrees) }\end{array}$ \\
\hline \hline 6 & 4.070 & 0.001 & 81.83 & 148.69 \\
\hline 10 & 2.935 & 0.792 & 81.11 & 150.70 \\
\hline 14 & 2.814 & -0.894 & 83.24 & 159.97 \\
\hline 18 & 2.976 & -0.966 & 88.18 & 165.12 \\
\hline 22 & 3.085 & -1.086 & 94.43 & 165.79 \\
\hline 26 & 3.203 & -1.167 & 00.26 & 166.19 \\
\hline 30 & 3.292 & -1.234 & 02.55 & 168.06 \\
\hline 34 & 3.274 & -1.229 & 02.16 & 171.51 \\
\hline 38 & 3.201 & -1.155 & 00.86 & 172.44 \\
\hline 42 & 3.144 & -1.086 & 99.59 & 172.73 \\
\hline 46 & 3.002 & -1.041 & 96.89 & 174.52 \\
\hline
\end{tabular}

\begin{tabular}{|c|c|c|c|c|}
\hline \hline M2 & $\begin{array}{c}\text { Major } \\
\text { Amplitude } \\
(\mathbf{c m} / \mathbf{s})\end{array}$ & $\begin{array}{c}\text { Minor Amplitude } \\
\text { (cm/s) }\end{array}$ & $\begin{array}{c}\text { Inclination } \\
\text { (degrees) }\end{array}$ & $\begin{array}{c}\text { Phase } \\
\text { (degrees) }\end{array}$ \\
\hline \hline 6 & 5.981 & -1.318 & 124.33 & 175.37 \\
\hline 10 & 4.468 & -1.403 & 119.32 & 174.23 \\
\hline 14 & 4.239 & -1.508 & 16.75 & 174.29 \\
\hline 18 & 4.133 & -1.584 & 14.91 & 175.07 \\
\hline 22 & 4.135 & -1.589 & 14.18 & 174.38 \\
\hline
\end{tabular}




\begin{tabular}{|l|l|l|l|l||}
\hline 26 & 4.160 & -1.553 & 14.16 & 174.11 \\
\hline 30 & 4.203 & -1.507 & 13.75 & 173.93 \\
\hline 34 & 4.181 & -1.508 & 13.75 & 173.56 \\
\hline 38 & 4.165 & -1.518 & 13.45 & 173.77 \\
\hline 42 & 4.182 & -1.488 & 13.52 & 174.62 \\
\hline 46 & 4.240 & -1.501 & 14.11 & 174.26 \\
\hline
\end{tabular}

\begin{tabular}{|c|c|c|c|c||}
\hline S2 & $\begin{array}{c}\text { Major } \\
\text { Amplitude } \\
(\mathbf{c m} / \mathbf{s})\end{array}$ & $\begin{array}{c}\text { Minor Amplitude } \\
(\mathbf{c m} / \mathbf{s})\end{array}$ & $\begin{array}{c}\text { Inclination } \\
\text { (degrees) }\end{array}$ & $\begin{array}{c}\text { Phase } \\
\text { (degrees) }\end{array}$ \\
\hline \hline 6 & 1.987 & -0.058 & 83.27 & 165.09 \\
\hline 10 & 2.130 & -0.402 & 63.40 & 153.54 \\
\hline 14 & 2.271 & -0.370 & 59.31 & 151.64 \\
\hline 18 & 2.304 & -0.486 & 56.82 & 154.76 \\
\hline 22 & 2.248 & -0.507 & 56.97 & 156.01 \\
\hline 26 & 2.262 & -0.493 & 58.20 & 155.95 \\
\hline 30 & 2.252 & -0.445 & 60.51 & 156.72 \\
\hline 34 & 2.176 & -0.391 & 63.35 & 157.33 \\
\hline 38 & 2.121 & -0.385 & 65.41 & 157.60 \\
\hline 42 & 2.079 & -0.371 & 67.34 & 156.01 \\
\hline 46 & 2.128 & -0.376 & 66.38 & 155.68 \\
\hline
\end{tabular}


Table F-2. Characteristics of diurnal and semidiurnal tidal currents at Mooring R1.

\begin{tabular}{|c|c|c|c|c|}
\hline \multicolumn{5}{|l|}{01} \\
\hline Depth (m) & $\begin{array}{c}\text { Major } \\
\text { Amplitude } \\
(\mathbf{c m} / \mathbf{s})\end{array}$ & $\begin{array}{c}\text { Minor } \\
\text { Amplitude } \\
(\mathbf{c m} / \mathbf{s})\end{array}$ & $\begin{array}{c}\text { Inclination } \\
\text { (degrees) }\end{array}$ & $\begin{array}{c}\text { Phase } \\
\text { (degrees) }\end{array}$ \\
\hline 4 & 1.720 & -0.003 & 134.18 & 198.34 \\
\hline 6 & 1.145 & 0.514 & 86.65 & 162.42 \\
\hline 8 & 1.297 & 0.048 & 111.16 & 152.15 \\
\hline 10 & 1.150 & -0.314 & 88.55 & 150.53 \\
\hline 12 & 1.101 & -0.265 & 87.27 & 146.99 \\
\hline 14 & 1.013 & -0.134 & 85.45 & 142.58 \\
\hline 16 & 0.937 & 0.012 & 89.08 & 137.87 \\
\hline 18 & 0.836 & 0.166 & 93.00 & 138.14 \\
\hline 20 & 0.803 & 0.233 & 97.11 & 143.90 \\
\hline 22 & 0.849 & 0.247 & 105.31 & 150.08 \\
\hline 24 & 0.907 & 0.212 & 108.27 & 155.90 \\
\hline 26 & 0.964 & 0.128 & 109.46 & 160.68 \\
\hline 28 & 0.981 & 0.073 & 110.50 & 162.72 \\
\hline 30 & 0.980 & -0.003 & 113.82 & 161.87 \\
\hline 32 & 0.950 & -0.089 & 116.69 & 159.18 \\
\hline 34 & 0.976 & -0.127 & 115.71 & 158.47 \\
\hline 36 & 1.014 & -0.160 & 116.46 & 157.25 \\
\hline 38 & 1.064 & -0.163 & 116.01 & 153.92 \\
\hline 40 & 1.140 & -0.172 & 115.69 & 148.59 \\
\hline 42 & 1.208 & -0.167 & 113.30 & 147.01 \\
\hline 44 & 1.211 & -0.157 & 110.74 & 145.53 \\
\hline 46 & 1.232 & -0.150 & 107.92 & 144.53 \\
\hline 48 & 1.257 & -0.160 & 106.00 & 142.28 \\
\hline 50 & 1.264 & -0.146 & 104.05 & 139.94 \\
\hline 52 & 1.242 & -0.107 & 101.58 & 139.46 \\
\hline 54 & 1.195 & -0.067 & 97.02 & 137.38 \\
\hline 56 & 1.151 & -0.027 & 92.51 & 135.37 \\
\hline 58 & 1.107 & 0.034 & 88.00 & 131.62 \\
\hline 60 & 1.051 & 0.092 & 82.41 & 125.78 \\
\hline 62 & 0.998 & 0.158 & 80.06 & 121.54 \\
\hline 64 & 0.980 & 0.260 & 79.02 & 116.70 \\
\hline 66 & 0.905 & 0.350 & 80.35 & 15.30 \\
\hline 68 & 0.911 & 0.388 & 85.37 & 19.57 \\
\hline 70 & 0.967 & 0.419 & 87.96 & 23.95 \\
\hline 72 & 1.009 & 0.395 & 95.88 & 32.84 \\
\hline 74 & 1.097 & 0.372 & 102.28 & 139.26 \\
\hline 76 & 1.143 & 0.303 & 104.88 & 143.75 \\
\hline 78 & 1.144 & 0.249 & 104.54 & 146.70 \\
\hline 80 & 1.106 & 0.205 & 104.11 & 148.66 \\
\hline 82 & 1.072 & 0.179 & 105.96 & 149.77 \\
\hline
\end{tabular}




\begin{tabular}{|c|c|c|c|c|}
\hline \multicolumn{5}{|l|}{$\overline{\mathbf{K} 1}$} \\
\hline Depth (m) & $\begin{array}{c}\text { Major } \\
\text { Amplitude } \\
(\mathbf{c m} / \mathbf{s})\end{array}$ & $\begin{array}{c}\text { Minor } \\
\text { Amplitude } \\
(\mathbf{c m} / \mathbf{s})\end{array}$ & $\begin{array}{c}\text { Inclination } \\
\text { (degrees) }\end{array}$ & $\begin{array}{c}\text { Phase } \\
\text { (degrees) }\end{array}$ \\
\hline 4 & 3.295 & 1.311 & 106.48 & 159.11 \\
\hline 6 & 1.906 & 1.387 & 55.47 & 122.30 \\
\hline 8 & 1.855 & 1.067 & 95.50 & 139.66 \\
\hline 10 & 1.781 & 0.591 & 79.70 & 134.73 \\
\hline 12 & 1.744 & 0.528 & 84.53 & 139.47 \\
\hline 14 & 1.721 & 0.502 & 88.03 & 144.38 \\
\hline 16 & 1.743 & 0.462 & 92.29 & 149.00 \\
\hline 18 & 1.720 & 0.371 & 94.99 & 152.85 \\
\hline 20 & 1.687 & 0.335 & 96.88 & 156.18 \\
\hline 22 & 1.665 & 0.337 & 101.51 & 158.67 \\
\hline 24 & 1.688 & 0.364 & 107.39 & 163.49 \\
\hline 26 & 1.747 & 0.315 & 113.09 & 168.71 \\
\hline 28 & 1.832 & 0.194 & 118.00 & 171.62 \\
\hline 30 & 1.979 & 0.045 & 119.55 & 173.29 \\
\hline 32 & 2.098 & -0.124 & 118.93 & 173.09 \\
\hline 34 & 2.188 & -0.238 & 118.86 & 171.67 \\
\hline 36 & 2.226 & -0.311 & 118.29 & 169.21 \\
\hline 38 & 2.215 & -0.408 & 117.63 & 166.39 \\
\hline 40 & 2.217 & -0.463 & 116.22 & 163.93 \\
\hline 42 & 2.227 & -0.439 & 115.13 & 162.24 \\
\hline 44 & 2.235 & -0.427 & 113.80 & 160.75 \\
\hline 46 & 2.255 & -0.370 & 112.13 & 158.83 \\
\hline 48 & 2.265 & -0.279 & 110.75 & 157.15 \\
\hline 50 & 2.244 & -0.187 & 110.13 & 156.02 \\
\hline 52 & 2.204 & -0.096 & 108.35 & 155.01 \\
\hline 54 & 2.133 & -0.040 & 107.37 & 155.06 \\
\hline 56 & 2.109 & -0.012 & 107.53 & 155.55 \\
\hline 58 & 2.089 & 0.003 & 108.43 & 155.94 \\
\hline 60 & 2.087 & 0.025 & 110.08 & 157.05 \\
\hline 62 & 2.059 & -0.001 & 110.57 & 158.48 \\
\hline 64 & 2.050 & -0.061 & 111.51 & 159.01 \\
\hline 66 & 2.005 & -0.077 & 112.11 & 160.54 \\
\hline 68 & 1.997 & -0.091 & 111.33 & 162.26 \\
\hline 70 & 1.995 & -0.065 & 111.09 & 163.60 \\
\hline 72 & 1.909 & -0.020 & 108.10 & 163.82 \\
\hline 74 & 1.801 & 0.046 & 106.13 & 162.56 \\
\hline 76 & 1.712 & 0.065 & 106.59 & 162.58 \\
\hline 78 & 1.708 & 0.024 & 108.25 & 163.36 \\
\hline 80 & 1.732 & 0.035 & 109.05 & 162.35 \\
\hline 82 & 1.782 & 0.016 & 109.81 & 163.15 \\
\hline
\end{tabular}




\begin{tabular}{|c|c|c|c|c|}
\hline M2 & $\begin{array}{c}\text { Major } \\
\text { Amplitude } \\
\text { (cm/s) }\end{array}$ & $\begin{array}{c}\text { Minor } \\
\text { Amplitude } \\
\text { (cm/s) }\end{array}$ & $\begin{array}{c}\text { Inclination } \\
\text { (degrees) }\end{array}$ & $\begin{array}{c}\text { Phase } \\
\text { (degrees) }\end{array}$ \\
\hline \hline 4 & 6.776 & -0.960 & 142.83 & 173.81 \\
\hline 6 & 6.652 & -1.385 & 132.50 & 164.96 \\
\hline 8 & 6.982 & -2.022 & 126.33 & 163.71 \\
\hline 10 & 6.581 & -2.257 & 122.22 & 163.81 \\
\hline 12 & 6.558 & -2.289 & 121.58 & 165.09 \\
\hline 14 & 6.484 & -2.338 & 121.60 & 165.29 \\
\hline 16 & 6.460 & -2.351 & 122.20 & 165.30 \\
\hline 18 & 6.455 & -2.401 & 122.74 & 164.72 \\
\hline 20 & 6.473 & -2.377 & 122.52 & 164.49 \\
\hline 22 & 6.492 & -2.352 & 122.67 & 164.22 \\
\hline 24 & 6.471 & -2.301 & 122.74 & 164.09 \\
\hline 26 & 6.437 & -2.233 & 123.25 & 164.08 \\
\hline 28 & 6.397 & -2.177 & 123.67 & 163.97 \\
\hline 30 & 6.378 & -2.160 & 124.03 & 164.03 \\
\hline 32 & 6.341 & -2.194 & 124.40 & 164.18 \\
\hline 34 & 6.343 & -2.220 & 124.70 & 164.53 \\
\hline 36 & 6.322 & -2.263 & 124.85 & 164.62 \\
\hline 38 & 6.311 & -2.264 & 124.57 & 164.65 \\
\hline 40 & 6.305 & -2.247 & 124.60 & 164.45 \\
\hline 42 & 6.311 & -2.241 & 124.56 & 164.60 \\
\hline 44 & 6.356 & -2.274 & 124.79 & 164.89 \\
\hline 46 & 6.403 & -2.318 & 125.08 & 165.07 \\
\hline 48 & 6.409 & -2.379 & 125.18 & 165.55 \\
\hline 50 & 6.448 & -2.417 & 125.43 & 165.88 \\
\hline 52 & 6.464 & -2.496 & 125.83 & 165.88 \\
\hline 54 & 6.495 & -2.536 & 126.13 & 166.35 \\
\hline 56 & 6.516 & -2.561 & 126.54 & 166.66 \\
\hline 58 & 6.516 & -2.595 & 127.15 & 166.89 \\
\hline 60 & 6.520 & -2.597 & 127.53 & 167.41 \\
\hline 62 & 6.532 & -2.597 & 128.11 & 167.59 \\
\hline 64 & 6.530 & -2.619 & 128.16 & 167.92 \\
\hline 66 & 6.555 & -2.634 & 128.33 & 168.24 \\
\hline 68 & 6.575 & -2.610 & 128.40 & 168.52 \\
\hline 70 & 6.597 & -2.581 & 128.73 & 168.45 \\
\hline 72 & 6.606 & -2.576 & 128.79 & 168.72 \\
\hline 74 & 6.599 & -2.600 & 128.78 & 168.99 \\
\hline 76 & 6.599 & -2.639 & 128.89 & 169.36 \\
\hline 80 & 6.607 & -2.667 & 128.61 & 169.65 \\
\hline 8.592 & 6.572 & -2.671 & 128.09 & 170.02 \\
\hline & & -2.657 & 127.96 & 170.17 \\
\hline
\end{tabular}




\begin{tabular}{|c|c|c|c|c|}
\hline \multicolumn{5}{|l|}{$\overline{\mathbf{S 2}}$} \\
\hline Depth (m) & $\begin{array}{c}\text { Major } \\
\text { Amplitude } \\
(\mathbf{c m} / \mathbf{s})\end{array}$ & $\begin{array}{c}\text { Minor } \\
\text { Amplitude } \\
(\mathbf{c m} / \mathbf{s})\end{array}$ & $\begin{array}{c}\text { Inclination } \\
\text { (degrees) }\end{array}$ & $\begin{array}{c}\text { Phase } \\
\text { (degrees) }\end{array}$ \\
\hline 4 & 2.254 & $\begin{array}{l}0.281 \\
\end{array}$ & 164.29 & 190.00 \\
\hline 6 & 1.637 & -0.197 & 129.20 & 201.87 \\
\hline 8 & 1.512 & 0.260 & 110.27 & 198.27 \\
\hline 10 & 1.413 & 0.506 & 102.86 & 197.91 \\
\hline 12 & 1.430 & 0.474 & 98.96 & 196.30 \\
\hline 14 & 1.470 & 0.446 & 100.15 & 198.50 \\
\hline 16 & 1.517 & 0.376 & 100.37 & 198.91 \\
\hline 18 & 1.523 & 0.356 & 100.69 & 200.22 \\
\hline 20 & 1.571 & 0.361 & 101.40 & 201.16 \\
\hline 22 & 1.589 & 0.329 & 102.82 & 201.43 \\
\hline 24 & 1.602 & 0.324 & 105.55 & 202.76 \\
\hline 26 & 1.613 & 0.310 & 106.72 & 202.54 \\
\hline 28 & 1.585 & 0.288 & 105.53 & 199.80 \\
\hline 30 & 1.573 & 0.265 & 104.41 & 198.26 \\
\hline 32 & 1.595 & 0.220 & 103.06 & 196.67 \\
\hline 34 & 1.622 & 0.201 & 103.54 & 195.26 \\
\hline 36 & 1.638 & 0.158 & 104.17 & 194.23 \\
\hline 38 & 1.690 & 0.094 & 106.12 & 194.04 \\
\hline 40 & 1.725 & 0.057 & 106.92 & 193.83 \\
\hline 42 & 1.797 & 0.035 & 108.32 & 194.72 \\
\hline 44 & 1.838 & 0.000 & 109.10 & 195.46 \\
\hline 46 & 1.893 & -0.037 & 110.42 & 197.42 \\
\hline 48 & 1.949 & -0.071 & 111.52 & 198.34 \\
\hline 50 & 1.983 & -0.065 & 111.94 & 198.38 \\
\hline 52 & 2.019 & -0.059 & 112.36 & 198.39 \\
\hline 54 & 2.039 & -0.069 & 112.23 & 198.00 \\
\hline 56 & 2.031 & -0.069 & 112.22 & 196.21 \\
\hline 58 & 2.047 & -0.071 & 112.80 & 194.82 \\
\hline 60 & 2.042 & -0.070 & 112.90 & 194.62 \\
\hline 62 & 2.016 & -0.064 & 113.85 & 195.28 \\
\hline 64 & 1.991 & -0.074 & 115.90 & 195.61 \\
\hline 66 & 1.952 & -0.087 & 117.13 & 196.37 \\
\hline 68 & 1.919 & -0.055 & 119.16 & 197.81 \\
\hline 70 & 1.917 & -0.038 & 121.54 & 199.09 \\
\hline 72 & 1.926 & -0.032 & 122.38 & 201.71 \\
\hline 74 & 1.906 & -0.032 & 124.23 & 203.31 \\
\hline 76 & 1.934 & -0.054 & 124.60 & 205.47 \\
\hline 78 & 1.919 & -0.063 & 125.26 & 206.60 \\
\hline 80 & 1.945 & -0.090 & 125.78 & 208.62 \\
\hline 82 & 1.955 & -0.122 & 127.13 & 210.01 \\
\hline
\end{tabular}


Appendix G.

Geochemistry of sediment-trap material and mussel tissue 
Table G-1. Environmental geochemistry of sediments ( $<63 \mathrm{~mm}$ fraction) recovered from mooring sediment traps. Total organic carbon (TOC) and total inorganic carbon (TIC) concentrations given in wt. \% dry sediment. Iron and aluminum concentrations given in $\mathrm{mg} / \mathrm{g}$ dry wt. sediment; all other trace metal concentrations expressed as $\mu \mathrm{g}$ metal/g dry wt. sediment. Elements marked with an asterisk (*) indicate analytical results that did not satisfy one or more QA/QC criteria.

\begin{tabular}{|c|c|c|c|c|c|c|}
\hline Sample & D1T-1 & D1M-1 & D1B-1 & D1B-2A & D1B-3 & D2T-1 \\
\hline $\begin{array}{c}\text { TOC } \\
\text { (wt. \%) } \\
\text { TIC }\end{array}$ & 2.36 & 2.34 & 2.53 & 2.38 & 2.50 & 4.83 \\
\hline (wt. \%) & 0.35 & 0.31 & 0.35 & 0.27 & 0.25 & 0.54 \\
\hline \multicolumn{7}{|l|}{ Element } \\
\hline $\mathrm{Al} *$ & $24.0 *$ & $15.0 *$ & $9.0 *$ & $25.0 *$ & $22.0 *$ & $8.0 *$ \\
\hline $\mathrm{Fe}^{*}$ & $31.6^{*}$ & $17.8^{*}$ & $21.2 *$ & $29.1 *$ & $29.0 *$ & $9.7 *$ \\
\hline $\mathrm{Ag}^{*}$ & $0.80 *$ & $0.54 *$ & $1.14 *$ & $1.14^{*}$ & $1.63 *$ & $0.41 *$ \\
\hline As & 6.76 & 6.33 & 5.05 & 6.68 & 5.66 & 4.67 \\
\hline $\mathrm{Au}^{*}$ & $0.12 *$ & $0.14 *$ & $0.13 *$ & $0.13^{*}$ & $0.10^{*}$ & $0.13 *$ \\
\hline $\mathrm{Ba}^{*}$ & $134 *$ & $161 *$ & $386^{*}$ & $308 *$ & $367 *$ & $153 *$ \\
\hline $\mathrm{Cd}$ & 1.91 & 1.19 & 0.51 & 0.71 & 0.39 & 1.76 \\
\hline $\mathrm{Co}$ & 12.71 & 9.48 & 6.60 & 10.01 & 8.93 & 3.25 \\
\hline $\mathrm{Cr} *$ & $80.59 *$ & $51.84 *$ & $63.27 *$ & $81.32 *$ & $79.22 *$ & $26.65 *$ \\
\hline $\mathrm{Cu}^{*}$ & $43.29 *$ & $25.53^{*}$ & $48.37 *$ & $40.54 *$ & $44.01 *$ & $54.66^{*}$ \\
\hline $\mathrm{Hg}^{*}$ & $0.40 *$ & $0.28 *$ & $0.28 *$ & $0.30 *$ & $0.28 *$ & $0.20 *$ \\
\hline $\mathrm{Mn}$ & 305 & 155 & 184 & 280 & 254 & 95 \\
\hline Mo* & $2.15^{*}$ & $1.30 *$ & $0.68 *$ & $0.51 *$ & $0.46^{*}$ & $0.76^{*}$ \\
\hline $\mathrm{Ni}^{*}$ & 79.53 & 47.78 & 59.30 & 75.33 & 75.87 & 27.70 \\
\hline $\mathrm{Pb}$ & 23.81 & 13.27 & 8.71 & 13.86 & 11.59 & 6.66 \\
\hline $\mathrm{Sc}^{*}$ & $12.58 *$ & $9.40 *$ & $9.83 *$ & $11.18 *$ & $10.01 *$ & $8.66 *$ \\
\hline $\mathrm{Se}^{*}$ & $26.26^{*}$ & $54.92 *$ & $48.08 *$ & $40.75^{*}$ & $45.77 *$ & $92.45^{*}$ \\
\hline $\mathrm{Sn}^{*}$ & $1.26^{*}$ & $1.51 *$ & $1.20 *$ & $1.07 *$ & $1.13 *$ & $0.67 *$ \\
\hline Sr* & $119 *$ & $175^{*}$ & $154 *$ & $110 *$ & $103^{*}$ & $268 *$ \\
\hline $\mathrm{Ti}^{*}$ & $383 *$ & $335 *$ & $408 *$ & $443 *$ & $380 *$ & $185^{*}$ \\
\hline $\mathrm{U}^{*}$ & $1.54 *$ & $0.83^{*}$ & $1.15^{*}$ & $1.17 *$ & $1.19 *$ & $0.41 *$ \\
\hline $\mathrm{V}^{*}$ & $61.82 *$ & $40.63^{*}$ & $41.51 *$ & $54.55 *$ & $47.19 *$ & $22.92 *$ \\
\hline $\mathrm{Zn}$ & 136 & 77 & 416 & 104 & 109 & 63 \\
\hline
\end{tabular}


Table G-2. Trace metal concentrations in mussel tissue from mussels deployed with moorings. All concentrations expressed as $\mu \mathrm{g}$ metal/g dry wt. tissue.

\begin{tabular}{|c|rcrrrrrrrrrrrr||}
\hline \multirow{3}{*}{ Station } & Element & Ag & Al & As & Cd & Cu & Cr & Hg & Mn & Ni & Pb & Se & Sn & Zn \\
& & & & & & & & & & & & & \\
\hline \multirow{2}{*}{ D1 } & replicate 1 & 0.115 & 92 & 12.5 & 13.2 & 3.94 & 2.61 & 0.265 & 3.60 & 2.78 & 1.59 & 3.37 & 0.033 & 177 \\
& replicate 2 & 0.142 & 107 & 11.9 & 14.8 & 4.52 & 2.96 & 0.256 & 4.12 & 3.03 & 1.79 & 3.44 & 0.055 & 196 \\
& replicate 3 & 0.133 & 181 & 12.6 & 17.0 & 4.35 & 3.19 & 0.297 & 6.58 & 3.56 & 2.02 & 3.89 & 0.118 & 193 \\
& MEAN: & $\mathbf{0 . 1 3 0}$ & $\mathbf{1 2 7}$ & $\mathbf{1 2 . 3}$ & $\mathbf{1 5 . 0}$ & $\mathbf{4 . 2 7}$ & $\mathbf{2 . 9 2}$ & $\mathbf{0 . 2 7 3}$ & $\mathbf{4 . 7 7}$ & $\mathbf{3 . 1 2}$ & $\mathbf{1 . 8 0}$ & $\mathbf{3 . 5 7}$ & $\mathbf{0 . 0 6 9}$ & $\mathbf{1 8 9}$ \\
& STDV: & $\mathbf{0 . 0 1 4}$ & $\mathbf{4 8}$ & $\mathbf{0 . 4}$ & $\mathbf{1 . 9}$ & $\mathbf{0 . 3 0}$ & $\mathbf{0 . 2 9}$ & $\mathbf{0 . 0 2 2}$ & $\mathbf{1 . 5 9}$ & $\mathbf{0 . 4 0}$ & $\mathbf{0 . 2 2}$ & $\mathbf{0 . 2 8}$ & $\mathbf{0 . 0 4 4}$ & $\mathbf{1 0}$ \\
\hline \multirow{2}{*}{ D2 } & replicate 1 & 0.138 & 156 & 12.9 & 20.0 & 4.05 & 2.92 & 0.316 & 3.00 & 3.53 & 1.96 & 3.27 & 0.036 & 190 \\
& replicate 2 & 0.111 & 125 & 11.2 & 14.2 & 3.95 & 2.77 & 0.230 & 2.80 & 2.84 & 1.42 & 3.02 & 0.034 & 178 \\
& replicate 3 & 0.130 & 183 & 11.4 & 13.9 & 4.24 & 2.76 & 0.237 & 3.86 & 3.54 & 1.69 & 3.21 & 0.051 & 188 \\
& MEAN: & $\mathbf{0 . 1 2 6}$ & $\mathbf{1 5 5}$ & $\mathbf{1 1 . 8}$ & $\mathbf{1 6 . 0}$ & $\mathbf{4 . 0 8}$ & $\mathbf{2 . 8 2}$ & $\mathbf{0 . 2 6 1}$ & $\mathbf{3 . 2 2}$ & $\mathbf{3 . 3 0}$ & $\mathbf{1 . 6 9}$ & $\mathbf{3 . 1 7}$ & $\mathbf{0 . 0 4 0}$ & $\mathbf{1 8 5}$ \\
& STDV: & $\mathbf{0 . 0 1 4}$ & $\mathbf{2 9}$ & $\mathbf{0 . 9}$ & $\mathbf{3 . 4}$ & $\mathbf{0 . 1 5}$ & $\mathbf{0 . 0 9}$ & $\mathbf{0 . 0 4 8}$ & $\mathbf{0 . 5 6}$ & $\mathbf{0 . 4 0}$ & $\mathbf{0 . 2 7}$ & $\mathbf{0 . 1 3}$ & $\mathbf{0 . 0 0 9}$ & $\mathbf{6}$ \\
\hline R1 & replicate 1 & 0.114 & 33 & 11.3 & 15.1 & 3.68 & 2.65 & 0.261 & 1.78 & 2.30 & 1.40 & 2.32 & 0.011 & 180 \\
& replicate 2 & 0.186 & 62 & 11.0 & 13.4 & 4.55 & 2.41 & 0.321 & 2.71 & 2.53 & 1.75 & 3.14 & 0.004 & 188 \\
& replicate 3 & 0.127 & 65 & 12.5 & 18.6 & 3.96 & 2.95 & 0.344 & 2.77 & 2.99 & 1.98 & 2.96 & 0.003 & 231 \\
& MEAN: & $\mathbf{0 . 1 4 2}$ & $\mathbf{5 3}$ & $\mathbf{1 1 . 6}$ & $\mathbf{1 5 . 7}$ & $\mathbf{4 . 0 6}$ & $\mathbf{2 . 6 7}$ & $\mathbf{0 . 3 0 9}$ & $\mathbf{2 . 4 2}$ & $\mathbf{2 . 6 1}$ & $\mathbf{1 . 7 1}$ & $\mathbf{2 . 8 1}$ & $\mathbf{0 . 0 0 6}$ & $\mathbf{2 0 0}$ \\
& STDV: & $\mathbf{0 . 0 3 8}$ & $\mathbf{1 8}$ & $\mathbf{0 . 8}$ & $\mathbf{2 . 7}$ & $\mathbf{0 . 4 4}$ & $\mathbf{0 . 2 7}$ & $\mathbf{0 . 0 4 3}$ & $\mathbf{0 . 5 6}$ & $\mathbf{0 . 3 5}$ & $\mathbf{0 . 2 9}$ & $\mathbf{0 . 4 3}$ & $\mathbf{0 . 0 0 4}$ & $\mathbf{2 7}$ \\
\hline
\end{tabular}


Table G-3. Results of polycyclic aromatic hydrocarbon (PAH) analyses for mussel tissue from mussels deployed with moorings. All concentrations expressed as ng PAH/g dry wt. tissue. Moisture content is given in wt.\%.

\begin{tabular}{|c|c|c|c|c|c|c|c|c|c|c|c|c|c|c|}
\hline \multirow[b]{3}{*}{ Analyte: } & \multirow{2}{*}{$\begin{array}{c}\text { Reporting } \\
\text { Limit }\end{array}$} & \multirow{2}{*}{$\begin{array}{c}\text { Method } \\
\text { Blank }\end{array}$} & \multicolumn{3}{|c|}{ D1 } & \multicolumn{3}{|c|}{ D2 } & \multicolumn{4}{|c|}{$\mathbf{R 1}$} & \multirow{2}{*}{$\begin{array}{c}\text { Reporting } \\
\text { Limit }\end{array}$} & \multirow{2}{*}{$\begin{array}{l}\text { Methoc } \\
\text { Blank }\end{array}$} \\
\hline & & & rep 1 & rep2 & rep3 & rep 1 & rep2 & rep3 & rep1 & rep2 & rep2dup & rep3 & & \\
\hline & dry wt. & dry wt. & dry wt. & $\begin{array}{l}\text { dry } \\
\text { wt. }\end{array}$ & $\begin{array}{l}\text { dry } \\
\text { wt. }\end{array}$ & dry wt. & $\begin{array}{l}\text { dry } \\
\text { wt. }\end{array}$ & $\begin{array}{l}\text { dry } \\
\text { wt. }\end{array}$ & dry wt. & $\begin{array}{l}\text { dry } \\
\text { wt. }\end{array}$ & dry wt. & $\begin{array}{l}\text { dry } \\
\text { wt. }\end{array}$ & fresh wt. & $\begin{array}{c}\text { fresh } \\
\text { wt. }\end{array}$ \\
\hline naphthalene & 10 & $<\mathrm{RL}$ & $<\mathrm{RL}$ & $<\mathrm{RL}$ & $<\mathrm{RL}$ & $<\mathrm{RL}$ & $<\mathrm{RL}$ & $<\mathrm{RL}$ & $<\mathrm{RL}$ & $<\mathrm{RL}$ & $<\mathrm{RL}$ & $<\mathrm{RL}$ & 1.11 & 10 \\
\hline 2-methylnaphthalene & 10 & $<\mathrm{RL}$ & $<\mathrm{RL}$ & $<\mathrm{RL}$ & $<\mathrm{RL}$ & $<\mathrm{RL}$ & $<\mathrm{RL}$ & $<\mathrm{RL}$ & $<\mathrm{RL}$ & $<\mathrm{RL}$ & $<\mathrm{RL}$ & $<\mathrm{RL}$ & 0.53 & 10 \\
\hline 1-methylnaphthalene & 10 & $<\mathrm{RL}$ & $<\mathrm{RL}$ & $<\mathrm{RL}$ & $<\mathrm{RL}$ & $<\mathrm{RL}$ & $<\mathrm{RL}$ & $<\mathrm{RL}$ & $<\mathrm{RL}$ & $<\mathrm{RL}$ & $<\mathrm{RL}$ & $<\mathrm{RL}$ & 0.73 & 10 \\
\hline biphenyl & 10 & $<\mathrm{RL}$ & $<\mathrm{RL}$ & $<\mathrm{RL}$ & $<\mathrm{RL}$ & $<\mathrm{RL}$ & $<\mathrm{RL}$ & $<\mathrm{RL}$ & $<\mathrm{RL}$ & $<\mathrm{RL}$ & $<\mathrm{RL}$ & $<\mathrm{RL}$ & 1.55 & 10 \\
\hline 2,6-dimethylnaphthalene & 10 & $<\mathrm{RL}$ & $<\mathrm{RL}$ & $<\mathrm{RL}$ & $<\mathrm{RL}$ & $<\mathrm{RL}$ & $<\mathrm{RL}$ & $<\mathrm{RL}$ & $<\mathrm{RL}$ & $<\mathrm{RL}$ & $<\mathrm{RL}$ & $<\mathrm{RL}$ & 0.94 & 10 \\
\hline acenaphthylene & 10 & $<\mathrm{RL}$ & $<\mathrm{RL}$ & $<\mathrm{RL}$ & $<\mathrm{RL}$ & $<\mathrm{RL}$ & $<\mathrm{RL}$ & $<\mathrm{RL}$ & $<\mathrm{RL}$ & $<\mathrm{RL}$ & $<\mathrm{RL}$ & $<\mathrm{RL}$ & 0.00 & 10 \\
\hline acenaphthene & 10 & $<\mathrm{RL}$ & $<\mathrm{RL}$ & $<\mathrm{RL}$ & $<\mathrm{RL}$ & $<\mathrm{RL}$ & $<\mathrm{RL}$ & $<\mathrm{RL}$ & $<\mathrm{RL}$ & $<\mathrm{RL}$ & $<\mathrm{RL}$ & $<\mathrm{RL}$ & 1.24 & 10 \\
\hline 2,3,5-trimethylnaphthalene & 10 & $<\mathrm{RL}$ & $<\mathrm{RL}$ & $<\mathrm{RL}$ & $<\mathrm{RL}$ & $<\mathrm{RL}$ & $<\mathrm{RL}$ & $<\mathrm{RL}$ & $<\mathrm{RL}$ & $<\mathrm{RL}$ & $<\mathrm{RL}$ & $<\mathrm{RL}$ & 1.13 & 10 \\
\hline fluorene & 10 & $<\mathrm{RL}$ & $<\mathrm{RL}$ & $<\mathrm{RL}$ & $<\mathrm{RL}$ & $<\mathrm{RL}$ & $<\mathrm{RL}$ & $<\mathrm{RL}$ & $<\mathrm{RL}$ & $<\mathrm{RL}$ & $<\mathrm{RL}$ & $<\mathrm{RL}$ & 0.49 & 10 \\
\hline phenanthrene & 10 & $<\mathrm{RL}$ & $<\mathrm{RL}$ & $<\mathrm{RL}$ & $<\mathrm{RL}$ & $<\mathrm{RL}$ & $<\mathrm{RL}$ & $<\mathrm{RL}$ & $<\mathrm{RL}$ & $<\mathrm{RL}$ & $<\mathrm{RL}$ & $<\mathrm{RL}$ & 0.61 & 10 \\
\hline anthracene & 10 & $<\mathrm{RL}$ & $<\mathrm{RL}$ & $<\mathrm{RL}$ & $<\mathrm{RL}$ & $<\mathrm{RL}$ & $<\mathrm{RL}$ & $<\mathrm{RL}$ & $<\mathrm{RL}$ & $<\mathrm{RL}$ & $<\mathrm{RL}$ & $<\mathrm{RL}$ & 0.88 & 10 \\
\hline 1-methylphenanthrene & 10 & $<\mathrm{RL}$ & $<\mathrm{RL}$ & $<\mathrm{RL}$ & $<\mathrm{RL}$ & $<\mathrm{RL}$ & $<\mathrm{RL}$ & $<\mathrm{RL}$ & $<\mathrm{RL}$ & $<\mathrm{RL}$ & $<\mathrm{RL}$ & $<\mathrm{RL}$ & 0.78 & 10 \\
\hline fluoranthene & 10 & $<\mathrm{RL}$ & $<\mathrm{RL}$ & $<\mathrm{RL}$ & $<\mathrm{RL}$ & $<\mathrm{RL}$ & $<\mathrm{RL}$ & $<\mathrm{RL}$ & $<\mathrm{RL}$ & $<\mathrm{RL}$ & $<\mathrm{RL}$ & $<\mathrm{RL}$ & 0.88 & 10 \\
\hline pyrene & 10 & $<\mathrm{RL}$ & $<\mathrm{RL}$ & $<\mathrm{RL}$ & $<\mathrm{RL}$ & $<\mathrm{RL}$ & $<\mathrm{RL}$ & $<\mathrm{RL}$ & $<\mathrm{RL}$ & $<\mathrm{RL}$ & $<\mathrm{RL}$ & $<\mathrm{RL}$ & 1.07 & 10 \\
\hline benz[a]anthracene & 10 & $<\mathrm{RL}$ & $<\mathrm{RL}$ & $<\mathrm{RL}$ & $<\mathrm{RL}$ & $<\mathrm{RL}$ & $<\mathrm{RL}$ & $<\mathrm{RL}$ & $<\mathrm{RL}$ & $<\mathrm{RL}$ & $<\mathrm{RL}$ & $<\mathrm{RL}$ & 0.05 & 10 \\
\hline chrysene & 10 & $<\mathrm{RL}$ & $<\mathrm{RL}$ & $<\mathrm{RL}$ & $<\mathrm{RL}$ & $<\mathrm{RL}$ & $<\mathrm{RL}$ & $<\mathrm{RL}$ & $<\mathrm{RL}$ & $<\mathrm{RL}$ & $<\mathrm{RL}$ & $<\mathrm{RL}$ & 0.00 & 10 \\
\hline benzo[b]fluoranthene & 10 & $<\mathrm{RL}$ & $<\mathrm{RL}$ & $<\mathrm{RL}$ & $<\mathrm{RL}$ & $<\mathrm{RL}$ & $<\mathrm{RL}$ & $<\mathrm{RL}$ & $<\mathrm{RL}$ & $<\mathrm{RL}$ & $<\mathrm{RL}$ & $<\mathrm{RL}$ & 0.14 & 10 \\
\hline benzo[k]fluoranthene & 10 & $<\mathrm{RL}$ & $<\mathrm{RL}$ & $<\mathrm{RL}$ & $<\mathrm{RL}$ & $<\mathrm{RL}$ & $<\mathrm{RL}$ & $<\mathrm{RL}$ & $<\mathrm{RL}$ & $<\mathrm{RL}$ & $<\mathrm{RL}$ & $<\mathrm{RL}$ & 0.11 & 10 \\
\hline benzo[e]pyrene & 10 & $<\mathrm{RL}$ & $<\mathrm{RL}$ & $<\mathrm{RL}$ & $<\mathrm{RL}$ & $<\mathrm{RL}$ & $<\mathrm{RL}$ & $<\mathrm{RL}$ & $<\mathrm{RL}$ & $<\mathrm{RL}$ & $<\mathrm{RL}$ & $<\mathrm{RL}$ & 0.60 & 10 \\
\hline benzo[a]pyrene & 10 & $<\mathrm{RL}$ & $<\mathrm{RL}$ & $<\mathrm{RL}$ & $<\mathrm{RL}$ & $<\mathrm{RL}$ & $<\mathrm{RL}$ & $<\mathrm{RL}$ & $<\mathrm{RL}$ & $<\mathrm{RL}$ & $<\mathrm{RL}$ & $<\mathrm{RL}$ & 0.00 & 10 \\
\hline perylene & 10 & $<\mathrm{RL}$ & $<\mathrm{RL}$ & $<\mathrm{RL}$ & $<\mathrm{RL}$ & $<\mathrm{RL}$ & $<\mathrm{RL}$ & $<\mathrm{RL}$ & $<\mathrm{RL}$ & $<\mathrm{RL}$ & $<\mathrm{RL}$ & $<\mathrm{RL}$ & 1.78 & 10 \\
\hline indeno[1,2,3-cd]pyrene & 10 & $<\mathrm{RL}$ & $<\mathrm{RL}$ & $<\mathrm{RL}$ & $<\mathrm{RL}$ & $<\mathrm{RL}$ & $<\mathrm{RL}$ & $<\mathrm{RL}$ & $<\mathrm{RL}$ & $<\mathrm{RL}$ & $<\mathrm{RL}$ & $<\mathrm{RL}$ & 3.94 & 10 \\
\hline dibenz[a,h]anthracene & 10 & $<\mathrm{RL}$ & $<\mathrm{RL}$ & $<\mathrm{RL}$ & $<\mathrm{RL}$ & $<\mathrm{RL}$ & $<\mathrm{RL}$ & $<\mathrm{RL}$ & $<\mathrm{RL}$ & $<\mathrm{RL}$ & $<\mathrm{RL}$ & $<\mathrm{RL}$ & 3.73 & 10 \\
\hline benzo[ghi]perylene & 10 & $<\mathrm{RL}$ & $<\mathrm{RL}$ & $<\mathrm{RL}$ & $<\mathrm{RL}$ & $<\mathrm{RL}$ & $<\mathrm{RL}$ & $<\mathrm{RL}$ & $<\mathrm{RL}$ & $<\mathrm{RL}$ & $<\mathrm{RL}$ & $<\mathrm{RL}$ & 3.90 & 10 \\
\hline Percent Moisture: & & & 88.3 & 88.0 & 88.0 & 87.9 & 88.5 & 87.7 & 87.9 & 88.6 & 88.6 & 87.5 & & \\
\hline
\end{tabular}




\section{Appendix $\mathbf{H}$.}

Farallon Islands sediment-trap samples-

Quality Assurance/Quality Control (QA/QC) Report 


\section{Definition of terms}

Acid-cleaned: Objects cleaned with $10 \%(\mathrm{v} / \mathrm{v})$ hydrochloric acid followed by three rinses with DDW and then dried in a forced-air convection oven

Acid-rinsed: $\quad$ Objects soaked in 10\% (v/v) nitric acid, then rinsed three times with DDW and stored in DDW

Acid-washed: Objects subjected to a minimum 12-hour soak in $10 \%(\mathrm{v} / \mathrm{v})$ hydrochloric acid at $20^{\circ} \mathrm{C}$; followed by three successive rinses with DDW followed by a minimum 12-hour soak in DDW, followed by a 24-hour drying period under a clean hood

DCM: Dichloromethane (aka methylene chloride)

DDW: Distilled, deionized water

MDL: Method detection limit; defined as 3.143 times the standard deviation of seven replicate analyses of representative blanks

NIST: National Institute of Standards and Technology

SRM: Standard Reference Material

Reporting limit: One-half the concentration of the lowest calibration standard

RSD: Relative standard deviation 


\section{PROBLEM DEFINITION/BACKGROUND}

The waterways of San Francisco Bay require periodic dredging to remain navigable by ocean-going vessels. Dredged material is disposed of at an offshore, deep-water site offshore of the bounds of the Gulf of the Farallones National Marine Sanctuary. Concerns regarding the fate and transport of this dredged material have prompted this study into the sedimentation patterns and geochemical cycling of trace metals and organic contaminants in the vicinity of the disposal area and sanctuary.

One of the goals of this study is to set up sediment traps in trafficked areas to monitor sediment accumulation patterns. The environmental geochemistry (trace-metal content) of accumulating material has been studied and compared to the chemical signature of dredged material to determine if they are similar and if the accumulating material exceeds threshold criteria. Mussels were deployed with the moorings to monitor for bioavailable contamination and analyzed for metals and PAHs.

\section{MEASUREMENT/DATA ACQUISITION}

\section{Sampling methods requirements}

Sediment-trap deployment:

Sediment traps were deployed for in situ collection of sediment from the water column. Sediment traps collected samples in clean, plastic core tubes; sodium azide was added to the traps to halt microbial activity. Clean Teflon® beads were added (automatically) to the sedimenttrap collection tubes to mark time horizons within the accumulated material. After retrieval, the tubes were stoppered with plastic caps, sealed with black tape, and stored at $4{ }^{\circ} \mathrm{C}$ until the sediment cores within the tubes could be sectioned.

Sediment-trap sampling:

During sectioning, standing water was first drained from the core tube and the remaining sediment was physically extruded. Personnel wore vinyl gloves during the transfer. Teflon® spatulas were used to transfer sediment from the core tube to certified-clean (suitable for tracemetal and semivolatile analysis) glass jars. Typically, one sample was collected per core tube. Multiple samples (reflecting different time horizons) were taken from a single core tube if and only if discrete layers of Teflon ${ }^{\circledR}$ beads could clearly be distinguished (by visual inspection). Jars of sediment samples were then frozen.

\section{Sample handling requirements}

Sample preparation

Frozen sediment samples were first thawed and then homogenized with a Teflon ${ }^{\circledR}$ spatula. Homogenized sediment was then wet sieved (using DDW) through acid-washed 0.63 mm plastic mesh into an acid-washed glass beaker (in order to physically separate sediment from the Teflon ${ }^{\circledR}$ beads). Sieved material was then dried in a forced-air convection oven at $40^{\circ} \mathrm{C}$. After 
material was completely dried (verified by constant mass), sediment was ground using an acidcleaned ceramic mortar and pestle. Ground material was stored in acid-washed polypropylene bottles.

Sediment digestion

Sediment digestion was conducted using a modified version of EPA Method 3051, "Microwave-Assisted Acid Digestion of Sediments, Sludges, Soils and Oils.” In this study, approximately $0.500 \mathrm{~g}$ of dried sediment was weighed out into a fluorocarbon digestion vessel. $10 \mathrm{~mL}$ of concentrated (70\%) trace-metal-grade nitric acid was added to the sediment. The digestion vessel was capped, placed in a laboratory microwave unit (CEM-81D), and heated. Pre- and post-digestion vessel weights were measured (to $0.001 \mathrm{~g}$ ) to monitor for any sample loss during heating. Samples were cooled and then diluted with $20 \mathrm{~mL}$ of DDW. The diluted digestate was subsequently filtered through acid-rinsed polycarbonate $(0.4 \mathrm{~mm})$ filters and stored at $20^{\circ} \mathrm{C}$ in acid-washed polypropylene plastic bottles until analysis. Digestates were analyzed within 21 days after preparation.

\section{Digestate analysis}

(Modified from EPA Method 6020, “Inductively Coupled Plasma-Mass Spectrometry”)

Calibration standards and blanks were prepared fresh daily from certified stock solutions under a Class 100 laminar flow hood. Five-point calibration curves were generated for each analyte. Standards and samples alike were spiked with an internal standard (10 ppb each of In and $\mathrm{Bi}$ ). All samples and standards were prepared such that the final concentration of nitric acid was 5.8\% (v/v). A rinse blank, prepared from trace metal-free nitric acid, was used to flush the system between each analysis to reduce memory effects.

Laboratory QC Requirements

Contamination

Laboratory:

Only plastic, glass, or Teflon ${ }^{\circledR}$ materials were allowed to contact the samples. All materials coming into contact with sediment and/or digestates were first acid-washed. Vinyl gloves were worn at all times during sample preparation/extraction.

Digestion:

One preparation blank was processed during each microwave-digestion run to monitor for contamination. Preparation blanks were considered to pass if an analyte's concentration was below its MDL.

\section{Precision}

Digestion:

Subsplits, three aliquots of homogenized sediment, were prepared for each sample set ( 5\% of total samples) and treated as individual samples. Subsplits were considered to pass if the RSD of the mean analyte concentration was less than $15 \%$. 
ICP-MS Analyses:

Three separate aliquots were prepared from a single diluted digestate and analyzed as individual samples. The aliquots were considered to pass if the RSD of the mean analyte concentration was less than $15 \%$.

Accuracy

Digestion:

Pre- and post-digestion vessel weights were measured to monitor for any sample loss during heating.

One aliquot of SRM 2704 (Buffalo River Sediment- NIST) was digested with every sample set to monitor for completeness of digestion. SRM aliquots were deemed acceptable if the metal recovery, $\mathrm{R}$, was within $20 \%$ of certified values.

ICP-MS analyses:

Accuracy of the calibration curve was checked by analyzing an aliquot of SRM 1643d (Trace Metals in Water-NIST). SRM aliquots were deemed acceptable if the metal concentration, C, was within $20 \%$ of certified values. 